\title{
Aging Gracefully in the Renaissance
}




\title{
Medieval and Renaissance Authors and Texts
}

\author{
Editor-in-Chief \\ Francis G. Gentry \\ Emeritus Professor of German, Penn State University
}

\begin{abstract}
Editorial Board
Teodolinda Barolini, Columbia University

Cynthia Brown, University of California, Santa Barbara

Marina Brownlee, Princeton University

Keith Busby, University of Wisconsin-Madison

Craig Kallendorf, Texas A\&M University

Alastair Minnis, Yale University

Brian Murdoch, Stirling University

Jan Ziolkowski, Harvard University and Dumbarton Oaks

Research Library and Collection
\end{abstract}

VOLUME 11

The titles published in this series are listed at brill.com/mrat 
Cynthia Skenazi - 978-90-04-25572-2 Downloaded from Brill.com04/26/2023 02:43:17PM via free access 


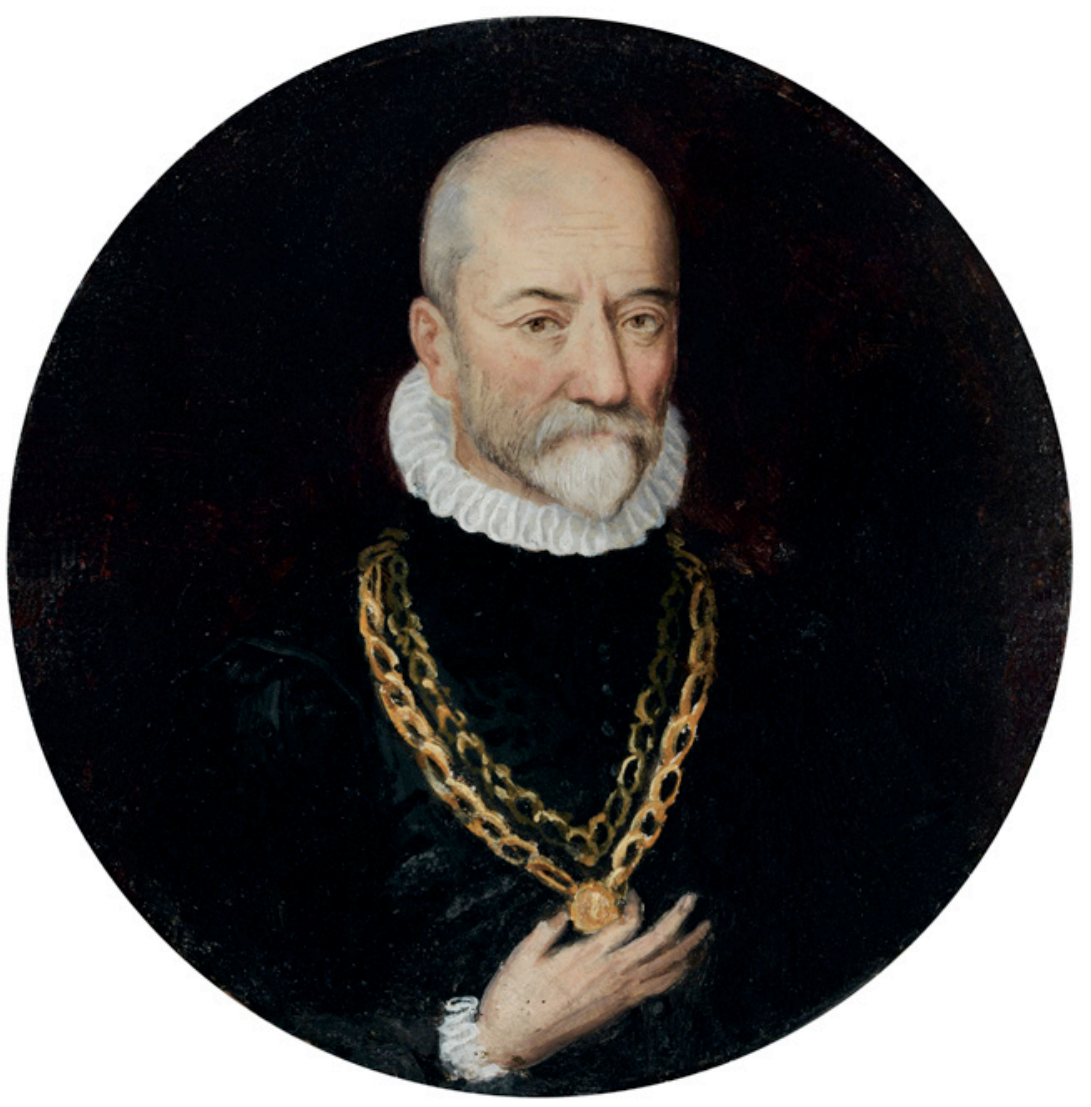

Portrait of Montaigne. French School, circa 1590.

(From Philippe Desan. Portraits à l'essai. Iconographie de Montaigne.

Etudes montaignistes 50. Paris: Champion, 2007, p. 70.)

Private Collection. Courtesy Philippe Desan. 


\section{Aging Gracefully in the Renaissance}

Stories of Later Life from Petrarch to Montaigne

By

Cynthia Skenazi

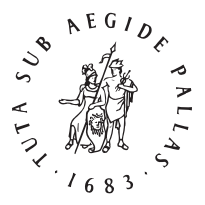

B R I L L

LEIDEN • BOSTON

2013 
B R I L L This is an open access title distributed under the terms of the Creative Commons

O P E N Attribution-Noncommercial-NonDerivative 3.0 Unported (CC-BY-NC-ND 3.0) License, which permits any non-commercial use, and distribution, provided no alterations are made and the original author(s) and source are credited.

This publication has been typeset in the multilingual "Brill" typeface. With over 5,100 characters covering Latin, IPA, Greek, and Cyrillic, this typeface is especially suitable for use in the humanities. For more information, please see www.brill.com/brill-typeface.

ISSN 0925-7683

ISBN 978-90-04-25466-4 (hardback)

ISBN 978-90-04-25572-2 (e-book)

Copyright 2013 by Cynthia Skenazi.

This work is published by Koninklijke Brill NV. Koninklijke Brill NV incorporates the imprints Brill, Brill Nijhoff, Global Oriental and Hotei Publishing.

Koninklijke Brill NV reserves the right to protect the publication against unauthorized use and to authorize dissemination by means of offprints, legitimate photocopies, microform editions, reprints, translations, and secondary information sources, such as abstracting and indexing services including databases. Requests for commercial re-use, use of parts of the publication, and/or translations must be addressed to Koninklijke Brill NV.

This book is printed on acid-free paper. 
In memory of my parents 
Cynthia Skenazi - 978-90-04-25572-2 Downloaded from Brill.com04/26/2023 02:43:17PM via free access 


\section{CONTENTS}

Acknowledgments ............................................................................... ix

Abbreviations ............................................................................................... xi

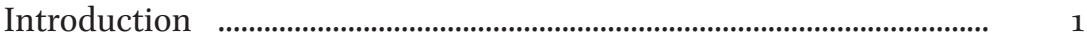

$1 \quad$ A Sound Mind in a Healthy Body ........................................................ $\quad 15$

Galen ....................................................................................................... 17

Petrarch ................................................................................... 22

Ficino and Zerbi .......................................................................... $\quad 28$

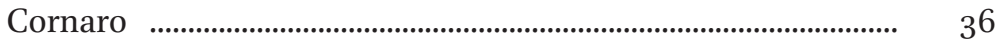

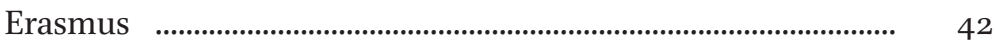

Montaigne .......................................................................................... 47

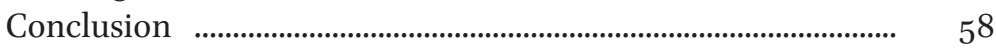

2 The Circulation of Power and Knowledge ....................................... 61

Petrarch ...................................................................................... 64

Castiglione .................................................................................. $\quad 79$

Montaigne ....................................................................................... 86

Conclusion .............................................................................................. 95

3 Love in Old Age ................................................................................ 98

Petrarch ...................................................................................... 100

Ronsard .......................................................................................... 105

Montaigne ..................................................................................... 111

Pasquier .................................................................................... 119

Conclusion ...................................................................................... 136

$4 \quad$ Then and Now ............................................................................................. 138

The Care of the Aging Self .......................................................... 139

Erasmus's Colloquium "The Old Men's Chat" ............................ 142

A Way of Life and a Mode of Discourse:

The Case of Montaigne ................................................................ $\quad 150$

In Vino Veritas ......................................................................................... 165



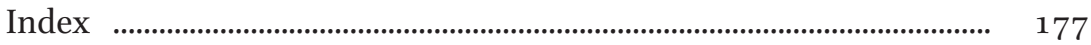


Cynthia Skenazi - 978-90-04-25572-2 Downloaded from Brill.com04/26/2023 02:43:17PM via free access 


\section{ACKNOWLEDGMENTS}

It is a pleasure to express my gratitude to Floyd Gray and François Rigolot for their perceptive comments at various stages of this work. My thanks go also to Brian Copenhaver, Philippe Desan, George Hoffmann, Mary McKinley, Carole Paul, Dora Polachek, François Rouget, Robert Williams, Colette Winn, and Cathy Yandell. The organizers and audiences of the many conferences that gave me the opportunity to present and discuss some elements of the following chapters helped me to reshape many aspects of this book. I should like to thank the staff of the library of the University of California, Santa Barbara-especially Jane Faulkner-for their assistance throughout the course of the project. I owe a special debt to Roxanne Lapidus and to Marianne Noble for editorial assistance. My thanks also go to Marcella Mulder of Brill.

Earlier versions of parts of some chapters have appeared in the following publications: Bibliothèque d'Humanisme et Renaissance LXVIII, 2 (2006), pp. 289-305, and LXX, 3 (2008), pp. 579-93; Vieillir à la Renaissance, ed. Colette Winn and Cathy Yandell (Paris: Champion, 2009), pp. 339-57; "'The Ages of Life': Living and Aging in Conflict?", ed. U. Kriebernegg and R. Maierhofer (Bielefeld: Transcript Verlag, 2013), pp. 147-57. Permission to reuse this material is gratefully acknowledged. 
Cynthia Skenazi - 978-90-04-25572-2 Downloaded from Brill.com04/26/2023 02:43:17PM via free access 


\section{ABBREVIATIONS}

Fam. Petrarch. Letters on Familiar Matters (Rerum Familiarium Libri). 3 vols. Edited and translated by Aldo Bernardo. Albany, New York: State University of New York Press, 1975; Baltimore: Johns Hopkins University Press, 1985.

Lettres Pétrarque. Les Lettres de la vieillesse. 4 vols. Edited by E. Nota, Ugo Dotti, Claude Laurens, and Frank La Brasca. Paris: Les Belles Lettres, 2002-6.

Sen. $\quad$ Petrarch, Letters of Old Age (Rerum Senilium Libri). 2 vols. Edited and translated by A. S. Bernardo, S. Levin, and R. Bernardo. Baltimore: Johns Hopkins University Press, 1992. 
Cynthia Skenazi - 978-90-04-25572-2 Downloaded from Brill.com04/26/2023 02:43:17PM via free access 


\section{INTRODUCTION}

This book investigates stories of growing old from Petrarch's to Montaigne's time. My concerns with this project are twofold. First, I explore a shift in attitudes towards aging. From the late fourteenth to the end of the sixteenth centuries, the elderly subject became a focus of new social, medical, political, and literary attention on both sides of the Alps. A movement of secularization-inspired by the revival of classical literature-tended to dissociate old age from the Christian preparation for death, and downplayed the role of the afterlife, re-orienting the concept of aging around pragmatic matters such health care, intergenerational relationships, and insights one might acquire in later life and pass along. Such changes were accompanied by an increasing number of personal accounts of later life expressed from a variety of perspectives, and in multiple ways. As old age became the subject of intense personal reflection and widespread public debate, new literary forms of elder identity appeared, which drew upon previous texts, combined several sources, subverted them, and departed from them. Stories of growing old became more differentiated and complex, yet these self-portraits were less the faithful records of lived experiences than rhetorical constructions that took their full meaning in a society and culture increasingly interested in questions related to longevity.

My second goal is to provide a historical perspective on a crucial problem of our time. The United Nations foresees an unprecedented global demographic transformation in the near future: by 2050, people aged sixty and beyond will outnumber those under fifteen. Currently, the fastest growing segment of the Western World is those aged eighty-five and beyond. Looking back to the fifteenth and sixteenth centuries, the few demographical statistics indicate that life expectancy at birth averaged around thirty-five years in parts of Italy and France. However, historians have noticed an extension of the life span during this period, partly the result of a decrease in birth mortality rates. ${ }^{1}$ Nevertheless, people did grow old in the Renaissance, and in larger numbers than is often thought,

${ }^{1}$ See Christiane Klapisch and D. Herlihy, Les Toscans et leur famille: une étude du catasto florentin de 1427 (Paris: Ecole des Hautes Etudes et Fondation nationale des Sciences Politiques, 1978); Arlette Higounet-Nadal, Périgueux aux XIV et XVe siècles. Etude de démographie historique (Bordeaux: Fédération historique du Sud-Ouest, 1977), pp. 805-15. See also Georges Minois, Histoire de la vieillesse en Occident de l'Antiquité à la Renaissance (Paris: Fayard, 1987), pp. 287-337. 
although the definition of old age varied from place to place and according to one's point of view, as we shall see. My working assumption is that common denominators across centuries are as revealing as significant differences: my aim is to consider how accounts from a distant period help us to see what might be universal in the ways Western culture deals with an irreversible biological phenomenon. Shifting the focus from a particular time period to a broader context allows a series of concerns to come to the fore. Throughout the centuries, aging people have had similar aspirations and anxieties about human life: coping with changes in their cognitive and physical capacities; keeping the affection of relatives and the esteem of their social group; remaining active in their communities. On the one hand, my findings convinced me that one learns more about how to respond to these challenges by reading Petrarch, Montaigne and their classical sources than contemporary self-help books. On the other hand, my reading of Renaissance stories of later life pointed out that personal experiences are embedded in the systems of knowledge (cultural, social, medical, and so on) of the day.

The texts that are investigated offer forms of resistance to the view of aging as a process of straightforward physical and cognitive decay, and it is this perspective more than anything that allows me to bring together materials that are usually kept separate. The notion of old age is not challenged, but there is a refusal to see it as totally negative and unproblematic, and an attempt to focus on the quality of the elder's lifestyle as well as on the meaning of his later years. I do not offer a narrow definition of the notion of "aging gracefully," since its meaning depends not only on an individual's personal values and priorities, but also on those of the cultural and historical context in which this individual lives. Rather, the various chapters of this study provide an array of perspectives on how to age gracefully. In its broadest application, my work will enhance our own perceptions of aging gracefully by revisiting the formative writing on this issue in Renaissance stories of later life. This book will, I hope, build a bridge between the cultures of Petrarch's and Montaigne's time, and the twenty-first century. It is this anthropological perspective that inspired my project. Moving from the view that growing old is something that "happens" to people, I study it as a process with which individuals have to engage and which requires a variety of skills - self-understanding, observation, adaptation, imagination, and humor-to compensate for losses and perhaps turn them into opportunities. As such, this work will be of interest to historians, literary scholars, students, sociologists, and social gerontologists alike. 
Petrarch and Montaigne, and the centuries that separate them are at the heart of my study. Both authors' works epitomize a turn inward towards a psychological and philosophical investigation of human identity-towards what we now call "the self." Scholars have long seen in this turn the mark of Petrarch's and Montaigne's modernity; yet ever since the publication of Jacob Burckhardt's influential book, The Civilization of the Renaissance in Italy (186o), ${ }^{2}$ critics have focused on creating a static conception of identity from Petrarch onward, without taking into account the "aging factor." Petrarch claimed to have "gray hair considerably before [his] twenty-fifth year;"3 his self-portraits in works as different as his Letters on Familiar Matters, his Letters of Old Age, his Secretum, and his Rime Sparse (or Rerum Vulgarium Fragmenta as he used to call this collection) refer to a writer growing old. Likewise, Montaigne's obsession with time has attracted much comment, but his pervasive references to himself as an old man have not been fully appreciated. At age forty (seven years before the first edition of his Essais in 1580), he considered himself "engagé dans les avenuës de la vieillesse" ("well on the road to old age" (II, 17, p. 641/p. 590)). ${ }^{4}$ He found ways to confront death, but growing old proved a more challenging and pressing task. For both authors, the process of aging was a mode of thought that opened up new ways to relate to oneself, to the other, and the world. Their respective experiences drew their attention to questions of literary self-perception, and contradicted the prevailing view that old age is a distinct stage of life, with common and homogeneous characteristics. The eroding of an "ages of life" culture and the awakening to the instability of individual identity across time carried with it the potential for increased self-understanding, as we shall see.

Petrarch's self-portraits in old age have religious and moral overtones; in the Letters of Old Age especially, they blend Christian and pagan perspectives to present the author as a Christianized Ancient. About

2 Jacob Burckhardt, The Civilization of the Renaissance in Italy, trans. S. C. C. Middlemore, introd. B. Nelson and C. Trinkaus (New York: Harper, 1958). See also Stephen Greenblatt, Renaissance Self-Fashioning. From More to Shakespeare (Chicago: Chicago University Press, 1980).

3 "canos aliquot ante vigesimum quintum annum habui..." Le Familiari, ed. V. Rossi (Florence: Sansoni, 1934), VI, 3, vol. 2, p. 67. All Latin references are taken from this edition. Letters on Familiar Matters (Rerum Familiarium Libri), trans. and ed. Aldo Bernardo (Albany, New York: State University of New York Press, 1975), VI, 3, vol. 1, p. 303. All English translations refer to this edition and are incorporated into the text.

4 Page numbers for Montaigne's Essais refer first to the standard edition, edited by Pierre Villey and Verdun-L. Saulnier (Paris: PUF, 2004), and then to Donald Frame's translation The Complete Works of Montaigne (New York: Knopf, 2003). 
two hundred years later, Montaigne's Essais offered another powerful self-representation. In contrast to the relative cohesion of Petrarch's various self-portraits in old age, Montaigne offered a polyphonic and mobile image of his aging self, marked by discontinuities, and contradictions. Like Petrarch, Montaigne pointed to early signs of old age. From his thirties on, he was certain that "since that age, [his] mind and [his] body ha[d] rather shrunk than grown, and gone backward rather than forward" (I, 57, p. 327/p. 289). Such comments need a closer look, as we shall see.

My analyses are indebted to previous scholarship on Petrarch, Montaigne, and the Renaissance. Stephen Greenblatt's study on Renaissance Self-Fashioning has been inspirational insofar as it focuses on an individual's power to shape his own image, and investigates how representations are embedded in different structures of power specific to a certain community. Greenblatt, however, does not examine the importance of elders' self-portraits in the formation of early modern subjectivity. Works on Montaigne by Hugo Friedrich, Jean Starobinski, and Craig Brush have also been useful. Victoria Kirkham and Armando Maggi's edited collection of essays on Petrarch have been likewise very helpful..$^{5}$ In contrast to these critics, I have attempted to provide a historically specific sense of personal stories of old age by reading them in the intellectual and social context out of which they arose. Petrarch's and Montaigne's self-portraits in their later life, I contend, responded to contemporary arguments on age, and either endorsed, questioned, repudiated, or ignored prevailing assumptions on this issue. My views on aging have benefited from works by Helen Small, Sulamit Shahar, Nina Taunton, Pat Thane, and Kathleen Woodward, among others. ${ }^{6}$ In addition, in their recent editions of essays, Erin Campbell, Albrecht Classen, Colette Winn and Cathy Yandell have

5 Greenblatt, Renaissance Self-Fashioning; Hugo Friedrich, Montaigne, trans. D. Eng, (Berkeley: University of California Press, 1991); Jean Starobinski, Montaigne en mouvement (Paris: Gallimard, 1983); Craig B. Brush, "What Montaigne has to say about old age," in $O$ un amy! Essays on Montaigne in Honor of Donald M. Frame, ed. Raymond C. La Charité (Lexington, Ky: French Forum, 1977), pp. 89-118; Victoria Kirkham and Armando Maggi, eds., Petrarch: A Critical Guide to the Complete Works (Chicago: University of Chicago Press, 2009).

6 Helen Small, The Long Life (Oxford: Oxford University Press, 2007); Sulamit Shahar, Growing Old in the Middle Ages. "Winter Clothes Us in Shadow and Pain," trans. Yael Lotan (London, Routledge, 1997); Nina Taunton, Fictions of Old Age in Early Modern Literature and Culture (New York: Routledge, 2007); Pat Thane, The Long History of Old Age (London: Thames and Hudson, 2005); Kathleen Woodward, At Last, the Real Distinguished Thing: The Late Poems of Eliot, Pound, Stevens, and Williams (Columbus, Ohio: Ohio State University Press, 1980). 
added a great deal of information on old age in the Renaissance. ${ }^{7}$ Georges Minois's History of Old Age from Antiquity to the Renaissance has also fed my reflections, ${ }^{8}$ although my study challenges his contention that the Renaissance epitomized a cult of youth and a general criticism-even hatred - of the elderly. At every given historical moment, indeed, concurrent perspectives on age circulate within a specific social group. By taking into account this diversity, a more richly textured history emerges that makes clearer differences among individuals, social and political groups, as well as times and places.

In contrast to these previous works on old age in the Renaissance, the theoretical approach for this project takes as a point of departure Michel Foucault's research on the "care of the self" as weaving together individuality and collectivity. Foucault never spoke of old age, yet his research has provided apt tools for sociological discussions on the construction of gerontology as a discipline, and on postmodern views on aging identity. ${ }^{9}$ In "The Subject and Power," he offered a retrospective account of his intellectual undertakings: "My objective [...] has been to create a history of the different modes by which, in our culture, human beings are made subjects." ${ }^{10}$ His focus on the constitution of the self as a subject of desire in his History of Sexuality (especially in the second volume, The Use of Pleasure) is only one of the historical forms in which the subject "was problematized, becoming an object of concern, an element for reflection, and a material for stylization." 11 Drawing on a number of strands, including

7 Erin Campbell, ed., Growing Old in Early Modern Europe. Cultural Representations (Burlington, Vt: Ashgate, 2006); Albrecht Classen, ed., Old Age in the Middle Ages and the Renaissance: Interdisciplinary Approaches to a Neglected Topic (New York: De Gruyter, 2007); C. Winn and Y. Yandell, eds., Vieillir à la Renaissance (Paris: Champion, 2009).

8 Georges Minois, Histoire de la vieillesse en Occident de l'Antiquité à la Renaissance, pp. $287-337$.

9 See Stephen Katz, Disciplining Old Age. The Formation of Gerontological Knowledge (Charlotte: University of Virginia Press, 1996), especially pp. 6-24; Jason Powell and Azrini Wahidin, ed., Foucault and Aging (Hauppauge, NY: Nova Science Publishers, 2006).

10 Michel Foucault, "The Subject and Power," in Michel Foucault Beyond Structuralism and Hermeneutics, ed. H. L Dreyfus and P. Rabinow (Chicago: Chicago University Press, 1983), pp. 208-9. See also "The Ethic of Care for the Self as a Practice of Freedom. An Interview with Michel Foucault on January 20, 1984," in The Final Foucault, ed. James Bernauer and David Rasmussen (Cambridge, Mass.: MIT Press, 1988), p. 10: "What I wanted to know was how the subject constituted himself, in such and such a determined form, as a mad subject or as a normal subject, through a certain number of practices which were games of truth, applications of power, etc."

11 Michel Foucault, The History of Sexuality vol. 2, The Use of Pleasure, trans. R. Hurley (New York: Pantheon Books, 1986), pp. 23-24. 
Pierre Hadot's research on spiritual exercises in the culture of Antiquity, ${ }^{12}$ Foucault's later works studied "an aesthetic of existence" where the individual seeks to shape his life through conscious self-fashioning. In his lectures on L'Herméneutique du sujet at the Collège de France, he highlighted a new consciousness of the "relation of oneself to oneself" ("rapports de soi à soi") dominated by the idea of "care for oneself" ("souci de soi") in texts mostly from the Hellenistic period. This involved not only a general attitude, but also working on the self through a number of practices ("technologies de soi"). ${ }^{13}$ Foucault envisioned the care of the self in a triple perspective, as 1) a general way of considering things, a way of being; 2) a form of attention to oneself; 3) a number of practices that an individual performs on himself which shape his behavior and mode of being. The common objective of these "pratiques de soi" is a conversion to oneself, which involves a shift of perspective, and "a trajectory thanks to which, escaping all dependency and enslavement, we return to ourselves, as to a harbor sheltered from storms."14 L'Herméneutique du sujet discusses practices ranging from health regimens to the Delphic imperative of knowing oneself in Platonic dialogues, and to Stoic and Epicurean conceptions of human life.

Foucault argued that the turn to the self-and to self-knowledge-has meant different things under different regimes of self-formation. His studies on the constitution of different forms of the subject in specific time periods show how some fields of knowledge have constrained human freedom and attempt to provide the intellectual resources for overcoming current constraints by replacing them in a historical perspective. His work has provided analytical paradigms of wider applicability, and my inquiry is yet another confirmation of the vitality of his legacy. In fact, I might apply to my use of his historical framework what Foucault himself rather teasingly said of Nietzsche:

The only valid tribute to thought such as Nietzsche's is precisely to use it, to deform it, to make it groan and protest. And if commentators then say

12 Pierre Hadot, Exercices spirituels et philosophie antique (Paris: Etudes augustiniennes, 1981). See also P. Hadot, Philosophy as a Way of Life, ed. A. I. Davidson, trans. M. Chase (Chicago: Chicago University Press, 1995).

13 Michel Foucault, L'Herméneutique du sujet. Cours au Collège de France 1981-1982, ed. F. Ewald, A. Fontana, F. Gros (Paris: Gallimard, 2001), pp. 12-13.

${ }_{14}$ Michel Foucault, The History of Sexuality, vol. 3, The Care of the Self, trans. R. Hurley (New York: Vintage Book, 1986), p. 57. 
that I am being faithful or unfaithful to Nietzsche that is of absolutely no interest. ${ }^{15}$

My study elaborates on Foucault's project of "a history of the different ways in our culture that humans develop knowledge about themselves,"16 in a new direction and another time period. Each chapter examines stories of growing old along Foucault's major axes of research-medicine, power, love, and most importantly, the body-in a different sphere: private life, the public realm of political affairs, the social world of the court and salons. ${ }^{17}$

Chapter 1, "A Sound Mind in a Healthy Body," examines the creation of a market for health regimens among wealthy seniors. The old man became an object of medical observation; his daily health care was a matter of private preoccupation, as shown in texts by Petrarch, Ficino, Zerbi, Erasmus, Cornaro, and Montaigne. Chapter 2 discusses the "Circulation of Power and Knowledge" among generations, given that a large number of male elders held high positions in the public sphere. Amidst political turmoil, the reactions of Petrarch, Castiglione, and Montaigne to Cicero's defense of gerontocracy in De Senectute offered ways to restore social peace and harmony through dialogue between youth and old age. Chapter 3, "Love in Old Age," is about aged writers who acknowledged themselves as subject to desire and sought new ways to articulate the stereotypes of both the chaste and the lustful old man, as well as the traditional opposition of old versus young. Petrarch addressed these questions within a Christian framework; with the graying of the courts and salons of the sixteenth century, however, the posture of the aged lover led Ronsard, Montaigne, and Pasquier to raise issues concerning social behavior. Finally, chapter 4, "Then and Now," addresses the connection between these newly conceptualized representations of old age and the notion of aging gracefully in the present time; it also discusses self-portraits of later life- especially Montaigne's-in terms of discursive tactics. Although the assumptions underlying Renaissance self-representations of later life differ from those of the twenty-first century, their investigation into aging as

15 M. Foucault, "Prison Talk," in Power/Knowledge. Selected Interviews and Other Writings, 1972-1977, ed. C. Gordon (Brighton: Harvester, 1981), pp. 53-54.

16 L. H. Martin, H. Gutman, and P. H. Hutton, eds., Technologies of the Self: A Seminar with Michel Foucault (Amherst, MA: University of Massachussetts Press, 1988), pp. 17-18.

17 See especially Michel Foucault, Surveiller et punir. Naissance de la prison (Paris: Gallimard, 1975); Histoire de la folie à l'âge classique (Paris: Gallimard, 1961); Histoire de la sexualité, vol. 1 (Paris: Gallimard, 1976); Naissance de la clinique. Une archéologie du regard médical (Paris: PUF, 1963). 
a process of self-understanding and an attempt to adapt to human finitude still speaks to us.

This work is not the story of a progressive refinement of selfrepresentations from Petrarch's to Montaigne's time; indeed, there is no single history of old age. All these authors, nevertheless, referred to the same biblical, medical, and literary sources, as well as to a common set of literary conventions, and stereotypes of age. The four chapters are relatively independent studies and do not constitute a progressive story, although they move from questions concerning an individual's cognitive and physical capacities to issues regarding his relationships with others. Moreover, their lines of inquiry have in common issues of adaptation and self-knowledge.

By reconfiguring our conception of aging through Foucault's notion of "care of the self" as a practice of both the individual and the collective, my work capitalizes on Foucault's invitation to further exchange on this matter, and contributes to ongoing conversations between the humanities, the sciences, and the social sciences on aging.

The remainder of this introduction discusses the notion of old age and defines my field of inquiry.

\section{Old Age}

Any attempt to address the issue of aging must acknowledge that this discourse involves multiple perspectives-biological, chronological, social, psychological, functional, cultural, and so on. In addition, each individual has a subjective estimate of his own condition, which may not correspond to the way he looks in the eyes of others. No unified view can take into account all these levels. There is no overarching definition of old age. Moreover, if death marks the end of old age, how do we identify the beginning of this phase? In the schemes for the division of life into stages elaborated from classical Antiquity through the sixteenth century (the number of these stages varied from three to seven, and could even go up to twelve), ${ }^{18}$ several ages were suggested as the onset of old age: thirty-five, forty-five, fifty, sixty, seventy. These schemes referred to specific contexts (religious, medical, scientific, literary, among others) and to

18 See Samuel Chew, The Pilgrimage of Life (New Haven: Yale University Press, 1962), pp. 148-73; Elizabeth Sears, The Ages of Man. Medieval Interpretations of the Life Cycle (Princeton: Princeton University Press, 1986). 
different social groups; as such, they related to different conceptions of human nature and of time.

The earliest representations of the course of life as a rising and declining stairway appeared between the end of the fifteenth century and the middle of the next century. The image was so evocative that it quickly spread in German, French, and English prints; Paris became an important center for its production in the sixteenth century. ${ }^{19}$ In a late fifteenthcentury German print, for instance, we see a staircase with a cradle at ground level; ascending the stairs appear in succession a child, an adolescent, and a young man. On the landing there is a middle-aged man. On the right the man goes down gradually as he grows older, and reaches a deathbed, then a tomb. One of the paradoxes of these representations is their acknowledgment that human beings are aging from the moment of their birth, but at a certain point in life they are identified as "old." Chronological age explains nothing; it is only an arbitrary index. Nor is aging a homogeneous and even process; each of us ages in a particular way; moreover, we all grow old "by pieces" insofar as the various parts of our body and mind age at different rates.

The aging family of words can be understood as a concept only in the sense in which Ludwig Wittgenstein used the term "concept," that is, as a rope composed of numerous interwoven fibres that are neither identical nor unrelated to each other: "the strength of the thread does not reside in the fact that some one fibre runs through its whole length, but in the overlapping of many fibres." ${ }^{20}$ For Wittgenstein, the meaning of a concept lies in its uses. ${ }^{21}$ Since "old age" embraces a great diversity of capacity and experience, writers such as Petrarch and Montaigne selected certain aspects from its wide range of meanings to instigate precise actions, to discuss some practices, to judge some behaviors, provoke feelings, and question various beliefs. Old age lends itself well to debates because it often involves evaluation, celebration or denigration, but rarely indifference. In every period, it has been praised and cursed, honored and resented. In the Renaissance, arguments in praise of and against it were gathered from the Greeks and Romans, the Bible, the Church fathers, as well as medieval writers. The extreme texts bore the imprint of remarkably

19 David Troyansky, Old Age in the Old Regime. Image and Experience in 18th-Century France (Cornell: Cornell University Press, 1989), p. 12.

20 Ludwig Wittengstein, Philosophical Investigations (Oxford: Oxford University Press, 1968), p. 32.

21 Ibid., p. 20. 
stable — negative or positive — stereotypes of age. Aristotle's Rhetoric and Nicomachean Ethics disseminated negative stereotypes by describing the old man as selfish, mean, bitter, cowardly unreliable, suspicious, and socially dysfunctional. For Aristotle, the old man idealizes his past and blames the present; his alleged experience is the sum of the mistakes he made in the course of his long life. ${ }^{22}$ Plato's Republic and Cicero's Cato Maior De Senectute, on the other hand, celebrated old age, stressing the elder's wisdom, serenity, and perceptive judgment. ${ }^{23}$ This fundamental dialectic, which has long roots in Egyptian, Jewish, and Babylonian traditions, ${ }^{24}$ shows the relational nature of age stereotypes: the qualities attributed to old age are in fact the shortcomings attributed to youth, and vice-versa. The figures on whom this study focuses questioned the nature of these binary views, as we shall see.

So far, I have left aside an obvious question: how visible were the elders in Petrarch's and Montaigne's societies? How old were they? According to Petrarch, longevity had become a banal aspect of everyday life:

Plato lived to be eighty-one; and it is said to have been considered such a phenomenon that, because he had completed the most perfect age, it was acknowledged that the Magi offered sacrifices to him as though he were more than a man, whereas today in our cities we see this kind of longevity all around; octogenarians, and nonagenarians are common...(Sen. XVII, 2, p. 651$)^{25}$

22 Aristotle, On Rhetoric. A Theory of Civic Discourse, ed. and trans. G. Kennedy (Oxford: Oxford University Press, 2007), II, 13, 1389b-90a; Nicomachean Ethics, ed. and trans. E. D. Ross (Oxford: Oxford University Press, 1980), IV, 3, 1121; VIII, 7.

23 Plato, The Republic, ed. and trans. R. Allen (New Haven: Yale University Press, 2006) I, 1328a-1330c, p. 76; Cicero, De Senectute, De Amicitia, De Divinatione, ed. and trans. W. A. Falconer (London: Heinemann, 1923). On Cicero's De Senectute, see chapter 2.

24 See Jan Baars, "Philosophy of Aging, Time, and Finitude," in A Guide to Humanistic Studies in Aging. What Does It Mean To Grow Old?, ed. Thomas R. Cole, R. E. Ray, and R. Kastenbaum, (Baltimore: Johns Hopkins University Press, 2010), pp. 107-8; and Stephen Sapp, "Aging in World Religions. An Overview," in Cole, Ray, and Kastenbaum, A Guide to Humanistic Studies in Aging, pp. 129-33.

25 Petrarch, Letters of Old Age (Rerum Senilium Libri), trans. and ed. A. S. Bernardo, S. Levin, and R. Bernardo (Baltimore: Johns Hopkins University Press, 1992), vol. 2, book XVIII, letter 2, p. 651. All further references are taken from this edition (abridged mention: Sen.) and incorporated into the text. The first-Roman-number refers to the book number, the second one to the letter number. When needed, I have added a reference to the Latin text taken from Les Lettres de la vieillesse, 4 vols., ed. E. Nota et al. (Paris: Les Belles Lettres, 2002-6), (abridged mention: Lettres). Nota's edition is far superior to the previous ones. Vol. 5 appeared too late for me to consult it. For the Latin text of the last books of the Seniles, I have therefore consulted F. Petrarca, Le "Senili" secondo l'edizione Basilea 1581, ed. Marziano Guglielminetti, M. Martelli, and P. Pellizzari (Torino: L’Artistica Editrice, 2004). 
Petrarch knew that Cato, Varro, and other Ancients had become centenarians, but found the frequency of contemporary cases of old age striking. His own paternal great-grandfather passed away in "the one hundred and fourth year of life," he wrote to Giovanni Colonna (Fam. vol. 1, VI, 3, p. 302$).{ }^{26}$ In addition, he mentioned a famous hermit, Romuald of Ravenna, who "recently lived a hundred and twenty years" (Sen. XVII, 2, p. 651). About two centuries after Petrarch's observations, Girolamo Cardano recalled his conversations with a tailor from Padua who claimed to be a centenarian, and with a Milanese baker and a man from Pavia who both said they were ninety-six years old. Cardano, who boasted about his ability to judge age accurately, thought that the man from Pavia was only ninety years old because he was not as thin as the other two, and his eyelids were not that deeply sunken. All three men were healthy, but the native of Padua suffered from constipation and memory losses. Cardano concluded that in contemporary Italy one could live up to one hundred years, but that only octogenarians had their mental and physical faculties relatively intact. ${ }^{27}$ Some information Petrarch and Cardano got hold of was clearly flawed. Moreover, people who were vague about their chronological age gave themselves an arbitrary birth date to show that they were old. In everyday life, old age was primarily a matter of physiological marks and capacities, hence a man could be identified as "old" at variable ages.

On the other hand, Montaigne thought that dying of old age was "a rare death, unique and out of the normal order." At age forty-seven, he considered being at an age "few people reach" and thought he had "passed the customary limits which are the true measure of our life" (I, 57, p. 326/p. 288). He was closer to the truth than were Petrarch or Cardano. Yet as soon as one starts thinking in terms of longevity, a host of famous French and Italian writers who lived beyond age sixty comes to mind: Petrarch (1304-1374), Leone Battista Alberti (1404-1472), Girolamo Cardano (1501-1576), Blaise de Monluc (ca. 1502-1577), Etienne Pasquier (1529-1615), Simon Goulart (1548-1628), Philippe Duplessis-Mornay (15491623), Agrippa d'Aubigné (1552-1630), and more. Philip Sohm has made a similar observation in the visual arts: from 1500 to 1700 , two-thirds of

\footnotetext{
26 "quarto ac centesimo etatis anno," Familiari, vol. 2, p. 66. On Petrarch's greatgrandfather, see chapter 1 , the section on Petrarch.

27 Girolamo Cardano, Opera 6: 57, quoted by Nancy Siraisi, The Clock and the Mirror. Girolamo Cardano and Renaissance medicine (Princeton: University Press, 1997), p. 40.
} 
the 975 Italian painters with a known date of birth were sexagenarians or beyond by the time of their death. ${ }^{28}$

When it came to life expectancy, the gap between the rich and the poor was obvious. Interestingly, Francis Bacon (1561-1626), who was deeply concerned with issues of longevity, observed that seventeenth-century members of the Church of England (high-ranked ecclesiastics, monks, and nuns from prosperous abbeys and convents) and people from the professions with a comfortable income and a high level of education had the best chance of living long lives. ${ }^{29}$

\section{Scope of This Inquiry}

Clearly, old age's multiple forms of expression and representation are a major part of a cultural and intellectual investigation of the Renaissance. Yet an exhaustive analysis of this question is unrealistic since it is impossible to reconstruct the context of a distant period in its entirety. This problem is particularly acute in the present case since the notion of old age "functions" without a sharp distinction between literature and other disciplines. My inquiry crosses the boundaries between medicine, ethics, and the construction of literary characters; it concerns private and public matters; it involves examining social modes of behavior and reflections on the cultural codes that partly shape these behaviors. Analyses of old age also must take into account gender, class, historical and personal circumstances.

Given the scope of these issues, I should emphasize what this book does not discuss. Hence my study is as important for what it leaves out as for what it includes, and, ultimately, for the interest it may provoke in others to broaden this inquiry. I have not addressed the female experience of aging, which differed from that of the male experience and had its own set of issues. From Antiquity to the Renaissance, men wrote health regimens and medical treatises for a male audience, although most advice applied to women as well. Moreover, questions related to age in political affairs usually referred to male elders; other problems such as intergenerational

28 Philip Sohm, The Artist Grows Old. The Aging of Art and Artists in Italy, 1500-180o (New Haven: Yale University Press, 2007), p. 15.

29 Francis Bacon. The Instauratio Magna, vol. 3, Historia naturalis et experimentalis. Historia ventorum. Historia vitae et mortis, ed. G. Rees (Oxford: Clarendon Press, 2007), chapter 20. 
conflicts and social behaviors in old age are also gender-specific. I have not included problems related to the poor and the creation of asylums for the elderly. In turning to literature I have not included plays. Although they often portray old men, they do not provide much insight on personal stories of later life. I have not addressed questions related to "fountains of youth," occult means of rejuvenation, and attempts to live forever, which lie outside my investigation. Finally, I do not include representations of death since my study focuses on the dissociation of old age from such views.

Instead, I have examined poems, letters, and prose texts by major Italian and French writers who grew old in the upper social classes and the cultural elite of their time. These are stories that go in different directions, depending on the point of view from which they are told, the context, the date, the implied audience, and so on. My study takes up samples of such representations. Petrarch and Montaigne are present throughout the four chapters because their self-portraits provide us with the most complex and thorough perspectives on the aging self. Some authors appear only episodically, depending on the nature and impact of their views. The medical treatises of Zerbi and Ficino are part of the discussion on the care of the aging self, as is Cornaro's powerful text on health at old age (chapter 1). Erasmus's ironic paradoxes on old age in Praise of Folly and his religious perspectives on health in later life appear in the same chapter. Castiglione's Libro del Cortegiano appears in chapter 2 since it raises important concerns on the social and political implications of old age. Ronsard and Pasquier are part of the chapter on love in old age (chapter 3).

There is a network of connections among these writers. Montaigne knew Petrarch's works, including his correspondence; he had read Ficino, Erasmus, Castiglione, Ronsard, and perhaps Cornaro. Moreover, he was a friend of Pasquier, who admired his Essais. The love verses of Pasquier and Ronsard bore the imprint of Petrarch's Rerum Vulgarium Fragmenta.

We will now turn to how these writers capitalized on a common literary and scientific tradition, as well as on the various constraints that weighed upon them as they fashioned themselves in the winter of life. 
Cynthia Skenazi - 978-90-04-25572-2 Downloaded from Brill.com04/26/2023 02:43:17PM via free access 


\section{A SOUND MIND IN A HEALTHY BODY}

In The Use of Pleasure and in his lectures at the Collège de France on the Hermeneutics of the Subject, Foucault studied different practices associated with the care of the self. For the intellectual male elite of Greek and Roman Antiquity, to know oneself was founded upon the pragmatic commitment to take care of oneself. ${ }^{1}$ The Platonic dialogues mark a pivotal moment since the care of the self became inseparable from the Delphic imperative of knowing oneself: in order to take care of oneself properly, Socrates tells his interlocutor, one must know oneself, that is one must know how to take care of oneself. Therefore, Foucault argues that the "self" was experienced through a plurality of experiences, activities, and practices which infused one's relations with the world, with others, and with oneself. These practices included, among others, techniques of thought and concentration, physical exercises, and attention to one's diet. Regardless of their varieties, all of them required a form of self-control and attention to oneself. Texts on the regulation of bodily activities did not just offer precise rules for good health but developed an overall art of existence. Ancient dietetics' primary goal, for instance, was not the prolongation of life but its quality: the search for pleasurable health within natural bounds and in harmony with the cosmos. "The care for self was in the Greco-Roman world the manner in which individual-and civic liberty, up to a certain point-considered itself ethical," Foucault observes. ${ }^{2}$ By ethos he means "the deportment and the way to behave," the "subject's mode of being and a certain manner of acting visible to others." ${ }^{3}$

Foucault never took into account the "aging factor" when it comes to the care of one's health. My goal is to see how Petrarch's and Montaigne's contemporaries appropriated and adapted views on the care of the self from the classical and Hellenistic periods in this respect.

1 M. Foucault, The Use of Pleasure, p. 101.

2 M. Foucault, "The Ethic of Care for the Self as a Practice of Freedom", p. 4.

3 Ibid., p. 6. 
Indeed, is aging a natural process, as Galen contended, or is it a disease, as Aristotle argued? ${ }^{4}$ Both views persisted in Renaissance texts, as we will see. Today the word "health" usually suggests "absence of illness," yet this complex and subjective notion does not exclude the presence of latent risk factors or possible medical interventions. The preamble to the 1948 Constitution of the World Health Organization defines health in somewhat vague terms, as "a state of complete physical, mental, and social well-being and not merely the absence of disease or infirmity." ${ }^{5} \mathrm{But}$ for centuries, health was a matter of balance or "proportion." HippocraticGalenic medicine explained all processes of life as the interaction of four basic qualities (hot, cold, dry, and moist). Human life involved a continuous combustion of the body's innate heat and radical moisture, the latter fueling the former, analogous to the flame fed by the burning wick and oil in a lamp. Health depended on a balanced proportion of innate heat (calor naturalis) and radical moisture (humidum radicale) as well as an appropriate mixture of the humors (body fluids) — phlegm, blood, choler or yellow bile, and melancholy or black bile-each of which was linked to a specific temperament or complexio. Many factors, including age and health, affected the temperaments, which constituted "an extremely intricate and far-reaching system of explanation that underpinned much of physiology, pathology, and therapy." ${ }^{6}$ Senescence was a progressive cooling and drying of the body, with a rise in the melancholic humor, and ultimately in the phlegmatic one. Natural death was the result of these unavoidable physical developments, when all that was left of the body's heat and moisture was no longer capable of being transformed into fuel for maintaining a person alive. ${ }^{7}$

In what follows we will investigate stories of later life ranging from Ficino's and Zerbi's health regimens to personal accounts by Petrarch, Erasmus, Cornaro, and Montaigne. These stories appear in private letters, poems, literary essays, and paradoxical monologues such as Erasmus's Praise of Folly. These writers all shared a renewed interest in the care of

4 Galen, On Hygiene. De Sanitate tuenda, ed. and trans. R. M. Green. (Springfield, Il.: Thomas, 1951). I, 2. All further references come from this edition and are incorporated into the text. Aristotle, Generation of Animals, ed. and trans. G. P. Goold. The Loeb Classical Library (Cambridge, Mass.: Harvard University Press, 1979), V, 5, 784b, 32-34, pp. 530-31.

5 See http://www.who.int/about/definition/en/print.html. Accessed March 14, 2013. The definition is dated April 7, 1948. On a historical perspective on health, see Klaus Bergdolt, Wellbeing. A Cultural History of Healthy Living, Trans. J. Dewhurst (London: Polity, 2008).

${ }^{6}$ Siraisi, The Clock and the Mirror, p. 64.

7 Ibid., p. 75 . 
the aging self and in pragmatic ways of minimizing the effects of time on human physical and cognitive capacities. Although their interest was linked to the development of certain forms of experimental medicine, Hippocrates's texts and Galen's observations on the process of aging were the bases of Western medicine for more than 1,500 years, and thus deserve our scrutiny. Galen's fifth book of De Sanitate tuenda, in particular, influenced all subsequent discourses on the preservation of health in old age, and on the prolongation of life.

\section{Galen}

Galen reinforced the humoral theory of the Hippocratic treatise De Natura humana. According to this view, the four humors in the human body correspond to, and sympathetically interact with, the four elements that constitute the sublunary world (air, fire, earth, water) and the elementary qualities of which both sets are made. In this cosmic perspective, blood is connected with air and the qualities warm and moist; yellow bile is connected with fire as warm and dry; black bile relates to earth as cold and dry; phlegm corresponds to water as cold and moist. The metaphor of the seasons to characterize the ages of life embodies the dynamic unity between the human microcosm and the world. By relocating human existence within the universal laws of the world, this analogy conveyed an image of life as a perpetual metamorphosis. Following this scheme, the adolescens is impulsive for he is hot and moist like spring; the juventus who has lost part of his former energy is like the summer, hot and dry. Fall is associated with senectus (old age) because both are cold, damp, and inclined to melancholy. As the years go by, the bile increases in the elder's body and the volume of blood decreases. Finally, the decrepit man (senium) is cold and dry like winter, because of a surplus of phlegm; he has exhausted almost all the warmth and hydration required for staying alive.

These medical views on old age were widely accepted by Petrarch's and Montaigne's contemporaries, but opinions varied on the chronological onset of old age. Even Hippocrates and Galen have markedly different views on this question. Of Hippocrates's Seven Ages of Man, the sixth (age forty-five to fifty-six) is called presbutes ("seniority"), and the seventh (from age fifty-six on) is termed geron ("old age"). Galen's fourfold division of life, in which old age (geron) begins at around sixty, prevailed as part of the fourfold humoral scheme, although some fluctuations persisted even beyond the Renaissance. In addition, Galen's treatise On Hygiene 
(De Sanitate tuenda) distinguishes three phases within old age according to the degree of moisture and heat of the human body; each phase refers to different capacities and experiences. The first stage - "green old age"which is a time of fitness and activity, with perhaps some failing powers, does not prevent the elder from pursuing his activities and fulfilling his civic duties. The second one- "old age"-signals a significant decrease of moisture and heat, hence another lifestyle, which Galen describes with two lines of Homer's Odyssey:

When he [the old man] has bathed and eaten, let him sleep

Softly: this is the privilege of age. (V, 3, p. 195)

Finally, during "decrepitude" - the ultimate stage — the body's excessive coldness and dryness leads to natural death. Galen does not specify the chronological limits of each of these three periods since he sees the process of aging in qualitative terms of dryness and coldness. He observes that as the body ages, digestion (a matter of combustion) becomes difficult; other physiological symptoms appear, such as anorexia, emaciation, limited movement and impaired perceptions. As the skin becomes drier and colder it wrinkles; the teeth fall out, the corneas degenerate, and the pulse beats more slowly. Not all the body's parts age at the same rate, however, and Galen does not exclude some individual variations in the general process he outlines. He contends that every human being falls into one of the following medical categories: health, illness, and an intermediary state that includes people in weakened physical condition, such as convalescents and the elderly. Medicine has therefore a dual goal: to fight illness, and to preserve human intellectual and physical capacities. My discussion of health issues in old age will focus on the second task. I should add that Galen's advice on this issue only applies to the first two phases of old age, not to decrepitude.

Galen never believed in eternal youth, but he was concerned about preventing the process of aging from accelerating. His treatise De Sanitate tuenda (On Hygiene) reports the case of two old men, Antiochus and Telephus, whose daily practices and habits were most conducive to the prolongation of life and the conservation of health (V, 4, pp. 201-3). When the physician Antiochus was in his eighties he used to walk every day to attend civic meetings at the forum, or even further to visit the sick. During the winter he kept one room of his house warm; and in the summer he kept it cool. "Here he spent his mornings and was massaged winter and summer, after his toilet" (V, 4, p. 202). Antiochus ate small amounts of food three times a day: at about the fourth hour, "bread with 
Attic honey, generally toasted, but more rarely raw;" at lunch he took first laxative fruits (plums, or figs) and then ate chiefly fish. At dinner he ate "barley with honey-wine", which was soft and "not prone to ferment" or "a game-bird with a simple sauce." Every day Antiochus spent some time in social conversations and often read by himself; he was then massaged in the public bath and performed physical exercises appropriate to his age. "So, caring for himself in this way," Galen concluded, "Antiochus continued until the last day, unimpaired in all his senses and with all his members intact" (V, 4, p. 202). Telephus, the grammarian, grew even older and nearly became a centenarian. He bathed regularly according to the seasons (twice a month in winter, once a week in summer, three times a month in spring and fall). On the days he did not bathe he was anointed with a brief massage. His eating habits were even more austere than those of Antiochus: "barley boiled in water mixed with the best raw honey" at the third hour; vegetables, fish or game at the seventh hour. In the evening he ate only "bread moistened in diluted wine" (V, 4, p. 203).

Nineteen centuries later these practices still make perfect sense. One area of research that today's scientists are excited about is the potential progress in understanding how lifestyle choices (diet, exercise, stress management are among the top factors mentioned) influence the pace of the aging process. ${ }^{8}$ Likewise, Antiochus and Telephus had a lifestyle adapted to their respective physiological conditions, they had a regular schedule of activities, and moderation was at the center of their daily habits. Antiochus had intellectual and social activities that stimulated his mind. Telephus, who was older, took some rest during the day but was still physically active. Both men were sexually continent to preserve their limited strength. The emphasis on their dietary habits is striking since digestion (a matter of combustion of food in Hippocratic-Galenic medicine) was at the center of the conservation of health, and old stomachs need special attention, as we shall see. Any present-day dietitian would applaud the regimen of these old men: Telephus and Antiochus had reduced their food intake; their carefully planned meals were low in fat and easy to digest. They drank a moderate amount of wine every day, which brought warmth to their bodies. For Galen as for today's scientists, the goal is to

8 Alison Kadlec and Ana Maria Arumi, The Science of Aging Gracefully. Scientists and the Public Talk About Aging Research. American Federation for Aging Research and The Alliance for Aging Research (no publication place: Public Agenda, 2005), p. 13. See also chapter 4 , section 1 of this work. 
extend the quality of the elders' lives: the issue is not just to live longer, but rather to keep people healthier and productive in their later years.

Although Antiochus's and Telephus's daily habits were remarkably similar to the recommendations of today's gerontologists, the medical and physiological assumptions underlying their lifestyle differ fundamentally from those of the modern world. In Galen's perspective, a doctor's main concern is old age's dryness with coldness: the man who "learns the moistening and warming materials of the curative agents, would be a good gerontologist," he observes in De Sanitate tuenda (V, 10, p. 219). On Hygiene offers the reader a combination of bookish knowledge and experience. Galen makes use of eclectic written sources; in addition, proven recipes (experimenta) and advice (consilia) to individual patients coexist with historical and illustrative anecdotes (or exempla, such as the cases of Telephus and Antiochus) and personal observations. General principles do not preclude attention to individual cases, quite the opposite. The aim of medical dietetics is a physiological equilibrium, but this equilibrium can only be found empirically because disparate "forces" are at work in each person. Moreover, individuals often have different reactions to the same regimen. Claiming to have "kept patients completely free from illness for many years," Galen notes:

But I should not have accomplished any of this, if I had not understood the physical differences of their bodies, and the hygienic regime suited to each (V, 1, p. 188).

The collaboration between patient and doctor is crucial since the former's experience complements the latter's scientific knowledge of the human body. In fact, an older patient's habits should take precedence over the physician's general medical advice, for as Hippocrates already noted in his Aphorisms, "The things to which one has been used for a long time are usually less harmful even if they are not as good as the things to which one is not used." 9 The implication is that one should adopt a proper lifestyle as early as possible.

Doctors often did not have a good reputation and were widely mistrusted; therefore, Galen's De Sanitate tuenda was a program of self-help rather than the aesthetic stylization of life that Foucault sees in ancient health regimens. Like any author of such a work, Galen intended his

9 Hippocrates, Aphorisms, ed. E. Littré (Amsterdam: Hakkert, 1962), vol. 4, p. 485, aphorism 50. My translation. 
observations to be tested out and even to constitute the framework of daily regimens. In the first chapter of De Sanitate tuenda's book V, he reports following his own precepts from age twenty-eight on, and adds: "It is possible for anyone to guard his own health, who has a free life $[. .$. if one is willing to apply his mind to it" (V, 1, pp. 188-9). In another work, he notes that "those of my friends whom I convinced to exercise, and to lead a regular life are all perfectly healthy, some for over twenty-five years, others for a shorter yet relatively long period." ${ }^{10}$ In addition, De Sanitate tuenda points out the moral implications of the care of the self: how shameful that a man with a perfect constitution should ruin his health in banquets and then need someone else to put the food into his mouth $(\mathrm{V}$, 1, p. 189).

Galen's lasting reputation was partly due to the number of his texts that survived and to the similarities of his views to those of Aristotle. From the tenth century on, Latin and Arab interpreters (including Avicenna) elaborated on his observations; some of them incorporated his theories into astrology and occult systems of thought. Social, cultural, geographic, and economic factors influenced their considerations, yet the content of medieval and Renaissance health regimens remained largely rooted in Hippocratic-Galenic medicine. ${ }^{11}$ The growing success of health regimens and diet books was largely due to their accessible presentation. These were "practical" texts, which were themselves objects of a "practice." 12 They allowed the reader to take care of his own health without consulting a doctor, and to understand the factors affecting his well-being. Dietetics, in particular, did not require the specialized knowledge of the other branches of medicine (anatomy, pharmacology, and surgery) and was embedded in the literary, philosophical, social, and moral culture of the day.

The interest in pragmatic ways to live a long and healthy life downplayed the religious connections between old age and the afterlife; indeed, the discourse on the care of the self, along with its emphasis on the here and now, had unmistakable Epicurean and Stoic overtones. ${ }^{13}$

\footnotetext{
10 De probis pravisque alimentorum sucis, in Galen, Opera omnia, vol. 5, pp. 755, 757 . My translation.

11 Cf. Siraisi, The Clock and the Mirror, pp. 70-89.

12 Foucault, The Use of Pleasure, p. 12.

13 See chapter 4, section 3 .
} 


\section{Petrarch}

Well before the second half of the fourteenth century, elder members of the wealthy classes in Europe were concerned with preserving their health. Following classical models, Avicenna had included age among the dominant factors of health; likewise, the organization of some diet books around the ages of life took on a more formal structure. ${ }^{14}$ Some authors focused more on medical ways to prevent the process of aging from accelerating. One needs only to think of Roger Bacon's Libellus de retardandis senectutis accidentibus (circa 1236) paraphrased in Arnaldo Villanova's De conservanda juventute et retardanda senectute (ca. 1309-11), ${ }^{15}$ of Bernard de Gordon's Tractatus de conservatione vitae humanae (1308) that integrated old age into the management of health, ${ }^{16}$ or of Guido da Vigevano's Liber conservationis sanitatis senis (1335) written for older men going on pilgrimage to the Holy Land. ${ }^{17}$

In contrast to these medical works, Petrarch's remarks on his health and diet in his Letters of Old Age (Rerum Senilium Libri, conceived in 1361, at age fifty-seven) cross the boundaries between medicine, moral philosophy, religion, history, and literature. In his correspondence (Sen. III, 5; $\mathrm{V}, 3$ ) and his Invective contra medicum, ${ }^{18}$ he often criticizes doctors' corruption and ignorance, and pokes fun at their pretentious jargon, but his attacks target bad practitioners and never question the value of medicine. In fact, he held Hippocrates and Galen in as much esteem as Cicero. As he grew old, he portrayed himself as physically fragile, but morally tougher at bearing ills, as if time had opposite impacts on his body and his mind.

Book XII of the Letters of Old Age contains only two letters to the Paduan physician Giovanni Dondi, dated July and November 1370, which constitute Petrarch's most elaborate comments on his health in his later years. In the first letter, the sixty-six-year-old writer focuses on ways to recover from a yearlong illness that so affected him that he had not been able to move around for many days. In his own words, he felt like "a sad weight,

14 See Marilyn Nicoud, Les Régimes de santé au Moyen Age. Naissance et diffusion d'une écriture médicale (Rome: Ecole française de Rome, 2007), vol. 1, pp. 193-99.

15 On these books, see Michael Goodich, From Birth to Old Age. The Human Life Cycle in Medieval Thought, 1250-1350 (New York: University Press of America, 1989), pp. 159-61.

16 See Nicoud, Les Régimes de santé au Moyen Age, vol. 1, pp. 185-238.

17 Guido da Vigevano's Liber conservationis sanitatis senis (1335), Bibliothèque Nationale, Paris, fonds latin 11015 .

18 Invective contra medicum, in Opere latine di Francesco Petrarca, A. Bufano, ed., vol. 2 (Turin: Unione tipografica-editrice Torinese, 1975). 
burdensome to others, hateful to myself" (Sen. XII, 1, p. 442). ${ }^{19}$ Two conceptions of health are at stake: a medical perspective aiming at healing an aging body, and a holistic notion of spiritual wellness. Both views are linked to Petrarch's eating and drinking habits: whereas Dondi's prescriptions are about dietetics, Petrarch promotes a diet ethics: he sees his diet as a spiritual exercise "captured live" by which, in Foucault's words,

men not only set themselves rules of conduct, but also seek to transform themselves, to change themselves in their singular being, and to make their life into an oeuvre that carries certain aesthetic values and meets certain stylistic criteria. ${ }^{20}$

For Petrarch, these "aesthetic values" go along with ethical and religious concerns. Book XII's two letters focus on three of Dondi's prescriptions. First, the doctor forbids his patient to drink water, and instead recommends wine. Second, he finds Petrarch not strong enough to fast on a regular basis. Third, Dondi recommends abstaining from fruits that are dangerous at any age. Several centuries later, this last prescription strikes a strange note, but most Renaissance diet books contended that fruits putrefy in the stomach, generating phlegm; as a result the blood is unable to absorb their moisture. At first glance, Dondi's three prescriptions seem disparate, but from a medical perspective they are, in fact, totally coherent since they epitomize the three types of elements ingested by the body according to the Hippocratic-Galenic tradition: air (represented by Petrarch's words), food (mentioned in absentia by the discussion on fasting), and liquid (suggested by water and wine). ${ }^{21}$ Dondi's prescriptions convey his medical knowledge of nutrition, but Petrarch complains that they focus mostly on his patient's age, rather than his overall condition (Sen. XII, 1, p. 467/ Lettres, vol. 4, p. 37). His objection makes perfect sense. Any learned contemporary would have immediately understood the reason for the physician's first advice, since wine warms up a body that is becoming colder in the winter of life. Moreover, wine has strong digestive powers, well indicated for an older (weaker) stomach. In Galen's De Sanitate tuenda, the daily meals of Antiochus and Telephus included wine. Isidore of Seville's widespread Etymologiae added a linguistic confirmation of wine's beneficial effect. Vinum is so named, Isidore notes, because

\footnotetext{
19 "pondus mestum, grave aliis, odiosum michi." (Lettres, vol. 4, p. 21).

20 Foucault, The Use of Pleasure, pp. 10-11.

21 Galen, De placitis Hippocratis et Platonis, in Opera omnia, vol. 5, p. 6o5. See also Galen's comments on Hippocrates's De humoribus 3, 3 in Opera omnia, vol. 16, pp. 357-63.
} 
when it is drunk it fills the veins (venas) quickly with blood. Furthermore, in true Galenic spirit, Dondi believes that water and fruit are cool; consequently both are detrimental to an old man with a cold body. As for the second of Dondi's prescriptions, old men are frail and cannot endure prolonged hunger.

In contrast to Dondi's theoretical knowledge, Petrarch relies largely on self-observation. He concedes that his body has grown old and has consumed some of its natural heat, yet it is still warm. Fasting is not dangerous for him because he is used to it; moreover, it stimulates his mind and is a healthy, useful, and holy practice. One needs only to think of the Church fathers who lived in the desert, fasting on a regular basis; some became centenarians. Turning to Dondi's second prohibition-fruit-Petrarch provides Dondi with a few historical examples of their beneficial effects. Finally, why should he drink wine, which "produces the gout, maintains it, and makes it recur by the mere smell of it, so to speak?" (Sen. XII, 1, p. 447/ Lettres, vol. 4, p. 35). Other letters of the Seniles similarly stress the dangers of alcohol, and Petrarch's "addiction" to water, in old age. ${ }^{22}$ Alcohol is often blamed for shortening life; in addition, any Christian reader would have been sensitive to Petrarch's criticism of wine since the letter reminds Dondi of the disastrous moral consequences of alcohol on Noah, who reportedly first made wine. The letter also points out that, according to Saint Paul, wine can provoke sin (Sen XII, 1, pp. 448-9/ Lettres, vol. 4, p. 37).

Foucault saw the care for the self in Greco-Roman Antiquity as a practice of freedom, yet he did not take into account the ways in which medical judgments are integrated into systems of action in relation to pathology. This would require an investigation of the different justificatory mechanisms whereby medical truth claims are sustained according to certain criteria. Too often, as Petrarch notes, doctors eagerly control the slightest details of their patient's daily life. His remarks on his diet strike a classical note of practical wisdom and sobriety, while also conveying his Christian devotion. His austere meals, he contends, fortify his spirit and render him capable of coping with illness.

Petrarch's second letter to Dondi focuses on a process of reconciliation:

we both have wanted the same thing, however differently, you from doctors and I from God, namely that whatever remains of life I spend in good health,

22 See Sen. III, 9; III, 13; V, 3. 
so that life itself be happier and longer-even though when we defer it for long, if anything here is long, we must still die. (Sen. XII, 2, p. 475 $)^{23}$

Since Plato's Symposium, banquets are traditionally associated with conviviality, but in Petrarch's letter, a discussion on a sober diet proves to be the best recipe for friendship. "I see you in a twofold role," he writes to Dondi, "the friend and the doctor. With a friend I so agree on everything that there can be nothing you think or like that I do not think and like immediately." With doctors, however, he was more cautious; his reservations on important matters came from "prolonged experience and close observation.” (Sen. XII, 2, p. 453/ Lettres, vol. 4, p. 47). Cicero-a major model of the Letters of Old Age-stressed the natural connection between old age and friendship. ${ }^{24}$ In the same spirit, Petrarch's second letter to Dondi in book XII conveys the harmony of the protagonists' respective views: it is true that wine disturbs the mind and plagues the body with illness, yet it may give some comfort if drunk with moderation, Petrarch concedes. Likewise water may be harmful to an old stomach but can also be part of a healthy regimen at any age of life since Hippocrates praises it. For food as for drink, the crucial point is to avoid excess. In the end, the writer's defense of sobriety and his emphasis on personal habits fully comply not only with a Stoic ideal of life but also with the medical principles of his time.

The reconciliation of the doctor's and the humanist's views takes its full meaning in the intellectual context of the day. Medicine and the liberal arts had institutional relations in universities such as Bologna, Padua, and Florence, since both fields had therapeutic goals and ethical concerns. On the one hand, Hippocratic treatises argued that physicians should be philosophers since they are concerned with both the body's and the mind's well-being. On the other hand, Plato and Aristotle contended that philosophers are doctors because they aim at healing spiritual and moral illnesses. ${ }^{25}$ During Petrarch's youth, Peter of Abano, then a prominent teacher at Padua, stated that medicine and philosophy were sisters, and that medicine was superior to philosophy because of its usefulness. ${ }^{26}$ The

23 "Licet enim aliter atque aliter a medicis ego a Deo; ambo tamen unum volumus, ut quodcunque scilicet vite restat sanus degam quo vita ipsa sit letior longiorque, quanquam, cum diu, siquid est hic diu, distulerimus, moriendum sit." (Lettres, vol. 4, p. 103).

24 See the opening remarks of Cicero's De Amicitia.

25 See Plutarch, Préceptes de santé, in Traités 10-14, ed. J. Defradas, J. Hani, and R. Klaert (Paris: Les Belles Lettres, 1985), vol. 2, pp. 93-135.

26 N. Siraisi, Arts and Sciences at Padua. The Studium of Padua before 1350 (Toronto: Pontifical Institute of Medieval Studies, 1973), pp. 152-55. 
universities of Padua and Bologna had put medicine at the top of the curriculum, above metaphysics, rhetoric, and grammar, but Petrarch had obviously another view on this question. His objections to Dondi's prescriptions proved so persuasive that two further letters dated 1371 and 1372 report that the doctor had found inspiration in his patient's moral and religious concerns (Sen. XIII, 15 and 16). Ironically, Petrarch's reactions to standard medical treatment improved the doctor's health of mind.

For Foucault, the care for the self "implies a certain manner of acting visible to others," that is a "relationship to the other to the extent that ... one must listen to the teachings of a master." ${ }^{27}$ In Petrarch's letters, it is the patient rather than the doctor who takes on this pedagogical role. In some way, book XII's two letters remind physicians of their professional duties as defined by Plato's Laws (IV, 720b-e): a conscientious doctor does not limit himself to writing prescriptions, but enters into conversation with the patient, listens to his observations and daily habits, and leads him to the right kind of life. An effective health regimen acts upon an individual's body and soul, trains the will, enhances moral firmness, and implies a way to reform one's self. In a later letter dated August 28, 1371, Petrarch informed Dondi that he no longer suffered from the fever, but still felt weak, and would wait for God's help since Jesus is the only doctor able to make us healthy (Sen. XIII, 15).

The aging humanist saw health as a form of spiritual well-being founded on medicine. Commenting on the contentions of Aristotle and Terence that "old age is a disease," he observes in yet another letter: "nor do I reject this maxim, provided that one point is added to it: that old age is a disease of the body but the health of the mind." (Sen. XVII, 2, p. 646). He distinguishes the ages in terms of opinions rather than physical condition, as did Galen and Dondi:

not that I would call old age wretched in itself, but rather happy unless deluded by the errors of earlier ages. Nor even so is it wretched if only it rises up, and, shaking off the vanities, it gains wisdom and true opinions, albeit at the end of life, as Plato puts it. If this is what philosophers thought, what ought we to think, to whom has been granted the attainment of wisdom, virtue, and salvation... (Sen. XII, 1, p. 441/ Lettres, vol. 4, p. 17).

His Letters of Old Age represent him as a Christian Ancient that old age has set "right," in his own words (Sen. XVIII, 1, p. 672). Old age adds a feeling of urgency to the preparation for the afterlife, while also inviting consid-

27 Foucault, "The Ethic of Care of the Self as a Practice of Freedom", pp. 4, 7. 
erations on the care of the self. Following Cicero's and Seneca's examples, his later letters praise a life in a peaceful, rustic retreat, away from the worries and tensions of the city, in the company of a circle of friends and books. His dual concern for literary immortality and salvation allowed him no time for laziness or daydreaming; likewise, he considered sleep as a waste of time that distracted him from praying and writing. Yet the pleasure he took in exchanges and conversations increased over the years, as evidenced by his intense epistolary activity. Such pleasure involved a "conversion to oneself... thanks to which, escaping all dependency and enslavement," 28 Petrarch could return to himself in order to reach God. In addition, his emphasis on his age served his literary reputation well. In the words of Seneca (a major source of inspiration of the Seniles), he felt "that age ha[d] done no damage to [his] mind, though he [felt] its effects on [his] constitution." For the aging Petrarch, as for Seneca, the "mind [was] strong and rejoice[d] that it ha[d] but slight connection with the body" (Ad Lucilium XXVI, 2, p. 187). ${ }^{29}$ In some ways, growing old was Petrarch's way of becoming ageless in the eyes of posterity.

His Letters of Old Age elevate him to a status similar to illustrious elders ranging from Cicero's Cato the Elder in De Senectute, to Seneca, and Gartius - Petrarch's own paternal great-grandfather — who peacefully passed away in "the one hundred and fourth year of life," with "no suffering either of body or mind, and speaking of nothing except God and goodness." ${ }^{30}$ Gartius's faith had protected him from the woes of old age; he epitomized Petrarch's own Christian and classical ideal since he died on his birthday (as did Plato, but twenty-three years shy of Gartius's age), and uttering David's last words. He was a "very holy man and of considerable ability," Petrarch commented, equally consulted about affairs of the state and private matters because of his expertise, fair judgment, and wisdom. Such was also the image of himself that Petrarch tried to convey in his Letters of Old Age.

28 Michel Foucault, The History of Sexuality, vol. 3, The Care of the Self, trans. R. Hurley (New York: Vintage Book, 1986), p. 57.

29 Seneca, Ad Lucilium. Epitulae Morales ed. and trans. R. Gunmere (Cambridge, Mass.: Harvard University Press, 1953), vol. 1, pp. 186-87. All further references are to this edition and are incorporated into the text.

30 To Giovanni Colonna in Letters on Familiar Matters, (Rerum Familiarium Libri), ed. and trans. Aldo Bernardo, vol. 1, VI, 3, pp. 301-302. "quarto ac centesimo etatis anno... nulla corporis aut animi molestia, nil nisi de Deo et de virtutibus loquens...," Le Familiari, vol. 2, p. 66. In Rossi's Latin edition, the name of Petrarch's great-grandfather is Gartius, but in Bernardo's English translation his name is "Gattius." 


\section{Ficino and Zerbi}

For Petrarch, the care for the self is a strategic game, it is part of a process of self-representation through a number of daily practices closely linked to intellectual and religious concerns. From the end of the fifteenth century on, however, the increasing number of elderly men from the wealthy classes created a market for issues related to longevity. Indeed, Gabriele Zerbi and Marsilio Ficino were consciously responding to a need when they each published health regimens for the elderly in 1489. Although they were not the first to write such books, they were aware that keeping a sound mind in a healthy body in the winter of life was a pressing concern for a large number of contemporary learned men and members of the upper classes. Both acknowledge their debt to earlier medical authorities (including Galen and Hippocrates) while stressing their originality. In the dedication of his Gerontocomia (On the Care of the Aged), Zerbi says he undertook his work because "few of our recent physicians have attempted the task" of speaking of the care of the elder, and those who did "have touched rather lightly upon the subject within narrow limits and with excerpts merely." ${ }^{1}$ A famous professor of anatomy and a practicing physician in Padua, Rome, Venice, and Bologna, Zerbi had excellent reasons to boast about his competence. Ficino adopts a similar self-congratulatory tone in his De Vita libri tres: "I am the first to attend as a physician sick and invalid scholars," he claims in book I's first chapter (I, 1, p. 109). ${ }^{32} D e$ Vita's lasting success is evidenced by its thirty editions between 1489 and 1647. Book I focuses on the health of the intellectual, book II on longevity, and book III elaborates on the conservation of life in the perspective of Platonic astral magic.

Zerbi's and Ficino's treatises combine literary quotations and commonplaces with medical, biblical, historical, and philosophical references. Both authors target readers well beyond the narrow circle of physicians-humanists, members of the Church, and people from the

31 Gabriele Zerbi, Gerontocomia: On the Care of the Aged. ed. and trans. R. Lind (Philadelphia: American Philosophical Society, 1988), pp. 20-21. All further references are to this edition and are incorporated into the text. For the Latin edition (Rome: Eucharius Silber, 1489), see the Bibliothèque Nationale de France's Gallica website: http://gallica.bnf. fr/ark:/12148/bpt6k584977

32 Marsilio Ficino, Three Books on Life, ed. and trans. C. Kaske and J. Clark (Binghamton: Medieval and Renaissance Texts and Studies, 1989). All further references are to this edition and are incorporated into the text. The Roman number indicates the book number, the second number refers to the chapter number, and the third one to the page number. 
liberal professions - and provide their learned but somehow uninformed audience with accessible explanations of medical notions. Obviously, their readers had the financial means and the leisure to take care of their health, yet neither Ficino nor Zerbi had any desire to impart their instructions to "lazy and indolent" people. "For why should we wish those people to live long who do not even live, as if we were nourishing drones and not bees?" Ficino asks:

Nor do I wish them to be divulged to people who are dissolute through their corrupt passion for pleasures, fools who far prefer the brief pleasure that lasts only a day; nor disclosed to the wicked and unjust whose life is the death of good men; but only to prudent and temperate people of sophisticated intelligence who will benefit mankind, whether in the private or the public sphere. (II, 1, p. 167)

As Ficino's and Zerbi's respective dedications make clear, people who hold important positions in the public sphere have an obligation to pay attention to their health. In Plato's Phaedrus, Socrates says that the care for the self is the precondition for being involved in the affairs of the polis. For Foucault, this means that only men who can exercise self-control are capable of governing others and of having a successful political career. To his view I would like to add that Socrates's observation also reminds us that the well-ordered soul and the well-ordered polis have similar structures. Likewise, Ficino dedicates book I: On a Healthy Life to Lorenzo de Medici, and book II: On a Long Life to Filippo Valori, "Florence's most upright and noblest citizen" (p. 165) who bore the expenses of publishing De Vita. Book III: On Obtaining Life from the Heavens is dedicated to Matthias Corvinus, King of Hungary. For these powerful patrons, Ficino defines the motivations for a long and healthy life: first, praising God as long as possible; second, studying, for as Hippocrates's first aphorism points out, "Ars longa, vita brevis"; Ficino concurs that "Art is long, and we can only attain it by a long life" (II, 1, p. 167). As he is quick to point out, such lifelong efforts should contribute to the collective welfare. In a similar way, Zerbi dedicates Gerontocomia to his patron, Pope Innocent VIII, because a long life with a sound mind in a healthy body is a prerequisite for his important spiritual mission. ${ }^{33}$

33 Zerbi never alluded to religion in the course of his discussion on health. Whether his silence was a matter of prudence or simply a will to focus on a medical perspective is open to debate. 
De Vita libri tres has been called the first treatise "to reason medically at any length about the paradoxically positive intellectual value of melancholy" (p. 23). People neglect health because of ignorance and carelessness, Ficino contends, yet intellectuals have special medical needs since they are the most prone to "black bile" or melancholy. The treatise's syncretism has attracted a wide range of comments, ${ }^{34}$ but its discussion of longevity has been neglected, although it is the focus of De Vita's book II. To be productive, a scholar should be in good health (book I), Ficino argues; moreover, a long life gives him the opportunity to perfect his knowledge and acquire sufficient experience (book II).

Throughout book I On a Healthy Life (De Vita sana), psychology mingles with hygiene and pharmacology, while astrology comes in incidentally. Book I presents melancholy as the physical basis of intelligence and genius; yet when excessive, it "vexes the mind with continual care and frequent absurdities"; it "unsettles judgment," and drives scholars to "depression and even sometimes to folly." In addition, learned people are prone to suffer from a surplus of phlegm, which "suffocates the intelligence" (I, 3 , p. 113). Along with phlegm and black bile, Ficino warns the reader of three major life threats: incontinence in sexual matters that weakens the brain; satiety in food that "dulls the mind"; and large amounts of wine which fills the head with "bad fumes." A good digestion is especially important to keep a clear mind (I, 11, p. 137). The book also dwells on occupational hazards of scholars such as sleeping after sunrise, a habit that adversely affects the mind (I, 7, p. 125); headaches and insomnia (I, 16; I, 24, p. 143, 157); dimness of vision (I, 16, p. 143); and dullness and forgetfulness (I, 25, p. 159). De Vita sana ends with a statement similar to Petrarch's book XII of the Senilium: medicine takes care of the body, moral discipline teaches appropriate behavior and is the basis of a serene mind, but only religion can lead the scholar to spiritual well-being and true joy (p. I, 26, pp. 161-63).

Book II On Longevity (De Vita longa) combines ancient theology with medical, Christian, and occult comments. ${ }^{35}$ Longevity is not "something the fates promise once for all from the beginning," Ficino contends, but is "procured by our effort" (II, 1, p. 167). He dwells on the foods that help

34 See the introduction of the edition of Ficino's De Vita, pp. 2-23.

35 Ficino wrote book II mostly to please a Christian audience that found book III's Platonic astral magic suspicious. See Brian Copenhaver, "Scholastic Philosophy and Renaissance Magic in the De Vita of Marsilio Ficino," Renaissance Quarterly 87, 4 (1984), pp. $5^{23}-54$ on Ficino's magical, astrological, and Christian perspectives as well as on the Church's criticism of this syncretism. 
sustain the aged scholar's vital heat and maintain the quality of his blood. Since digestion is, as Galen contends, the "root of life," and longevity is a matter of a balanced proportion of innate heat and moisture, Ficino applies the standard medical principles of moderation and cure by the opposites. Endorsing Galen's division of old age into three phases, Ficino observes that people in their fifties should have a diet different from those in their seventies; likewise, decrepit intellectuals need a regimen adapted to their condition. In addition, "pleasant and somewhat hot" odors can extend the life span (II, 7, p. 185). Ficino might have read in the Book of the Apple and of Death (Liber de Pomo et Morte) that Aristotle's life was prolonged by the odor of an apple. ${ }^{36}$ Moreover, he was certainly familiar with Diogenes Laertius's story about Democritus who was about to die at the time of a festival in his hometown. When the citizens asked the philosopher not to die until they had completed the celebration and the banquets, Democritus remained alive for four days, by smelling Attic honey in a cup, as if he were still making fun of humankind. Other accounts say that he survived on the smell of baking bread. ${ }^{37}$ Isidore of Seville's etymological dictionary gave Ficino's learned readers a linguistic confirmation of the need for sensual pleasures in old age: according to this source, the Latin senectus (old age) comes from sensus (the sense), because human blood becomes colder as the years go by, and there is a general waning of sensual acuity. ${ }^{38}$ Like other Renaissance authors of health regimens for the elderly, however, Ficino recommends continence in sexual matters. Moreover, for the aged, he finds the color green especially pleasing (II, 14, pp. 203-5). Music, an important element in Pythagorean therapeutics, is also most effective for the conservation of health and the prolongation of life.

Book II also contains occult recipes for the revitalization of aging scholars, some of which come directly from Roger Bacon's Libellus de retardandis senectutis accidentibus (ca. 1236). Food made of potable gold is highly recommended because this metal is the "most safe from decay" (II, 10, pp. 195-97); the mixture should be prepared "when the Moon enters Leo, Aries or Sagittarius and aspects the Sun or Jupiter," along with "the whitest sugar dissolved in rose-water" (II, 10, p. 195). Other recipes include

36 Liber de Pomo et Morte, ed. D. S. Margoliouth in Journal of the Royal Asiatic Society, 1892, pp. 187-252.

37 Diogenes Laertius, Lives of Eminent Philosophers, ed. and trans. R. D. Hicks (Cambridge, Mass.: Harvard University Press, 1958-59), Book 9, pp. 39-43.

38 Isidore of Seville, The Etymologies of Isidore of Seville, ed. and trans. S. Barney (Cambridge: Cambridge University Press, 2006), XI, 2. 
sucking the milk of a "healthy, beautiful, cheerful, and temperate" young girl. The blood of a "willing, healthy, happy, and temperate" youth can also invigorate a man who is over seventy years old, or at the climacteric age of sixty-three (II, 11, p. 197).

Book II's final remarks on longevity epitomize Ficino's syncretism. Summing up his observations on this issue, the author concludes that Bacchus preserves youth by offering humankind three presents: the "hills exposed to the Sun"; on these hills, "the sweetest wine; and in wine "perpetual freedom from care." Bacchus's brother Phoebus also makes human beings three gifts to preserve youth: "daylight; then herbs sweetly smelling with the warmth of daylight," and the "lyre and perennial song." To these divine presents, Ficino adds his own ones: frugality (parcitas) and moderation (temperantia) in every necessity of life. The constant care of the body and mind is essential to keep far off "that imbalance of humors that is the cause of quick old age and untimely death," yet only God will help the aged scholar to live a long life for the sake of "the human race" and God himself (II, 20, p. 235).

The third and final book of Ficino's treatise belongs to a climate of religious and social anxiety that turned to astrology to explain human destiny in relation to the laws of the universe. Since a long and healthy life is a matter of harmony with oneself (based on a good proportion of heat and moisture) and with the heavenly bodies, book III discusses ways to tap into the cosmic forces that govern the world so as to prolong his readers' days beyond their predicted term. The wise scholar thinks and acts with a view to the cosmos, and does not let himself become detached from a totality of which he is a part. Although Jesus is at the center of his prayers, studies, and manner of life, he knows that the pagan gods and the celestial bodies affect his body and mind. As he grows old, he follows his "natural bent" to find the lifestyle most suitable to him (III, 24, p. 377). He should therefore "investigate exactly what region [his] star and [his] daemon initially designated [him] to dwell in and cultivate, because there they will favor [him] more" (III, 23, pp. 371-73). In addition, readers should imitate the celestial bodies, and since they "were engendered" by their movements, they should make similar motions to be preserved (III, 23, p. 373). ${ }^{39}$

39 This kind of exercise recalls a passage of Plato's Timaeus in which the soul brings its inner movements into accord with the movements and harmony of the world. 
The publication of Gabriele Zerbi's Gerontocomia in 1489-the same year as Ficino's treatise-marks another milestone in establishing the elderly as an object of medical research. The work has the same two-fold objectives as Ficino's De Vita (first, to slow down the ravages of old age, and second, to comfort and maintain the elder's current condition of tolerable health), but offers a much more systematic and meticulous discussion of the care of the aging self.

From the start, Zerbi prepares his reader to confront senescence without any value judgment. Old age begins sometime between the thirtieth and fortieth year of human life, he notes, and extends to the fiftieth or sixtieth year. Following Galen, he distinguishes three periods in old age. In the first phase, the individual keeps some qualities from the previous age of his life (beauty, flowering, constancy) since his body is still hot and dry. In the second stage, however, he already sees a few signs of his future decrepitude, because his body becomes colder and drier (and accidentally humid). This period is "something like a middle equidistant" between the first and the third phases in terms of heat and moisture. Men in this phase of old age exhibit "constancy, strong understanding, and wisdom;" they have lost their previous playfulness and sexual desire since they are colder and drier than in their youth. The planet Jupiter dominates this second period, "providing the person with guidance for about twelve years" (I, p. 30). After this time of peace and religious good works comes decrepitude, along with illnesses, infirmities, and sadness. This melancholic and final phase of old age is placed under the sign of Saturn. The decrepit man's understanding dwindles away, and his memory decreases because cold and dryness now predominate in his body. In Latin, old men are called senes, Zerbi notes, because they "know not" (nesciant). Moreover, they are decrepit, because "they can neither move nor make any creaking (crepitum)" (I, pp. 31-32). He carefully lists the physical weaknesses associated to decrepitude: the teeth fall, the vision dims, hearing becomes bad, and the taste dulls; the skin wrinkles, and movements are more difficult. The greatest of all these woes is senile dementia (I, p. 31).

Throughout the treatise, empirical observations complement standard Hippocratic-Galenic principles. There are, for instance, early signs of longevity: a young man in good physical condition, and not overweight, has a good chance of living a long life. Other signs are less visible: those who have many teeth, "especially more than thirty-two," are said to be longerlived (VII, p. 63). One should also take into account the influence of the planets when discussing longevity. 
At the center of every Galenic treatise on the conservation of healthwhether in old age or earlier-is the regimen or governance by the so-called six "non-naturals." Most of them date back to the Hippocratic treatise, Air, Water and Place; some were attributed to Galen, and later reworked by his Latin and Arab interpreters. Let's look briefly at these principles. The non-naturals are factors that are partly psychological, partly physiological and environmental; yet they are neither part of our nature (the "naturals" being temperament, humors, age, region, climate, etc.), nor diseasecausing (the "contra-naturals" being illness, hereditary factors, etc.), but are necessary to life and health. ${ }^{40}$ For Zerbi and his contemporaries, the six res non naturales comprise, in this specific order: air, food and drink, motion and rest, sleep and wakefulness, retentions and excretions, the passions and emotions. The second "non-natural" factor-food and drink-comprises the most important part of Renaissance regimens. The substances ingested by the body were endowed with elementary qualities; relatively stable conventions attributed particular qualities to certain foodstuffs. Hippocratic and Galenic treatises therefore provided instructions for selecting foods with the appropriate qualities. Broadly speaking, health resulted from a proper balance of the substances ingested by the body, all of which were themselves endowed with elementary qualities. Health was maintained by a diet of foods whose "complexion" was similar to the individual's own; health was restored via foods with qualities suited to the invalid, or the elderly. Nutritional advice was usually rooted in a conservative tradition, yet the details of the geriatric diet as well as the qualities attributed to specific food were a matter of ongoing discussion.

Zerbi's attention to detail is striking. He meticulously examines the best time for the elder's meals, the selection of wine, and the quality of meat. He reviews the parts of birds, fish, and mammals most easy to digest, and enumerates the types of milk, vegetables, bread, and spices that will help restore the aged body's heat and moisture. His discussion of the other five non-naturals has the same precision. Closely following Hippocratic and Galenic principles, he describes the best orientation for the elder's house, recommends a bright room that should be kept warm in winter, fresh in the summer (first non-natural). For the third non-natural (rest and motion), Gerontocomia prescribes light physical exercises such as massages and hot baths. The treatise also pays careful attention to the elder's clothing, the quality of his bed, and the number of hours of sleep.

40 See Nicoud, Les Régimes de santé au Moyen Age, vol. 1, pp. 1-11. 
In discussing the fifth non-natural (retentions and excretions), Zerbi, like other contemporary doctors, bans sexual intercourse. His discussion of the sixth one (passions and emotions) warns of the dangers of anger and anxiety, because passions and strong emotions accelerate the negative effects of aging. The old man should actually avoid any type of excess-physical and intellectual - given his overall frail condition. Zerbi also recommends the constant presence of a qualified and carefully trained caregiver (the gerontocomos) at the elder's side (15-40, pp. 87-247).

Zerbi's further advice also follows the Galenic model: he advocates respecting the elder's habits, for instance, and the need for social and intellectual stimulation. Some recommendations are similar to Ficino's in this respect: music and activities enhancing sensual and mental pleasures are beneficial to a healthy old age since they bring joy, serenity, and hope (42, pp. 265-67). Finally, like Ficino, Zerbi had read Roger Bacon and suggests potable gold, human milk, and human blood to strengthen the old man. He is, however, more skeptical than Ficino as to the effectiveness of these recipes.

To what extent did Ficino's and Zerbi's elder contemporaries follow the advice dispensed here? We cannot say, given the absence of documents. Moreover, in contrast to Galen's frequent remarks on his daily habits, neither Ficino nor Zerbi tell us whether they personally followed their own medical advice. Ficino had a long life by the standards of his time and passed away a few weeks before his sixty-sixth birthday. Zerbi's violent end, on the other hand, was the indirect result of the gap between medical prescriptions and practice. In October 1504, the Venetian ambassador at the court of the Sultan pressed Zerbi to cure the pasha Zander at the Ottoman court of Bosnia. One month later, his mission accomplished, Zerbi was heading back to Italy with his son, loaded with precious stones as a token of the pasha's gratitude, but his patient immediately resumed his lavish style of life and died. The pasha's sons stopped Zerbi at the Dalmatian border, robbed the two travelers, and sawed them. Although it is difficult today to assess the impact of health treatises on Renaissance people's daily regimens, the popularity of these works confirms a broad interest in the care of the self. Ficino's De Vita libri tres went through enough editions to earn him a place in Sarton's list of seventy-seven best-selling authors of scientific incunabula. ${ }^{41}$

41 Ficino, De Vita, p. 3. 
Like Petrarch's letters to Dondi in book XII of the Letters of Old Age, Zerbi's Gerontocomia belongs to a presentation of the self in what Foucault calls "the unfolding of everyday life," thereby "attesting not the importance of an activity but the quality of a mode of being." ${ }^{42}$ Foucault's characterization of the care of the self in Hellenistic and Roman texts corresponds to Zerbi's discussion of old age: Gerontocomia's health regimen is a matter of exercise and continuous vigilance that closely links the ethical question of how an aging man should behave to the medical question of what old age truly is. Zerbi's detailed advice recalls Lucilius's request to Seneca to recount his day, hour by hour. Seneca accepts because it forces him to live "under the scrutiny of the other," recounting the day just past, "the most common day possible, whose value lies precisely in the fact that nothing happened that could divert him from the only important thing for him: to care for himself." 43 Just like Seneca's account, Zerbi's advice on the care of the aging self is a way of cultivating some kind of relationship of oneself to oneself. Far from being a narcissistic activity, these practices fashion the aging self, guide him in the process of becoming capable of governing himself and others. Moreover, they take their full meaning once questions related to health and longevity are replaced in their cosmic context.

\section{Cornaro}

Books on health care submit the body to daily scrutiny and control. As such, Zerbi's and Ficino's treatises participate in a process of secularization that downplays old age's connection with death and the afterlife. As both authors made clear, a regimen is a pragmatic device to mold behavior; it opens up a path to a new way of being and transforms our vision of the world. No writer went further in this direction than the Venetian patrician Luigi Cornaro (1467 or 1475 to 1566 ?) in his Trattato della vita sobria, first published in 1558.44 Staying healthy is the goal of his daily life and his philosophy. Pointing to his age at the opening of each revised edition of his treatise, he claimed to be the living proof of the success of

42 Michel Foucault, Dits et écrits, vol. 2 (Paris: Gallimard, 2001), p. 1247. My translation.

43 Ibid., p. 1247.

44 Luigi Cornaro, Trattato della vita sobria (Venice: no publisher's name, 1558). See also Discorsi della vita sobria (Venice: Brogiollo, 1620). Discourses on the Sober Life (Discorsi Della Vita Sobria) Being the Personal Narrative of Luigi Cornaro (1467-1566, A.D.), no translator's name (New York: Crowell, no date). Further references are to this last edition and are incorporated into the text. 
his method. But how old was Cornaro at the time of his death? Was he in his seventies, as some critics suggest; in his late nineties, as he claimed; or over one hundred years old, as his admirers proclaimed? He was quick to boast about his longevity, probably attributing to himself a few extra years. He became a legendary figure and his elevated social status promoted favorable responses to his self-portrait as a sober senior.

Cornaro seemed immune to the negative effects of senescence. At age ninety-one he reports that he writes eight hours a day and goes out frequently on foot or on horseback. He sings with as much strength and delight as in his twenties. (Singing was considered a physical exercise that improved breathing.) Four years later Cornaro published the fourth and last revised edition of his treatise. His lifestyle is similar to Antiochus in Galen's De Sanitate tuenda, but he also spends time with his eleven grandchildren, and sees his offspring as a form of immortality. His property in the Venetian countryside is in his likeness: prosperous, friendly, and harmonious. The older Cornaro grows, the healthier he feels, physically and mentally. His memory is excellent, his dynamism and cheerfulness are outstanding. Nothing can alter his mood, not even the prospect of death. Della vita sobria was "in everybody's hand," according to Girolamo Cardano. As Nancy Siraisi observes, "its appeal, no doubt lay in a moralizing tone appropriate to midcentury taste and in the universality and simplicity of the regimen prescribed." ${ }^{45}$ Cornaro's treatise is a pragmatic and accessible guide, with few technical medical explanations; the astrological and occult considerations that appear in Zerbi's and Ficino's discussions are conspicuously absent.

Cornaro's secret for staying forever young is simple and straightforward: a sober diet and a regular life. The treatise reinforces contemporary dietary practices through strict discipline and control. In language suited to a conversion experience, Cornaro recounts his decision to change his daily habits. As a young man he had indulged in rich food and luxuries, but having reached the age of thirty-five, the effects of his intemperate life began to show themselves: colic, gout, a continual fever, an upset stomach, and a perpetual thirst threatened his life. His case was far from exceptional. Lavish banquets had grown out of hand in mid-sixteenth-century Italy, sumptuary laws were enacted to regulate their excessive expenses and to limit the number of guests. Cornaro sought medical help and found sound physicians who insisted that his only cure lay in reforming his way

45 N. Siraisi, The Clock and the Mirror, p. 79. 
of life. On former occasions he had rejected such advice, but this was no longer an option, unless he was resigned to an early death. This was the turning point. He abandoned strong wines, meats served with rich sauces, and fruits. Interestingly, Cornaro changed his way of life at exactly the same age the poet of the Divina Commedia underwent his religious conversion. The thirty-fifth year is the middle of a human life span, as the first line of Dante's poem put it. The reference is to Psalm 90:10, which offers the simplest scheme of the division of life into two parts: youth, up to age thirty-five or forty, old age up to age seventy or eighty. ${ }^{46}$

The physicians urged Cornaro to restrict his diet, both solid and liquid, to twelve ounces of food and fourteen ounces of wine per day. This would add up to about one thousand calories. ${ }^{47}$ Recent research has shown that a low-calorie diet slows down the aging process, but Cornaro had of course other sources of reference: the Bible speaks of patriarchs who lived hundreds of years and were continent in their diet; they knew no sauces, rich food, or similar culinary extravagances. In a few days, Cornaro began to see that his shattered health was improving. After less than one year of sober eating and drinking, he found himself totally free from his ailments. The change was not only physical but also psychological; he recovered his serenity and good humor, and secured such a complete mastery over his body and mind that he won the respect of his peers. He was quick to point out, however, that his regimen was no recipe for immortality, for all things do end; his point was rather to pass away naturally, without pain and sickness.

His diet is similar to Antiochus's and Telephus's simple and digestible meals in Galen's De Sanitate tuenda: he eats bread, panado, eggs (the yolk), and soups. For meat, he has kid and mutton, poultry of any kind, and fish (p. 46). When he was about eighty years old, a slight variation in the amount of food and wine proved nearly fatal. His friends and relatives had urged him to increase his daily allowance to support his declining strength; to please them, and by way of experiment, he complied with their request, but the effect was dramatic. In a week's time, from being cheerful and energetic, he became melancholic and depressed. On the twelfth day, he had a violent pain in his side, followed by a fever that continued for thirty-five days, and looked like a man about to die. He

46 The division of life into two halves also underlies the late-medieval nomenclature for the four ages of man. In this originally Arabic scheme, widely diffused since its introduction into the Latin West in the eleventh century, the autumn of life was said to begin at either age thirty-five or forty and was called senectus, "old age."

47 N. Siraisi, The Clock and the Mirror, p. 79. 
recovered by resuming his beloved diet. Old people have less heat and consume less moisture, therefore they fast with ease, Hippocrates's Aphorisms observes $(\mathrm{I}, 13)$. As a medical commonplace put it, the flame uses oil for fuel, but if too much is added to it, it will be more quickly extinguished by it than nourished. Cornaro later reduced his diet with unprecedented austerity and discipline to as little protein as one egg per day. He did not lose his vitality — quite the opposite. As a proverb of his time put it, "What we leave after making a hearty meal does us more good than what we have eaten" (p. 24).

For Cornaro, we are literally what we eat. A sober life is so virtuous and profitable that it ought to be universal (p. 29). Rather than urging everyone to follow his example of strict abstinence, he invites the reader to find the regimen that best suits his condition. Anyone can live to age eighty and beyond by living temperately and soberly, he contends. Social and financial distinctions are of no concern to him; the treatise gives a list of healthy and inexpensive food for those who cannot afford meat (p. 46). Since, as Hippocrates and Galen observed, each individual knows more about the diet and lifestyle that suit him than anyone else, Cornaro concludes that "no man should be a perfect physician to any but himself" (p. 25). By repeated trials, deliberate reflection, and self-examination, he acquired a perfect knowledge of his constitution, and of the food and beverage that agreed with his temperament and personal habits. He discovered, for instance, that new wine suited him better than old wine, although it could be harmful to others. Regardless of individual variations, however, the quantity of food and drink allowed should invariably be small. A regular and sober life preserves our physical and mental health, cheers us up, and helps us live a long life with a sound mind. Moreover, it makes us realize that only the healthy man truly belongs to himself.

By his way of life, Cornaro had, as he put it, "shut up all other avenues of death" and knew he would only die by "mere dissolution" (p. 35). He often expresses the conviction that he would pass away with no sickness and pain, and this belief proved justified, according to contemporary sources. He drew up his will, set all his affairs in order, received the last sacrament, and quietly awaited death in his chair. His end totally fitted the laconic comment of a twentieth-century doctor on his patient's sudden death: "Went to bed healthy. Woke up dead."48

48 Quoted by Harry R. Moody, "Productive Aging and the Ideology of Old Age", in Productive Aging. Concepts and Challenges, ed. N. Morrow-Howell, J. Hinterlong, and M. Sherraden (Baltimore: Johns Hopkins, 2001), p. 179. 
Prayers to God and preparation for the soul's salvation are part of Cornaro's daily activities, yet Della vita sobria sees no incompatibility between the Christian perspective of old age as a sign of human finitude and the care of the self. "I cannot believe that the Deity desires that man, his favorite creature, should be infirm and melancholy, but rather, that he should enjoy good health and be happy," Cornaro contends (p. 63). Throughout his treatise, sobriety is almost a cult-like aim. In addition, old age has an aesthetic dimension that is very different from the Renaissance norms of proportion and ideal forms. Cornaro's treatise describes the old man's beauty in terms of ripeness. Likewise, ripe figs and olives had prompted Marcus Aurelius's meditation on time: it is when figs are "at their ripest that they burst open," the emperor noted. "In the case of very ripe olives, it is precisely their proximity to decay which adds to them a certain beauty." 49 In a similar way, rather than view the aged body in terms of decline and decay, Cornaro sees it as a stage of development in which his physical and intellectual strengths reach fruition and consolidation.

Along with Stoic sources, Cornaro's sober diet bears the imprint of an Epicurean discipline of reduction of desires. Throughout his work, the author advocates the suppression of superfluous pleasure that has negative consequences, and praises the pleasure of being, since health is the essence of life and our most precious treasure. Della vita sobria identifies three perceived plagues of the time: hypocrisy, gluttony, and Lutheranism (which allegedly corrupts the word of Christ). Cornaro focuses on gluttony, but his discussion of sobriety takes its full meaning in the broader context of all three issues since he is concerned with a moral therapy of body and mind. He contends that asceticism (in the modern sense of restriction in the use of food and drink) influences our thoughts and our will. A sober diet makes us better by raising us from an inauthentic condition of life, darkened by physical woes and harassed by passions, to an authentic state of freedom, peace, and joy. Like Petrarch, Ficino, Zerbi, or Montaigne, Cornaro could have found this notion in the Nicomachean Ethics. Aristotle's treatise was widely read in intellectual circles from the fourteenth through the sixteenth centuries. In his discussion of virtue, Aristotle argues that true happiness is a form of contemplation. "But being a man, one will also need external prosperity; for our nature is not self-sufficient for the purpose of contemplation, but our body also

49 Marcus Aurelius, The Meditations, ed. and trans. A. Farqhuarson and R. Rutherford (Oxford: Oxford University Press, 1989), 3, 2. I have slightly modified the translation. 
must be healthy and must have food and other attention" (X, 8, p. 268); 50 moreover, some virtuous acts "seem even to arise from the body" (X, 8, p. 266). In some way, Aristotle's conception of moral virtue is not that different from Galen's definition of health: both notions depend on proportion and balance. For Aristotle, moral virtue is a disposition to choose the mean between two extremes; for Galen, health is a matter of maintaining an equal amount of elementary qualities in the body. Moderation and vigilance are the master-words of Aristotle's virtuous man and of Galen's healthy individual. Interestingly, the Nicomachean Ethics associates selfindulgence and wickedness (evidence of a lack of self-mastery) with disease (VII, 8, p. 178).

For Cornaro, health was not a means to an end, but an end in itself. Foucault's characterization of the care of the self in the Hellenistic period as an aesthetic of existence has been seen as a distortion of the Greek and Roman texts he was studying; ${ }^{51}$ his view, however, corresponds well to Cornaro's perspective. In Cornaro's treatise, dietetics is the ground of all authentic interaction between the self and others. Cornaro's health regimen expresses spiritual and moral priorities; moreover, it is the predicate for any reasoned and constructive engagement with the political institution. ${ }^{52}$ For Foucault, the self-control that is at the heart of an individual's health practices makes this person able to govern others. For the patrician Cornaro, this statement would have struck a familiar note, since beginning in the 1350 s the Republic of Venice was a gerontocracy, and remained so until the eighteenth century. Between 1400 and 1600 , the average age of the doges elected from the Procurators of San Marco was seventy-two. ${ }^{53}$ There was no fixed retirement age for many elite positions, and appointments could be made at advanced ages. Only a healthy individual can keep up regularly with the affairs of state and public matters; those who make crucial political decisions cannot afford to take repeated sick leaves; they must either put off such affairs until a

50 Aristotle, The Nicomachean Ethics, ed. and trans. D. Ross (Oxford: University Press, 1980). See also Aristotle's following remark: "In everything that is continuous and divisible it is possible to take more, less, or an equal amount, and that either in terms of the thing itself or relatively to us; and the equal is an intermediate between excess and defect" (II, 6, p. 37). All further references are to this edition and are incorporated into the text.

51 See Wolfgang Detel, Foucault and Classical Antiquity. Power, Ethics and Knowledge, trans. D. Wigg-Wolf (Cambridge: Cambridge University Press, 2005), pp. 93-117.

52 Foucault, L'Herméneutique du sujet, pp. 241-42.

53 Robert Finlay, "The Venetian Republic as a Gerontocracy: Age and Politics in the Renaissance", Journal of Medieval and Renaissance Studies 8, 2 (1978), p. 157. 
later time, or delegate their responsibilities to others. Both avenues are prejudicial to their fellow citizens, and to the state. Such was precisely the problem in Cornaro's Venice. A law granted the patricians aged seventy and older permission to leave the Senate before the end of extremely long debates. A contemporary observer noted that many decrepit Venetians were unable to fulfill their political duties; other accounts blame the senility of Doge Antonio Grimani, who refused to abdicate at age ninety. Antonio Tron was elected to the Collegio in January 1524, but declined, stating that his joints were frozen. He passed away a week later, at age ninety-four. ${ }^{54}$ No wonder then, that Cornaro praises the healthy longevity of Venetians Pietro Lando and Pietro Bembo. Lando was a doge from 1538 to 1548, and became Podestà of Padua at age seventy-three; Cardinal Bembo died at age seventy-seven. To these names, Cornaro proudly added his own one. His treatise reported that he continued his work of draining and improving uncultivated pieces of Venice's ground well into his nineties - a respectable age even by his fellow patricians' standards.

Della Vita sobria was the pragmatic solution to the darkest sides of senescence. The author's contention that old age is a highly desirable stage of life instead of a period fraught with difficulties was part of his campaign for-or marketing of-longevity. For Cornaro, since we control our bodies and minds, health should be our major goal; every individual is responsible for caring for himself in an appropriate way. This simple and universal statement was the foundation of his art of aging gracefully and virtuously, and came with full proof of its efficiency, in the form of a personal narrative. Cornaro's everyday life was, indeed, his masterpiece.

Yet as Erasmus and Montaigne respectively point out, to what extent does any portrait of the "forever young old man" suggest that a person has managed to put on a happy face for the rest of the world? Old men like Cornaro may well project an image of vigor, happiness, and intellectual well-being; but in reality their bones are surely aching, and their mind has lost its acuity.

\section{Erasmus}

Anachronism is often seen as an inability to think in historical terms, or as a type of scholarly error. For the historian, it is a preposterous failure

54 See Robert Finlay, "The Venetian Republic as a Gerontocracy", pp. 157-78. 
to understand the past. Yet preposterous thinking can be a creative way of reading a text in anticipation of another. About fifty years before Della vita sobria, Erasmus's Praise of Folly (1511) had already turned upside down the philosophical foundations of Cornaro's views on aging successfully. ${ }^{55}$ Of course, this was not a matter of prescience, but of reference to the same classical tradition. Whereas the Galenic tradition discussed aging in relation to the appearance and the functioning of the body, Erasmus's monologue praises the loss of control of the self that is associated with dementia. In this sense, senility represents the ultimate failure of what Norbert Elias terms the "civilized body." The behaviors most associated with the care of the self (looking after oneself, controling bodily functions and modulating the expression of emotions, all behaviors which Elias described as central to the civilizing process) become eroded. A body the mind has lost control of becomes a de-civilized body. ${ }^{56}$ In this respect, dementia is the public failure of an individual's claim to self-mastery and self-control.

For Erasmus's Folly, old men are natural fools, and therefore are among the happiest of men, since senile dementia provides them with the means to render life enjoyable: "Clearly, no mortal could tolerate the pains of age if I did not take pity on them and offer my help," she claims (p. 20). In Cicero's De Senectute, old age is the crowning of Cato the Elder's existence; it opens up a whole way of being that frees him from his youth's imperfections, and brings him serenity, wisdom, and experience. ${ }^{57}$ Erasmus turns Cicero's apology upside down to praise the elder's loss of physical and cognitive capacities. In an extraordinary tour de force, Folly presents senility as the embodiment of Epicurean, Stoic, and Skeptic ideals. She argues that senility is the perfect state of Stoic and Epicurean ataraxia and apatheia because the man who suffers from dementia has no passions and no emotions; he is indifferent to opinions and events. He has no changes of mood and is unaffected by the physical discomforts of old age because he is not even aware of them. Senility means neither depression, nor boredom (contrary to the humoral theory's views on decrepitude), but rather peace of mind since it brings disengagement. Like the Epicurean

55 Erasmus, The Praise of Folly, ed. and trans. C. H. Miller (New Haven: Yale University Press, 1979). All further references are to this edition and are incorporated into the text. For the Latin text, see Moriae Encomium (Basel: Froben, 1540). http://openlibrary.org/books/OL24970664M/ Moriae_encomium_id_est_Stulticiae_laudatio_ludicra_declamatione_tractata.

56 Norbert Elias, The History of Manners. The Civilizing Process, vol. 1, trans. E. Jephcott (New York: Urizen, 1978).

57 See chapter 2 on Cicero's De Senectute. 
moralist, the senile man has no superfluous needs and no aspirations, but focuses instead on the essential pleasures of life: the satisfaction of his body's basic functions-eating, drinking, and sleeping. Like the perfect Stoic or Epicurean philosopher, he has no worries about the future, and no regrets about the past, for he has no memory. He lives in the present moment, since his mind has lost its grip on reality. Consequently, he has no reason to prepare for death and the afterlife because he cannot conceptualize them. His freedom from care is admirable and unassailable. An accomplished Stoic and Epicurean philosopher, he is also an exemplary Pyrrhonian skeptic: everything is literally indifferent to him since he is unable to differentiate one thing from another.

Vigilance, self-control, and discipline are the master-words of Stoicism and the foundation of Cicero's apology of old age in De Senectute. These notions are also at the heart of health regimens, especially those for the elders whose frail condition requires more attention. Yet in Erasmus's mock encomium, the elder's inaptitude of caring for himself secures his wellbeing. Drawing from Plato's Republic and Cicero's De Senectute, authors such as Cornaro, Ficino, and Zerbi stress the civic purpose of a healthy longevity. In contrast, Folly praises the elder's uselessness. Throughout her discourse, old age's losses become its most valuable assets. Wasting time rather than saving it is an old man's healthiest habit, according to Folly. Rather than training and stimulating his mind as doctors and philosophers urge the senior to do, Folly contends that he should let his intellectual strengths fade, in order to maintain his serenity. Furthermore, senile dementia makes an old man the merriest companion of all. Cato the Elder in Cicero's De Senectute, along with Petrarch and Cornaro, felt that they had a better knowledge of themselves and more serenity in their later years; they were convinced that they also had a better understanding of their lives as a whole. In Erasmus's paradoxical praise, by contrast, the lack of direction of the senile man's life is the very sign of wisdom.

Folly's paradoxes take their full meaning in a time when problems related to old age were gaining momentum. The growing number of editions and translations of Cicero's De Senectute, and the rise in written health advice and regimens for the elderly were among the many signs of this concern. Longevity was definitely on the agenda of Folly's targeted audience, yet the strength of Erasmus's masterpiece was not only the timeliness of the issues addressed, but also their perennial truth. The author's long interest in commonplaces is especially relevant; his Praise of Folly is full of proverbs that broaden the scope of the protagonist's views while contributing to the creation of an oral and familiar style. Time 
destroys everything except human folly. Folly describes general aspects of old age, irrespective of social function or financial situation. Human life's comedy is entertaining as long as one can keep its basic illusions; to strip them away is to despair or to commit suicide. The reader is poised between seemingly contradictory reactions: with a laugh, a smile, and a rueful sigh, he has to admit that there is truth in Folly's irony. She reminds us of the provisional and fragmentary nature of any perspective on the human life cycle, and stresses that multiple interpretations can be woven around the same basic set of facts. Folly's strength is in her understanding of human beings' contradictions, in her tolerance of their paradoxes and ambiguities, in her awareness of the inconsistency of abstract and theoretical systems of knowledge in the light of human experience. She forces us to take an affectionate distance from ourselves, and urges us not to be taken in by the various characters we play, since none of them totally represents us. Montaigne's comments on old age elaborate on similar games of self-reflection, as we shall see.

When it comes to the alleged wisdom of old age, Folly's judgment is straightforward:

Who would want any contact or association with an old man who added to his wealth of experience a corresponding vigor of mind and sharpness of judgment? And so through my favor, an old man loses contact with reality. But at the same time he is relieved of all those wretched worries that torment the wise man. (p. 21)

She finds the stereotyped oppositions between young and old to be irrelevant since the human life cycle is fundamentally circular. Building on the widespread notion of old age as a "second childhood" (an expression by Lucian quoted in Erasmus's Adagia 436), Folly stresses the similarities between babies and old men: "whitish hair, toothless gums, a small bodily frame, and a liking for milk; both stutter and babble and engage in tomfoolery; both are forgetful and thoughtless" (p. 22). From her paradoxical perspective, old age along with its failing senses, fading strength, and dementia, is the absolute fountain of youth.

Yet this is not Folly's last word. She is Youth's daughter, and as such she worships the sculptural beauty of the young virile athlete. Playfully contradicting herself, she is quick to turn her own statements upside down. She now finds the "toothless, white-haired, bald" old man "filthy, crook-backed wretched, shriveled;" and reminds us that it is impossible to negate the effects of time on the human body and mind, as Cicero's De Senectute and Cornaro's Della Vita sobria did. She even contends that elders are "men 
who no longer even look like men" (p. 48), and cruelly mocks their obstinacy in clinging to life. "The less cause they have to remain in this life, they more they want to stay alive," she says (p. 48).

Folly's remarks are part of Erasmus's broader meditation on man's folly in the eyes of God. In addition, the question of aging was close to the humanist's heart. He wrote his Praise of Folly when he was on his way to England, suffering from a kidney ailment, and considered himself old well before the publication of this best-selling book. From his thirties on, his frail health and his age were a matter of concern in numerous letters, including one to Servatius Rogerus, the prior of the monastery of Steyn on April 1, 1506.58 This question is also at the center of Carmen Alpestre, Erasmus's most famous poem. ${ }^{59}$ The text (also called Carmen De Senectute), dated August 1506, was written when the humanist-then in his thirties-was crossing the Alps on his way to Turin to receive a doctorate in theology. ${ }^{60}$ The poem is dedicated to Erasmus's physician, the famous Guillaume Cop of Basel. Despite his erudition and skills, Cop is unable to cure the worst of all evils: old age. It ravages Erasmus's mind and body to such an extent that he does not recognize himself. In the poem, he describes his symptoms by referring to a standard literary and medical catalog of the woes of old age, and concludes that it is none other than a slow death. He finds himself thinking nostalgically of the vigor of his earlier years, but nothing can bring youth back, certainly not occult and magical practices. He realizes too late that he has wasted his life in futile undertakings, and that his existence was a kind of death in life. He concludes that since he is only at the onset of old age, he still has time to change his way of life.

The poem gives an allegorical interpretation of Aristotle's view of old age as a disease, and points out human finitude and the preciousness of time. The point of the conversion is to give up "useless" knowledge. The goal is not to disengage one from external reality but to change one's manner of knowing things. Erasmus bids farewell to the vain pleasures of his youth, and realizes that his existence has no meaning except through

58 Erasmus, Opus Epistolarum Desiderii Erasmi, ed. P. S. Allen (Oxford: Clarendon Press, 1906-58), vol. 1, pp. 420-21. English translation in Collected Works of Erasmus, vol. 2, The Correspondence of Erasmus 1501-1514, trans. R. A. B. Mynors and D. F. S. Thomson (Toronto: University of Toronto Press, 1974), pp. 110-11.

59 Further references are to the bilingual edition of the poem in Erasmus, Collected Works of Erasmus, trans. C. H. Miller, ed. H. Vredeveld (Toronto: University of Toronto Press, 1993), vol. 85, pp. 13-25.

60 Erasmus's birth date is unknown. Scholars often suggest 1476. He died in 1536 . 
Christ. From now on, he will seek to purify and rectify his intentions at every instant; he will also be on the lookout for signs within himself of any motive for action other than the will of God. His conversion associates old age with a time of self-reflection, virtue, faith, and the preparation of the afterlife. Such will be the exclusive focus of this new phase of the protagonist's existence.

As a pedagogical story, Carmen Alpestre aims to facilitate a reading through identification with the author's persona. The poem's biographical fiction (partly inspired by classical literary and philosophical references) teaches the reader to consider God as the guiding principle of his life and represents the infirmities of old age as the effects of sin and the embodiment of human finitude. Echoing Erasmus's Enchiridion militis Christiani, Carmen Alpestre advocates vigilance and self-control. Attention to the present situates man in his genuine being, which is in relation to God. For Cornaro, health is the focus of daily life; for writers such as Erasmus and Petrarch, on the other hand, health transcends daily practices, and is a gift from God. The person who pursues virtue and devotes his life to God has the power to separate his soul from the woes and the needs of his body.

\section{Montaigne}

Although Erasmus had no particular expertise in medicine, it is no surprise that he edited three Galenic treatises in Latin in $15^{26}$. The works of Galen and his followers were part of the humanist culture. Medical humanism (a major Renaissance innovation) reflected a broader philological concern for classical texts. Galen himself was a model of such scholarship, having written commentaries on texts attributed to Hippocrates. The Renaissance proliferation of editions and translations brought greater attention to ancient Greek medical works, especially to Galen's treatises. In Venice, the librarian and printer Aldus Manutius published the first edition of Galen's complete works in 1525. In France, Galen's treatise On Hygiene (De Sanitate tuenda) was published eight times in Paris and Lyon between 1525 and 1559; five of these editions were Thomas Linacre's Latin version. ${ }^{61}$ In addition, Canappe translated Galen's complete works into French. Hippocratic treatises enjoyed a similar reputation. Aldus Manutius published Hippocrates's complete works in $\mathbf{1 5 2 6}$. His Aphorisms were particularly

${ }^{61}$ Richard J. Durling, "A Chronological Census of Renaissance Editions and Translations of Galen," Journal of the Warburg and Courtauld Institutes 24, 3-4 (1961), pp. 239-305. 
popular because of their concise and accessible formulation; they had fifteen editions in Lyon and Paris during Montaigne's time, and were translated into French by Jean Bresche. ${ }^{62}$

Petrarch, Cornaro, and Erasmus see old age as a transformative stage of life. Montaigne, on the other hand, is obsessed with the process of aging. This ongoing experience is constitutive of who he is at every point in the Essais: a being rooted in history, yet open to his own future as part of a narrative whose further unfolding will only be interrupted by death. Referring to the Aristotelian view of old age as a disease, he notes at the end of the chapter "Of Repentance":

Quelles Metamorphoses lui voy-je faire tous les jours en plusieurs de mes cognoissans! C'est une puissante maladie, et qui se coule naturellement et imperceptiblement. Il y faut grande provision d'estude et grande precaution pour eviter les imperfections qu'elle nous charge, ou aumoins affoiblir leur progrets. Je sens que, nonobstant tous mes retranchemens, elle gaigne pied à pied sur moy. Je soustien tant que je puis. Mais je ne sçay en fin où elle me menera moy-mesme. A toutes avantures, je suis content qu'on sçache d'où je seray tombé. (III, 2, p. 817) ) $^{63}$

What metamorphoses I see old age producing every day in many of my acquaintances! It is a powerful malady, and it creeps up on us naturally and imperceptibly. We need a great provision of study, and great precaution, to avoid the imperfections it loads upon us, or at least to slow up their progress. I feel that, notwithstanding all my retrenchments, it gains on me foot by foot. I stand fast as well as I can. But I do not know where it will lead even me in the end. In any event, I am glad to have people know whence I shall have fallen. (p. 753)

As the word "metamorphoses" suggests, aging opens up diverse and sometimes contradictory meanings tied to persistent, malleable features of the construction of Montaigne's authorial identity over the years. His comments go back and forth between positive and negative views of aging. As the years go by, his mood varies between the "jovial and the melancholy" ("entre le jovial et le melancholique," II, 17, p. 641/p. 590) as a 1588 addition to the chapter "Of Presumption" puts it, and often superimposes both states of mind. Each of Montaigne's comments takes its full meaning when situated in its specific context. Yet whether he sees old age as a dis-

62 Ibid., pp. 239-305.

63 Page numbers for Montaigne's Essais refer first to the standard edition, edited by Pierre Villey and Verdun-L. Saulnier (Paris: PUF, 2004), and then to Donald Frame's translation The Complete Works of Montaigne (New York: Knopf, 2003). 
ease, as in "Of Repentance" (III, 2, p. 817/p. 753), or as a natural process, does not make much difference: in either case, he stresses the irreversible effects of time on human beings, and never asks for an extension of life. He even praises the seventy-year-old Socrates, who to some extent invited his death sentence, thereby avoiding the dimming of his mind's "accustomed brightness"(“clairté accoustumée," III, 2, p. 817/p. 753). In the same way, the chapter "Of Experience" pokes fun at old men who foolishly dream of preserving their youthful vigor:

Voyez un vieillart, qui demande à Dieu qu'il luy maintienne sa santé entiere et vigoreuse, c'est à dire qu'il le remette en jeunesse.... N'est-ce pas folie? Sa condition ne le porte pas.... Mon bon homme, c'est faict: on ne vous sçauroit redresser; on vous plastrera pour le plus et estançonnera un peu, et allongera on de quelques heures vostre misere. (III, 13, p. 1089)

Look at an old man praying God to keep him in entire and vigorous health, that is to say, to restore his youth.... Is it not madness? His condition does not allow it.... My good man, it is all over. No one can put you on your feet again; at most they will plaster and prop you up a bit, and prolong your misery an hour or so. (p. 1017)

He was nevertheless concerned about finding ways to adjust to such negative effects and compensate for the losses. The chapter "Of Experience" (Essais, III, 13) provides a fruitful way to examine his confrontation with his aging and ailing body. Throughout these pages, the essayist's ironic lucidity signals his will to cope with an irreversible biological phenomenon, while attempting to slow it down. Rejecting passive resignation, he tries out various strategies to adjust to the effects of time, and offers the humorous story of his imaginative-yet somehow inconclusive-attempts to compensate for his losses, and even capitalize on them.

I do not suggest that there is an overarching architecture in Montaigne's Essais, yet it is impossible not to notice the connections between the Latin quotations placed at the end of books I and III. The last paragraphs of the chapter "Of Age" (I, 57) quote Lucretius's vivid image of the destructive effects of time on the human body and mind:

Ubi jam validis, quassatum est viribus aevi

Corpus, et obtusis ceciderunt viribus artus,

Claudicat ingenium, delirat linguaque mensque. (I, 57, p. 328)

When age has crushed the body with its might,

The limbs collapse with weakness and decay,

The judgment limps, and mind and speech give way. (p. 289) 
Compared to Lucretius's representation of decay at the end of book I, the Latin prayer that appears in the final words of book III strikes a more hopeful tone. Borrowing the words of an ode by Horace, Montaigne begs Apollo, the god of medicine and poetry, to allow him to keep a sound mind in a healthy body in old age, along with his creative energy:

Frui paratis et valido mihi,

Latoe, dones, et, precor, integra

Cum mente, nec turpem senectam

Degere, nec cythara carentem. ("Of Experience" III, 13, p. 1116)

Grant me but health, Latona's son,

And to enjoy the wealth I've won,

And honored age, with mind entire

And not unsolaced by the lyre. (p. 1045)

Only death could put an end to Montaigne's literary endeavor, yet these last words remained untouched. Without waiting for Apollo's eventual intervention on his behalf, he had actually taken care of his wishes as best as he could. The first step in this direction was self-observation.

At first glance, self-observation seems a highly intimate and personal activity, but as Foucault notes, this notion has its own historicity and is embedded in the systems of knowledge (medical, philosophical, cultural, and social, etc.) of the day. Montaigne's comment on his health regimen in the chapter "Of Experience" makes perfect sense in this respect since regimens are ways of looking at the human subject at grips with experience. When the essayist wages war on medical dogmatism in this chapter, he does not challenge medicine's practical aspects. Eclectic and idiosyncratic as his remarks on his health care are, they comply with the basic tenets of the Hippocratic-Galenic humoral physiology of the day. Montaigne seemed to have used a broad range of sources. Health regimens and diet books had an obvious interest for him. First, their practical goals and accessible presentation stood in sharp contrast to the hermetic and pretentious jargon used by those medical authorities whom Montaigne criticized as ignorant and incompetent. Second, health regimens were part of the development of empirical sciences, and Montaigne's interest in this field is obvious. Third, they included a wide variety of remarks-personal anecdotes, clinical observations, proverbs, borrowings, or quotations from the Ancients, and so on. The diversity of their references and their flexible organization had many similarities with the informal genre of the essay. In addition, from Galen on, some health regimens contained personal accounts and were written in the first person. Contemporary books 
such as Girolamo Cardano's De Sanitate tuenda (1570) and Cornaro's bestselling treatise Della Vita Sobria (translated into several languages including French) exemplify this trend.

Whether Montaigne was familiar with the works of Cornaro and Cardano is a matter of speculation, but he had certainly read Laurent Joubert's widely circulating two books of Erreurs populaires au fait de la médecine et régime de santé (1578-1579). Joubert, the Chancellor of the University of Montpellier, had the same publishers as Montaigne: Millanges and L'Angelier. In the second chapter of The First Part of the Popular Errors, Joubert wonders if it is possible for medicine to prolong human life, and notes that such speculation has always been intense and has excited the greatest minds. He concludes that it is possible to elongate the terms of all ages, and thus of all life, by medicine, even further than is ordered by Nature, but does not suggest a method for achieving this goal. ${ }^{64}$

Montaigne's comments on his health offer a reflection on contemporary advice from the perspective of a particularly acute observer. What matters is not what a health regimen does for Montaigne, but how a set of self-regulated practices participates in the representation of a self who carefully watches the effects of aging on his body and mind. Despite the essayist's skepticism and independence, he remains faithful to the foundations of humoral physiology. As Jean Starobinski noted, the description of Montaigne's care of himself in the chapter "Of Experience" follows the standard "catalog" of the six non-naturals (air, food and drink, motion and rest, sleep and wakefulness, retentions and excretions, emotions and passions). ${ }^{65}$ Building on Starobinski's findings, I examine these six aspects in relation to the essayist's emphasis on his age in "Of Experience." In this chapter Montaigne reports his age (fifty-six), and takes a lucid look at the signs of his physical decline. These include the loss of a tooth, a blurring of vision at night, an increasingly melancholic mood, and a greater sensitivity to cold. Montaigne first attends to air quality, and "fear[s] a stuffy atmosphere," as well as smoke and the heat of the summer (first non-natural, pp. 1104-5/p. 1033). Given his age, he notes a decrease in his body's inner heat. He then describes his clothes, a detail that often appears in health regimens (in Zerbi's Gerontocomia, for instance, or, closer to Montaigne, in Laurent Joubert's outline of his regimen in the

64 Laurent Joubert, The First Part of the Popular Errors, ed. and trans. Gregory de Rocher (Tuscaloosa: University of Alabama Press, 1989), pp. 38-43.

65 Starobinski, Montaigne en mouvement, p. 87. 
projected Third Part of the Popular Errors). ${ }^{66}$ The essayist also notices an increase in his hours of sleep (pp. 1095-96/p. 1024), a typical feature of old age according to contemporary physicians. His moderate physical exercises include walking (p. 1096/p. 1024), an activity that Galen already found particularly apt to elders (third non-natural). Moreover, following the general prohibition of sexual activities that weaken the old man's frail condition, he sleeps alone. Excretion, along with sex, is part of the fifth non-natural, and Montaigne subsequently reports that he does not suffer from constipation, a frequent problem of old age, according to Galen's $D e$ Sanitate tuenda. Finally, the essayist is aware of the destructive effects of passions and emotions (sixth non-natural), and had retired from the Parliament of Bordeaux at age thirty-eight, when he considered himself old. He values his freedom from care, and is convinced that excessive professional worries hastened his father's death.

As in most contemporary health regimens, diet is central in the essayist's account of his daily care (second non-natural). His eating and drinking habits depend partly on economic constraints (the circulation of foodstuffs in his geographical area) and social conditions (the lifestyle of an aristocrat, the particularities of his specific milieu, etc.). ${ }^{67}$ But regardless of these questions, Montaigne largely follows the Galenic prescriptions for the elderly. In contrast to the lavish banquets of his wealthy contemporaries, his meals are sober. He does not fast, but occasionally skips a meal to whet his appetite. "Of Experience" emphasizes the essayist's anti-court culinary tastes. His impatience with endless meals, his increasing moderation in sauces, and his lack of taste for spices and for sweets contradict the fashionable menus of the French aristocracy and coincide with the recommendations of diet books such as those of Cornaro or Cardano. He eats only one substantial meal a day (p. 1084/p. 1012), and his diet is not very different from that of Antiochus and Telephus in Galen's De Sanitate tuenda. His food is easy to digest, and includes fish and bread (p. 1103/p. 1031), since age has weakened his stomach. He drinks wine mixed with water (p. 1104/p. 1033) for it quenches thirst better, is more refreshing, and moistens the body more thoroughly than water alone, as Laurent Joubert's Second Part of the Popular Errors observed. Following Galen's De Sanitate

66 Laurent Joubert, The Second Part of the Popular Errors, ed. and trans. G. de Rocher (Tuscaloosa: University of Alabama Press, 1995), p. XII.

67 Classes were increasingly differentiated by their specific styles of eating. Montaigne rejects snails, which are suitable only for one of his servants. He also thereby follows Galen's warning that snails' thick juice was dangerous for the elderly. 
tuenda, Joubert noted that wine was both food and drink, and worked like medicine by warming and moistening, cheering up, restoring the blood, and aiding sleep and digestion (p. 29).

Since body and mind are connected, faulty digestion or inappropriate food cloud the thoughts and the intellect. Nevertheless, Montaigne prefers medium-cooked meat, although it is less digestible than stewed meat, and thus not advisable for the elderly. A diet based on preferences is, of course, highly appropriate to a chapter focusing on personal experience and observation. Moreover, for authors such as Joubert, Cornaro, and Cardano, a regimen should take into account individual habits, since frequent use creates a "second nature," as Hippocrates and Galen had noted. Montaigne was clearly attacking contemporary physicians who had reduced Galenism to a set of rigid principles, with no latitude for personal habits and individual experience. ${ }^{68}$ His contemporary, Jacques Du Laurens, Joubert's successor as Chancellor of the University of Montpellier, epitomized this tendency; he was a famous anatomist who later became Henri IV's doctor. Du Laurens's Discours de la conservation de la veue des maladies melancholiques des catarrhes et de la vieillesse appeared in 1594, two years after Montaigne's death, but his views were known in the essayist's intellectual circle. Du Laurens's fourth discourse is the first French health treatise for the elderly. His Quatrième discours auquel est traicté de la vieillesse et comme il la faut entretenir (et non guérir) closely follows Galen, but speaks of the elderly as a homogeneous group with the same characteristics and the same reactions. For Du Laurens, everyone should follow the same practices when it comes to the conservation of health in old age. ${ }^{69}$

As expected, Montaigne's dietary practices in "Of Experience" strike a much more personal note. He openly transgresses some basic Galenic advice: he expresses guilt over eating too greedily, although he knows the importance of eating slowly and chewing for digesting (p. 1105/p. 1032).

68 See Montaigne's remark: “Tibere disoit que quiconque avoit vescu vingt ans se debvoit respondre des choses qui lui estoyent nuisibles ou salutaires, et se sçavoir conduire sans medecine" (III, 13, p. 1079).

69 André Du Laurens, (1558-1609). Discours de la conservation de la veue: des maladies melancholiques, des catarrhes et de la vieillesse, Paris: Mettayer, 1597. The book was written at the Duchesse d'Uzès's request, but addresses a male audience. Most of the advice, however, is relevant for male and female patients. The duchess, who was in her fifties, suffered from all four problems mentioned in the title of Du Laurens's treatise. From his first edition in 1594 to 1630 , the treatise was published about ten times; in addition, it was translated into Italian and English. 
According to Galen, the senior (whose body is cold and dry) should eat well-prepared, easily-digested foods that warm the body and maintain its moisture (eggs, oil, milk, certain meat), and avoid fruit and most vegetables. Montaigne, for his part, indulges in food that is difficult to digest, and acknowledges his taste for melons, believed to rot in the intestine (p. 1102/p. 1031).

The notes taken during his voyage to Italy when he was forty-seven give further information on his dietary habits. ${ }^{70} \mathrm{He}$ treats his guests with poultry and veal, well suited to stomachs weakened by age. Like Cornaro, he follows Galen's advice to eat bread in old age. The simplicity of Montaigne's meals is striking; the only lavish meal he enthusiastically describes takes place in Lindau, Germany, and includes a variety of soups, fish, and venison, with fruits and spices (p. 1146/p. 1086). During his travels he enjoys regional foods and wines, and laments that he did not take his cook along to note down the recipes. Throughout the Voyage en Italie, temperance is the moderator, not the adversary, of pleasure. Health and pleasure reinforce each other; Montaigne's diet meets his body's daily requirements without austerity. He limits himself to one substantial meal a day, but the older he grows the more he enjoys the taste of food and wine.

In Montaigne's "Of Experience," the Galenic principles for conserving health in old age are compatible with voluptas, and are part of the celebration of a broader ideal of moderation. Interestingly, the essayist's praise of the juste milieu immediately follows his comments on his daily health care. For Montaigne, health and life are a matter of balance, and he brings moral philosophy down "on the table," noting that "the consciousness of having spent the other hours well is a proper and savory sauce for the dinner table" ("la conscience d'avoir bien dispensé les autres heures est un juste et savoureux condimant des tables," pp. 1108-9/p. 1037).

Finally, the aged Montaigne's concern for his health is also obvious in his ideal of retreat. Critics usually comment on his lifestyle in philosophical terms, but this perspective does not exclude a medical one-quite the opposite in fact. From Antiquity on, medicine and philosophy intertwine. Montaigne's favorite activities as described in the chapter "De trois commerces" (III, 10) echo Stoic sources, but do not differ much from Galenic advice to the elderly: the essayist avoids the tensions of the city, and lives

70 Montaigne, Voyage en Italie, in Montaigne, CEuvres complètes, ed. A. Thibaudet and M. Rat (Paris: Gallimard, 1962). English translations refer to Frame's edition of Montaigne's Complete Works. References to both works are incorporated into the text. The first page number refers to the French edition, the second one to the English translation. 
in his castle surrounded by a circle of close friends and books. Along with intellectual exchanges, he enjoys the company of women whose beauty is a feast for the eyes. Physicians such as Marsilio Ficino, whose work Montaigne had read, stressed the importance of sensual pleasures for combating learned men's propensity to senile melancholy. Joy, hope, and good mood have a long philosophical history, but one is prone to forget that from the Ancients on, doctors have stressed the therapeutic effects of a positive state of mind. Montaigne could have read a confirmation of this theory in Laurent Joubert's Treatise on Laughter. ${ }^{71}$ These effects were especially important in the case of elderly men prone to melancholy; consequently, Zerbi and Ficino had put old age under the sign of the planet Saturn. Among the great blessings in this respect are health and good humor, which are interdependent.

The long prosopopoeia ${ }^{72}$ that appears in "Of Experience" gives a suggestive example of Montaigne's ironic and humorous representation of his aging self. Commentators have studied the rhetorical aspect of this discourse, but have largely put aside Montaigne's meditation on the effects of time on his body and mind. Yet the essayist's kidney ailment- the most painful symptom of his physical decline-is the pretext for this fictitious address to the self. In some ways, Montaigne describes a condition similar to Erasmus in Carmen Alpestre ${ }^{73}$ for both writers old age appears as an incurable and powerful process of decline ("Of Repentance," III, 2, p. $817 /$ p. 753). In contrast to Erasmus, however, Montaigne does not interpret the woes of old age in a religious perspective; he does not pursue the notion that bodily afflictions bring man closer to God, but acknowledges human finitude with a smile.

The prosopopoeia is a montage of literary, biblical, and philosophical references that focus on the relationship between Montaigne's body and mind. In an attempt to overcome his physical sufferings and his melancholic mood, Montaigne imagines that his own mind comforts him and persuades him to accept his limitations. The "mind" reminds the essayist that his kidney ailment appeared late in his life and that aging is part of life. To live means aging and dying; it is because Montaigne is alive that

71 Laurent Joubert, Treatise on Laughter, ed. and trans. Gregory de Rocher (Tuscaloosa: University of Alabama Press, 1980).

72 I use Quintilian's spelling in his Institutio oratoria. The Orator's Education, ed. and trans. D. A. Russell, Loeb Classical Library (Cambridge, Mass.: Harvard University Press, 2001).

73 See above. 
his health is a matter of concern to him. His kidney stones may be painful, but they have nevertheless some advantages since he has received many compliments for his courage. The "mind" also finds it reassuring that Montaigne already knows the cause of his death; his ailment helps him to get used to the idea of death. Moreover, he has no reason to wish to live longer because an extension would mean more days of physical suffering. On the brighter side, the "mind" observes that Montaigne is fortunate to have an active social life and a sound mind. By the end of this long discourse of consolation, Montaigne's efforts to overcome his senile melancholy and his physical sufferings become the object of an ironic and lucid comment:

Par tels argumens, et forts et foibles, comme Cicero le mal de sa vieillesse, j'essaye d'endormir et amuser mon imagination, et gresser ses playes. Si elles s'empirent demain, demain nous y pourvoyerons d'autres eschapatoires. (III, 13, p. 1095)

By such arguments, both strong and weak, I try to lull and beguile my imagination and salve its wounds, as Cicero did his disease of old age. If they get worse tomorrow, tomorrow we shall provide other ways of escape. (p. 1023)

Montaigne's comment stresses the alternation of pain and joy, their inextricable blending, their mutual conditioning. The essayist describes a condition of age in which, in contrast to the aged and sick body, the mind continues to be flexible in its own manner and in pursuit of its own aims. One of the fundamental paradoxes of this discourse is that the rational subject (epitomized by "the mind") in Montaigne wants to control his experience of growing old but remains, nevertheless, part of it, and consequently gets caught in his own actions. As his last comment makes clear, he confronts the woes of old age not through abstract planning and reasoning, but with a smile. Montaigne was rereading Cicero's De Senectute at the time he was writing the last chapters of the Essais's book III. Sometimes his "mind" puts forward arguments borrowed from Cicero's apology of old age, but any praise of old age proves to be a masquerade.

One might be tempted to stop here, but Montaigne goes further, noting that the consoling discourse uttered by his "mind" is ultimately a tactical maneuver. Instead of giving in to Cicero's platitudes and negating the woes of old age, the essayist understands that an honest look at his pains is the precondition to coping with the physical weaknesses of his later years. His final remark signals his affectionate distancing from himself; he is not taken in by a performance in which he is simultaneously 
the observer, the participant, and the stage director. Rather than think of Montaigne's "self" as an entity, the prosopopoeia invites us to think of it as the "kind of awareness in process" that Paul John Eakin sees as a central aspect of autobiographical narratives: "there is always a gap or rupture that divides us from the knowledge we seek,"

We do better, I think, to speak of "registers of self and self-experiences", for there are many stories of self to tell, and more than one self to tell them. ${ }^{74}$

Although the arguments put forward by Montaigne's "mind" should not be accepted at face value, in the end this fictitious discourse of consolation proves to be an entertaining way to pass the time: it was a way to divert the gloom of old age for a while. Such reaction conveys a feeling of acceptance of physical decline over time, rather than resignation to it; it draws strength and courage from a lived experience, however daunting. Montaigne complains elsewhere of the decline of his aging mind; ${ }^{75}$ this is certainly not the case of his imagination which he "treat[s] as gently as [he] can" ("je trete mon imagination le plus doucement que je puis," III, 13, pp. 109o/1018). ${ }^{76}$ The prosopopoeia is part of a series of modest and ongoing proposals to divert temporarily the gloom of old age. In the end, Montaigne realizes that what matters is the effort not the result. The chapter "On some verses of Virgil" (III, 5) will give us another way to examine this strategy later on. ${ }^{77}$

In the prosopopoeia Montaigne challenges Plato's contention in Phaedo that the body should not rule over the mind. He does not simply invert this power relation but acknowledges the impossibility of dissociating the body from the mind. This process of narration leads Montaigne toward this insight, and opens up the possibility of intercommunion among distinct "selves" with alternative perspectives. The "mind" is a mask, and the writer's comment on his fictitious address to himself is another mask that creates an "inner space" from which Montaigne is able to present a stable identity. This representation does not alter the function or condition of identity itself, but rather dissolves facades of wholeness and stability. Aging emerges as a process of increasing multiple identities, and dialogue with one's self. Paradoxically, this process engenders a rounded

74 John Paul Eakin, Our Lives Become Stories. Making Selves (Ithaca: Cornell University Press, 1999), pp. $\mathrm{x}-\mathrm{xi}$. On this issue, see also chapter 4 , section 3 of this study.

75 "l'esprit se constipe et croupit en vieillissant" (III, 2, p. 815/p. 752).

76 On this issue, see also chapter 4 , section 3 of this study.

77 See chapter 3 , the section on Montaigne, and chapter 4 , section 3 of this study. 
sense of self, along with an understanding of the contradictions within the human being. As anthropologist Sharon Kaufman observes, within each aging person's life narrative there is an "ageless self." 78 For Montaigne, the conflict that arises among these competing stories of selves tells him that accounts of old age are often artificial stories-poses and performances. As a good actor, Montaigne is able to perform the standard repertoire of characters epitomizing the wise and exemplary old man: stoic courage, heroism, patience, and resignation all have a role in consoling the mind. Yet the essayist's last comment relates these attitudes to distorted representations of what old age really means to him. He humorously demystifies the ready-made scenarios offered by his mind, and which readers expected to find in his self-portrait. In an ironic and vertiginous game of self-reflections reminiscent of Erasmus's Praise of Folly, he shows himself being aware of his being aware of himself.

\section{Conclusion}

In the introduction of The Use of Pleasure, Foucault outlines his thesis: to identify the historical forms taken by the self as a subject of desire, to analyze the practices through which this "problematization" was effected, and to examine different modes of articulating self-knowledge. Foucault did not conceive this hermeneutics of desire in the Greco-Roman Antiquity and in early Christianity in terms of continuity or evolution. Likewise, it would be a mistake to try to put together a general "history of the medical gaze" from the texts discussed in this chapter, or to present the story of a progressive "medicalization" of the aging male body and mind during the Renaissance. Far from trying to provide a linear perspective on this issue, I have emphasized the heterogeneity of interventions carried out in the name of health in later life. Building on Foucault's analyses of practices of self-reflection from the Hellenistic and Roman periods, this chapter has expanded the framing notion of care of the self in time and in scope. As more people from the upper classes of both sides of the Alps grew old during the Renaissance, longevity went along with an interest in practices associated with the care of the aging self. All the writers considered here strove to maintain optimal well-being in the face of age-related losses. Some, such as Petrarch and Erasmus, focus on an increasing spiritual

78 Sharon Kaufman, The Ageless Self. Sources and Meaning in Later Life (Madison: University of Wisconsin Press, 1995), pp. 10-20. See also chapter 4, section 3 of this work. 
awareness in later life. Their faith served as a buffer against physical losses; consequently, their experience of growing old epitomized a move from earthly values to a higher level of consciousness of human finitude and God's perfection. In fact, both writers' self-portraits challenge Foucault's distinction between the Greek ethics of self-constitution on the one hand and, on the other hand, the Christian forms of morality requiring submission to a divine law: both aspects go hand in hand.

Yet, as Erasmus's Praise of Folly ironically observes, the old man may perhaps enjoy the benefits of long experience, but what is the nature of his wisdom? Age decreases his cognitive capacities and brings changes in his personality, undermining the vision of life as a progressive improvement. There is no guarantee that extended life will bring any gain, unless supportive conditions promote this goal. The care of the self is one of these basic conditions. The elder became the object of a medical gaze in Zerbi's and Ficino's treatises, and the care of the self became part of a broader work of self-fashioning that combined bookish knowledge with experience.

In Erasmus's Praise of Folly, as in Montaigne's chapter "Of Experience" in the Essais, there is an increasing integration of divergent elementsrational, physical, and emotional — when referring to the process of aging. Erasmus describes such integration paradoxically as a way to maintain critical engagement with the self, others, and the world. Montaigne, on the other hand, confronts the negative aspects of his experience of growing old and tries to embrace them in a pragmatic way. His ailing and aging body fills him with despair, yet this also stimulates his imagination and his irony. Both Erasmus and Montaigne cope with the woes of old age instead of denying them. By different means, Petrarch, Erasmus, and Montaigne attain new levels of growth in later life, and a better understanding of the mind-body relationship. Their physical health may be poor, but nevertheless they rejoice in the self-knowledge gained from it.

In some way, the authors discussed in this chapter portray themselves as active participants in the process of aging. No one went further in this direction than Cornaro who saw old age as a mode of being based on strict self-regulatory practices. His regimen shapes his individual behavior and mood. As he notes, the food we eat, the physical and intellectual exercises we perform are part of what Foucault calls a "culture de soi." Cornaro is more categorical than Ficino and Zerbi in his claim that old age is a work of art. Echoing Galen and Hippocrates, all three writers contend that each person bears full responsibility for his later life. Like Petrarch, Ficino, Zerbi, and Montaigne, Cornaro's moral stylization of existence depends on 
pragmatic ways to delay the decline of physical and cognitive capacities. To some extent, however, salvation seems to take on the secular meaning of "health" in Cornaro's treatise.

Attention to self, physical and intellectual self-mastery, and moderation are essential philosophical attitudes. Habits in eating, drinking, sleeping, and similar basic daily functions not only establish a "lifestyle"; they also require a sharp focus on the present moment. In this respect, the vogue of health regimens from the fifteenth century on capitalized on the Stoic and Epicurean urge to find happiness in the here and now. ${ }^{79}$ In De Brevitate Vitae, Seneca noted that instead of complaining about human existence's brevity, one should use time efficiently to extend life. Freedom from care is the essence of any regimen to prolong life. Yet the personal aspect of health care is not the whole story of old age. In Petrarch's and Montaigne's time of wars and moral disarray, attention was directed again toward the connection between good government of both the human body and the body politic, as we shall see in the next chapter.

79 See chapter 4, section 3 of this study. 


\section{THE CIRCULATION OF POWER AND KNOWLEDGE}

In the humoral theory discussed in the previous chapter, a set of physiological factors determine a diffuse pattern of individual and social behavior at each stage of life. The young man whose body has too much heat is likely to be vulnerable to passions, his impulsive reactions can have dangerous consequences when it comes to governing others. By contrast, the elder (throughout this chapter I will speak of the "riper" man, not the decrepit one on his deathbed) being cooler, is more prudent and rational; his self-control is a major asset when it comes to making wise decisions for the common welfare. ${ }^{1}$

In every society, age serves as a basis for the allocation of different roles that define its members' mutual relations and activities. Sociologist Max Weber observed that in a conservative community that identifies itself with its past, the aged man expects obedience from the young because the social criteria for excellence include knowledge, experience, and spiritual and moral resources. ${ }^{2}$ On the other hand, in a milieu where military values prevail, the emphasis is on youthful, physical vigor. Old age, then, initiates a process of disengagement from an earlier role: the elder's diminished position and status go along with limited social opportunities or withdrawal from the public sphere, and resignation in the face of loss. Renaissance Italian and French societies corresponded more or less to traditional age-grade systems favoring the elderly. Since Antiquity, an adult man kept his rights (legal, financial, political, civil, and professional) up to his death and appointments could be made at advanced ages. The notion of retirement (and of funds given to retirees by the state) became official only in eighteenth-century France; ${ }^{3}$ before that time, the privileges accorded to the elderly generally took the form of exemption from certain dutiessome forms of military service, for instance—rather than positive benefits. ${ }^{4}$

1 See chapter 1.

2 Max Weber, The Theory of Social and Economic Organization, transl. A.-M. Henderson and T. Parsons (New York: Free Press, 1947) p. 346.

3 See Troyansky, Old Age in the Old Regime, p. 56.

${ }_{4}$ Exemptions from different forms of military service were usually granted to those who had reached the age of sixty, or sometimes seventy. See Sulamit Shahar, "The Middle Ages and Renaissance", p. 75 . 
In any society there are relations of power that permeate and constitute the social body, Foucault observes. By "power," he meant a cluster of relations, a heterogeneous ensemble of strategies and techniques continually at work in human exchanges rather than an exterior force imposed upon an individual. His work focused on the practices and the effects of this micro-physics of power: on the way things "work at the level of ongoing subjugation, at the level of those continuous and uninterrupted processes which subject our bodies, govern our gestures, dictate our behaviors, etc." Although the exercise of power remains linked to individuals, it is not tied to specific persons, Foucault contends; in fact, it is the other way around: individuals depend on power relations in order to define themselves. The instability and reversibility of these relations allow creative responses and resistances to power. ${ }^{6}$ Indeed, power is not necessarily repressive, but is also productive of knowledge. Foucault's discussion of the confession ritual and of the prohibition of some sexual behaviors provides suggestive examples of mechanisms of power and surveillance that put into circulation apparatuses of knowledge conceived in terms of social relationships. Rather than seek to eradicate the repressed phenomenon, these mechanisms reveal it, keep it alive, and acknowledge its constitutive role.

This chapter elaborates on Foucault's investigation of the relations between power and knowledge in a different field: it examines the young-versus-old confrontation in the body of the Renaissance ruling and intellectual elite of both sides of the Alps. My goal is to show how these relations open themselves up to various forms of self-fashioning and self-knowledge. Moreover, their political impact deserves scrutiny: at stake was nothing less than social harmony and peace. In this respect, the proliferation of Renaissance representations of old men as advisors, councilors, and pedagogues takes its full meaning in the perspective of the previous chapter. The care for the self appears like a pedagogical, moral, and also ontological condition for the constitution of a good leader. Since one must first establish a proper relationship to oneself in order to be capable of exercising power over others, the elder is in an ideal "position" to shape the body politic and direct the behavior of others by passing on

5 M. Foucault, “Two Lectures”, in Michel Foucault: Power/ Knowledge: Selected Interviews and Other Writings, 1972-1977, ed. C. Gordon (Brighton: Harvester Press, 1980), p. 97. See also Foucault, The History of Sexuality, vol. 1, p. 93 defining power as "a complex strategic situation in a particular society."

6 Foucault, The History of Sexuality, vol. 1, p. 93. 
to the young generation the knowledge of some rules and the practices that these rules regulate.

Portraits of old men as educators drew upon a wide variety of classical, medieval, and biblical sources; yet it is safe to say that every defense of old age referred to Cato Maior De Senectute, in one way or another. Cicero's dialogue confers upon the octogenarian Cato the Elder the role of pilot of the ship of the state and praises a lifelong practice of virtues that confers dignity at the end of a long and honorable career. The number of editions, comments, and translations of Cicero's dialogue during the Renaissance attests to its immense popularity as well as to its author's reputation. Learned people could easily identify in De Senectute's emphasis on Cato's pivotal function in the social and political spheres the imprint of a philosophical and medical tradition that included Plato and Hippocrates. In addition, they could find many similarities between Cato the Elder's belief in the soul's immortality and their own Christian background. A remark made by one of the protagonists of Erasmus's colloquium Convivium religiosum (The Godly Feast) could epitomize this perspective. Commenting on Cato the Elder's words in De Senectute, Chrysoglottus says:

While most of Marcus Tullius [Cicero] books on philosophy seem to breathe something of divinity, I consider the one on old age, written when he himself was old, his swan song, as the Greek proverb puts it. Today I reread it and learned the following words by heart, since they pleased me most of all: "... I depart from this life as from an inn, not from a home. Nature gave us a lodging to stop at, not to settle down in. O glorious day when I shall join that company of souls and leave this tumult and contagion!" Thus far Cato. What could a Christian have said more reverently? I wish the conversations of monks, or those of monks and nuns, were all like this talk of an old pagan with young pagans. ${ }^{7}$

More broadly speaking, De Senectute gave generations of readers a stock of philosophical, political, and rhetorical arguments to support the view that the management of affairs of state and the education of the young should be the elders' specific tasks. In Cicero's text the octogenarian Cato the Elder is no longer able to participate in physical military activities, but his later years mark his transition to a more valued public role: old age is a period of enhancement and opportunities, rather than diminution and loss. Cato embodies his fellow citizens' political expectations; in fact, he lives for the common good rather than for himself. He is a role model in

7 Erasmus, Convivium religiosum in The Complete Works, vol. 39, Colloquies, ed. and trans. C. R. Thompson (Toronto: Toronto University Press, 1997), pp. 192-93. 
his community and his prestige extends beyond the political arena to the private domain of everyday life. Not only does he perform important functions in advisory councils, he also teaches the young generation, and his own emploi du temps is exemplary. In short, his speaking ability and wise counsels, his activities and even his leisure shape every aspect of Rome's public life.

The most astute Renaissance writers did not simply reproduce $D e$ Senectute's arguments (to which I shall return later) but combined them with other sources, transposed them to their own historical context and to other circumstances, challenged them or ironically subverted them. Here I would like to examine new forms of elders' identities that emerged from Petrarch's Letters of Old Age, Castiglione's Book of the Courtier, and Montaigne's Essais. In a period of political turmoil and especially in the context of the civil wars of Montaigne's late sixteenth-century France, the circulation of power and knowledge between generations became an increasing matter of concern. Montaigne's views on age and intergenerational relations take their full meaning when considered in this broader intellectual context.

\section{Petrarch}

Petrarch shared Cato the Elder's belief in De Senectute that those advanced in years have a crucial role in the perpetuation of a society's moral, cultural, and sacred heritage. He was, however, strongly critical of Cicero for having wished in his later years to return to a life of politics, with its many useless quarrels; such a choice is inappropriate for a scholar and a sage, he contended (Fam. XXIV, 3). Yet his epistolary work reflects his attempt to exert political influence at the highest levels, while at the same time preserving his intellectual independence and inhabiting a world of literary, moral, and spiritual reflection. His emphasis on his age in the Letters of Old Age fully participated in this dual goal.

My argument will focus on three broad perspectives. First, Petrarch's relations with Pope Urban V regarding the return of the Holy See to Rome, on the one hand, and his discussion of the best government in a letter to Francesco da Carrara on the other hand, will serve as case studies of the literary and psychological effects of the author's self-portrait as an aged man. Second, any investigation of Petrarch's self-portraits in his epistolary work is bound to be incomplete if attention is not paid to the dispositio of his letters. At first glance, the organization of the Letters of Old Age 
seems to reflect the randomness of a writer somehow caught up in his addressees' lives and in current concerns. A closer look, however, reveals a careful orchestration in the letter series that placed Petrarch at the center of a network of relations of power and knowledge between one generation and another. Third, by focusing on his experience of aging, Petrarch insured a bond with dead, living, and unborn correspondents, and paved the way for his own immortality. At all three levels, the fashioning of an aging identity was a crucial aspect of a process of self-understanding. The comparison between the Letters of Old Age and De Remediis utriusque fortunae (written about the same time) provides a suggestive way of examining further implications of this question.

As he became more famous in his later years, Petrarch acquired a correspondingly elevated sense of his own public status in the ever-changing cycle of events, even if he was unable to control them. In the second letter of book I's Letters of Old Age, he told his friend Francesco Nelli that the Roman Emperor Charles IV and the French King John II both summoned him to work for them; the emperor even gave him a golden bowl as an advance. If these invitations were not enough, Pope Innocent VI (Urban V's predecessor) asked him to become his secretary, and sent him some gifts. Petrarch's letter is dated sometime between 1361 and 1362 , when he was age fifty-seven or fifty-eight. He joked about his age and wrote to Nelli that old men are often accused of avarice, but such was not his case. The elders, he added, are also said to be more obedient than young ones, yet he had no intention of accepting any of these positions (Sen. I, 2, pp. 3-5/ Lettres, vol. 1, pp. 23-27). The three offers stressed his international reputation, but more was at stake in the letter than the desire to boast of his prestige among the religious and political elite. The following letter to the same correspondent (dated from Padua, June 8, 1362), placed these invitations in the context of the day. War was raging everywhere, and the roads around Padua were blocked in whichever direction Petrarch tried to go. There was turmoil in Venice and in Western Lombardy; there was fighting in Tyrol and it was impossible to travel to the emperor's court in Bohemia because the German border along the Alps was not safe (Sen. I, 3, p. 10/ Lettres, vol. 1, pp. 37-41).

In his response to the offer from the papal court, the writer adopted the posture of a wise and experienced aged counselor. His lifelong experience was coupled with stereotypical qualities such as a sound judgment and frankness. In fact, he contended that telling the truth was not only an aged man's right but also his duty. He officially declined the pontifical secretary position in book I's fourth letter (addressed to Cardinal Elie de 
Talleyrand, Bishop of Albano). The humanist stressed his age, and therefore his lack of interest in honor and wealth. More importantly, he pointed out the atmosphere of calumny, hypocrisy, and hatred at the papal court. A position in such a milieu would seriously have limited Petrarch's freedom of speech, preventing him from acting according to his own moral precepts. Book I's fifth letter to Boccaccio summed up his general feeling: he was disgusted with Italian politics and firmly determined to stay away from that atmosphere of envy and corruption (Sen. I, 5, p.15/ Lettres, vol. 1, pp. 47-48). His desire to spend his later years in a studious retreat revealed the intellectual independence of a man who had only contempt for earthly vanity. Petrarch's personal life reinforced his wish to withdraw from the public sphere: death looms over the Letters of Old Age from the onset. In book I's opening letter to Nelli, Petrarch mourned the death of many close friends, and of his own son Giovanni (Sen. I, 1). Indeed, old age is traditionally a time of loneliness; in addition to the loss of loved ones, one's own end seems more and more imminent.

However, Petrarch's preparation for the afterlife and his concern for literary immortality did not exclude his involvement in public affairs. The election, on September 28, 1362, of Pope Urban V (Guillaume de Grimoard) as successor to Innocent VI increased Petrarch's hope to renew the Church, and to bring unity and peace to Italy. He trusted the new pontiff's moral rectitude and reputation for integrity. For Petrarch, the government of self was the predicate for any constructive engagement with social institutions. Urban V was in his fifties, the "prime" of old age"green old age" as Galenic medicine put it — that is, at an age when wisdom and prudence are predominant in a man's general behavior. ${ }^{8}$ The Letters of Old Age's book VII contains only one letter, dated June 29, 1366 (four years after the Pope's election) urging Urban V to leave Avignon, which had been the papal residence since August 1308, and return the Holy See to Rome at once. Throughout this long letter, Petrarch established himself as a perceptive commentator on human nature, rather than as a political analyst; a wise and experienced aged moralist pinning his hopes on virtuous individuals as the best means of promoting security and faith. Following up on his appreciation for Urban V's affable manners, the writer praises the pope's battle against self-promotion and corruption in the Church (Sen. VII, 1, p. 229/ Lettres, vol. 2, p. 303). The pope's name (Urbanus: urban, gentle), Petrarch noted, was the very sign of his virtues,

8 See chapter 1, the section on Petrarch. 
and therefore of his ability to champion faith. Moreover, who could deny that his name signaled his attachment to the city (urbs) of Rome? (Sen. VII, 1, p. 236). ${ }^{9}$

The letter gave a bleak image of the political and moral climate of the day. Rome was in ruins, its temples crumbling; vice ruled the Eternal City; the Church members delighted in sensual pleasures, and were more interested in wine than in religion. To this general disarray, Petrarch added an international threat: the Turks were fighting Christendom. God himself urged the Holy See to return to Rome. After such an ardent plea, any reader would have been inclined to bestow the pope's official title of "Vicar of Christ" on the sixty-two-year-old Petrarch rather than on Urban V. The writer portrayed himself as the ambassador of the Christian community as a whole, for in his view his letter met Christ's expectation and approval. He closely monitored the way his behavior would be perceived by his readers; his plea to Urban V conveyed his loyalty to his country and his Christian devotion. The contrast was striking between his unselfish concern for the common good and for God on the one hand, and on the other hand, the corruption of the ambitious flatterers who filled the papal court. From the outset, he told the pope that he had a longtime habit of being outspoken with both important and less important people, but especially with the more powerful ones who, he hoped, would reward his frankness and forgive his mistakes (Sen. VII, 1, p. 228). ${ }^{10}$ Politics is a struggle for power, yet it must be tempered by a will to listen to a truth that may be difficult to embrace. Petrarch's freedom of expression and independence of mind were inseparable from the exercise of an auctoritas traditionally granted to the elder. Indeed, he pointed out "Solon's famous answer to Pisistratus" (quoted in Cicero's De Senectute (20, 72, p. 84)), along with a similar story told by Valerius Maximus (VI, 2, 10):

When asked by Pisistratus, the tyrant of Athens, how he had the nerve to stand up to him so steadfastly, he answered, "Because of my old age." Then there is that saying of Marcus Castricius, with different words but the same idea; when the angry Carbo, consul in name but tyrant in reality, said

9 "Quomodo enim, queso, et Urbanus diceris et, nominis huius originem, Urbem fugis?" (Lettres vol. 2, p. 321).

10 "consuetudo mea scribendi non tantum pari fidutia parvis ac magnis, sed eo semper alacrius quo maioribus sim scripturus, a quibus et bene dictorum ampliorem gratiam et errorum promptiorem veniam sperem." (Lettres, vol. 2, p. 299). 
threateningly that he had many swords, he replied, "And I have many years." (Sen. VII, 1, p. 228). ${ }^{11}$

The self-control of Pisistratus and Marcus Castricius commanded respect. Petrarch shared these old men's determination and their proud refusal of any form of threat or enslavement. He even perfected their exemplary attitude, since his position embodied classical (pagan) ethical ideals as well as religious virtues: he represented himself as a Christian Ancient. Old age justified his "frankness or truthfulness, nerve or conviction;" moreover, it served as justification for the length of his exhortation to the pope (Sen.VII, 1 , p. 244/ Lettres, vol. 2, p. 373) since loquacity is a stereotypical attribute of old age. In speaking the truth, Petrarch does not simply invite the pope to act, but also reveals to the reader who he is: a man whose ethical priorities and religious principles shape his relationship to himself and to others. Ultimately, the objective of his frankness is not so much the salvation of Rome as a matter of self-fashioning: speaking the truth finds its fulfillment in the "formation of a certain way of being, a certain way of doing, a certain way of conducting oneself around other people or another person," in Foucault's words. ${ }^{12}$

Now a letter is a delayed exchange between two parties who occupy separate and often distant positions in space and in time. Since the writer communicates his views without interruption, challenge, or reaction from his correspondent, he should be circumspect about the wording of his text. Petrarch took some precautions to ensure the positive reception of his plea: he asked Francesco Bruni (one of his Florentine admirers, who became papal secretary after Petrarch declined the position) to solicit the advice of two of Petrarch's close friends (Philippe de Cabassoles and Agapito Colonna) before sending the letter to Urban V. ${ }^{13}$ The letter was well received. After numerous consultations with members of the French and Italian clergy, Urban V left Avignon a few months later, on April 30, 1367.

The Letters of Old Age's book IX contains only two letters commenting on this event: first, an enthusiastic letter to the pope hailing his return to Rome and praising the triumph of faith and virtue over vice (Sen. IX, 1);

11 "Unde est responsum illud famosissimum Solonis: quem cum Pisistratus Atheniensium tyrannus interrogaret qua fidutia sibi tam constanter obsisteret, "Senectute", inquit. Et illud Marci Castricii, verbo aliud, idem sensu; cui cum iratus Carbo, consul nomine, re tyrannus, inter minas diceret "multos se gladios habere", respondit: "Et ego annos." (Lettres vol. 2, p. 301).

12 M. Foucault, Cours au Collège de France 1984. Le gouvernement de soi et des autres II (Paris: Gallimard, 1984), 8 février. My translation.

13 Petrarch, Lettres, vol. 2, p. 296. 
second, a more personal letter to Francesco Bruni stressing Petrarch's role in this victory (Sen. IX, 2). From books VII and IX of the Letters of Old Age's account, it was clear that Petrarch masterminded the whole operation from beginning to end; the pope had only carried out the humanist's plan. Petrarch's joy, however, was brief. Fleeing the political turmoil of Rome, Urban V returned to Avignon in 1370, and soon passed away. Two letters in book XIII elaborated on these developments. Letter 12 to Philippe de Cabassoles (dated between 1372 and 1373) echoed a previous letter to him written during Innocent VI's papacy (Sen. I, 4): Petrarch declined yet another invitation to work at the papal court and expressed his bitterness. He had no respect for the circle of hateful and envious advisors surrounding the new pontiff Gregory XI. In his next letter to his friend Bruni, he was convinced that the cardinals the pope had just appointed would speak against his own faithful devotion to the Church (Sen. XIII, 13, p. 507). ${ }^{14}$ In fact, he did not trust Gregory XI, he wrote to Bruni. Thinking about his hope at the time of Urban V's election (Sen. XIII, 14, p. 513/ Lettres, vol. 4, pp. 197-99), he wished the deceased pope could have read his letter of reproach for having abandoned Rome. He was convinced that Urban V would have taken action, as he had after receiving Petrarch's plea to leave Avignon (the French Babylon) in 1366 (Sen. VII, 1). The virtuous Urban V was the only one who could have saved the Church, but he had been caught between conflicting interests and had been the victim of deceitful advisors as well as venomous enemies. Was the pontiff's subsequent death due to poison? Petrarch did not rule out a plot by some members of the papal court, given the Church's spiritual disintegration (Sen. XIII, 14, p. 515/ Lettres, vol. 4, p. 211).

About two years after these tragic events, he had abandoned all hope for moral and political action. Once again, his age became the pretext for promoting his studious retreat and his preparation of the afterlife. Yet might there be a second evaluation of Petrarch's old age, at odds with this flattering self-portrait blending pagan and Christian ideals? To what extent did his letters reflect his frustration and his feeling of living in exile? His lifelong experience and erudition had proved useless when it came to dealing with the Church's spiritual crisis. His failed embassy and subsequent retreat acknowledged a gap: he belonged to a past generation,

\footnotetext{
14 "credere te papam optime voluntatis erga me, veruntamen, propter turbam famelicorum cardinalium quos de profundis ad eum statum nuper assumpserat, nec voluntatem in actum traducendam nec magnificum inde michi nunc aliquid te sperare." (Lettres, vol. 4, p. 193)
} 
whose ethical and Christian values lacked respect among powerful contemporaries. He wrote to Francesco Nelli $($ Sen. I, 3) that his enemies might have found him too old and physically weak to hold the influential position of apostolic secretary, yet he was strong enough for peaceful labors.

Never did Cato the Elder have to confront such problem in Cicero's De Senectute: at age eighty-four he was the indisputable center of Rome's public life. As such, he conveyed Cicero's personal ambitions of power at the very moment when the sexagenarian author was losing his political influence. De Senectute's eloquent defense of gerontocracy expressed Cicero's own frustrations; Petrarch's reactions were very different, at least as portrayed in his letters concerning the return of the Holy See to Rome. In the context of a political crisis that he saw mostly in moral terms, the posture of Petrarch the old man conveyed both his lucid view of the situation and his limited power of action. In contrast to Cato the Elder's proud authority over his fellow citizens, growing old taught Petrarch patience as he witnessed with increasing irritation and sadness the spiritual and political turmoil of the day.

In fact, he gave his readers the point of view of an aged letter-writer who had assigned himself the only field of public life worthy of him: the wider regions of immortal and universal fame. As Seneca observed in his Letters to Lucilius (a major reference of Petrarch's correspondence), the wise old man is never apart from public life even if he withdraws. Perhaps "he has abandoned one little corner thereof," but he is in fact above it:

he understands how lowly was the place in which he sat when he mounted the curule chair or the judgment-seat. Lay this to heart-that the wise man is never more active in affairs than when things divine as well as things human have come within his ken. (LXVIII, 2, p. 45)

Other epistles in Letters of Old Age elaborated on a similar view and conveyed the way Petrarch saw the role of literature in the political sphere. Book XIV, for instance, contains two letters to Francesco da Carrara, Lord of Padua, that define Petrarch's conception of the best government. In book VII, the humanist gave Urban V no practical advice for fighting vice and corruption in the Church; likewise, book XIV offers few insights on the state's administrative structure, inasmuch as political questions are associated to certain forms of self-relation. For Petrarch, the best form of government depends on the prince's personal qualities, and Francesco da Carrara embodied all of them. The enumeration of his virtues (moral rectitude, constancy, fairness, faith, magnanimity, humility, mercy, paternal love for one's fellow citizens, concern for the common good, and so on) 
mostly followed medieval advice books for city magistrates, and Roman sources, including Seneca. ${ }^{15}$ Once again, Petrarch avoided accusations of being a flatterer by affirming his commitment to truth. The end of his second letter to Francesco da Carrara struck a tragic tone in this respect, for it alluded to a failed attempt to poison Francesco (Sen. XIV, 2, p. 555/ Lettres, vol. 4, p. 313). The presumed author of the plot was Francesco's own brother whose name Petrarch purposely omitted since he did not deserve to be remembered.

We cannot deny that there was a strong element of status-granting in Petrarch's representations of Francesco da Carrara and Urban V as virtuous and dedicated leaders. In both cases, Petrarch's self-portrait in old age offered resistance to a context deprived of moral and religious values. Instead of sliding into old age, the writer showed himself ascending to it after the slippery journey of youth and its clouds of passions. His choice of life and the way he managed the only things that depended on him-his body, his mind, and most importantly, his time-commanded respect. ${ }^{16}$ Like Cato the Elder in Cicero's De Senectute, Petrarch's age served to justify his freedom of expression and his constancy, to establish his moral credentials as a purveyor of true representation, and to deflect the accusation of flattery that was always suspected behind the panegyrics of powerful men. Moreover, as a man dedicated to scholarship, he had read and meditated upon countless historical accounts; he therefore understood contemporary politics within a broader intellectual context.

Far from being unmoved by the pettiness and vices of a world he was about to leave, Petrarch forged links with Cicero. The sexagenarian Roman had written De Senectute to persuade the Senate to continue to retain his services. Petrarch, on the other hand, declined the opportunity to stay in office in his later years; yet, like Cicero, he used his eloquence, his age, and his reputation to advocate peace. His correspondence with Urban V and Francesco da Carrara testify to his relentless efforts to motivate members of the religious and political elite, and to foster cooperation when it seemed most difficult. In these letters - and throughout his Letters of Old Age as a whole - he gave advice and urged his contemporaries to withstand the blows of fortune by cleaving to virtue and overcoming libidinous

15 On medieval advice books, see Paul-Oskar Kristeller, Studies in Renaissance Thought and Letters (Rome: Edizione di storia e letteratura, 1956), pp. 262, 56o-64. On Petrarch and Seneca, see P. Stacey, Roman Monarchy and the Renaissance Prince (Cambridge: Cambridge University Press, 2007), pp. 119-20, 140-56.

16 See chapter 1 , the section on Petrarch. 
attachments to secular things. With paternal authority, he attempted to prepare them for public service, embodying the elder's moral responsibility to instruct youth. His letters to members of the young generation such as Giovanni Boccaccio, Francesco Bruni, and Philippe de Cabassoles show him as a teacher and father figure imparting a variety of notions and skills, ranging from the acquisition of a literary style to the cultivation of moral and religious values. To his correspondents (and to the wider audience of his epistolary works) he passed along a Christian and classical heritage in which he included himself.

Book VIII of the Letters of Old Age provides us with yet another aspect of Petrarch's fashioning of his self-portrait in later life. This aspect is unrelated to De Senectute's model for it deals with the series on the construction of letters. Book VIII contains eight letters that appear in chronological order (with the exception of letters two and three); all are written in Pavia (though the seventh letter does not indicate location) over a period of exactly one year. The first, to Boccaccio, is dated July 20, 1366 at dawn, on Petrarch's sixty-third birthday. The eighth letter, to the same recipient, is written one year later, on July 20, 1367 at dawn, on Petrarch's sixty-fourth birthday.

The first letter begins with general considerations on young and old people's respective tendency to lie about their age, or to hide it, as Petrarch himself used to do. The author reminds Boccaccio that the ancient authorities held various views regarding the onset of old age. He then focuses on an ancient Roman superstition. According to Julius Firminus Maternus and other sources, the seventh and ninth years of life are said to bring destruction, hence the sixty-third one is doubly evil, being the product of two unlucky numbers (Sen. VIII, 1 p. 263/ Lettres, vol. 3, p. 29). Among the dangers that await a person entering the climacteric year are "enormous disaster or death, or physical or mental illness" ("insigni calamitate aliqua vel morte vel morbo corporis aut animi") (Sen. VIII, 1, p. 266/ Lettres, vol. 3, p. 29). Having just entered the dreaded sixty-third year, Petrarch allegedly "disdain[s] the entire matter, and the explanation of it just as much" (Sen. VIII, 1, p. 266/ Lettres, vol. 3, p. 29), and claims that he has never felt so well as on this birthday; moreover, he has no fear of death. Despite his criticism of astrology, however, he was not completely free from anxiety. Book VIII's final letter to Boccaccio expresses his relief at having survived the critical year. He then unmasks the fallacy of superstitions and looks back with amusement and tolerance at his fears. In conclusion, he thanks God who granted him protection, although he does not expect to live forever. He also celebrates the triumph of faith over paganism and 
superstition in the world at large by praising the Christian king of Cyprus's victory in Alexandria, and the return of Pope Urban V to Rome (Sen. VIII, 8, p. 303/ Lettres, vol. 3, p. 103). Ironically, numerological superstitions were at work at the very moment he dismissed them since the news of his sixty-fourth birthday appears in the eighth letter of book VIII: eight times eight make sixty-four.

Cicero was sixty-two years old when he wrote his famous apology of old age in De Senectute; he was killed two years later. Petrarch, however, had read that Cicero had lived sixty-three years. ${ }^{17}$ Book VIII's second (and probably fictitious) letter, to "Unspecified Friends," was Petrarch's own version of Cicero's apology of the twilight years; moreover, he wrote it when he was about the same age as the Roman senator. In De Senectute, Cato the Elder gave four broad reasons that make people fear old age: first, it takes away active work; second, it weakens the body; third, it deprives man of pleasure; fourth, it is not far from death. He countered each in turn. Petrarch's Letters of Old Age, book VIII's second epistle revisited these questions, taking into account other sources of inspiration, including Seneca's Letters to Lucilius. The humanist reiterated Seneca's statement that "life is most delightful when it is on the downward slope, but has not yet reached the abrupt decline" (Ad Lucilium XII, 5, p. 67). Having reached the first phase of old age (Galen's "green age"), he felt in a riper, peaceful and milder season than the previous stages of his life. To a friend who tried to comfort him because of his age, he replied, "if you care for me, do not weep because I am not young; weep because I once was" (Sen. VIII, 2, p. 273). ${ }^{18}$ Looking back on his life as a whole, he could see that he had wasted his youth in the turmoil of his passion for Laura. After this period of "civil war" and inner struggles, he had finally found harmony and peace in his later years. Although he felt physically weaker than in his youth (a physiological fact that Cato the Elder flatly denied in De Senectute), his memory was still excellent. Following Cato's example, he maintained a high level of energy by fasting, and reducing his hours of sleep, and contended that everyone should get into such habits of healthy living and moderation in diet from his earlier years onward. Like Cato, he was convinced that only fools ascribe vices and follies to the winter of life. As Cicero's dialogue made clear, senile debility and melancholy result

17 See Lettres, vol. 4, p. 539 fn. 79 about Petrarch's source (Seneca, Suas. 6, 22).

18 "Noli", "inquam," amice, si me amas, flere quod iuvenis non sum; "fle potius quod iuvenis fui!" (Lettres, vol. 3, p. 43). 
not from the condition of age itself, but from personal weaknesses and bad habits. Cato saw old age as a liberation from the sexual appetite that troubled him earlier in life; thanks to this harmony he enjoyed a serenity unavailable to those still prey to their instincts. Petrarch, on the other hand, still felt the attraction of sensual love, but was no longer subject to its constraints, and was therefore able to focus his attention on intellectual activities. His vast correspondence, and his revisions and completion of previous works were the products of the energy of his later years. His pleasures were perhaps fewer than in his youth, but more meaningful. "Let us cherish and love old age; for it is full of pleasure if one knows how to use it," Seneca likewise observed in his Letters to Lucilius. "Fruits are most welcome when almost over; youth is most charming at its close; the last drink delights the toper... Each pleasure reserves to the end the greatest delights which it contains." (VII, 5, p. 67). Finally, approaching death did not worry Petrarch since the soul is immortal, as Cato the Elder contended in Cicero's De Senectute. In this respect, Petrarch firmly rejected Seneca's temptation to suicide (Ad Luc. LXXVII).

Throughout book VIII's eight letters, there is a continuing resonance of the Ciceronian and Senecan representation of old age as a period of dignity, serenity, wisdom, and inner freedom for a self-motivated man. In this respect, the eight letters echo a series of philosophical commonplaces on later life: they speak of the fallacy of superstition (Sen. VIII, 1), the benefits of old age (Sen. VIII, 2), the widespread and wrong belief in fortune's adversity and in opinions (Sen. VIII, 3), and the importance of friendship (Sen. VIII, 4). They offer thoughts on how to bear grief (Sen. VIII, 5), on preparation for the afterlife through penance and reading (Sen. VIII, 6), and they praise the benefits of a peaceful and solitary retreat in the countryside as opposed to the tensions of an urban lifestyle (Sen. VIII, 7). In contrast to Cato the Elder's exemplary character and role model, Petrarch's self-portrait embodies the will and effort to acquire the values prescribed for the younger generation. Petrarch's smile when describing his superstitious fear of the ominous sixty-third year of his life (Sen. VIII, 1 and 8) epitomizes this attitude. As he grew old, Petrarch had a better understanding of himself; he knew how to judge his past, and rejoiced at having overcome his youthful inner struggles. ${ }^{19}$ As Saint Augustine (another influential model for Petrarch) observed in his sermon Ad Competentes, the wisdom of old age is not a matter of

19 See also chapter 3 , the section on Petrarch. 
being more experienced, but of gradually discerning the meaning of those experiences. As we grow old, we do not "lose" the previous ages we lived, but we see them differently:

By means of these divisions or stages of age, you will not change from one stage to another, but staying the same, you will always know newness. For the second age will not follow so that an end may be put to the first; nor will the rise of the third mean the ruin of the second; nor will the fourth be born so that the third may die; nor will the fifth envy the staying power of the fourth; nor will the sixth suppress the fifth. Although these ages do not all come into being at one and the same, they continue together in harmony with one another in the soul whose relationship with God is right, and they will conduct you to the everlasting peace and tranquility of the seventh stage. ${ }^{20}$

In Augustine's perspective, the advancing from one age to another is a sort of death; hence this process liberates man from the fear of his "real" death, which only involves a migration to a new and better life. In his Letters of Old Age, Petrarch achieved Augustine's measure of transcendence while being at the same time attentive to the political instability and moral corruption of the day.

The final book of the Letters of Old Age contains only one letter, dedicated to "Posterity," which looks forward in time to unborn readers (Sen. XVIII, 1). In contrast, the last epistles of the Letters on Familiar Matters look backward since all their addressees are the Ancients whom Petrarch emulated (Cicero, Seneca, Varro, Quintilian, Livy, Pollio, Horace, Virgil, Fam. XXIV, 3-11). Together, the endings of the two collections secured Petrarch's position in a Republic of Letters unaffected by time. Scholarly interest in the letter to "Posterity" has focused on the details of Petrarch's life of exiles and travels, as well as on his friends and correspondents; I will leave it to others to discuss these aspects of his life. My aim is to suggest a dimension unexplored by scholars: the impact of the aging process on the autobiographical narrative that concludes the Seniles. The final letter to "Posterity" was written between 1370 and 1374, in the last four years of Petrarch's life. From the outset, the author stressed his physical decline. His dim vision forced him to wear glasses; old age has "invaded [his] body which had been very healthy in every age, and surrounded it with the usual array of ills" (XVIII, 1, p. 672). His emphasis on his aged and

20 The passage appears in Saint Augustine, Sermo 216 Ad Competentes, in Patrologia Latina (Paris: Migne, 1863sq.), vol. 178, col. 731. English trans. M. Dove, The Perfect Age of Man's Life (Cambridge: Cambridge University Press, 1986), pp. 48-49. 
weak body stands in sharp contrast with his lust for literary immortality. As evidenced by its full title- "An account of [Petrarch's] background, conduct, and the development of his character and studies" - the letter offers a coherent narrative of its author's life. It retroactively confers meaning on a sequence of events which, no doubt, had different and more complex reasons when they occurred. Petrarch summed up the path of his literary career, settled old scores, repaid some debts, recalled his disappointment when Pope Urban V returned to Avignon, and paid tribute to his patrons, including the Carrara family.

David Guttmann, who has studied cross-cultural patterns of aging, notes that the process of a "life review" occurs often at old age, and is "prompted by the realization of approaching dissolution and death, and the inability to maintain one's sense of personal invulnerability." The autobiographical narrative moves the elder toward "personality reorganization" and provides him with a greater sense of meaning in his life. ${ }^{21}$ In the same way, the letter to "Posterity" represents Petrarch's life as a total history. Its goal is very different from a faithful biographical account; indeed, from its dedication on, the letter situates the writer's persona at the threshold between life and death. With his end approaching, Petrarch portrays himself looking back on his past and forward to what will come next: death and the afterlife, along with ways to secure his literary immortality. His Janus-like perspective in this final letter is an adaptive move to escape oblivion since it allows the aged Petrarch to represent himself as an old and famous writer full of wisdom, experience, serenity, and faith, who has achieved an enviable proximity to God. The purpose of this stylization of existence was not self-love but an attempt to embody a moral and religious message. In a truly Augustinian style, Petrarch describes his old age in terms of conversion; growing old has made him turn away from his youthful, futile and earthly pleasures:

Adolescence misled me, youth swept me away, but old age set me right, and taught me by experience that truth I had read long before: that adolescence and pleasure are vain; or rather, it was the Creator of all ages and times who set me right. (XVIII, 1, p. 672)

Thus for Petrarch old age was a title, a privilege conferred upon his intellectual attainment and spiritual strength. The errors of youth are "best discovered by old age, which bares them for those who concealed them

${ }^{21}$ David Guttmann, "The Life Review: An Interpretation of Reminiscence in the Aged," Psychiatry 26 (1963), p. 67. 
or closed their eyes to them," Petrarch repeated in De Remediis utriusque fortunae's first allegorical dialogue, "Prime of Life" (I, 1, p. 15). ${ }^{22}$ His selfportraits in the Letters of Old Age have many similarities with De Remediis's debates on youth and old age; indeed, both works were written at about the same time. A Renaissance best-seller, De Remediis is a sum of medieval and classical wisdom aimed at helping human beings to negotiate the conflicts between reason and passion as they cope with the vicissitudes of Fortune in an unstable world. Book I presents remedies to the dangers of Fair Fortune (Prosperity); book II offers advice on how to face the blows of Foul Fortune (Adversity). In both books, allegorical characters discuss human dilemmas on a wide range of questions concerning life and death. Two pairs of "Passions"-Hope and Joy, Fear and Sorroware evoked by Fortune's emissaries, Prosperity and Adversity, and assault the human mind. Using eloquence, Reason takes on all of them at once, and with God's help, wins over her enemies. Reason and the four Passions are on stage throughout the two books, but Fortune and humankind are the real protagonists in the debates since the reader is required to exercise judgment, as a rational and virtuous being. In each dialogue, interpretation teaches self-knowledge, humility, patience, and trust in God. ${ }^{23}$

De Remediis's dialogues dealing with the ages of life elaborate on stereotyped attitudes, since Reason shows the reader how to come to terms with growing old, and how to behave accordingly. The genre of the debate reflects Petrarch's fondness for a rhetorical conception of human nature. In book I's first debate on "The Prime of Life," Reason addresses ways of coping with the body's decay. She warns Joy and Hope of the pitfalls of youth, "the most dangerous part of life" (I, 1, p. 13). The overconfident young man forgets that time is fleeting, and that old age is already upon him. How foolish it is not to prepare oneself for the winter of life. Reason suggests a standard Stoic exercise in this respect: from their youth on, Joy and Hope should already imagine themselves as wrinkled and old; most importantly, they should place their trust in eternal matters. The next debate between Joy and Reason on "The Body" elaborates on a similar commonplace: the contrast between the ephemerality of physical beauty and lasting spiritual qualities (I, 2, p. 16). Given the brevity of life,

22 Petrarch, De Remediis utriusque fortunae, trans. Conrad H. Rawski (Bloomington: Indiana University Press, 1991), 2 vols. All further quotations are from this edition and are incorporated into the text. The first number indicates the volume number, the second one the dialogue number.

23 Ibid., p. xxiv. 
one should capitalize on values that remain a source of joy and growth throughout life: faith in God, intellectual endeavors, honest pleasures, and virtue.

Both dialogues convey the importance of age in allocating roles since youth and old age are understood in terms of each other. Aged persons are figures of authority to be revered by youth. In other dialogues, however, the figure of the old person is far from exemplary. In book II's debate "On Old Age," Sorrow severely undermines Cicero's image of wise and serene old age by embodying negative commonplaces of the twilight years: she has a gloomy mood and a grumbling disposition. Sorrow keeps complaining about her wretched body. As she grows old she finds herself repulsive; the more she hates herself, the more she accelerates the decline of her physical and mental capacities. In her perspective, old age itself is dreadful and not the particular circumstances in which the elderly find themselves. Reason's lesson is straightforward in this respect: while it is true that certain inevitable effects of time must be reckoned with, human fulfillment depends on making the most of our allotted time in the face of death. The preparation for the afterlife is another important task of later life. Reason points out to Sorrow the universal aspect of the process of aging. Human beings are mortal, created by God from the dust and destined to return to it, as stressed in Saint Paul's epistles (Rom. 5: 12-14; 8). Yet Sorrow does not listen to Reason's advice to submit to the law of nature (II, 83, p. 196). She does not even hear Reason. She mourns her physical degradation, her illnesses, and the loss of dignity that comes with age; she laments the brevity of human life. Old age has reduced her self-esteem, and she looks at herself as a hostile stranger who has kept her ideal of youth. Reason replies that wisdom is sincere knowledge of God; the wise man goes willingly to death, whereas the wicked departs against his will. The losses that Sorrow mourns echo the words of Ecclesiastes (12:1-8), calling old age "the days of trouble... when you will say, 'I have no pleasure in them.' "

De Remediis's two books offer a treasure of meditations on a well-spent life. Throughout these debates there is a desire to mold people into idealized roles. Echoing classical, medieval, and biblical commonplaces, Reason reminds the reader that a life well lived bears riper fruit at old age, and that whatever aging may entail, no one will face it alone because God promises that "even to your old age I am here, even when you turn gray I will carry you" (Isaiah 46: 4). We often accuse the circumstances or Fortune of being responsible for our miseries, but in reality we ourselves make our lives wretched. As Reason points out, Sorrow's cause of affliction is within her, not in the biological process of aging. 
As Petrarch's dedication of De Remediis to Azzio da Correggio made clear, "those afflicted by false opinions must be healed by true maxims" (p. 10). De Remediis's commonplaces on age are not that far removed from Petrarch's self-portraits in the Letters of Old Age. These letters convey an image of old age as a state of mind and a voyage of self-discovery rather than an inevitable physiological condition. The metaphor of life as a journey is as old as thoughts on human existence; it can help us conceptualize Sorrow's and Petrarch's respective reactions to the passage of time. Sorrow looks at old age as the end of the journey of life; in contrast, in his Letters of Old Age (especially in the final letter to "Posterity") Petrarch represents his later years as a journey to life. Petrarch (and Cato the Elder in Cicero's De Senectute) praise old age as the culmination of the course of a well-led life. Sorrow, on the other hand, sees it as a diminution of life's fullness. The difference between these perspectives is not a question of fate (Fortune, good or bad, does not rule the world; only God does, Petrarch observed in his Letters of Old Age, Sen. VIII, 3) but of attitude. Man's best defense against the development of Sorrow's negative reaction to the flight of time is to acquire virtuous habits from youth onward. Following the model of Cicero's De Senectute and Seneca's Letters to Lucilius, the Letters of Old Age present the blooming of old age as the product of a life as a whole. The young man either develops "naturally" into a wise old man-such was Petrarch's own trajectory as portrayed in his Letters of Old Age-or decays into Sorrow's destructive and sterile melancholy.

\section{Castiglione}

In contrast to the moral and religious cast of Petrarch's self-portraits in the Letters of Old Age, Castiglione's presentation of the aged courtier in the Libro del Cortegiano offers an influential social and political model for later life. This model was again partly based upon classical sources that included Cicero's De Senectute. The fate of the old courtier in Castiglione's dialogue has been consistently overlooked, despite the fact that it reveals some major aspects of the author's views on court society. ${ }^{24}$

24 Teresa Ricci, “Old Age in Castiglione's Book of the Courtier," in Growing Old in Early Modern Europe. Cultural Representations, ed. Erin E. Campbell (Burlington, VT: Ashgate, 2006), pp. 57-73, gives a general description of the representation of the old courtier; Erin E. Campbell, "The Art of Aging Gracefully: The Elderly Artist as Courtier in Early Modern Art Theory and Criticism," Sixteenth Century Journal 33, 2 (2002), pp. 321-31, discusses 
The Libro del Cortegiano was a best seller in its time; first published in 1528, many French, Spanish, German, and English versions of the work circulated throughout sixteenth-century Christian Europe. ${ }^{25}$ The dialogue aimed at modeling an ideal courtier who knows how to behave with elegance and grace at court. The essential requirement was youth. The courtier must excel in sports, particularly the martial arts; in addition, a handsome appearance was de rigueur for the social entertainments of a court life in which women set the tone. A harmonious body reflected a superior mind. This combination of intellectual, moral, and aesthetic values drew heavily on the Neo-platonic ideals which underlie the book. The emphasis on physical perfection also had a practical aspect since centuries of wars on both sides of the Alps fostered a cult of virile athleticism. Throughout the book, individual identity is defined primarily through interrelationships. Age is therefore considered a predominant factor in social, political, and moral affairs: one's age permits access to certain experiences, denies access to others, and all told, embraces numerous implicit expectations. In addition, age plays a central role in the control and circulation of knowledge.

For the perfect courtier, to be old was hardly conceivable, since physical decline made it difficult to fulfill the demands of his station. In book II of the Cortegiano, Federico Fregoso, who embodies the ideal courtier's youth and beauty, cruelly mocks the old man who, despite his aging body, still dances in public and sends love letters to young women. Such a man, Federico argues, is so obviously blind to the image of himself as seen by others that he makes a fool of himself in public:

it is indeed unbecoming and most unsightly for a man of any station, who is old, gray, toothless and wrinkled, to be seen viola in hand, playing and singing in a company of ladies, even though he may do this tolerably well. And that is because the words used in singing are for the most part amorous, and in old men love is a ridiculous thing: although among other miracles, it sometimes seems that Love delights in kindling cold hearts regardless of years. (II, p. 77$)^{26}$

the relationships between the Book of the Courtier and Vasari's representation of the aging artist.

${ }^{25}$ See Peter Burke, The Fortunes of the Courtier (University Park: Pennsylvania State University, 1995).

26 Baldesar Castiglione, The Book of the Courtier, trans. C. Singleton, ed. D. Javitch (New York and London: Norton and Company, 2002). All subsequent references are to this edition and are incorporated into the text. The first number indicates the dialogue number. 
To avoid such unseemly displays, the elderly courtier is advised to desist from playing music and making love, as well as from pursuing games, arms, and dancing "before age obliges [him] to do so against [his] will" (II, p. 78). If an old man enjoys dancing and singing, let him do so, but let it be in private, Federico added. In this perspective, old age is in itself a deplorable condition. Signor Morello da Ortona, who, in contrast to Federico, is an old man, immediately objects to this characterization. Pretending to be angry, he replies: "And so it is better to rule out all old men, and to say that only young men are to be called courtiers!" (II, p. 78 ). In response, Federico observes that "every age brings with it its own cares, and has its own peculiar virtue and its own peculiar vice" (II, p. 78); he therefore criticizes old men who pretend to be young by dyeing their hair. The exchange ends with a burst of laughter among the ladies "for each of them understood that these words were aimed at signor Morello; and he seemed a little disconcerted by them" (II, p. 78).

Castiglione's protagonists define the courtier by his appearance and functional capacities rather than by chronological age. Focus on competitive physical excellence leaves little room for valorizing old age. Indeed, oppositions between youth and later life underlie the discussions of the protagonists in book II. These binary views convey an understanding of age that is divorced from individual experience as well as from the circumstances and context of this experience. By portraying the differences between "old" and "young" as extremes, such a representation assumes uniformity within these two stages of life. In Federico's discourse, the young courtier is entertaining, seductive, sociable, "spirited, generous, frank." The old one, on the other hand, is unattractive and impaired, socially dysfunctional and disengaged (II, p. 78). The latter's physical decline goes along with the deterioration of his social attitude: old men, Federico contends, are "more loquacious, miserly, difficult, and timid; are always ranting about the house, are harsh to their children, and insist that everyone should do things their way" (II, p. 78).

For centuries, these were the clichés of old age. They heavily relied on Aristotle's Rhetoric and Nicomachean Ethics - two books (along with Plato's Republic and Cicero's De Senectute, to which I shall return) that the courtier is advised to keep in mind as a reference. Older people, Aristotle added, continually praise themselves; they are shameless, and care more

I have also consulted the Italian version Il Libro del Cortegiano, ed. B. Maier (Turin: Unione Tipografico-Editrice Torinese, 1964). 
for profit than for honor. ${ }^{27}$ This bitter indictment of old age was especially popular in satirical literature and comedies; throughout the centuries, the misfortunes of the suspicious, lustful, and petty old man betrayed and fooled by youth have entertained generations of readers and spectators.

How could Castiglione possibly maintain such a negative perspective on old age? Obviously a courtier had no secret for staying young; moreover, he lived in an era when longevity among male members of his own class was on the rise, partly due to a higher infant survival rate, but also due to better hygiene and healthier eating habits. Castiglione was himself one of these aging men: he was fifty when his treatise was first published in 1528 , and many people who served as models for his characters were older. Pietro Bembo, for instance, was fifty-eight, and like many men of his generation who held key positions in the ecclesiastical hierarchy, he reached the highest offices late in life (he became a cardinal at age sixty-nine, in 1539). The Venetian republic (where the Book of the Courtier first appeared in print) provides another striking example of the political implications of age, since young and middle-aged citizens were not eligible for the most important public positions. ${ }^{28}$

It is tempting to read Castiglione's dedicatory letter of the Book of the Courtier to Don Michel de Silva, Bishop of Viseu as a nostalgic remembrance of the warm and witty court of Urbino in the early 1500 . In addition, Castiglione confesses that in reading these pages again, he was "seized by no little sadness (which greatly grew as [he] proceeded), when [he] remembered that the greater part of those persons who are introduced in the conversations were already dead" (p. 3). There follows a long list of names ending with a sad observation: the loss of "so many friends and lords... have left me in this life as in a desert full of woes" (p. 4). The author seems guilty of an error "which, as it is universally present in old people, can be thought to be proper and natural to them" - an error that his own persona condemns at the opening of book II: given the fact that the passing years have robbed him of many of the favorable conditions of life, he praises the past, and complains about the present (II, p. 65).

Despite the nostalgic tone of this dedication, however, the Book of the Courtier is not an elegiac celebration of a bygone era. ${ }^{29}$ The success of this

27 See Aristotle, Rhetoric II, 13, 1389b-1990a; Nicomachean Ethics, IV, 3, 1121, in The Complete Works of Aristotle, ed. J. Barnes (Princeton: Princeton University Press, 1984).

28 See chapter 1 , the section on Cornaro.

29 See Eduardo Saccone, introduction "The Portrait of the Courtier," in Baldesar Castiglione, The Book of the Courtier, pp. 328-41. 
work confirms that it responded to some needs specific to the context of its publication twenty years later. The author's own career illuminates some of these needs directly related to the portrait of the old courtier. When the Courtier appeared in print in 1528 , Castiglione was nuncio at the court of Emperor Charles V in Spain. In spite of the political and religious instability of the times, he still hoped to play a leading role in the emperor's and the pope's European politics. Rather than being a sign of selfish opportunism, this wish reflected his pessimism; after the sack of Rome in 1527 he had been (wrongly) accused by Alfonso de Valdès of not having prevented this tragic event. What we witness in the course of his revisions to his dialogue is a paradigm shift in the way the protagonists consider old age. Not surprisingly, this shift paralleled Castiglione's own experience as a courtier over the years.

In book II of the Courtier, Federico's negative portrait of the old courtier elaborates on representations from a bygone feudal image of the courtier as a skilled warrior in the service of his prince. Since youthful vigor was crucial to this scenario, old age signaled a time for withdrawal from the court. The Book of the Courtier was written over a twenty-year period; its various drafts gradually reduced the emphasis on arms and physical activities and placed diplomacy at the center of the relationships between the courtier and the prince. This was the perspective that was gaining momentum in internal and foreign affairs in the most powerful courts in Christian Europe, and Castiglione had a personal interest in this change. ${ }^{30}$ In the course of the dialogue, the career of the courtier moves from performance on the stage of the court to the sphere of political affairs. Alongside Federico's negative portrait of the old courtier, the second book points to commonplaces praising the old man to whom everyone turns for advice because he is "more prudent, more continent, and wiser than young men." The latter, in contrast, are "prone to quarrel, changeable, liking and disliking in the same instant, immersed in their own pleasures, and hostile to anyone who gives them good advice" (II, p. 78).

Prudence and wisdom are "acquired out of long experience," Federico notes in the second book of the Courtier (II, p. 79). The major sources of inspiration here are Plato's Republic, ${ }^{31}$ Cicero's De Senectute, and a treatise attributed to Plutarch: Whether an Old Man Should Engage in Public

\footnotetext{
30 See Amedeo Quondam, “Questo Povere Cortegiano." Castiglione, il libro, la storia (Rome: Bulzoni, 2000).

31 Plato, The Republic, trans. H. D. P. Lee (Penguin Classics: Harmondsworth Penguin, 1962), I, 1328a-b.
} 
Affairs. ${ }^{32}$ All three works are mentioned in Castiglione's treatise, and cast old men as figures of authority to be revered for their knowledge and sound judgment. Since physical and intellectual abilities peak and decline at different ages, old men should act accordingly, Federico adds. Rather than foolishly pretend to be young, they should capitalize on "the gravity of their years with a certain gentle and jocund humor."

In this way they will be good courtiers and will take much pleasure in the company of men and women, and, without singing or dancing, will be most welcome in such company at all times (II, p. 79).

This remark closes the discussion on the old courtier of the second book. The protagonists then turn their attention to other matters.

Yet the fate of the aging courtier presented a puzzling problem for Castiglione. Should old age be a time of withdrawal from public life? How could the courtier remain a key member of the court and keep the prince's confidence in spite of the physiological changes taking place in his body, and ultimately, because of them? These questions resurface in terms of continuity and adaptation by the end of the last book of the Cortegiano. Indeed, the issue was not of adding more or new qualities to this character as much as finalizing them. In the fourth book, signor Ottaviano praises the old courtier who gloriously ends his career as the prince's tutor or advisor (IV, pp. 239-41). In his work on Politics, Aristotle stated that the citizens of an ideal state should fulfill their duties according to their age, their physical strength, and their wisdom-that is, first as youthful warriors, then as experienced pedagogues and counselors to the head of the state. ${ }^{33}$ Cicero's De Senectute adopted a similar position (VI, 16-20), and so did Plutarch's treatise Whether an Old Man Should Engage in Public Affairs, which encouraged elder citizens to remain politically involved in their civic communities. ${ }^{34}$ In Castiglione's Book of the Courtier, such a view prevented potential tensions and intergenerational conflicts since it stressed obedience. The young courtier learns to act according to the ethical and political program outlined by the elder one; the old courtier, in turn, works in conjunction with the prince. From the outset, the young courtier knows that in due time he will be given the elder courtier's influential position and will have to gain the respect of every member of

\footnotetext{
32 Plutarch, Moralia, ed. and trans. H. N. Fowler (Loeb Classical Library: London, Harvard University Press, 1998), pp. $75^{-153}$.

33 Aristotle, Politics, II, 9, in The Complete Works of Aristotle.

34 Plutarch, Moralia, pp. 75-153.
} 
the court, including the prince. ${ }^{35}$ Warfare, sports, and tournaments are primarily youthful occupations; in contrast, the aged courtier has other assets than excelling in competitive games and in the battlefield, primarily his perceptive judgment.

In the second book, Federico had emphasized the wisdom of the aging courtier (II, p. 78); in the fourth book, Ottaviano elaborates on this notion by stating that the old courtier is instrumental in the transmission of power and knowledge from one generation to the next and should be responsible for the education of the prince. Speaking after Ottaviano, Bembo pushes this argument further by asserting that the courtier's political authority depends on retirement from the competitive arena of love. He thereby responds to Federico's earlier criticism of the indecorous behavior of the old man whose pursuit of love and beauty becomes the butt of satire. The importance of Bembo's speech is stressed by its length and by the fact that it is placed at the conclusion of the last book of the Courtier. Bembo's thesis can best be summed up in his own words: "the old can love without blame, and more happily than the young" (IV, p. 246). This viewpoint did not simply appeal to the tastes of an aging courtly male audience but was an effective means of maintaining a close relationship with the prince even in old age. Bembo's concluding portrait of the old courtier epitomizes the philosophical, social, aesthetic, and political ideals of Castiglione's work as a whole. It describes the courtier's transition to the most valued position in his circle: that of arbiter of the court, advisor to the prince, keeper of the court's traditions and values. This leadership partly depended on the social requirements of a milieu that favored rhetoric, and capitalized on the members of the court's intimacy and cultural homogeneity. Indeed, after a life-long practice of exchanges similar to those reported in Castiglione's work, the aged courtier knew how to influence his peers' and the prince's judgment while respecting their opinions. With dialogue comes persuasion, playfulness, and dissent; throughout the four books of the Cortegiano, the conversations between the protagonists convey different understandings of the questions under consideration; the aged courtier's familiarity with such dialectical games will help him maintain the group's harmony. As in daily conversations and courtly entertainments, he will take into account complementary and competing views. Such social and

35 The Duke of Urbino incidentally, "always retired to sleep very early after supper" (I, p. 12) the time the dialogues are supposed to have taken place. Nevertheless, the head of the court-the prince-remains one of the principal addressees of the Book of the Courtier. 
psychological skills are crucial for his political career, especially for his diplomatic missions of negotiation.

For Bembo, the aged courtier has less physical strength than in his youth but gains in influence because he is closer to the supernatural sources of power in the cosmos. The power and prestige of this character depend on his ability to reach - or, perhaps, to influence-God. Bembo defines love in Platonic terms, as "a certain desire to enjoy beauty" (IV, p. 243). Sexual desire may fool a young man, but not an old one who is no longer weighed down by his body and is guided by reason. Having climbed the ladder of love, the aged courtier's experience culminates in a contemplation in which spiritual beauty, the highest good, and the most holy love (the bond of the universe) coincide, bringing his life into a deeper union with God (IV, pp. 257-58). To indicate that his inspired utterance came from divine sources, Bembo invoked the god of love (like Socrates in the Symposium), and lost track of time during the revelation of these mysteries.

Many people are unable to reach the goal that Bembo described; moreover, only an exceptional man is capable of understanding that each step of the ladder of love leads up to the next one, and that the highest one epitomizes a transcendence of eros. Prefacing Bembo's speech, signor Morello, the elder member of the group, objected to what he considered an unrealistic perspective on love in later life. Bembo, he contended, wished old men to love in a way that he personally cannot understand: "it seems to me that to possess this beauty which he [Bembo] so much praises, without the body, is a fantasy" (IV, p. 247). This remark did not escape Montaigne's attention, as we shall see. ${ }^{36}$ As signor Morello noticed, nominal categories—be they "young" or "old" — do not map easily onto the experience of the individual.

\section{Montaigne}

Castiglione's dialogue offered an abstract perspective of old age that it did not consider either the courtier's decrepitude or his death. The view of the courtier's career as a continuous progress excluded the possibility of mental decline in later life. Bembo himself was quick to point out that the word "old" should not be taken "in the sense of decrepit or as meaning that the organs of the body have already become so weak that the soul

36 See chapter 3 , the section on Montaigne. 
cannot perform its operation through them, but as meaning when knowledge in us is in its true prime" (IV, p. 246). As such, Il Libro del Cortegiano responded to the wishes of aging gracefully of an increasing number of court members.

Over the course of the sixteenth century we witness a striking change in the ages of rulers. In 1519 the most powerful rulers in Christian Europe were in the prime of life. In France, Francis I was twenty-five; in England, Henry VIII was twenty-eight. The same year, Charles I of Spain was elected Emperor (under the name of Charles V) of the Roman Empire at age nineteen. Pope Leon $\mathrm{X}$ was in his forties, a relatively young age for such position since Renaissance pontiffs were on average aged fifty-four at the time of their election. The only exception was the eighty-two-yearold Doge of Venice, Leonardo Loredan. Venice remained a gerontocracy until 1797. A small number of young Venetians were allowed to participate in political debates to warm up the discussions, and some of them held minor public positions, yet these apparently liberal measures helped the elders to keep an eye on a few young ambitious patricians. ${ }^{37}$ The end of the sixteenth century offered a very different picture of the highest spheres of courtly life. Philip II of Spain and Elizabeth of England were well past the prime of life. In France, the Valois kings did not live long, but Catherine de Medici remained at the center of the political sphere for over a quarter of a century. In Italy as in France, old age held onto the reins of power in prescription and practice. Interestingly, Emperor Charles V's abdication at age fifty (in 1550) attracted a host of comments. Thirty years later, Montaigne still mentioned—approvingly—this event in his Essais (II, 8, p. 391/p. 343).

In the context of the French civil wars of Montaigne's time, discussions on the elders' advisory role were gaining momentum. Among French contemporary writers whose works Montaigne had read, Jean Bodin, Laurent Joubert, and Blaise de Monluc addressed the question of power and old age from different perspectives - political, medical, and military. A look at their pro-gerontocracy arguments in these fields will help to situate Montaigne's views on age and intergenerational relations within this broader intellectual context.

Jean Bodin drew his arguments in favor of gerontocracy from Plato's Laws and Republic, from history books, and works such as Cicero's De Senectute, Plutarch's Whether an Old Man Should Engage in Public Affairs

37 See chapter 1 , the section on Cornaro. 
(translated into French by Amyot in 1572), as well as from the Bible. The third book of Bodin's Six Livres de la République $(1576)^{38}$ accumulated historical and religious examples of old men's efficiency and wisdom in the political sphere. He noted that Solon forbade young men to participate in the Senate's decisions. Likewise, in Sparta, Lycurgus appointed a council of old men and this measure saved the city from anarchy as well as from the presence of dictators driven by the lust for power and self-interest. The Egyptians and the Persians also respected their elders, Bodin pointed out. The Scriptures offer similar views: God commanded the Hebrews to gather a senate of seventy old and wise God-fearing men (III, 1, p. 11/p. 255). Bodin argued that since councils of elders had been instrumental in a wide range of societies in the past, the same system in France would reinforce royal power and help reinstate peace. For Bodin, passions are dangerous, especially when it comes to making informed political decisions; they are common among inexperienced young men who lack the elders' moderation and self-control, as Plato had observed in Laws (664d, 740e). Yet age alone should not confer authority; only elders with a perceptive and sound judgment should be qualified to act as counselors. In addition, Bodin stressed loyalty, integrity, and justice as prerequisites for any role in the public sphere (III, 1, p. 12/p. 256). ${ }^{39}$

At the same time as Bodin, Laurent Joubert had different reasons to support gerontocracy. He was not in favor of a mandatory age of retirement for wise and efficient princes because he saw it as contributing to the social and political instability of the day. As a doctor, he reminded aging rulers of taking care of themselves:

A prince who takes care of his health lives longer, a most desirable thing in the eyes of his subjects. For the switching of a superior, under whom one has been nourished, to whom one has become accustomed and for whom one

38 Jean Bodin, La République, 6 vols., ed. C. Frémont, M.-D. Couzinet and H. Rochais (Paris: Fayard, 1986). The first reference is to the French edition (the numbers indicate respectively the book, the chapter, and the page; the second one refers to the page of the English translation, The Six Books of the Commonwealth. Facsimile reprint of the 1606 English translation, ed. K. D. McRae (Cambridge, Mass.: Harvard University Press, 1962). Further references are incorporated into the text.

39 Following Aristotle's Politics, Bodin also stressed the strong relationships between the republic and the family insofar as a republic is a gathering of families. The paterfamilias obviously older than his offspring - is the absolute master in his own realm; like the head of a state, his authority is incontrovertible because it is based upon nature. He rules over his wife, children, and servants until his death; more importantly, he teaches them the moral and religious values that are essential for the common welfare (I, 4, p. 20/p. 22). 
has developed affection and loyalty, is most unpleasant and most troublesome for subjects, especially since this change sometimes shakes, startles, and throws into disarray or bewilderment the condition of the nation or kingdom. We presuppose that the prince is an affable, legitimate ruler with the support of his people, subjects who would be very concerned if the good prince were not to live very long and rule over them for at least as long as a well man who took care of his health might be expected to live. ${ }^{40}$

Blaise de Monluc was also a proponent of old age's authority in yet another domain of public life, a sector usually associated with youthful vigor. Having left the battlefield at age seventy after a severe wound, he energetically advised the future Henri III to distance himself from his young "mignons" who had no military or political experience whatsoever. Stubbornly, the old Monluc kept telling the prince that young people-including Henri III himself-should listen to elders: "A young prince like you, from noble birth, the highest, and first in Christendom must always learn from old captains." A few pages later, he repeated that "youth must keep learning and must obey the elders." ${ }^{41}$ In spite of his powerful eloquence, Monluc did not obtain the military position he coveted. As his case made clear, the elder's authority was not taken for granted, hence its proponents' nagging persistence to reaffirm it. Indeed, the protestant Simon Goulart devoted a whole book to defending old age's leadership, wisdom, experience, and moral qualities. His Sage vieillard (1606) was read widely in France and in England (The Wise Old Man, 1621), ${ }^{42}$ but brought hardly any new arguments to the debate. Goulart "recycled" the same set of biblical and historical examples as Bodin, in a renewed attempt to solve a crisis that he saw mostly in moral and religious terms.

Yet how could the alleged wisdom of old age put an end to the turmoil of civil wars, Montaigne wondered. "Of Age" (Essais, I, 57) was a response and a challenge not only to Cicero's De Senectute but also to contemporary arguments in favor of gerontocracy and councils of elders. This chapter reflected the essayist's broader suspicion about abstract binary views

40 Joubert, Second Part of the Popular Errors, p. 257. On Joubert and the care of the self, see chapter 1 , the section on Montaigne.

41 Blaise de Monluc, Commentaires, ed., P. Courteault (Paris, Gallimard, 1964), pp. 801, 805, 807. "Un jeune prince comme vous et bien né, le plus grand et premier de la chrestienté, doit tousjours apprendre des vieux capitaines", "il faut que les jeunes demeurent apprentifs et obeissent aux vieux." My translation.

42 Simon Goulart, Le Sage vieillard décrit de divers autheurs (Lyon: A. de Harsy, 1606). The Wise Old Man (London: N. Bourne, 1621). 
(such as young-versus-old) and conceptual age categories. His discussion focused on historical examples and on his own experience.

Laws should take into account the nature of human existence, Montaigne observed in "Of Age." Instead of wasting their time on determining the legal onset of old age, the lawyers of the Roman Republic should have addressed the age a young Roman obtained his citizen's rights (I, 57, p. 327/p. 288). How ironic that Emperor Augustus postponed that threshold to age thirty, when he had conquered the world at about age twenty! What a waste of youthful energy and qualities! Men generally accomplish their most remarkable deeds when they are in their thirties; in addition to Augustus, the names of Alexander and Jesus immediately come to mind. For Montaigne, the old man is not qualified to take the reins of power because he belongs to a past world and has no other future than death.

Karl Mannheim's pioneering and influential socio-cultural study on "The Problem of Generations" in the 1920s provides a productive way to see the implications of Montaigne's position. Generation, as much as class, Mannheim claims, constitutes a formative factor for social groups; it links its members together not simply by their biological age, but also through shared experiences at a specific historical moment and exposures to particular aspects of cultural memory at a certain stage of their intellectual development and social integration. ${ }^{43}$ This is why, Mannheim observes,

While the older people may still be combating something in themselves or in the external world in such fashion that all their feelings and efforts and even their concepts and categories of thought are determined by that adversary, for the younger people this adversary may be simply non-existent: their primarily orientation is an entirely different one. (p. 299)

The conceptual and epistemological gap between older and younger people opens up moments of "fresh contact." On the one hand, youth's interaction with an inherited socio-cultural order "results in some loss of accumulated cultural possessions;" on the other hand,

it alone makes a fresh selection possible when it becomes necessary; it facilitates re-evaluation of our inventory and teaches us both to forget that which is no longer useful and to covet that which has yet to be won. (p. 294)

43 Karl Mannheim, "The Problem of Generations," in Essays on the Sociology of Knowledge, ed. P. Kecskemeti (London: Routledge and Kegan Paul Ltd, 1959), pp. 276-320; see especially p. 290. Further references are to this study and are incorporated into the text. 
Mannheim's conceptualization of the generational process retains room for difference as well. First, it acknowledges each generation to be a composite rather than a monolith, consisting of multiple differentiated units, split along nuanced socio-cultural and economic lines. Second, it posits the notion of a "generational site" or a "common location in the historical dimension of the social process."

... so that "the youth" experiencing the same concrete historical problem may be said to be part of the same actual generation, while those groups within the same actual generation ... work up the material of their common experience in different specific ways, [and] constitute separate generational units (p. 304).

Mannheim's basic assumptions remain unchallenged, at least in the case under consideration: the chapter "Of Age" in the Essais capitalizes on moments of "fresh contact." For Montaigne, the old man who confronts a new situation has a framework of useable past experiences so that, as Mannheim writes, "every new experience has its form and its place largely marked out for it in advance" (p. 296). Consequently the elder tends to keep repeating his previous experiences and is unable to evolve with the rest of the world; he is so used to the way things were that it might be difficult for him to go beyond his habitual thought patterns. The young man who does not have such a long past is more likely to adapt to a changing world and to consider new perspectives. In the twentieth century, Albert Einstein declared that we cannot solve problems through the same kind of thinking as when we created them. Montaigne similarly noted that as we age, yesterday's ways of reasoning form an invisible box out of which old persons resist venturing. Young people do not tackle questions the way their parents and grandparents did because they do not know these previous methods, and thus they are more likely to find new approaches. There is a certain fearlessness in ignorance that Montaigne admires, although paradoxically it is obvious to the reader that Montaigne's own case is an exception to the rule: the essayist's aging brain and vast erudition give him great insights into creativity and innovation.

Nevertheless, "All things have their season," he contended in another chapter ("Toutes choses ont leur saison," II, 28, p. 702/p. 644). As Montaigne grew old, he claimed to be "fall[ing] far from [his] early vigor and cheerfulness, and beginning to grow withered and rancid." He added: "I am at the bottom of the barrel, which begins to taste of the lees." "descheu de ma premiere vigueur et allegresse, tirant sur le flestry et le rance. Je suis sur le fond du vaisseau, qui sent tantost le bas et la lye" (II, 37 p. 784/p. 
724). Still, he was fully aware that there are no definitive judgments on anything (especially the self), because there are no objective criteria for evaluating things but only discrepancies between the many ways things appear to us. In contrast to Cicero's unconditional praise of Cato the Elder's sound judgment in De Senectute, Montaigne was convinced that an individual does not necessarily become wiser as years go by. He thought that in certain ways he had the same amount of wisdom in the prime of his life as in his fifties, although the "quality" of his wisdom was different according to his age (III, 2, p. 816/p. 752). ${ }^{44}$ In addition, what exactly is the nature of the alleged wisdom of old age? He noted that the acquisition of such quality is often the result of external circumstances and coincidences rather than a matter of accrued experience. In Job's words, "It is not only the old who are wise, not only the aged who understand what is right" (Job 32: 19). Montaigne even believed that to some extent, Socrates had lent himself to his condemnation to death, "being seventy, and having so soon to suffer an increasing torpor of the rich activity of his mind, and the dimming of its accustomed brightness" "ayant de si pres, aagé de soixante et dix ans, à souffrir l'engourdissement des riches allures de son esprit et l'esblouissement de sa clairté accoustumée," III, 2, p. 817/pp. 752-53).

He was not the first Renaissance writer to criticize gerontocracy. In his Discourses (a work Montaigne certainly knew), Machiavelli praised the Romans of the early Republic who judged the candidates for political positions on their skills rather than on their age. ${ }^{45}$ His remark targeted his fellow Florentine citizens who did not consider a man under the age of twenty-nine for any key public function. In Art of War, Machiavelli went one step further, and accused the old Florentines of being responsible of the city's humiliation because of their conservatism and passive resignation. ${ }^{46}$ Guicciardini, Varchi, and Vettori, who were also in favor of the giovani, similarly saw old rulers as an obstacle to political liberty and democracy. ${ }^{47}$

\footnotetext{
44 "ma sagesse peut bien estre de mesme taille en l'un et l'autre temps [en ma jeunesse et en ma vieillesse]; mais elle estoit bien de plus d'exploit et de meilleure grace, verte, gaye, naïve, qu'elle n'est à present: croupie, grondeuse, laborieuse" (III, 2, p. 816).

45 Niccolò Machiavelli, Discorsi sopra la prima Deca di Tito Livio (libri III). Dell'Arte della guerra. Dalle Legazioni, ed. R. Rinaldi (Turin: UTET, 2006), p. 10.

46 Machiavelli, The Art of War, trans. C. Lynch (Chicago: Chicago University Press, 2003), pp. 37-42.

47 Richard Trexler, Public Life in Renaissance Florence (New York: Academic Press, 1980), pp. 396, 510. John M. Najemy, A History of Florence, 1200-1575 (Malden, Mass.: Blackwell, 2006), pp. 375-413.
} 
Young men represent the future and should take the leadership because they bring social rejuvenation; old men should withdraw from public affairs, such was the essayist's contention in "Of Age." Yet did his personal career really correspond to such views? Montaigne retired in 1571, at age thirty-eight; he thought that he had lived the major part of his life and that death was approaching. His decision did not prevent him from serving as the mayor of Bordeaux for two terms in a row some years later. Indeed, his retreat was a way to maintain a balance between his professional obligations and his attempt to know himself. As he wrote in the chapter "De Mesnager sa volonté" (III, 10, pp. 1004-5/ "Of Husbanding your will," pp. 932-33), he fulfilled his professional duties as best he could, but always saw them as a temporary performance on the stage of the world.

Political action can take many forms. As Plutarch (one of Montaigne's favorite authors) contended at the end of his treatise Whether an Old Man Should Engage in Public Affairs, ${ }^{48}$ an old man can give his fellow citizens sound and frank advice without being appointed as the prince's counselor or advisor. To what extent did Montaigne's restless efforts to promote his Essais at the court (he went to Paris to offer his work's first edition to Henri III in 1580) correspond to Plutarch's remark? In contrast to Cato the Elder in De Senectute, he never claimed to be a role model for his readers; yet in a time of civil wars and fanaticism, his work opened up insightful ways to question prejudices and to fight intolerance by exercising one's judgment on a variety of topics. ${ }^{49}$

No age of life stands alone; "generations are in a state of constant interaction," Mannheim noted (p. 301). Montaigne saw this relationship in terms of cooperation rather than of power and authority; the elder teaches the young person, and vice-versa. ${ }^{50}$ As he grew old, he claimed to be more receptive to younger people's ideas. Was his elasticity of mind and his openness to new ideas the result of a lifelong experience? In certain spheres, a man may achieve a greater adaptability in his later years than in his youth because he is in a better position to distance himself from his "original approach," Mannheim observed (p. 302).

Nowhere is the link between generational tensions and social practices stronger than in matters of inheritance of wealth and estates. Countless

\footnotetext{
48 Plutarch, Moralia. pp. $75^{-153 .}$

49 See Géralde Nakam, Les 'Essais' de Montaigne, miroir et procès de leur temps. Témoignage historique et création littéraire (Paris: Champion, 2001).

50 His considerations on education strike a similar note, and emphasize the bond between the child and his tutor $(I, 26)$.
} 
authors (from Plautus, Terence to Molière on) have elaborated on the conflicts between almighty fathers and powerless children in humorous, tragic, pathetic ways. Likewise, Montaigne's chapter "De l'affection des pères aux enfans" (II, 8, "Of the affection of fathers for their children") includes contemporary stories of despotic fathers who refused to hand properties over to their sons and daughters, resulting in desperate acts. For Montaigne, the lesson is clear: the abusive paterfamilias brings destruction on his relatives and destroys himself as well; only mutual affection, dialogue, and respect among members of different generations are fruitful. Consequently, old men should delegate the ordering of their estates to their children, who can cope much better with such weighty matters. Obviously, such a view applied only to upper-class, wealthy families. In Montaigne's case, the problem of inheritance was complicated by the fact that without a son he was the last male of his lineage. He had a young daughter, and told his readers that he would gladly have left the management of his estate to his future son-in-law, passing on to him such daily worries (III, 9, p. 953/p. 882). Despite his liberality and lack of interest in practical matters, he did not squander his inheritance, and even increased it with a non-transferable honorific title of "Citizen of Ancient Rome," he ironically noted in "Of Vanity" (III, 9, pp. 999-1000/pp. 930-31).

Here and elsewhere, his comments stemmed from his personal experience and from his dialogue with books. The last additions to the Essais indicate that he was rereading De Senectute in his later years; indeed, some of his self-portraits capitalized ironically on the stereotypical weaknesses of old age catalogued by Cato the Elder. Cicero's protagonist was a dynamic old man who never wasted an instant, whereas Montaigne claimed to devote himself to the delights of idleness. In reality, his alleged leisure produced the Essais, which obviously required a great deal of work, but he was one of those people for whom old age and retirement meant the possibility of fulfilling a hitherto suppressed literary vocation. An exemplary character in every respect, the octogenarian Cato the Elder denied his physical and intellectual decline; in contrast, Montaigne exaggerated the negative impact of age on his body and his mind: from his thirties on, he was certain that "since that age [his] mind and [his] body ha[d] rather shrunk than grown, and gone backward rather than forward." (I, 57, p. 327/p. 289). Each of Cato's activities had a rational explanation and a clear purpose in De Senectute: he increased the value of his property by cultivating his land, read books to learn from them, discussed with young men to pass on his lifelong experience to the next generations. Montaigne shared some of these interests, but claimed that he did not 
pursue any specific goal and that he was unable to focus his attention for a long time on anything. He glanced over books without reading them systematically, and considered them as an entertaining pastime rather than as a source of knowledge. Spending later life's leisure in bookish studies, as Cato the Elder did, seemed to him nonsensical. Such claims served to justify the informal essay genre. ${ }^{51}$

\section{Conclusion}

Each of the writers discussed in this chapter adapted classical sourcesincluding Cicero's Cato Maior De Senectute - to different historical circumstances. Methods of appropriation range from direct references to previous texts, to combinations of different models, and subversion of their meaning. My discussion has focused on these aged writers' responses to the turmoil of the day: whether they favored gerontocracy, councils of elders, or social rejuvenation, Petrarch, Castiglione, and Montaigne and his contemporaries strove for peace and political harmony. Their works built communities of readers by offering ways to think about the political and social tensions of the day in terms of intergenerational dialogue.

Competition, authority, withdrawal, and subordination are only a few of power's modes of expression when dealing with intergenerational relations. On the one hand, the respect due to the elder became a justification of social continuity in works as different as Petrarch's Letters of Old Age, Castiglione's Book of the Courtier, Bodin's political treatise Les Six livres de la République, Joubert's medical observations in Les Erreurs populaires, and Monluc's memoirs of a soldier. On the other hand, the defense of gerontocracy, councils of elders, and more broadly speaking, of stereotypes of age came under scrutiny. Writers such as Montaigne unmasked their inconsistencies and questioned their binary views of old-versus-young.

Interestingly, the old-versus-young confrontation has recently become a renewed focus of attention insofar as from the late 1980s on, increases in retirement age in the Western world have reversed a century-long trend towards earlier retirement. A Gallup poll released on April 2010 notes that "Americans' projected retirement age continues to creep up."52 People are

51 See also chapter 4 , section 3 on this point.

52 http://www.gallup.com/poll/127514/Americans-Projected-Retirement-AgeContinues-Creep-Up.aspx?utm_source $=$ tagrss\&utm_medium $=$ rss\&utm_campaign $=$ syndication\&utm_term=All\%2oGallup\%2oHeadlines. 
holding onto their jobs, and "older workers are replacing younger workers in the labor force." ${ }^{53}$ The current change in the age composition of the working population depends mostly on the uncertainty about our own future economic environment, ${ }^{54}$ yet the growth in the employment of individuals over age sixty-five may also be responding to broadermore philosophical and sociological-reasons, including the prospect of longer life spans or matters related to an individual's well-being and lifestyle. Some could argue, for instance, that in ideal conditions, working longer might help elders from the middle class stay intellectually alert and actively involved in their community. Others, on the other hand, may stress the psychological benefits of an early retirement such as peace of mind or more time allotted for leisure and family activities.

Petrarch and Montaigne, for their part, explored the relations between aging and self-knowledge. The aged Petrarch saw himself as different from his previous, youthful persona, and claimed to have a better understanding of his condition. His later life was a time of literary and personal cohesion; he completed unfinished texts and recollected the fragments of his own past. In a letter written to Boccaccio in 1373, a year before his death, Petrarch noted, "I am aroused, however late, to correct with God's favor what was missing not only from my life, but also from my writings" (Sen. XVII, 2, p. 647). ${ }^{55}$ In yet another epistle of his Letters of Old Age, he stressed his ability to cope with the blows of fortune, and gratefully acknowledged the weakening of his youthful lust. He then thanked old age, God, and books for granting him peace of mind (Sen. VIII, 2, p. 275/Lettres, vol. 3, p. 57). For Petrarch, youth was a gift of nature, but old age was a work of art. Montaigne, for his part, represented his experience of growing old in a less straightforward and more complex manner. He watched himself grow old "by pieces" rather than follow an ascending path from youth to old age. Decline and growth go hand in hand throughout the life course, he observes in the chapter "Of Experience": "le declin praeoccupe son heure et s'ingere au cours de nostre avancement mesme"

53 Read On ABC News Radio: http://abcnewsradioonline.com/business-news/young-peoplestruggle-to-find-jobs-while-elders-hold-on-long.html\#ixzz26CewVYC 3 , Accessed March 14, 2013 .

54 In the United States, the long-term viability of Social Security, potential benefit reductions, the health care and long-term costs play a major role in decisions to delay retirement.

55 "expergiscor, ut favente deo emendem-vero licet-in me, non solum quod vite defuerit, sed etiam scripture." On the same topic, see also Sen. XII, 1, p. 439/ Lettres, vol. 4 , pp. $15^{-17}$. 
(III, 13, p. 1102/ "Decline mingles and fuses with our life throughout," p. 1031). Since improvements and weaknesses are inseparable, he capitalized on the stereotyped negative effects of aging that fitted the informal genre of the essay. This process reinforced his feeling of the polyphony of the self. ${ }^{56}$

For Montaigne as for Petrarch, growing old brought an awareness of otherness. Their respective comments on love in old age were an important part of this perception, as we shall see in the next chapter.

56 See chapter 4, section 3 . 


\section{LOVE IN OLD AGE}

The previous chapters have examined personal experiences of later life in two distinct yet related fields - the elder's daily health care and his public role. In both areas, the focus was on the aging body and on different forms of self-government that shaped the expression of individual identity and permeated political thinking. Yet to what extent do we believe that we are old? How do we know that we are old? As long as the subjective feeling of youth remains alive, the "objective" evidence of age seems fallacious. "The tragedy of old age is not that one is old, but that one is young," Oscar Wilde ruefully noted. We are always the same age "inside," although a wrinkled face and an aged body legitimate some social behaviors, while excluding others. As Simone de Beauvoir wrote, "Within me it is the Other-that is the person I am for the outsider-who is old, and that Other is myself." Without the tension between these different perceptions, it is difficult to understand how we come to realize that we are growing old, for it is in relation to broader social norms of aging that we can make sense of the effects of the passing of time on our body and mind.

Renaissance self-portraits of old men in love offer a fruitful way to examine the cultural implications of this question. At stake is nothing less than the relevance of the traditional division of the life cycle into ages. ${ }^{2}$ In spite of their endless variations, literary representations of aged lovers revolve around a remarkably stable set of stereotypes. For centuries, Western philosophers, writers, and moralists have stressed the weaknesses, moral and physical, to which the ages of life are prone when it comes to experiencing love. On the one hand, they have scorned youth's concupiscence and uncontrollable passion; on the other hand, they have mocked the lustful old man and the aged misanthrope. Others have argued that as the years go by, a young man's attraction to love's sensual pleasures is balanced by emotional growth that culminates in the wisdom traditionally granted to

1 Simone de Beauvoir, The Coming of Age, trans. P. O’Brian (New York: Putnam's Sons, 1972), p. 284 .

2 The mechanisms influencing the perception of a person's age in a specific milieu are beyond the scope of this study. 
the winter of life. These generalizations have enabled individuals to monitor their conduct and to shape themselves according to such "codes."

In The Use of Pleasure, Foucault examines why sexual behavior, and the activities and pleasures which are dependent on it are made the object of moral concern. ${ }^{3}$ He sees this "problematization" in the Greco-Roman culture as one of the earliest aspects of a general history of "techniques of the self." His study of Greek and Latin prescriptive texts (the aphrodisia) from the fourth century $\mathrm{BC}$ and the first two centuries $\mathrm{AD}$ shows that sexual ethics was then part of a wider discussion of the proper use of pleasure and therefore linked to the question of self-mastery. Pleasures tending toward excess were said to lead to a form of enslavement; in contrast, a life of moderation (of power over one's pleasures) and self-mastery opened up a condition of individual freedom. Early Christian texts appropriated some of these views, such as the exaltation of continence, ${ }^{4}$ yet this exaltation does not have the same value in each culture. The Christian requirements of sexual austerity, for instance, became more coherent and authoritarian than in ancient philosophy; these requirements were subsequently "integrated with Christianity into the exercise of pastoral power, then later into educative, medical, or psychological practices." 5

Commenting on his investigation of the constitution of the self as a "subject of desire" in Greek and Roman Antiquity, and in early Christianity, Foucault notes in the preface of The Use of Pleasure:

It was a matter of seeing how an "experience" came to be constituted in modern Western societies, an experience that caused individuals to recognize themselves as subjects of a "sexuality", which was accessible to very diverse fields of knowledge and linked to a system of rules and constraints. What I planned, therefore, was a history of the experience of sexuality, where experience is understood as the correlation between fields of knowledge, types of normativity, and forms of subjectivity in a particular culture. (p. 4)

By "experience," Foucault means the "correlation of a domain of knowledge, a type of normativity, and a mode of relation to the self." ${ }^{6}$ The Use of Pleasure discusses relations between boys and mature men in Antiquity, but never addresses the question of love in old age. Such perspective,

\footnotetext{
3 Foucault, The Use of Pleasure, pp. 23-24.

4 Ibid. pp. 20-21.

5 The Foucault Reader, ed. Paul Rabinow (New York: Pantheon, 1984), p. 17.

6 The Foucault Reader, p. 333. See also Foucault, The Use of Pleasure, pp. 4-5.
} 
however, reveals an aspect of sexuality closely related to a system of social prohibitions and ethical values.

My focus will be on forms of relationship to self, on the practices through which one constitutes oneself as an object to be known, and on ways of speaking about love in old age. This chapter is about aged writers who acknowledge themselves as subject to desire while questioning the binary old-versus-young views. By finding new ways to articulate such commonplaces, their self-portraits had the capacity to disrupt these dichotomies and the "systems of thought" within which they worked. Petrarch addressed these questions within a Christian framework; with the graying of the courts and salons of the sixteenth century, however, the posture of the aged lover led Ronsard, Montaigne, and Pasquier to raise issues concerning social behavior, and to challenge the assumptions of the alternative between the lustful or the chaste old man. All four authors introduced nuance and leeway into rigid habits of thought epitomized by age stereotypes, and represented themselves as both old and young at the same time.

The authors in question do not offer faithful accounts of lived experiences; rather they are acute and astute readers of their own earlier texts. The emphasis will therefore be on their respective attitudes toward their vocation as writers, rather than on their eventual (and undocumented) psychological development.

\section{Petrarch}

Petrarch's writings have often been regarded as a manifestation of a new awareness of the flux of time, and with it of a new conception of subjectivity, ${ }^{7}$ yet critics have refrained from examining the moral and psychological effects of time on the poet's persona. I will be elaborating on previous findings to complement these contributions by looking at the impact of time on the writer's self-portraits as an aged lover in the Rime Sparse (or Rerum Vulgarium Fragmenta as Petrarch used to call this collection) and the Secretum.

Petrarch used to call his collection of love poems to Laura "little trifles" (nugellas) and his decision to write in the vernacular indicated that he did not put these at the same level as his most ambitious Latin productions.

7 Gurk Zak, Petrarch's Humanism and the Care of the Self (Cambridge: University Press, 2010), pp. 7-22 provides a good review of these comments. 
Yet, he kept putting together these scattered "fragments" up to his death, and had a lavish copy of the collection made.

From the poet-lover's confession of his "error" in the first poem of the Rime Sparse to his final prayer to the Virgin, conversion-involving death of a former self and spiritual rebirth-underlines the design of the collection as a whole:

Voi ch'ascoltate in rime sparse il suono

di quei sospiri ond'io nudriva 'l core

in sul mio primo giovenile errore, quand'era in parte altr'uom da quel ch'i' sono... spero trovar pietà, non che perdono.

You who hear in scattered rhymes the sound of those sighs with which I nourished my heart during my first youthful error, when I was in part another man from what I am now... I hope to find pity, not only pardon $(R$ 1, ll. 1-4, 8). 8

This experience introduces a radical discontinuity between the aged poet's devotion to God on the one hand, and his youthful and sinful passion for a woman, on the other hand. The distance of oneself from oneself is what becomes evident. This aspect deserves a closer look: rather than acknowledge his conversion to God in his later years, the poet describes a conversion of the "modality" of his gaze. As he grows old, his way of seeing love and himself has changed; yet, although he is aware of his spiritual derailment and repents, he is still "partly the same man." Laura is still the focus of his life, and the memory of his beloved keeps turning him away from the love for God. Throughout the Rime, anniversary poems commemorate the time that has elapsed since he saw Laura. According to this chronology, the poet was twenty-three years old when he first caught sight of a young married woman in the church of Saint Clare in Avignon on April 6, 1327, and fell in love - a love that would last the rest of his life. He was aged forty-four when his lady died from the Black Death on April 6, 1348. Sixteen years after his first encounter, his desire remained as intense $(R 118)$; seventeen years later, and even twenty and twenty-one years later, he is still obsessed with her $(R 122, R 212, R 271, R 364)$.

In Sonnet 145, he acknowledges that regardless of where he is, or what happens to him, he remains the same: "still I shall be what I have been,

8 Petrarch, Lyric Poems. The Rime Sparse and Other Lyrics, ed. and transl. Robert M. Durling. (Cambridge, Mass.: Harvard University Press, 1976). All further quotations and translations are from this edition and are incorporated into the text. " $R$ " refers to "Rime". The first number refers to the poem number, the second one to the line number. 
shall live as I have lived, continuing my trilustral sighing" ("sarờ qual fui, vivrờ com'io son visso,/ continuando il mio sospir trilustre" ( $R$ 145, 1l. 13-14)). The collection tells of the circular nature of his desire and writing: "and new tears for old desires show me to be still what I used to be, not for a thousand turnings about have I yet moved” (“... et d'antichi desir lagrime nove/ provan com'io son pur quel ch'i' mi soglio,/ né per mille rivolte ancor son mosso" $R$ 118, 1l. 12-14). ${ }^{9}$ The cycle contains 366 poemsequal to the days in a calendar year, plus one day-but the new year epitomized by this additional day does not bring the poet a new life:

In questa passa 'l tempo, et ne lo specchio

mi veggio andar ver la stagion contraria

a sua impromessa et a la mia speranza.

Or sia che po: già sol io non invecchio,

già per etate il mio desir non varia ... $(R$ 168, ll. 9-13)

In the meanwhile time passes, and in the mirror I see myself nearing the season that is contrary to his promise and to my hope. Now come what will: I am not the only one who is growing old, and my desire does not vary at all with age...

His experience confirms the truth of a proverb he mentions in yet another poem: “one's hair will change before one's habits and human passions are no less intense because of the slackening of sense" $\left(R 122,11.5^{-7}\right) .^{10}$ The posture of the lover growing old is a traditional comic character, but the poet eliminates any such incongruity because he is his own judge. His lucidity recalls Petrarch's observation in his Letters of Old Age: "My very age and-unless I am mistaken - my even temper make me one of the fit judges. I know what I am." (Sen. VIII, 2, p. 274/ Lettres, vol. 3, p. 45).

Writing changes his self-perception because it puts Petrarch in front of other people's eyes: the poet feels that he is being watched; what was confused and subjective now becomes objective. Rather than making him a laughing stock, his painful self-awareness of the incongruity of his feeling puts his "error" in a Christian and moral perspective. At the same time, however, the compulsory confession of his sinful love becomes a pretext for endlessly telling every psychological nuance of the story of his spiritual derailment.

\footnotetext{
9 See Zak, Petrarch's Humanism and the Care of the Self, pp. 27, 45.

10 "Vero è 'l proverbio ch'altri cangia il pelo/ anzi che 'l vezzo, et per lentar i sensi/gli umani affetti non sono meno intensi..." $\left(R\right.$ 122, ll. $\left.5^{-7}\right)$.
} 
In contrast to the Rime's wide circulation, the text that most clearly illuminates this process of self-examination and the protagonist's failure to convert is the Secretum (written in about 1547), which had a much more private diffusion. ${ }^{11}$ The Secretum is a fictitious dialogue between Franciscus (Petrarch) and Augustinus (Saint Augustine) in the symbolic form of a dream. Throughout their conversations, Augustinus- "a wise old man of venerable and majestic appearance" (p. 4) - epitomizes the aging Franciscus's consciousness, and probes his interlocutor in an attempt to ease his inner conflicts. Truth (reminiscent of Boethius's allegorical Philosophy) silently witnesses the exchanges. The work contains three books, dealing with the relations between will and desire (book I), the seven deadly sins (book II), and literary immortality and love (book III). Throughout these dialogues, references to Virgil, Cicero, and Seneca provide the foundations of a discussion that articulates alternative ways of life. Augustinus makes clear that Franciscus does not wish wholeheartedly to reform his life and be freed from earthly passions, hence the latter's unhappiness.

Book III focuses on Franciscus's confusion when it comes to love and ambition. Augustinus first takes up Franciscus's lifelong passion for Laura, and points out some early physical signs of his interlocutor's aging:

Have you seen yourself in a mirror recently?... Have you noticed how your face changes from day to day, and how some white hairs have already begun to appear on your head?... Has the sight of your changing body made any change at all in your mind?... White hair is a sign of approaching old age and a warning of death. (Secr. III, pp. 77-78)

Seemingly unaware of the brevity of human life, Franciscus replies by mentioning a number of famous men who serenely accepted the graying of their temples at an early age. He fails to understand that death is already upon him; indeed, his reading of signs is superficial. For Augustinus on the other hand, growing old means ordering one's desires (as Seneca observed in Ad Lucil. 20, 5) and dedicating oneself to enduring, spiritual values. The saint says to his interlocutor, "be ashamed to be called an

11 Petrarch, Secretum, ed. Enrico Carrara, in Petrarch, Prose, ed. Guido Martellotti, P. G. Ricci, et al. (Milan and Naples: Ricciardi, 1955), pp. 21-215. I have also consulted Il mio Segreto, ed. Ugo Dotti (Milan: Rizzoli, 200o). All English quotations refer to My Secret Book, transl. J. G. Nichols (London: Hesperus, 2002) and are incorporated into the text. The first number indicates the book number, the first page number refers to the English edition. When needed, I have added a second page number indicating the Latin edition. I have also consulted Carol E. Quillen's translation, The Secret (New York: St Martin's Press, 2003). 
elderly lover. Be ashamed that for so long you have been the talk of the town" (Secr. III, p. 80)..$^{12}$ His remark directly echoes the Rime's first sonnet $(R$ 1, ll. 9-11). Augustinus's argument remains the classical one of attaining self-mastery over the passions. The pursuit of self-control and virtue in this life helps secure an individual's place in the next. Only by rejecting earthly distractions and false pleasures will Franciscus find true happiness in God. Echoing the inner struggles of Laura's lover in the Rime sparse, Augustinus keeps urging Franciscus: "You should [...] be ashamed that your state of mind has not changed while your body has been continually changing" (III, p. 81). ${ }^{13}$

In the Rime, the lack of chronological organization of the poet-lover's narrative reflects his spiritual confusion. Rather than offering a coherent story of his passion, he juxtaposes fragments of different moments of his life. Like the aged poet of the Rime, Franciscus recognizes that he is responsible for his own destruction, yet he clings to it. He exhibits the stereotypical difficulty of old people in changing their longtime habits and behaviors. After three days of conversation with Augustinus, Franciscus is still moving in the wrong direction, and the end of the last dialogue lacks decisive closure. Augustinus asks God to help his interlocutor "reach safety," and Franciscus hopes that "the storm in [his] mind will die down [...], and Fortune stop troubling [him]" (III, p. 93). For the reader, the lesson is straightforward: Franciscus is to watch over himself-his behavior, his thoughts, and his soul. The dialogue points out human beings' freedom of choice, while also stressing that whoever wishes to discard his unhappiness has to devote himself to God (I, p. 7). ${ }^{14}$ In spite of Augustinus's efforts, however, Franciscus echoes the poet-lover of the Rime, and acknowledges that "the root of [his] unhappiness is in [his] will." (I, p. 11).

Both texts champion a conception of love capitalizing on caritas. Both of them urge the poet to find joy in God, and to avoid earthly pleasure that cause the soul's distraction, dispersion, and dissipation. For Laura's lover in the Rime, as well as for Franciscus, old age brings a particular poignancy to the concern for death and the afterlife. Along with this spiritual

12 "Pudeat ergo senem amatorem dici; pudeat esse tam diu vulgi fabula" (Secr. III, p. 65).

${ }_{13}$ On this passage, see Zak, Petrarch's Humanism and the Care of the Self, pp. $5^{2-58}$.

14 On the lack of any reference to Grace, see Carol E. Quillen, Rereading the Renaissance. Petrarch, Augustine, and the Language of Humanism (Ann Arbor: University of Michigan, 1998), pp. 182-216. 
growth, the portrait of the writer in the winter of his life conveys a sense of self-awareness.

\section{Ronsard}

In the Rime, old age brought the poet a feeling of loss, dependency, loneliness, and depression. Approximately two centuries later, Pierre de Ronsard ironically commented on Petrarch's self-portrait as a transfixed and weeping lover, deliberately blurring the distinction between the Tuscan author and his poetic persona. In Ronsard's view, anyone with common sense would find the Rime's story of endlessly frustrated love and inner struggles quite insane:

Ou bien il [Pétrarque] jouyssoit de sa Laurette, ou bien

Il estoit un grand fat d'aimer sans avoir rien.

Ce que je ne puis croire, aussi n'est-il croyable:

Non, il en jouyssoit: puis la fist admirable,

Chaste, divine, saincte... (I, pp. 168-69) ${ }^{15}$

Either he (Petrarch) had sex with his little Laura, or he was a big fool to love without having anything, which I cannot believe; indeed, it is unbelievable. No, he had sex with her; then he made her admirable, chaste, divine, saintly....

Surely, Petrarch "committed no such sin, remaining in love with his lady for thirty-one years, without any other ever being able to warm his soul," Ronsard adds ironically (I, p. 168). ${ }^{16}$ His blatant distortion of Petrarch's moral and Christian framework was a way to set himself up as the champion of inconstancy. In a time of renewed interest in Petrarch and Petrarchan poetry with a Neo-Platonist flavor in French aristocratic salons, Ronsard managed to sound out new resonances from Petrarch's Canzoniere. While competing with the young Philippe Desportes's verses of Amours de Diane and Amours d'Hippolyte (published in his Oeuvres, 1573), Ronsard's Sonnets pour Hélène (1578) reflected the complex situation of an aged poet adopting the posture of a lover. In book II of Castiglione's influential

15 Pierre de Ronsard, CEuvres, ed. Jean Céard, Daniel Menager, and Michel Simonin (Paris: Gallimard, 1993) vol. 1, pp. 168-69. All further references are to this edition and are incorporated into the text. All translations of Ronsard's poems are my own.

16 "le bon Petrarque un tel peché ne fist/ Qui fut trente et un an amoureux de sa dame, / Sans qu'un autre jamais luy peust eschauffer l'ame". On this point, see Sara Sturm-Maddox, Ronsard, Petrarch, and the "Amours" (Gainesville: University Press of Florida, 1999), pp. 84-89. 
Libro del Cortegiano, the young Federico Fregoso cruelly mocked the old man writing love letters to young girls (II, p. 77). ${ }^{17}$ Yet such was the situation of a growing number of aging French poets in the second half of the sixteenth century-including Ronsard himself. Many of them were probably not really in love; nevertheless, they were expected to write love songs in spite of their lined faces.

For Georges Minois, Ronsard's poetry epitomizes the Renaissance general cult of youth, and contempt for old age. ${ }^{18}$ His thesis does not take into account Ronsard's multiple perspectives on age and his tendency to elaborate on a wide variety of texts and commonplaces on Time's flight. ${ }^{19}$ Interestingly, the word "vieillesse" (old age) and its derivatives appear more than six hundred times throughout Ronsard's work, whereas words related to "young" and "youth" ("jeune" and "jeunesse") appear more than eight hundred times. ${ }^{20}$ At about age thirty, the poet notes the first signs of his physical decline: some gray hair, a balding head, blackened teeth, and a cold body. He blames his love torments and his addiction to work for precipitating the aging process (I, pp. 959, 816, 806-7).

The Sonnets for Hélène provide a suggestive way to explore Ronsard's posture as an aged poet in love. He was fifty-four years old when his collection first appeared, in 1578. My discussion will refer to this work's last version, published in the 1584 edition of the OEuvres, one year before the poet's death. At that time, Ronsard was "starting to be inconvenienced by age's woes," in the words of Jacques Davy Du Perron ("commençant à se trouver incommodez des accidens de la vieillesse"). ${ }^{21}$ He incorporated a series of poems from the Amours diverses stressing his physical decline into the Sonnets pour Hélène. Furthermore, he explicitly stated his agefifty-six-in the dedicatory epistle to Neufville de Villeroy that precedes the Amours diverses, right after the Sonnets pour Hélène.

In his Vie de Ronsard that appeared shortly after the poet's death, Claude Binet noted that the cycle of poems for Hélène was written at the request

\footnotetext{
17 See chapter 2, the section on Castiglione.

18 Georges Minois, Histoire de la vieillesse en Occident de l'Antiquité à la Renaissance, pp. 339-64.

19 See Malcolm Quainton, Ronsard's Ordered Chaos. Visions of Flux and Stability in the Poetry of Pierre de Ronsard (Manchester: Manchester University Press, 1981), pp. 131-225.

20 Alvin Creore, $A$ Word-Index to the Poetic Works of Ronsard (London: Laney and Son Ltd, 1972).

21 J. Davy Du Perron, Oraison funèbre sur la mort de Ronsard, ed. M. Simonin (Geneva: Droz, 1985), pp. 105-6.
} 
of Catherine de Medici. ${ }^{22}$ Did the queen really ask Ronsard to compete with Petrarch's Canzoniere as Binet contends? Her intervention is doubtful, yet Ronsard's careful attention to Petrarchan writing practices, among many other references, is undeniable. ${ }^{23}$ In Petrarch's Rime Sparse, the young poet's pale face and melancholy reflect his endless love torments. In Ronsard's sonnets on the other hand, these signs refer to the lover's age. Indeed, a gloomy mood and an unhealthy condition are commonplaces in elders' portraits (I S 14, S 22; II, S 1, 2, 21, 24). ${ }^{24}$ The aged Tuscan protagonist was ashamed of his "youthful error;" Hélène's lover playfully inverts the expression of this feeling, while acknowledging that old age has caught up with him. He regrets the physical limitations imposed by advancing age when it comes to sensual pleasures:

J'ay honte de ma honte, il est temps de me taire,

Sans faire l'amoureux en un chef si grison... (II S 36, p. 397)

I am ashamed of my shame, it is time to fall silent, without playing the lover with such a gray head...

Now that he is in his fifties, it is time for him to follow Reason's law-that is, to go home and give up love (II, S 36 ) - or, rather, to give up writing love poetry. Whether his irony betrays his real pain and irritation at growing old is a moot point. Like a palimpsest, the sonnets unmask and subvert the hypocrisy of the poetic conventions to which they refer. Petrarch elaborated on the homophony between his beloved's name (Laura) and his poetic inspiration (l'aura); Ronsard too uses puns-he represents himself out of breath (hors d'haleine), painfully climbing the palace's stairs to meet Hélène. Instead of portraying himself as a helpless victim of love's fatal glance-another stereotype of Petrarchan verses and of the French medieval amour courtois - from the outset, he contends that his attraction to his lady is the result of a deliberate choice:

Vous seule me plaisez, j'ay par election

Et non à la volée aimé vostre jeunesse:

Aussi je prens en gré toute ma passion,

Je suis de ma fortune autheur, je le confesse. (I S1, p. 341)

22 Claude Binet, La vie de Pierre de Ronsard, ed. P. Laumonier (Geneva: Slatkine Reprints, 1969), p. 26.

23 Sarah Sturm-Maddox, Ronsard, Petrarch, and the "Amours", pp. 90-127.

24 The references indicate the Sonnets pour Hélène's book number (I or II), the sonnet number $(\mathrm{S})$, and the page number. 
You alone please me; I have by choice, not frivolously loved your youth: thus all my suffering pleases me. I confess that I am the author of my fortune.

His freedom of expression is the privilege of his age. He warns Hélène that he can find love elsewhere and bluntly tells her that she will be his last love affair ("derniere aventure," I, S 1, p. 341). ${ }^{25}$ He claims that he can control his feelings, although in other sonnets he acknowledges his impossibility not to love Hélène, thereby complying again with the Petrarchan conventions of love poetry. As critics have noted, Ronsard's denunciation of the topos of the chaste and faithful lover refers to a classical as well as to a French tradition celebrating sensual pleasures. ${ }^{26}$ Yet scholars have failed to notice how Ronsard capitalizes on his age in this respect. Boasting of his long experience, he acknowledges the illusory nature of love while fully enjoying such illusion. Moreover, he reacts to Hélène's Platonic conception of love as an old hedonist, repeatedly telling her that neither beauty nor youth last forever. He avoids any graphic descriptions of his physical decline, but warns Hélène of the flight of time. Her face will wrinkle, her body will lose its appeal, he notes; Hélène's old age will be like a shameful illness, and will force her to abandon all hope of being loved and celebrated in songs (II, S 43, pp. 400-1). She must comply with the moral code of the day, and the old lover is ready to break off if she does not: "Should virtue deceive me, farewell fair Mistress" ("Si la vertu me trompe adieu belle Maistresse" (I, S 1, p. 341).

In his posthumous biography of Ronsard, Claude Binet took great care to stress the chastity of the old poet's love for Hélène. ${ }^{27}$ This clarification corresponded to the climate of moral austerity in Catholic as well as Protestant circles. $^{28}$ Did Hélène de Surgères also put pressure on Binet in this respect? She was so concerned about her reputation that she asked Jacques

25 Ronsard ironically misquotes a line by Desportes inspired by Petrarchan and NeoPetrarchan sources. See Sonnets pour Hélène, ed. Malcolm Smith (Geneva: Droz, 1998), p. 30 , fni4.

${ }_{26}$ See Véronique Denizot, Ronsard. "Les Amours" (Paris: Gallimard, 2002), pp. 7-9, 129-30.

27 See Binet, La vie de Pierre de Ronsard, pp. 25-26. "Apres avoir chanté divers subjects il [Ronsard] voulut finir et couronner ses œuvres par les Sonets d'Helene, les vertus, beautez, et rares perfections de laquelle furent le dernier et plus digne object de sa Muse, le dernier parce qu'il n'eust l'heur de la voir qu'en sa vieillesse, et le plus digne parce qu'il surpassa aussi bien que de qualité, de vertu, et de reputation les autres precedens sujectz de ses jeunes amours, lesquels on peut juger qu'il aima plus familierement, et non cetuy-cy qu'il entreprit plus d'honorer et louer, que d'aimer et servir."

28 Ronsard, CEuvres, I, p. 1357. 
Davy Du Perron to add an introductory epistle to Ronsard's collection, stating that the poet's love for her was not "impudique" (immodest). Du Perron declined her request, replying, ironically, that Hélène's portrait was enough to rule out such suspicion. ${ }^{29}$ In the same way, Ronsard's ludic perspective on love in old age echoes the witty tone of courts' and salons' entertainments, and demonstrates the genius of a poet who capitalized on his age to renew the fashionable clichés of the day.

Interestingly, today's gerontologists observe that old age encourages an ironic perspective on the world, on others, as well as on oneself, 30 but Ronsard's collection for Hélène also emphasizes the aging poet's greater capacity for empathy. His defense of peace and his condemnation of hatred (two recurring themes in Ronsard's later poetry as a whole) are at the heart of his relations with his beloved. Conceived and published in a context of civil wars, his canzoniere conveyed a message of reconciliation and tolerance, even if an ideal agreement between Ronsard's aged persona and the young Hélène did not often seem possible. ${ }^{31}$

To young rivals such as Desportes, Ronsard's self-representation as an aged lover in the Sonnets pour Hélène was a masterful display of imagination, rhetorical skill, and erudition. Ronsard's self-portraits in the winter of his life were a pretext for poetic games, but old age was also a source of distress and melancholy that brought excruciating pain, as Ronsard claimed in the "Ode to Christofle de Choiseul" among several similar texts:

Non, ce n'est moy qui veut or'

Vivre autant que fist Nestor:

Quel plaisir, quelle liesse

Reçoit l'homme en sa vieillesse,

Eust-il mille talens d'or?

L'homme vieil ne peut marcher,

N'ouyr, ne voir, ny mascher:

C'est une idole enfumée

Au coin d'une cheminée,

Qui ne fait plus que cracher.

29 Perroniana, article "Gournay" (Cologne, 1694), p. 178.

30 See W. L. Randall and E. McKim, Reading our Lives. The Poetics of Growing Old (Oxford: Oxford University Press, 2008), p. 15.

31 See Sara Sturm-Maddox, Ronsard, Petrarch, and the "Amours", pp. 116-27. In a similar way, a posthumous sonnet published in the 1587 edition of the CEuvres represents two lovers growing old together: "Vous estes déjà vieille, et je le suis aussi./ Joignon nostre vieillesse et l'accollon ensemble,/Et faison d'un hyver qui de froidure tremble/(Autant que nous pourrons) un printemps adouci." (I, p. 507). 


\begin{abstract}
Il est tousjours en courrous Bacus ne luy est plus doux, Ny de Venus l'accointance: En lieu de mener la dance Il tremblote des genoux.
\end{abstract}

Si quelque force ont mes voeux, Escoutez, Dieux, je ne veux Attendre qu'une mort lente Me conduise à Rhadamante Avecques des blancs cheveux. (I, p. 902)

No, now I do not want to live as long as Nestor. What pleasure, what joy, does man receive in old age, even if he has a thousand golden talents? The old man cannot walk, nor hear, nor see, nor chew; he is a smoked form beside a fireplace, who only spits. He is always angry; does not find Bacchus sweet, neither Venus; instead of leading the dance; his knees are shaking. If my wishes have some power; Listen Gods, I do not want to wait for a slow death to lead me to Rhadamantus with white hair.

Whether the poet was telling the truth or not is a moot point. One thing, however, is certain: these complaints were part of Ronsard's efforts to win his patrons' support. In a poem dedicated to the Cardinal of Lorraine, the poet speaks of his sad and lethargic state of mind in the winter of his life (I, pp. 511-12). He is too old for love affairs, hence he has no poetic inspiration, and his existence no longer has any meaning. ${ }^{32}$

The wide range of tones of his self-portraits in old age confirms his belief that a fundamental law of transformation governs all living organisms. Likewise, metamorphosis reigns over his own poetic microcosm: as the years pass, Ronsard changes his skin, like a snake, as he puts it in a posthumous sonnet of the 1587 edition of his OEuvres (I, p. 507). In the Sonnets for Hélène, the poet refers to yet another metamorphosis, which also granted him immortality: while his body keeps aging, his love song for Hélène has the mythological permanence of Tithonus's songs (II, S 1 ). ${ }^{33}$

Similarly, Claude Binet's and Jean Galland's orchestration of Ronsard's posthumous collection Les Derniers vers capitalizes on metamorphosis to praise the poet's immortal glory. The first sonnets present the old and sick Ronsard "dictating and praying and dying altogether" ("dictant et priant

\footnotetext{
32 See François Rouget, "Ronsard et la vieillesse: expérience et représentation," in Vieillir à la Renaissance, ed. C. H. Winn and C. Yandell (Paris: Champion, 2009), pp. 93-105.

33 Eos had asked Zeus to give Tithonus, her mortal lover, the gift of immortality, but forgot to ask also eternal youth. Zeus changed Tithonus into a cicada.
} 
et mourant tout ensemble") in the editors' words. ${ }^{34}$ In the following sonnets, the poet's soul progressively liberates itself from his suffering body. As Ronsard's soul finds eternal rest, his most divine part-his poetryremains eternally young, perpetually renewing itself.

The imaginative versatility of Ronsard's self-portraits as an old man challenges any attempt to encapsulate them in one sentence. These representations confirm the truth of a French sixteenth-century proverb: "C'est grand peine que d'estre vieux: Mais il ne l'est pas qui veut" ("It is very painful to be old, but no one chooses it"). ${ }^{35}$

\section{Montaigne}

Petrarch's and Ronsard's self-portraits opened up the stereotypes of the chaste old man and the lustful elder to new literary and psychological insights. Montaigne, on the other hand, had a more pragmatic perspective on these questions. Like Petrarch and Ronsard, however, he viewed sexual love in terms of identity in the chapter "On some verses of Virgil" (III, 5). "Each one of my parts makes me myself just as much as every other one," he writes. Speaking of his sexual organ, he adds, "no other makes me more properly a man than this one" ("Chacune de mes pieces me faict esgalement moy que toute autre. Et nulle autre ne me faict plus proprement homme que cette cy," III, 5, p. 887/p. 822).

Scholars have seen in this chapter a criticism of the Neo-platonic perspective on love championed by Ebreo, Ficino, and Bembo. ${ }^{36}$ Montaigne mentions all three names in his essay, yet critics have omitted one aspect of his discussion, which concerns his intimate comments on sex and old age. In this respect, Montaigne's self-portrait as an aging man gives an ironic twist to the speech that Bembo-the fictional character that Castiglione modeled after the real Bembo-delivers on intellectual love and reason at the end of book four of the Courtier. Montaigne's remarks playfully elaborate on the reaction that Bembo's speech elicits from signor

34 Pierre de Ronsard, CEuvres complètes, ed. P. Laumonier, R. Lebègue, and I. Silver (Paris: STFM, 1914-74), vol. 18, p. 174. See also Rouget, "Ronsard et la vieillesse: expérience et représentation," pp. 93-105.

35 Jean Nucerin, Proverbes communs et belles sentences pour familièrement parler françois à tout propos, tres utiles et necessaires à toutes gens, composez par I. Nucerin (Paris: Picard, 1960), no page numbers.

36 See Barbara Bowen, "Montaigne's anti-Phaedrus: 'Sur des vers de Virgile' (Essais III, 5)” Journal of Medieval and Renaissance Studies 5, 1(1975), pp. 107-22. 
Morello: "without the body, love is a fantasy" (IV, p. 247) ${ }^{37}$ Montaigne only mentions Castiglione twice in the Essais; however, critics have pointed out numerous allusions to the Book of the Courtier throughout his work. In the chapter "On some verses of Virgil" (Essais, III, 5), which is my focus here, Montaigne's criticism of male hypocrisy towards women and marriage elaborates on the remarks made by Magnifico Giuliano in the third book of the Courtier. ${ }^{38}$ Such references indicate that the essayist consulted the 1585 Gabriel Chappuis French translation. ${ }^{39}$ In addition, Estienne de La Boétie, Montaigne's cherished friend, owned an Italian copy of the treatise, as did many members of the French upper classes.

Since the explicit theme of The Book of the Courtier is learning how to represent oneself-or rather an abstract self-to one's peers and to the prince, the courtier is required to deal with the social meaning of his age. In contrast, Montaigne situates the question of aging in a reflexive perspective, since he is the focus of his own work. Stressing his alleged withdrawal from the public sphere in a time of religious turmoil and civil wars, he claims to spend his later years with his books in the retreat of his castle, away from any political and professional obligations. At the same time, however, Montaigne's construction of his personal identity also emerges out of and through the representation of social relationships.

Never does Montaigne hide his age - quite the contrary, especially in the chapter "On some verses of Vergil": "an avowed ugliness and old age is less old and less ugly to [his] taste than another that is painted and glossed over," he writes ("Une laideur et une vieillesse advouée est moins vieille et moins laide à mon gré qu'une autre peinte et lissée," III, 5 , p. 895/p. 829). At the outset of this chapter, the essayist, who is in his fifties, considers his life both in terms of the past-looking back from old age - and the future-looking forward from youth. He sadly observes that age and illness have weakened his body and darkened his mood (III, 5, p. 842/p. 775). The number of his pleasures has decreased over time, although his sensitivity to their sensual qualities has actually increased in later life (III, 5, p. 843/p. 775). After some digressions his thoughts focus on sexual love, and he remarks on the pervasive social and moral hypocrisy surrounding such a vital and natural action. The use of literary quotations

\footnotetext{
37 See chapter 2, the section on Castiglione.

38 See Géralde Nakam, Montaigne. La Manière et la Matière (Paris: Champion, 2001), p. 141.

39 See Marcel Tetel, "The Humanistic Situation. Montaigne and Castiglione," The Sixteenth Century Journal 10, 3 (1979), pp. 64-84.
} 
allows Montaigne to add one more layer of comments on a matter he views as an essential part of his being, and indeed of life itself. At the end of the chapter, he reconsiders the misfortunes of his aging self and fantasizes on a way to cure his melancholy. A love affair, he observes, would cheer him up by bringing back his youthful energy and gaiety; yet he rejects this option as unrealistic on the basis of his age, for love is the privilege of youth. Furthermore, Montaigne's appearance and poor health do not give him any hope of seducing an attractive young woman.

This conclusion ironically provides a means of diverting his troublesome thoughts: he reads erotic verses from Virgil and Lucretius; the suggestive power of poetry awakens his sexual desire and chases away the gloom of old age. What he describes is a conscious effort by the mind to evoke the sexual pleasures that came spontaneously in youth. The reading of poetry enables him to obtain certain effects he can control at will, and whose intensity may even prove superior to actual sexual love. "Venus is not so beautiful all naked, alive, and panting, as she is here in Virgil," he contends ("Venus n'est pas si belle toute nue, et vive, et haletante, comme elle est icy chez Virgile," III, 5, p. 849/p. 782). But as he is well aware from the outset, his attempt is doomed to failure, for it is only a substitute for love:

Je ne m'esgaye qu'en fantasie et en songe, pour destourner par ruse le chagrin de la vieillesse. Mais certes il y faudroit autre remede qu'en songe: foible luicte de l'art contre la nature. (III, 5, p. 842)

I am merry only in fancy and in dreams, to divert by trickery the gloom of old age. But indeed it would require another remedy than a dream: a feeble struggle, that of art against nature. (p. 775)

He lucidly understands that this is the only means at his disposal to stimulate his mind and thereby to experience again some remnant of his youthful desire. ${ }^{40}$ "It is unjust to excuse youth for following its pleasures and to forbid old age to seek any," he notes in "Of Vanity" ("C'est injustice d'excuser la jeunesse de suyvre ses plaisirs, et deffendre à la vieillesse d'en cercher," III, 9, p. 977/p. 908). Old age's pleasures correspond to an increasingly demanding taste, and require more creativity since they are fewer. Montaigne's quest for pleasure is active in this respect and thus quite different from these decrepit men longing for their past physical vigor, whom Plato describes as nostalgically watching young athletes

40 See Olivier Guerrier, Quand "les poètes feignent": "fantasie" et "fiction" dans les "Essais" de Montaigne (Paris: Champion, 2002), pp. 256-78; and Mary McKinley, Words in a Corner. Studies in Montaigne's Latin Quotations (Lexington: French Forum, 1981), p. 80. 
(III, 5, p. 842/p. 775). The essayist feels too old for a love affair but compensates this loss by his vivid imagination: he becomes an expert at mentally increasing the intensity of sexual desire's effects. His fictitious pleasures correspond better to his aged and ailing body's limitations. Moreover, in contrast to youthful impatience, he now thoroughly enjoys the detours and the delays of love games (pp. 880-81/pp. 818-19).

By acknowledging the persistence of his sexual desire over the years, Montaigne questions the cliché of the chaste old man. His comments refer more specifically to Bembo's speech at the end of the fourth book of Castiglione's Libro del Cortegiano. Following a classical view (expressed in Plato's Phaedrus among other sources), Bembo praises the chastity of the aging courtier, free from the yoke of his youthful sexual desire and reaching the highest form of spiritual love through reason. This experience culminates in a contemplation of pure beauty, bringing the aged courtier close to divine perfection (IV, pp. 257-58). For Montaigne, this attitude turns us into insensitive beings who can no longer feel their bodies. Commenting on similar abstract views, he notes in another chapter:

Ils veulent se mettre hors d'eux et eschapper à l'homme. C'est folie: au lieu de se transformer en anges, ils se transforment en bestes; au lieu de se hausser, ils s'abattent. Ces humeurs transcendentes m'effrayent...("Of Experience," III, 13, p. 1115)

They want to get out of themselves and escape from the man. That is madness: instead of changing into angels, they change into beasts; instead of raising themselves, they lower themselves. These transcendental humors frighten me.... (p. 1044)

For Bembo, the old courtier, driven "by the force of his own imagination" makes a woman's "beauty much more beautiful than in reality it is" by situating it in a purely intellectual perspective (IV, p. 255). Bembo's description of love is in fact the overcoming and ending of the erotic experience of an ideal individual who possesses almost superhuman discipline and skills. In "Some verses of Virgil" on the other hand, Montaigne sees the abstract love of love praised in Bembo's speech as inconsistent, and puts it upside down: the essayist's imagination produces sensual and erotic images of women.

This is doubtless a reminder that physical, non-intellectual elements stimulate the author's creative energy. Furthermore, the essayist's personal experience proves more versatile than abstract age-related categories would lead us to believe. Indeed, the chapter challenges static accounts of the "life cycle" as a succession of fixed and repetitive stages-youth, 
old age - with a uniform and homogeneous set of binary oppositions. As Montaigne physically ages, his mind rejuvenates. To paraphrase mildly his own words, old age "puts more wrinkles on his body than in his mind" (III, 2, p. 816/p. $\left.75^{2}\right) \cdot{ }^{41}$ In "Some verses of Virgil," he describes himself as occupying his days with "toys and pastimes, like childhood" ("jouer aux noisettes et à la toupie," III, 5, p. 842/p. 776) to divert the gloom of old age. He knows very well that the reading of erotic Latin verses does not replace sex, but the fictitious nature of his game suggests that love is mostly the product of an illusion.

His experience was not lost on André Gide, an avid reader of the Essais. In his Journal, the seventy-two-year-old Gide writes on March 6, 1941:

Mon âme est demeurée jeune à ce point qu'il me semble sans cesse que le septuagénaire que je suis indubitablement, c'est un rôle que j'assume; et les infirmités, les défaillances qui me rappellent mon âge, viennent à la manière du souffleur, me le remettre en mémoire lorsque je serais enclin à m'en écarter. Alors, comme un bon acteur que je veux être, je rentre dans mon personnage et me pique de le bien jouer. Mais il me serait beaucoup plus naturel de m'abandonner au printemps qui vient; simplement je sens que je n'ai plus le costume qu'il faut pour cela. ${ }^{42}$

My soul has remained so young that I have the continual feeling of playing the part of the seventy-year-old that I certainly am; and the infirmities and weaknesses that remind me of my age act like a prompter, reminding me of my lines when I tend to stray. Then, like the good actor I should like to be, I go back into my role, and I pride myself on playing it well. But it would be much more natural for me to abandon myself to the coming spring: I simply feel that I no longer have the costume that it calls for.

A soul cannot concentrate continuously on serious matters, Montaigne observes, in fact it is for old persons "to trifle and play the fool, and for the young to stand on their reputation" ("C'est à nous à resver et baguenauder, et à la jeunesse de se tenir sur la reputation,” III, 5, p. 843/p. 776). From Antiquity to the Renaissance and to our time, this behavior seems one of old age's constant features. "Childhood goes, but childishness remains," Seneca wrote to Lucilius (Ad Lucilium 4, 2). This can be seen as a transition to another valued role, as Gide points out: that of the senex puer (the childish old man) who knows there is nothing to be got and enjoys a bearable present by delighting in trifles. In "On some verses of Virgil," this

\footnotetext{
41 Montaigne's words are: “Old age puts more wrinkles in our minds than on our

42 André Gide, Journal 1939-1949. Souvenirs (Paris: NRF, 196o), pp. 71-72. My translation.
} faces." 
posture rejuvenates Montaigne's perspective but affects his relationship with himself since it is the sign of a wisdom acquired from long experience. It prevents the aging essayist from "kicking and grumbling against the discomforts that nature orders [him] to suffer, but not from feeling them" ("regimber et gronder contre les inconvenients que nature m'ordonne à souffrir, mais non pas de les sentir," III, 5, p. 843/pp. 776-77). For him, wisdom is inherently of a "gay and pleasant quality" (III, 5 , p. 844/p. 778). Quoting Sidonius Apollinaris, he observes that "Gloomy things should be lightened with pleasantries" ("tetrica sunt amaenanda jocularibus," III, 5, p. 844/p. 778), and criticizes the portrait of old Crassus who "was never seen to laugh" (III, 5, p. $845 /$ p. 778 ).

Following Cicero's De Senectute, Castiglione's fourth book of the Courtier represents the elder courtier as embodying the moral and political values of his social milieu (IV, pp. 238-40). Montaigne's self-portrait has no such didactic goal. ${ }^{43}$ Observing that his first edition was in the year 1580 , he adds:

Depuis d'un long traict de temps je suis envieilli, mais assagi je ne le suis certes pas d'un pouce. Moy à cette heure et moy tantost sommes bien deux; mais quand meilleur, je n'en puis rien dire. Il feroit beau estre vieil si nous ne marchions que vers l'amendement. C'est un mouvement d'yvroigne titubant, vertigineux, informe, ou des joncs que l'air manie casuellement selon soy. ("Of Vanity," III, 9, p. 964)

Since then I have grown older by a long stretch of time; but certainly I have not grown an inch wiser. Myself now and myself a while ago are indeed two; but when better, I simply cannot say. It would be fine to be old if we traveled only toward improvement. It is a drunkard's motion, staggering, dizzy, wobbling, or that of reeds that the wind stirs haphazardly as it pleases. (pp. 894-95)

For Montaigne, the question of love in old age should be addressed in terms of tactics and practices of everyday life, rather than via ideology or compliance with a set of coded behaviors. Since later life is a time of physical decline, it requires adaptability. ${ }^{44}$ The posture of the senex puer epitomizes such flexibility of the mind. Fantasizing about sex through the suggestive erotic power of Latin poetry may indeed be a vain exercise for a senior, but the very possibility of entertaining these youthful thoughts has

43 "Others form man; I tell of him, and portray a particular one, very ill-formed, whom I should really make very different from what he is if I had to fashion him over again", he remarks at the opening of the chapter "Of Repentance" (III, 2, p. 804/740).

44 See chapter 4 , section 3 on this aspect. 
a therapeutic effect that capitalizes on the mind's inconstancy, and thus on its ability to divert the gloom of old age. The success of this tactic, however, is relative, for it cannot undo the cause of Montaigne's melancholythe biological process of aging - and its effect wears off with time.

As Montaigne grows old, he places sexuality in the broader context of various forms of pleasures, and dispels many prejudices. He feels different from in his youth, but neither inferior nor superior to what he once was. In "Some verses of Virgil" he describes himself as having less vigor and vivacity than in his youth, but finds that he has more time for cultivating the present instant. ${ }^{45}$ This is a heuristic, experimental approach that puts its faith in aging as a productive period of life. What Montaigne acquires through his experience of aging, whereby he sees himself and the world with different eyes from those of the youth, is frankness; indeed, he is quick to point out that old people are traditionally granted more freedom of speech than young ones. In "On some verses of Virgil," this freedom is obvious in his focus on sex-a rather contentious and shocking topic, as he remarks. Throughout this chapter, Montaigne acknowledges aging as problematic and attempts to create forms more adequate to such a complex experience. The standard oppositions of old age and youth, wisdom and folly, lust and chastity prove irrelevant when applied to the later life of a particular individual. The essay (a genre in many ways related to the dialogue) gives Montaigne a flexible way to register the ambiguities and ambivalences of his aging self.

In this respect, "On some verses of Virgil" stresses the difficulty of being both the object and the subject of a discussion on a topic such as age. For if the speaker is old, as Montaigne observes elsewhere,

il ne peut juger du sentiment de la vieillesse, estant luy mesme partie en ce debat; s'il est jeune, de mesme; sain, de mesme; de mesme, malade, dormant et veillant. Il nous faudroit quelqu'un exempt de toutes ces qualitez, afin que, sans praeoccupation de jugement, il jugeast de ces propositions comme à luy indifferentes; et à ce conte il nous faudroit un juge qui ne fut pas. (“Apologie de Raymond Sebond," II, 12, p. 600)

he cannot judge the sense perception of old age, being himself a party in this dispute; if he is young, likewise; healthy, likewise; likewise sick, asleep, or awake. We would need someone exempt from all these qualities, so that with an unprejudiced judgment he might judge of these propositions as of things indifferent to him; and by that score we would need a judge that never was. (p. 552)

45 See chapter 4 , section 3 on this aspect. 
"On some verses of Virgil" questions abstract representations of old age yet does not challenge social decorum and convenances. Throughout this essay, sexual love is essentially a reading and writing experience rather than a real one. ${ }^{46}$ In addition, Montaigne's lucid self-analysis eliminates the risk of associating himself with those aging lovers whom Federico, in the Book of the Courtier (II, p. 78), accuses of making fools of themselves. Montaigne's self-portrait here is not a dialogue, like Castiglione's work, yet it also is conceived as a social game. This game is based on conversations with books rather than with a lively circle of aristocrats gathered at the court of Urbino, but like Castiglione's conversations, Montaigne aims at stimulating his readers' imagination-especially the imaginations of young and beautiful women - as much as his own. With this targeted audience, he establishes a friendly relation, quite similar to the witty exchanges between Castiglione's protagonists, with their light-hearted way of teasing one another. To these implied readers-his accomplices-Montaigne addresses a humorous plea for their understanding and affection. He asks to be esteemed for who he is, for his wit, his honesty, his determination to rid his mind of despair, and his efforts to unmask the hypocrisy of stereotypes of love in old age. He also advocates friendly relations between men and women, youth and elders. Obviously, he would be the first to reap the reward of this strategy of seduction.

Ironically, in "On some verses of Virgil" the aging Montaigne displays the social and intellectual qualities of Castiglione's young courtier. He gracefully adapts to all circumstances, even those whose effects are out of his control, such as growing old; his conversation proves both sound and entertaining (especially for women); he perceptively stresses his own value without being pretentious or offensive. He has the same aesthetic sense of negligence and effortlessness that the youthful courtier is required to portray in order to obtain recognition, praise, and favor. Montaigne's frankness and his refusal of artificiality are a form of sprezzatura, the master trope of the courtier. Castiglione's Count Ludovico defines it in the following terms: "to conceal all art and make whatever is done or said appear to be without effort and almost without any thought about it." (I, p. 32).

To speak about aging is to enter an area in which some basic anxieties and aspirations about human life are expressed. Castiglione's Book of

46 See Floyd Gray, Montaigne bilingue. Le latin des "Essais" (Paris: Champion, 1991), pp. 99-118. 
the Courtier forcefully reminds us that every society creates the old men it deserves. Montaigne's "On some verses of Virgil," on the other hand, stresses the complexity of personal experience, and suggests ways of aging gracefully in a manner that neither imprisons us at the level of the particular nor eradicates the specificity of this process by lapsing into abstract generalities.

"It is a myth that old age is typically a time of passivity," an older English woman observed in the 1980 s. "The truth is closer to the opposite; since later life is a time of sharp change, it demands a special responsiveness and imaginative adaptability." 47 Four centuries before her, Montaigne had already capitalized on a similar perspective. "Since it is the privilege of the mind to rescue itself from old age, I advise mine to do so as strongly as I can," he noted in "Some verses of Virgil." "Let it grow green, let it flourish meanwhile, if it can, like mistletoe on a dead tree" (III, 5, p. 844/p. 777).

\section{Pasquier}

"Nobody can be physically young and old at the same time," Saint Augustine contends. "Yet, one can be both intellectually; and have a youngfast-and old-wise-mind." 48 His remark applies perfectly not only to Montaigne but also to one of the essayist's friends and admirers: Etienne Pasquier. For our purposes, Pasquier's Pastorale du vieillard amoureux (Pastoral of the Old Man in Love) and Jeus Poétiques (Poetic Games) are especially interesting. ${ }^{49}$ His contemporary, Scévole de Sainte-Marthe, praised Pasquier's sociable manners and witty mind ${ }^{50}$ — two qualities well appreciated in his social and intellectual circle. In contrast to Ronsard (whom he knew and whose works he admired), Pasquier seemed to have been blessed with a healthy old age until his death at age eighty-six. Like

47 Quoted in Pat Thane, History of Old Age in English History (Oxford: Oxford University Press, 2000), p. 245.

48 Saint Augustine, Retractationum libri II, ed. A. Mutzenbecher (Turnhout: Brepols, 1984), vol. 1, chapter 26, p. 8o. My translation.

49 Etienne Pasquier, Oeuvres complètes, 2 vols. (Geneva: Slatkine Reprints, 1971). References to La Pastorale du vieillard amoureux are to this edition and are incorporated into the text. Les Jeus Poétiques, ed. Jean-Pierre Dupouy (Paris: Champion, 2001). References to Les Jeus Poétiques are to this edition and are incorporated into the text. All translations of both works are my own.

50 Scévole de Sainte-Marthe, Opera, tum poetica, tum ea quae soluta oratione scripsit. Scaevolae Sammarthani Lucubrationum, pars altera, qua continentur Gallorum doctrinae illustrium, qui nostra patrumque memoria floruerunt, elogia (Paris: Durand, 1616), pp. 277-78. 
Montaigne, in his Pastorale du vieillard amoureux Pasquier refused binary stereotypes of young-versus-old, while providing us with an inside view of the pastimes of his worldly coterie.

A brief account of the events surrounding the composition of this work is called for. Soon after her marriage with the influential Albert de Gondi, Claude-Catherine de Clermont, the Duchess of Retz, ${ }^{51}$ became the center of an intellectual court. That she was esteemed by her contemporaries is shown in the praise she received and the numerous works dedicated to her. Well before the Marquise de Rambouillet, she opened her salon to humanists, politicians, courtiers, and writers who came to share their hostess's passion for conviviality and conversation. The writers Philippe Desportes, Pontus de Tyard, Jean-Antoine de Baïf, and Amadis Jamyn were among the duchess's regular guests.

In a letter to his friend Pierre Airault dated December 1591, Etienne Pasquier writes that some three weeks earlier he had been invited to a dinner party at the home of the duchess. He describes the range and breadth of conversation, from personal concerns to general comments on justice and work. The guests spoke freely about the social and political upheavals of the day which were on everyone's mind since France was in the midst of a civil war. After such serious matters, the discussion turned to love, a topic well-suited for a festive evening, leaving plenty of room for wordplay and wit. Pasquier was well equipped to contribute to this exchange since his two dialogues entitled the Monophile address this very question, but he was immediately interrupted by the duchess, who wanted to stir things up by declaring that it was inappropriate for an old man to discourse on love. The word she used was "bon homme," which, according to Antoine Furetière's Dictionnaire universel (1691) meant a "harmless old man." ${ }^{52}$ Quickly catching on to the duchess's game, Pasquier, then sixtytwo years old, reports to Airault that he pretended to see her comment as a grave insult, an "eighth mortal sin." The offensive word "bon homme," he said ironically, reduced him to "a piece of garbage" ("une pièce de rebut," II, pp. 897-98).

The incident did not generate any special comment but gave rise to a sparkling war of wits. Retz's guests turned their attention to a questione d'amore: "who can better speak of love, a young man or an old

51 Catherine de Clermont (1543-1603), formerly Maréchale of Retz, became Duchess in 1582 .

52 Antoine Furetière, Dictionnaire universel (Rotterdam: Arnout and Reinier Leers, 169o), p. 98 . 
one?" Debates, to be sure, often allow successive speakers to contradict one other, the assumption being that dialogues between opposed viewpoints are a way to the truth. Here, however, ingenious improvisations were more important than finding the eventual right answer. Not unlike actors from the commedia dell'arte improvising on set patterns, members of the drawing-room set moved from spoken to written performances, taking up personae and engaging in discussions or texts on familiar issues. ${ }^{53}$ Since the Ancients, the moment of mealtime stands above all other group pleasures; dialogue and conviviality give rise to playfulness. For Georg Simmel, "in purely sociable conversation the content is merely the indispensable carrier of the stimulation, which the lively exchange of talk as such unfolds...that something is said and accepted is not an end in itself but a mere means to maintain the liveliness of the mutual understanding, the common consciousness of the group." 54 The debate on love gave the duchess's guests a great opportunity for such interaction; it stimulated jokes and puns, delightful to an intellectual coterie bound together by a common literary culture. Disagreement and midly provocative propos lent spice to the exchanges; inviting objections and debate was but a way of reinforcing consensus and agreement among the guests.

Inspired by the incident of this soirée, the next day Pasquier wrote a Pastorale du vieillard amoureux, dedicated to the Duchess of Retz. In his letter to the duchess, he offered a challenge to boys without experience in love, and claimed that his gray beard gave him special privileges to dispense kisses in a manner that young men would never attempt. After being circulated in manuscript, the Pastorale du vieillard amoureux appeared in print with a preface consisting of the letter to Airault and the dedication to the Duchess of Retz, followed by a short poem. In addition, Pasquier's letter to his friend the lawyer Pierre Pithou was appended to the piece and served as a general comment on the incident. Like the dinner conversation from which it originated, Pasquier's work refers to a number of precepts required in an exchange between people of refinement.

It comes as no surprise that old age should be the focus of a social game about words. Pasquier was far from being the only graybeard in Catherine

53 Julie Campbell, Literary Circles and Gender in Early Modern Europe. A Cross-Cultural Approach (Burlington, VT: Ashgate, 2006), p. 74, stresses the continuity between oral and written communication: a conversation inspires Pasquier's written dialogue, this dialogue circulates in manuscript and is ultimately recorded in print.

54 Georg Simmel, “The Sociology of Sociability," American Journal of Sociology 55 (1949), pp. 259-6o. 
de Clermont's literary circle; Pontus de Tyard, a regular guest of the Retz salon, was seventy years old in 1591. The duchess herself was forty-eight, but Pasquier, diplomatically, had no desire to raise this issue. Conceived as a form of after-dinner entertainement, his Pastorale du vieillard amoureux capitalizes on a confraternity of speech, manners, thoughts, and interaction to display Pasquier's rhetorical skills and esprit d'à propos. An exercise in tact and finesse, an elegant demonstration of the refined ease of an author who can turn casual conversation into art, the Pastorale du vieillard amoureux presents alternatively positive and negative views on love in old age-just like the debate from which it sprang. As a brilliant lawyer, Pasquier was well equipped to act as the old man's attorney, prosecutor and judge. At the opening of the pastoral, the poet introduces the characters of the dialogue: the shepherd Tenot, the shepherdess Catin, and the god Pan. Old Tenot is in love with young Catin, and tries to convince her of the advantages of an older lover. An older and weaker body, he contends, imposes measure on sensual pleasures, and increases man's wisdom. Personally, Tenot does not feel his age and maintains that chronological age explains nothing, because it is an arbitrary index. Since aging, as applied to human existence, implies a multiplicity of perspectives (biological, medical, psychological, etc.), Tenot criticizes abstract representations of old age as a distinct stage of life with a common set of fixed features; he argues that metamorphosis is the essence of life. Commenting on the natural cycles of growth, maturation, and decay, he encourages Catin to enjoy every moment of her ephemeral youth, for nothing is permanent in this inconstant world, and death can come at any age. When it comes to love, Tenot is quick to boast of his age: as an older lover, he is discreet and faithful; moreover, his conversation is much livelier than that of a young man. His understanding of the nature of passion is a counterpoint to youth's foolish sexual impulse.

Catin then replies from a youthful perspective and points out old age's sour aspects. She criticizes Tenot for talking too much about love without acting. She dreams of a handsome young man who would love her night and day. There is a season for everything, she concludes, and Tenot should behave according to his age; consequently, she sends him back to his glass of wine and his beer, which are more suitable to his condition than love games. Each of the shepherds' speeches has exactly the same number of lines, thereby emphasizing the passing of time. Finally the great god Pan steps forward to reconcile the two shepherds, and advocates a partnership between old age and youth. The ideal is based on balance: Tenot and Catin are both right, Pan contends, in fact, they need one another. From 
the time of the Ancients, Pan was a familiar character of the pastoral landscape; his well-known sexual power eliminated any possible remark on Tenot's eventual impotence. When it comes to love, Pan maintains, age discrimination is a false problem since passion is similar to fire: the most enjoyable and intense flame comes from "burning a mixture of branches at once tender and old" (II, p. 9o6). The dialogue ends with alternate songs by the two lovers whose laughter chases away the gossipers. The final song celebrates the couple's happiness, sealed with a kiss.

Pasquier did not expect his audience to believe old Tenot and young Catin's love story. "I want to make it clear that I am not serious," he wrote to Airault (II, pp. 899-900). In his letter to the lawyer Pierre Pithou dated a month after the Retz dinner, he again stressed the ludic tone of his Pastorale du vieillard amoureux:

Puisque la vieillesse apporte mille incommoditez de corps et d'esprit quant et soy, je me veux chatoüiller pour rire, malgré la malice du temps, et de mon aage, et en ce faisant, bannir le chagrin au moins mal qu'il me sera possible, et me resjoüyr sans pecher. A la charge que si je desplais à quelques-uns, je veux qu'ils sçachent qu'aussi me desplaisent-ils, et si voulez que je passe plus outre, leur desplaisir est mon plaisir." (II, pp. 911-12).

Since old age brings a thousand inconveniences to the body and the mind, I want to tickle myself and laugh despite the evils of time and old age, thereby chasing sadness in the least possible harmful way, and rejoicing sinlessly. Now if I displease a few, I want them to know that they displease me too, and if you want me to go further, their displeasure is my pleasure. (II, pp. 911-12)

Social games of refined and witty expressions of desire were among the favorite pastimes of the French literary circles of the end of the sixteenth century, and jokes on intergenerational love were not exceptional. In 1579, Henri III pretended to fall in love with the old Duchess of Uzès and initiated with her a playful exchange of amorous verses that circulated widely among members of the court. ${ }^{55}$ In a similar way, the Duchess of Retz's Album de poésies - a collection of verses collectively and anonymously written by Catherine de Clermont's guests - contains poems praising the superiority of aging lovers over young and inexperienced ones. ${ }^{56}$ Pasquier's pastoral obviously has the light and witty tone of such exchanges, which

\footnotetext{
55 See Jacqueline Boucher, Société et Mentalités autour de Henri III (Paris: Champion, 2007), pp. 728-29.

56 See Catherine de Clermont, Album de poésies (Manuscrit français 25455 de la BNF), ed. Colette H. Winn and François Rouget (Paris: Champion, 2004), p. 75.
} 
made the reputation of the Retz salon. One may even think that Catin and Tenot's conversations alluded to and reshaped a great range of what was said at the banquet. If so, the different meanings and connotations imposed on the guests' exchanges would have been easily identified by anyone who attended the event.

More importantly, Pasquier's work playfully challenged powerful stereotypes of love in old age. On this question, books of manners such as the widely read Libro del Cortegiano set the tone in sixteenth-century French courtly and aristocratic circles. Six years prior to Retz's dinner party, Gabriel Chappuis's new French translation of Castiglione's dialogue was published by the Parisian librarian and printer Abel L'Angelier, with whom Pasquier collaborated. It was, of course, impossible to assimilate Pasquier to the old man who, in Fregoso's stern words in the Cortegiano, makes a fool of himself in others' eyes by sending love letters and chasing young girls (II, pp. 77-78). In Pasquier's work, love is the pretext for witty and friendly exchanges that echoed the dinner guests'gentle way of teasing one another at the banquet. The pastoral's playful rhetoric of praise, blame, and reconciliation follows the model of Poggio Bracciolini's poem "Should an Old Man Marry?" - a paradoxical praise of the marriage of a fifty-six-year-old man to an eighteen-year-old girl. ${ }^{57}$ Yet while following such rhetorical tradition, Pasquier's dialogue does not challenge social decorum and convenances; from the start, the aging author carefully dissociates himself from old Tenot. In a short poem concluding his letter of dedication to the Duchess of Retz, he wrote:

...ne pensez pas pourtant

Qu'un jeune object m'aille ainsi tourmentant,

Comme j'en fay, par mes vers contenance:

Je ne vy point en cest heur malheureux. (II, p. 901)

Don't think however that a young object is tormenting me like this, as I state in my verse: I don't live in this unhappy state.

Likewise, the pastoral's dedication to Retz eliminates any personal reference to Pasquier and vaguely alludes to a fictitious friend as the target of the offensive word "bon homme" uttered by the duchess. The idea of substituting an anonymous old man for Pasquier himself was an effective way of whetting the curiosity of the pastoral's potential audience, and

57 Gian Francesco Bracciolini, Un Vieillard doit-il se marier? ed. and transl. Alcide Bonneau (Paris: Liseux, 1877). This work was familiar to Pasquier's literary circle and inspired Pierre de Ronsard's first sonnet of the second book of the Sonnets pour Hélène. 
renewing the discussion that took place at the dinner party. The persons who attended the banquet would, in all likelihood, have been eager to reveal to other members of their coterie the real identity of the victim, along with the details of the conversation that took place that evening. If table conversation is the mode of production, conception, and reception of Pasquier's work, gossip serves as its discursive model. I do not mean to imply that the pastoral is just a form of gossip, but that its self-referential apparatus leads us to think about what it has in common with gossip. Like an oral story, it passes by word of mouth: Pasquier tells the little story to Airault in an introductory letter; his letter of dedication to the Duchess of Retz mentions a fictitious old friend who allegedly relates his misfortune to Pasquier who, in turn, recounts his story in his pastoral poem; Pasquier then gives further details in a letter to Pierre Pithou. The spreading of the news shows the network mode of "gossip" even if what is said is communicated in a way that is distinct from gossip's more typical self-referential techniques ("I shouldn't tell you this, but...").

Gossip is a powerful way for social groups to constitute themselves, to maintain cohesion and to reinforce convivial relations. One does not gossip just to anyone: the inclusion of some in the circle of gossipers to the exclusion of others serves to identify a group that has common interests or concerns. The circulation of information within the network constituted by the Retz coterie also serves to keep open, phatically, channels of friendly communication dear to its members. Gossip frequently functions to identify a scandal, serving the circle's need to explore its system of values: what constitutes "scandal" for a given group is an indicator of how the group keeps a check on behavior it considers illegitimate, or unusual, and on things worth discussing. In a sense, gossip reveals what one always "knew" yet never realized until it was articulated. ${ }^{58}$ Thus old age and the physical decline that goes with it need not marginalize someone socially, but can represent the most creative and imaginative period of a life, especially when it is a question of orchestrating the pleasures and pastimes of a learned and worldly circle.

The story of old Tenot in love with young Catin illustrates how a man who looks old in the eyes of another can be the most youthful and convivial of guests. In this respect, Pasquier's pastoral is an ironic response to negative stereotypes of the old man as unattractive, impaired, and

58 See Ross Chambers, "Gossip and the Novel: Knowing Narrative and Narrative Knowing in La Fayette and Proust," Australian Journal of French Studies 23, 2 (1986), pp. 212-32. 
socially dysfunctional, as depicted by the youthful Fregoso in the second book of Castiglione's Cortegiano (II, p. 78). Examples of such negative commonplaces already appear in Aristotle's Rhetoric (II, 12-14). By gracefully adapting to a process whose effects are beyond his control-growing old-Pasquier stresses the value of his age without being pretentious or offensive. Such an ideal (drawn from Cicero's notion of urbanitas, with its emphasis on politeness, grace, and elegance in social behavior) is a key aspect of the social identity of the cultural elite gathered in French salons toward the end of the sixteenth century. As a good guest, Pasquier is at pains to please his hostess and her lively circle of learned friends, for nothing makes a feast more jovial than laughter and trust. The genre of the pastoral is suggestive in this respect: to fall back on a conventional feature of Arcadia, the sum of young Catin's and old Tenot's respective ages becomes the Golden Age. Youth and age come together: pleasure and wisdom become conjoined, love and contemplation are united.

Pasquier wrote in a letter to his friend Pierre Pithou a few weeks after Retz's dinner party: "Did you ever see anything as funny as this? That I, in the winter of my age, in the midst of France's upheavals, gave myself a new career, and amused myself writing a love pastoral?" (II, pp. 911-12).

The dedication of the pastoral to the Duchess of Retz was a way for Pasquier to remain a key player at table conversations despite, and ultimately because of the physiological changes taking place in his body. For Linda Hutcheon, "irony is a relational strategy in the sense that it operates not only between meaning (said, unsaid) but between people (ironists, interpreters, targets). ${ }^{59}$ We do not have a record of the duchess's reaction to Pasquier's Pastorale du vieillard amoureux, but she had every reason to enjoy its wit. A refined and learned lady widely admired for her erudition and literary taste, the duchess expected a work to be sound, entertaining, and elegant. The pastoral certainly struck the right note. In addition, Retz was part of the theater-loving circles of Catherine de Medici, Marguerite de Valois, Henri III and Henri IV, who were so taken by Italian actors that they attracted some of the best ones to France and frequently commissioned their performances. As an intimate friend of the royal family, the Duchess of Retz took part in court entertainments, and performed in masques; most famously in the Ballet comique de la Royne. ${ }^{60}$ Pasquier's work capitalizes on Retz's infatuation with elements of the pastoral

59 Linda Hutcheon, The Theory and Politics of Irony (London: Routledge, 1994), p. $5^{8 .}$

60 Julie Campbell, Literary Circles and Gender in Early Modern Europe, pp. 77-81. 
tradition, especially with Sannazaro's Arcadia, a work which, incidentally, addresses the issue of old men in love. The duchess's aristocratic female friends were often referred to as nymphs, muses, and goddesses from classical antiquity; Catherine de Clermont was Dictynne (a nymph from Crete said to be an attendant to Diana), and her salon was called le salon vert. Moreover, from Clément Marot to Pierre de Ronsard and onward, Tenot and Catin were conventional names for French pastorals, but they also transparently alluded to the first names of Etienne Pasquier and Catherine de Clermont. In this respect, the pastoral playfully subscribed to the claim that "all the world is a stage": "Look at this old man entering the stage to play his character" (II, pp. 899-90o), Pasquier wrote in his letter of dedication to Retz.

The pastoral genre has often been viewed as offering a nostalgic representation of lost youth, but a significant proportion of them elaborate on the opposite perspective. Indeed, since Virgil's first Eclogue, the bucolic world is the ideal home of old age. In Virgil's work, old Tityrus "reclining at ease on a bench beneath the cover of a tree" enjoys the "god-ordained" otium or peaceful leisure intrinsic to the pastoral ideal. "Fortunate senex" declares the unhappy Meliboeus who is forced to leave his land, whereas Tityrus is permitted to stay. ${ }^{61}$ For centuries, Virgil's first Eclogue was required reading for any beginning student of Latin. Pasquier's reference to this familiar work shows his esprit d'à propos since Tenot's love for Catin echoes Tityrus's love for young Amarillys. Pastorals were originally the improvised songs of Greek shepherds; in the same spirit, the Pastorale $d u$ vieillard amoureux is eloquence in the making, and its readers were improvisers who would judge the work on the spontaneity of its effects (a spontaneity artificially recreated in writing), on its ingenious use of words, and on the good manners of its author. As Pasquier observed in his letter to Airault, the dinner guests who witnessed the "bon homme" incident were all "beaux esprits" who excelled in the dissection of feelings, feigned passions, and emotions. Pasquier was a master at such improvisations, if we are to judge by the literary competitions on La Puce and $L a$ Main that he organized in Poitiers and in Troyes, respectively. In both cases, a daily life event (a flea that Pasquier claimed to have seen on Catherine des Roches's breast, the absence of hands in a painting of Pasquier as a lawyer) becomes the pretext for light pieces aiming at reinforcing the

${ }^{61}$ Virgil, "First Eclogue", in Eclogues, ed. and trans. R. Coleman. (Cambridge: Cambridge University Press, 1977), ll. 1, 6,46. 
conviviality of a closely-knit literary coterie. Such works focused mostly on style since they offered the poet an opportunity to accumulate ingenious turns of phrase and paradoxes. The slighter the content, the higher the level of wit, grace, and subtlety of the expression. ${ }^{62}$

Similarly, the debate on love that took place at Retz's dinner party called for equal contributions from the guests. Games are a powerful means of social integration; they require the players' involvement and rely on a mutually congratulatory process. Pasquier could admire his own private wit, as he states in a short poem at the end of the dedication of the pastoral: "I am in love only with myself, and don't think of another misfortune in my heart" ("Je suis de moy seulement amoureux, Et autre mal en mon cœur je ne pense" II, p. 9o1). By addressing the questione d'amore at the dinner party debate in terms of experience, Pasquier did more than show an old man's superiority in speaking of love; he pointed out how important it is for young people to draw on their elders' rhetorical skills and experience. Hence his pastoral complied with the three goals of rhetoric as defined by Cicero: pleasing, moving, teaching.

These imperatives are embodied in an apparently artless dialogue that reflects the wit of the Retz salon. An ideal guest was required to talk about everything and nothing, to be in turn serious and frivolous, profound and amusing. Yet a meaningful experience emerges from the chance events that produce it. The guests' infatuation with Arcadia, or with similar utopian images, was not merely an escape from the Religious Wars and social conflicts of the day. Even if Pasquier's Pastorale du vieillard amoureux was written in response to a trivial incident at a dinner party, it conveyed a wider plea for tolerance, peace, and harmony. Interestingly, the Pastorale du vieillard amoureux depicts old Tenot as dispossessed. Everyone knew that in Virgil's first Eclogue, Meliboeus's exile was the consequence of the Roman civil wars. ${ }^{63}$ Pasquier's own misfortunes at the time of the Pastorale were not unrelated to that of Meliboeus: in 1588, when he left Paris to attend the Etats Généraux at Blois, he sojourned in Tours where Henri III had established the Parlement and the Chambre des Comptes. "I have lost all my wealth because of the Ligue" (II, pp. 897-98), Pasquier writes to Airault in the letter prefacing his pastoral. When he returned to Paris in 1594, his house at the Quai de la Tournelle had been sacked.

62 Gisèle Mathieu-Castellani, Les Thèmes amoureux dans la poésie française (1570-160o) (Paris: Klincksieck, 1975), pp. 216-18.

63 Meliboeus is the tenant and not the owner of his land; he is in exile because his landlord's land has been given by Augustus to a veteran. 
Four years earlier, in May 1590, one of his sons, François-René, was killed at the siege of Meung-sur-Loire. Pasquier's wife, Françoise Belin, who had been jailed by the Parisian ligueurs, died the following October, soon after her release. ${ }^{64}$ Despite the upheavals of these wars, so lucidly described in Pasquier's letters, the Pastorale du vieillard amoureux celebrates the pleasure of storytelling. As the author ironically observes in his letter to Pierre Pithou, he lost everything during these wars except his mind (II, pp. 899-900). No wonder he appended this letter to his pastoral: it was a way of stressing the therapeutic function of social games and entertainments at a time of political instability and despair.

Interestingly, Catherine de Clermont was a member of the Académie du Palais established by Henri III. Like the Académie de musique et de poésie founded by Jean-Antoine de Baif, this institution capitalized on the regulation of social and artistic exchanges to promote France's unity of language, culture, and ethical values, and ultimately played a role in restoring peace in the kingdom. In a lighter vein, the pastimes of the Duchess of Retz's circle and Pasquier's pastoral complied with these goals: by stressing the values of friendship, conviviality, and leisure, they encouraged social harmony through games, music, and poetry. Debates, dialogues, speechmaking and speech evaluation were at the center of the two Académies' meetings, offering their members practical training for political negotiation. Such ideals, however, reflected the values and interests of their limited and select audience: despite their collaborative spirit, the Académies reinforced the gap between a small intellectual French elite and the rest of the kingdom. In this respect, Pasquier's Pastorale du vieillard amoureux participated in the creation of a convivial and tolerant French aristocracy of letters, epitomized by the banquet from which his work originated. "Age is an issue of mind over matter. If you don't mind, it doesn't matter," Mark Twain wryly observed. ${ }^{65}$ Several centuries before him, Pasquier's Pastorale du Vieillard Amoureux had already offered a witty demonstration of this.

In his Jeus Poétiques (1610), the eighty-one-year-old Pasquier had an even more ambitious goal. He represented his éducation sentimentale from youth to old age, ironically calling into question the division of life into ages with a common set of fixed features, and challenging the reader

64 Paul Bouteiller, Recherches sur la vie et la carrière d'Etienne Pasquier, historien et humaniste du XVIe siècle, (Paris: Editions I.S.I., 1989), pp. 33-48.

65 See http://beliefnet.com/Holistic-Living/index.aspx. Accessed March 14, 2013. 
to view him as an old man (p. 106). Les Jeus Poétiques contrasts the poet's own sentimental life with a series of commonplaces that reflect conventional views of the stages of life, thereby stressing that such set "stages" are only meaningful in terms of individual responses to them. The collection is a montage, since the octogenarian author recycled some of his earlier poems. Revisions had been made, new poems were added, while others were deleted; a coherent narrative emerged delineating Pasquier's own stages of the life cycle.

More importantly, Les Jeus Poétiques blurs the distinction between the practice of a literary style, and the shaping of one's identity over time. The collection is, in many ways, an anthology of French love poetry's major rhetorical trends in the second half of the sixteenth century, and playfully reviews the amorous behaviors that inspired Pasquier's own poetry during his long career. The author knew that he was dipping into material that any member of his literary and social circle would recognize, and therefore would enjoy understanding the allusions. Stereotypes of old people describe them as absorbed in contemplating their past and not interested in the present, but such was not Pasquier's case since he adapted his verses (some of which had been published as early as 1555) to the audience of 1610, when Les Jeus Poétiques was published.

The work contains five sections, but to examine them separately is to lose the sense of the complex interactions between the "self" and literature that is at the heart of this work. Pasquier's collection engages its readers with an experience of the instability of the literary canon as a product of shifting tastes. Moreover, it playfully shows that, as Foucault notes, there is no such thing as an a priori theory of the subject independent of specific forms of knowledge and a certain number of practices. ${ }^{66}$

What marks Les Jeus Poétiques is the imprint of Pierre de Ronsard on Pasquier's successive self-definitions, as both poet and lover. As the most versatile poet of his time, Ronsard had excelled in every form and possible expression of desire, tirelessly drawing his inspiration from Italian, Greek, and Latin sources to enrich the French literary repertoire. Pasquier's acknowledgment of Ronsard's lasting influence on his own career was a way to share in the glory of this famed poet. The old writer could proudly show his 1610 audience that he had been an active member of the famous Pléiade which, under Ronsard's leadership, gave France a renewed cultural prestige. This claim reappears in book 7 , chapter 6 of the Recherches

66 See Foucault, "The Ethic of Care for the Self as a Practice of Freedom", p. 10. 
de la France, a work that Pasquier was writing at the same time as the Jeus Poétiques (Oeuvres, I, p. 701). Likewise, in a letter dating between 1589 and 1605 , Pasquier wrote to his friend, the poet Pontus de Tyard: "Si je ne m'abuse, vous et moy restons presque seuls en cette France de cette belle brigade, que produisit le regne du Roy Henry II" (Oeuvres, II, p. 462). ("If I am not mistaken, you and I are about the only ones left in France of this beautiful brigade produced by the reign of King Henri II"). ${ }^{67}$ A medal of Pasquier's was engraved in 1605 (five years before the publication of Les Jeus Poétiques) and represented him as the Gallic Hercules dragging people by his tongue. The image referred to Pasquier's rhetorical gift as a brilliant lawyer, but any learned contemporary would have caught the allusion to Henri II's royal entry into Paris in 1548. The evocation of the Gallic Hercules had been part of this ceremony. A mention of the god of French eloquence famously reappeared a year later, at the end of $\mathrm{Du}$ Bellay's La Deffence et illustration de la langue françoyse (1549), the "manifesto" of the future Pléiade. 68

When preparing his collection, Pasquier surely had in mind the example of the aged Ronsard gathering his earlier publications in successive editions of his complete works. Ronsard had conceived his Oeuvres as an immortal poetic monument; likewise, Pasquier's Les Jeus Poétiques was the product of a theatrical culture. Both authors carefully revised their previous texts and organized them in meaningful ways. By dialoguing with their own literary productions, they capitalized on their capacities to make and remake themselves, to resist the social constraints and imperatives imposed upon old age.

In the address to the reader prefacing his collection, Pasquier claims to present his own love affairs, but in reality, each section of Les Jeus Poétiques creates the effect of a collective discourse on love by elaborating on impersonal, stereotyped amorous behaviors at different ages of life. The first section, "Loyaulté," presents the poet lover as a "young man in the age of innocence" (p. 105). Since this part contains the greatest number of the author's earliest verses, it is not surprising to find conventional Petrarchan conceits and imagery. The lover finds himself a prisoner of a beautiful and cruel lady, after love's fatal glance comes the standard description of the physical and moral perfections of the beloved. The

67 The Brigade was the first "incarnation" of the Pléiade.

68 Joachim Du Bellay, La Deffence et Illustration de la langue françoyse, ed. Jean-Charles Monferran (Geneva: Droz, 2001), p. 45. 
young lover worships his lady, but his efforts to seduce her remain vain; his obsessive passion becomes a source of frustration and torture. All the Petrarchan paradoxes so fashionable in the love poetry of the 1550 (the icy fire, the darkness of light, and so on) are present to express his contradictory feelings. Half a century later, Pasquier was fully aware that many aspects of this rhetoric seemed outdated. His Jeus Poétiques reassessed the tone of his youthful verses, stressing the ridiculous figure cut by the young poet lover of "Loyaulté." These verses, the old poet now declares to the reader, were written with tongue in cheek, and should be read accordingly: "En un mot je laisse au grand Petrarque pour closture de ses amours, un long repentir" (p. 106). ("In a word, I leave to the great Petrarch, as closure to his loves, a long repentance.") He also mocks the poet Tasso for going mad over his unrequited love for the Princess of Ferrara (p. 106).

Already in 1553 the fashion had begun to turn away from the Petrarchan representation of the faithful lover. Ronsard sarcastically accused Petrarch of playing the transfixed lover (I, pp. 168-69). Intent as ever on inscribing his own career into the poetic record of his time, Pasquier reacted in a similar way in 1555 and questioned the sincerity of Petrarch's passion, as well as that of his numerous imitators (Oeuvres I, p. 145). In "Liberté," the second section of Les Jeus Poétiques, he adopts the posture of the inconstant lover championed by Ronsard. Some poems in "Liberté" also mention Du Bellay and Tyard (Sonnet 13), members of the Pléiade. This section incorporates poems published in 1555 and 1578 , and is a compendium of commonplaces on youthful lovers who turn women into objects that they long to possess.

Despite this blending of lyrical voices, Les Jeus Poétiques is not the work of a dilatory and servile imitator, but rather of a lawyer well equipped to give rhetoric a central place in the creation of his "roman d'amour." Each section of the collection contains the seeds of the next ones and demonstrates Pasquier's versatility in his self-casting as a lover. "Loyauté" focuses on the young and inexperienced lover's obsessive passion for a single woman; "Liberté," in contrast, depicts a more mature protagonist who is determined to enjoy every opportunity for love affairs because nothing is permanent. Whereas "Loyauté" elaborates on images of entrapment in the labyrinth of love, "Liberté" focuses on instability as a general principle governing human behavior, and the world as a whole. The third section, "Ambition," complements Pasquier's catalog of amorous behaviors by playfully adding a new character to the repertoire of French love poetry. The protagonist, now in middle age and married, has adopted the identity of a successful lawyer. He climbs the social ladder and concentrates on a 
professional career which leads him away from love. His lust for money, glory, and fame echo many of Ronsard's poetic concerns, but these motives now strike an ironic note since they appear as part of adulthood's bourgeois pragmatism. The section concludes with an elegy spelling out a husband's and a wife's respective duties for living peacefully, and expresses concern for the couple's future children (pp. 314-16).

As he reaches old age, the protagonist falls in love again. The fourth section on "La Vieillesse Amoureuse" ("Old Age in Love") challenges the idea that individuals do not revert to earlier stages. Wounded by Cupid's arrow, the aged lover shows every sign of the youthful passion seen in "Loyauté." The old man in love is a comic figure per se, much present in the French comedy of the period, and Pasquier's own Pastorale du Vieillard Amoureux was a witty contribution to this genre. Yet, to limit the interest of "La Vieillesse Amoureuse" to its comic potential would be to give little credit to its creative energy. Like Ronsard's Sonnets pour Hélène, this section ironically revisits the powerful Petrarchan model of love poetry. Both Ronsard and Pasquier find new resonances from their earlier Petrarchan poems. In Ronsard's poems to Hélène, for instance, the lover alleges that his beloved's gaze rejuvenates him, and playfully questions the benefits of this change:

Quand tu as reverdy mon escorce ridée

De ta jeune vertu, ainsi que fit Medée,

Par herbes et par jus le pere de Jason,

Je n'ay contre ton charme opposé ma defense:

Toutefois je me deuls de r'entrer en enfance,

Pour perdre tant de fois l'esprit et la raison (II, S 40, ll. 9-14, p. 399)

When you restored youth to my wrinkled bark with your youthful virtue, just as Medea did for Jason's father with herbs and juices, I did not defend myself against your charm: and yet I am distressed to reenter childhood, losing my wit and my reason so many times. ${ }^{69}$

In a similar way, Pasquier reinforces the fated nature of the aged lover in "La Vieillesse Amoureuse" by parodying the first section of his Jeus Poétiques. Both sonnets I and II, for instance, echo the young and inexperienced lover's innamorento in "Loyauté." Ardent in his desire, heedless of the consequences of his passion, the aged lover shows no sign of the stereotypical prudence and wisdom of old age. His reason fails to resist being attracted to sensual pleasure. Circling back to second youth, he puts

69 My translation. 
his beloved on a pedestal, but is lucid enough to appreciate the absurdity of his passion. Absurd as his love may be, it is a process of self-discovery, a whole reassessment of the aged lover's sense of identity.

Other aspects of Pasquier's story of love in old age ironically echo Petrarch's passion for Laura in his Canzoniere (to which Ronsard also referred in his Sonnets pour Hélène). Like Petrarch's beloved, the lady falls ill, then ages faster than her older lover, and becomes like a "repulsive carcass" (S 15). A lawyer by profession, Pasquier adds a smiling judiciary touch to this satirical portrait: on her deathbed, the lady makes her will and donates her wealth to the old poet lover $\left(S_{17}\right)$. The section ends with a game about words: two songs present arguments for and against a love relationship between an old man and a young woman. The aged lover concludes by saying that he does not tell the truth either when he claims to love the young lady or when he pretends not to love her. His statement immediately prompts a response from her: she mocks his rhetorical subtleties and says that when it comes to love, no old man can be taken seriously (pp. 337-42).

Throughout the Jeus Poétiques, the self is a dynamic multiplicity of relatively autonomous "I" positions in an imagined landscape. The division of the collection into ages stresses the provisional and fragmentary nature of the individual subjects while also suggesting the dependence of the subject's identity on a web of social relations. Each "I" has a story to tell about its experiences from its own standpoint. By and large, the poems gathered in the two sections on old age had not been published previously; they were the work of an octogenarian author who had firsthand knowledge of this stage of life. In "La Vieillesse Rechignée" ("Grumpy Old Age"), the final section of the collection, Pasquier elaborates on yet another set of commonplaces on old age which Ronsard had explored before him. As he reaches the stage of decrepitude, the protagonist of Les Jeus Poétiques becomes disillusioned about love. He has become an unattractive, impaired, and socially dysfunctional person. Even worse, he appears as a narcissistic and selfish man who finds everything in the world displeasing, including himself, and longs for death to deliver him from his wretched life (p. 364).

Yet discouragement and despair are not the final words of this éducation sentimentale on life's stages. Instead, the octogenarian Pasquier ends his collection by playfully praising the pleasure of illusions, and his own wit:

De l'Amour je me mocque, et encores de moy,...

Et voiant que ce Tout n'est rien que vanité,

Bien vivre, et m'esjouir c'est ma Philosophie. (p. 370). 
I make fun of love and also of myself...

And seeing that everything is but vanity,

Living well and rejoicing is my Philosophy.

When confronted by the mutability of both human existence and rhetorical fashion, Pasquier offers neither resignation nor acceptance, but rather the ability to respond imaginatively to the passage of time, with a smile. Today's gerontologists observe that as we grow old, we have a greater capacity to appreciate the multiple levels of our stories, the multiple characters within them, the multiple selves that tell them, and the multiple interpretations of the events that make them up. And we also acquire a greater capacity to laugh at our lives in a detached yet affectionate manner. As Pasquier's dual representation of love in old age makes clear, multiple versions of a person's life can be woven around the same basic set of facts. ${ }^{70}$ At age eighty-one, Pasquier knew he was approaching the end of his life, but joyfully pretended to forget his age. Even for an octogenarian, there was the prospect of opening up a new chapter.

As he watched himself growing old, Pasquier learned to enjoy what he had without clinging to it. This, in turn, meant that he could not only increase his chances of experiencing joy but increase the chance that the joy he experienced would survive changes in a world where everything is short-lived and perishable. In George Bernard Shaw's words, "We don't stop playing because we grow old, we grow old because we stop playing."71 Play was the very sign of the wisdom he had acquired during his long life. Like Montaigne and Ronsard, he confronted age stereotypes but did not challenge social decorum and convenances. Throughout Les Jeus Poétiques, love is a poetic experience that is less about having certain ends in mind than about coming to terms with new beginnings.

If love is a game, poetry is another, more serious kind of play. Les Jeus Poétiques was conceived as a social entertainment for the learned guests of the French salons, but its playful tone did not prevent its author from dreaming of literary fame. No author is able to predict which one of his works will survive the ravages of time, Pasquier notes in his address to the reader; sometimes posterity gives a stamp of approval to a few lines that

70 Gary Kenyon, E. Bohlmeijer, and W. L. Randall, Storying Later life. Issues, investigations, and interventions in narrative gerontology (Oxford: Oxford University Press, 2011), pp. ix-x. See also Randall and McKim, Reading Our Lives. The Poetics of Growing old, pp. 161, 281, 217-21, 236, 240. Whether the "self" is behind these various masks, or among them, is beyond the scope of this study.

71 Cf. http://beliefnet.com/Holistic-Living/index.aspx. Accessed March 14, 2013. 
were written just for fun, while the text that its author most values may go unnoticed and sink into oblivion. He then adds: "Quel sera le hazard de mes Jeus Poétiques (ainsi me plaist-il les nommer) je ne m'en donne pas grande peine." (p. 105) ("What will be the fate of my Jeus Poétiques (as I like to call them), I don't really care"), One may, however, question the sincerity of this statement since in a letter to his friend Antoine Loisel he wrote: "et peut-estre adviendra-t-il que celles [mes oeuvres] dont je fais moins de compte seront les mieux recueillies" (Oeuvres II, p. 282) ("and maybe it will happen that those of my works I value the least will be best received." $)^{72}$

In reentering the social stage with a collection of love poetry at age eighty-one, Pasquier was aware of the gamble. He who had been ahead of his time as a member of the Pléiade in the 155 os now fell back upon the role of witness, passing his experiences on to new generations of poets. What he wanted to pass on to his successors were the arts of detachment and discernment. Both had poetic implications. What are the broader consequences of his acute and compassionate observation of human comedy? If we consider that our age is an integral part of our identity, we must also recognize that our age is also frequently in potential tension with our identity. We subjectively cling to an image of ourselves as unchangingly young. While our mind may support this phenomenological sense of coherence and continuity, our body's external appearance belies this image. ${ }^{73}$ Like Petrarch, Ronsard, and Montaigne, Pasquier used stereotyped and abstract accounts of the stages of life to promote a much more varied notion of love in old age as both a social and a literary process.

\section{Conclusion}

The self-portraits discussed in this chapter reveal something about the perception of old age in their respective writers' social groups. Despite their resistance to widespread stereotyped views on the winter of life, the dual portrait of the lustful old man and the chaste old man did not disappear. By the end of the sixteenth century, both representations still

72 This remark predated the publication of Les Jeus Poétiques, but Pasquier kept thinking of the enduring fame of the Decameron, a work that Giovanni Boccaccio did not consider his masterpiece (Oeuvres II, p. 282).

73 On this notion, see M. Featherstone and A. Wernick, Images of Aging: Cultural Representations of Later Life (London: Routledge, 1995); S. Biggs, "Choosing not to be old. Masks, bodies and identity management in later life," Ageing and Society 18 (2007), pp. 209-21. 
permeated every field of Renaissance arts, science, and letters. Among countless examples in literature, in his posthumous defense of old age De bono senectutis (1597), the cardinal Gabriele Paleotti links old age to serenity, while associating youth with sexual appetite. Likewise, in his Sage vieillard (1606), the French protestant Goulart praises the old man's traditional wisdom and reason, and equates love in old age to Christian caritas and preparation for the afterlife. In a less assertive way, Guicciardini notes that from his forties on, a man should remember that youth is under the sign of Venus, and that old age is associated with Saturn. These planets, he adds, are in opposition to each other ("l'una dall'altra molto contraria"). ${ }^{74}$

Stereotypes confirm the notion of a stable and universal life cycle with recognizable stages, but the representations described in this chapter confounded these abstract constructions. Aging ceased to be understandable in terms of any common or totalizing experience. It was no longer a fixed and homogeneous process, but rather a complex experience expressed in a variety of ways and viewed from different perspectives. The self-portrait of the writer as an elder in love gave Petrarch, Montaigne, Ronsard, and Pasquier the opportunity to choose a variation promoting their own uniqueness.

${ }^{74}$ Niccolo Guicciardini, L'Ore di ricreazione, ed. A.-M. Van Passen (Rome: Bulzoni, 1990), p. 283 . 


\section{THEN AND NOW}

Foucault's research may be historical, but it is aimed at our time. By pointing out aspects of the present that confine us, it seeks new potentialities by discussing texts from other centuries. "What I am trying to do is provoke an interference between our reality and the knowledge of our past history," Foucault said in an interview. ${ }^{1}$ By "disturbing" and fragmenting our linear understanding of history as a continuous progress, he attempted to provide a basis for a transformative and emancipatory knowledge of society. Our present problematic is both what shapes his study of the past and that which arises out of his historical work, yet he consistently refused to prescribe or legislate for the future. His line of inquiry opens itself up to periods that he hardly studied and to issues that he did not investigate at all, thereby underlining the vitality of his legacy.

Indeed, where are we today and why should we ignore the account of past experiences of later life? What can we learn from Renaissance stories of later life? We cannot blindly reapply their practices for taking care of the aging self, but it does not mean that their remarks cannot produce something new. The point is to think about their ways of acting against time (and thus on time) in new contexts and in other situations. Despite advances in technology, medicine, and standards of living, the ways we adjust to increasingly difficult age-related changes have not varied much over the centuries. Strategies differ from person to person depending on circumstances, but unlike the history of sciences, the history of coping with the effects of time on our bodies and minds is not one of straightforward progress.

Far from being obsolete, stories of later life from Petrarch's and Montaigne's times can guide us in negotiating our relationships to ourselves, the world, and others. We see these texts as critical reflections on, and literary transformations of, old age, but they can also bring desirable

\footnotetext{
1 Michel Foucault, "Truth is the Future," interview with M. Dillon, November 1980, in Foucault Live: Collected Interviews 1961-1984, ed. Sylvère Lotringer (New York: Semiotext(e), 1996), p. 301. See also The Final Foucault, ed. James Bernauer and David Rasmussen (Cambridge, Mass:, MIT Press, 1988), p. 10. 
changes in the way we live now. Their pragmatic modes of articulating selfknowledge, in particular, deserve closer scrutiny. The writers consulted did not necessarily have all the answers or the "right" way of addressing the problem of aging gracefully; the past does not have ready-made solutions for the present, but it can provide a basis for revisiting current issues. Continuity and change go hand in hand, in this respect: to some extent, every literary representation of graceful aging is a form of bricolage that involves adaptations of previous texts to a personal story in a specific historical context. Renaissance self-portraits in later life are no exception. Reading them invites us, once again, to reweave our collective cultural past into the present.

In what follows I will examine these evolving attitudes in the dynamics of time, and will discuss three types of connections between "then" and "now." First, an ambitious research project from the end of the twentieth century, focusing on the care of the aging self, allows us to think about health issues in a diachronic perspective. Second, we will analyze the heuristic function of Erasmus's colloquium The Old Men's Chat or the Carriage and see how this text opens itself up to spiritual, social, and psychological perspectives on the aging process that are still relevant today. Third, Petrarch's and Montaigne's self-portraits in later life provide us with further insights on the aging self's multiple identities. If aging gracefully is a way of life that capitalizes mostly on Epicurean and Stoic attitudes toward time, it is also a mode of discourse; Montaigne's Essais are a brilliant illustration of narrative tactics.

\section{The Care of the Aging Self}

In 1984 the John D. and Catherine T. MacArthur Foundation funded a study to develop the conceptual basis of a "new gerontology" focusing on life satisfaction and personal health. In reaction to gerontologists' preoccupation with disability, disease, and chronological age, the project intended to pinpoint "the many factors that conspire to put one octogenarian on cross-country skis and another in a wheelchair." ${ }^{2}$ Sixteen scholars from disciplines relevant to aging (including sociology, epidemiology, genetics, and biology) individually researched "the many factors which permit individuals to continue to function effectively, both physically and

2 John W. Rowe and Robert L. Kahn, Successful Aging (New York: Pantheon, 1998), p. xii. Further references are incorporated into the text. 
mentally, in old age" (p. xii). The investigations ranged from studies on the daily life of over 1,00o high-functioning elders to genetic analyses of hundreds of pairs of Swedish twins, laboratory-based research, and examination of brain aging. While acknowledging the difficulty of defining "usual" physiological decline, the researchers focused on the move from "normal" aging to higher levels of functioning, seen as "successful aging." By gathering data on the changes in American society that would enable more men and women to age successfully, the study aimed at presenting new conceptualizations of later life. Hence it was part of a broader attempt to eliminate prejudices toward old people. ${ }^{3}$

In the final report, published in 1998, John W. Rowe and Robert L. Kahn underscore the need to discard six stereotypes or "myths" about old age and longevity. First, they unmask the presumption that "to be old is to be sick," and observe that even if rates of chronic illness and disability increase in later life, a substantial number of seniors adapt to their physical limitations and live independently in their own homes. Second, they criticize the widespread assumption that "you can't teach an old dog new tricks," because neurobiology demonstrates that the human brain retains its ability to learn new things into advanced age. Third, they object to the idea that poor lifestyle choices should not be altered because the damage cannot be reversed, and point to data showing that lifestyle changes may delay disabilities well beyond middle age and reduce the need for long-term care. Fourth, they question the belief that the secret to successful aging is to "choose your parents wisely," noting that genetic factors play a smaller role in old age than they do earlier in life. Fifth, they reject the view that older people are unproductive and do not contribute to social welfare. And finally, they challenge the contention that seniors lack sexual interest, attraction, and performance ability. In reaction to the prevailing narrative of old age's physical frailty and decline, Rowe and Kahn observe:

The notion that we can attain high-quality, vital, disease-free later years is a novel one. Even recently, it would have seemed paradoxical to discuss health promotion and disease prevention in the elderly. (p. 66)

Needless to say, the conceptual framework of the MacArthur Foundation's project has nothing in common with Galen's medical and cosmic views

3 These attempts started in the late 1960s. See Thomas R. Cole, The Journey of Life. A Cultural History of Aging in America (Cambridge: Cambridge University Press, 1991), pp. 227-39. 
on aging. Its methodology and analyses would have been inconceivable in the Renaissance. How ironic then, that the MacArthur Foundation spent over ten million dollars to rediscover practices familiar to Petrarch's and Montaigne's contemporaries, and even to Galen's. The 1984 project expanded the perception of older people as healthy, self-reliant, productive, and sexually active. Just as in the Galenic health regimens discussed in chapter 1 , individuals are expected to take prime responsibility for maintaining their own well-being throughout adult life. Echoing Galen's De Sanitate tuenda, the MacArthur report asserts that older people have significant abilities to prevent illnesses, to minimize losses in physical and mental function, and to enhance their engagement in life. Since each individual has an impact on the quality and the length of his or her life, the report provides simple ways to keep a sound mind in a healthy body. Every single recommendation of the MacArthur team confirms observations made by Galen and his followers: exercise regularly, eat nutritiously, maintain close social relationships, and stay involved in meaningful and purposeful activities that enhance mental acuity. ${ }^{4}$

Well before the MacArthur project, the writers under consideration in the previous chapters discussed the process of growing old in terms of lifestyle. By lifestyle, I mean a "more or less integrated set of practices which an individual embraces, not only because such practices fulfill utilitarian needs, but because they give material form to a particular narrative of self-identity." 5 Yet while from one century to another the words and the processes to which they refer may be the same, their meanings do not necessarily coincide; whether we are aware of them or not, cultural beliefs and social values shape our understanding of and approach to aging. One obvious shortcoming of the MacArthur project is its failure to take into account the fact that subjective experiences-including the experience of growing old-have their own cultural and social historicity. The report elaborates on the potential for a healthy and satisfactory later life but does not investigate the wider intellectual and social context necessary for realizing success. On the one hand, the confrontation between "then" and "now" points to what might be universal across time and place in adjusting to aging-related issues; it highlights a stock of basic images, ideas, fundamental wishes, fears, and beliefs about the temporal nature

\footnotetext{
4 See chapter 1, the section on Galen.

5 Anthony Giddens, Modernity and Self-Identity. Self and Society in the Late Modern Age (Stanford: Stanford University Press, 1991), p. 81.
} 
of human life. On the other hand, comparing experiences from different time periods reminds us that universal problems only have historical answers rooted in a specific context.

Yet in spite of-and somehow because of-the differences between "then" and "now," Renaissance stories of later life such as Erasmus's colloquium The Old Men's Chat or The Carriage open themselves up to a dialogue across time. At stake are social, spiritual, and psychological perspectives that point to the need for knowing oneself. What matters is not just the meaning of successful aging but how individuals respond to the process of growing old.

\section{Erasmus's Colloquium “The Old Men's Chat”}

First printed in the March 1524 edition of Erasmus's Colloquies, The Old's Men Chat or The Carriage stages a reunion of friends who have not seen each other since their university years in Paris, forty-two years previously. ${ }^{6}$ They meet by coincidence while waiting for a cart to take them to Antwerp's fair, and decide to hire a carriage for the four of them in order to exchange stories of their respective lives. The metaphor of the journey of life is transparent. The "device of bringing elderly men together to examine... the variety of human experiences and values is ancient and familiar," Craig Thompson observes; ${ }^{7}$ following this pattern, each of the four old men epitomizes certain virtues and vices related to the temporal nature of human existence.

Throughout the dialogue, the disparities of the protagonists' respective lifestyles render impossible any global perspective on old people; far from being a homogenous group linked by common physical frailties, behaviors, and reactions, Erasmus's protagonists represent four distinctively different ways of growing old. Glycion ("agreeable," "delightful") is sixtysix years old and seems not to have aged at all. He has all his teeth, no wrinkles, not a single white hair, and a beautiful complexion. His youthful and serene look is the result of healthy daily habits and principles of moderation. He carefully chose a good and loving wife for the sake of offspring,

6 In some sixteenth-century editions, the text is entitled Senile Colloquium. Erasmus, Collected Works. Colloquies, ed. and trans. Craig Thompson (Toronto: University of Toronto Press, 1997) vol. 39, pp. 449-67. All further references are taken from this edition.

7 C. Thompson, preface of The Old Men's Chat, p. 448. 
became a widower after eight years of happiness, and remained single to dedicate himself to his four children. His professional life strikes the same note of prudence and common sense. He holds a respectable public office that gives him no trouble, and has a good income and the financial means to assist his friends. He is generous, kind, esteemed by his fellow citizens, and has no enemies. When asked how he managed to stay in such good shape, he answers in true Galenic spirit that he closely monitors his diet, does not overwork himself, and takes good care of his body and mind. He also frequently leaves the city to relax in the green and peaceful atmosphere of his country house. During his leisure time, he enjoys listening to music and reading books.

In contrast to Glycion, his friend Polygamus looks extremely old. As indicated by his name (poly gamos, "much married"), his numerous unions have taken a toll on his life. His unrestrained sexuality ruined his health and affected his professional career. Given his lavish lifestyle, he had to change "from a student of the seven liberal arts into an artisan with one art" (p. 455) to cover his debts, and is still struggling financially to raise his many children. He judges himself lucidly, but confesses his inability to reform his life. In fact, he is ready to marry again - for the ninth time-if there is any opportunity.

Pampirus's life was even more unstable than that of Polygamus. His father gave him a sum of capital to get a good start in trading, but he lost everything by gambling. When his father disinherited him, the parents of the beautiful and wealthy girl he was courting broke the engagement. As his name suggests ("Jack-of-all-trades"), Pampirus knocked about the world. In despair after losing his bride, he became a monk, traveling extensively and joining one religious order after another. He went to the Holy Land and came back worse than before his pilgrimage. He lived by his wits much of the time; at one point he lived by reading palms; later he enrolled in Julius II's army when the pope waged war against France. In contrast to Polygamus, however, he learned his lesson. He came back home, took over his father's business, and settled down.

The fourth man had a much quieter existence. Eusebius ("dutiful," "pious") studied medicine and theology in Padua for four years and was deliberating over the choice of a career when a church living with an ample income came his way. He accepted it, and now lives in a house next to the church. He has neither striking qualities nor dangerous vices, and although he is a clergyman, he has no deep religious feeling.

The dialogue ends abruptly with an unexpected epilogue: the coachman tells a coworker that these old men are nice because they gave him 
a good beer three times along the way. "Ah, ah! They're good to you, anyway," the other coachman replies (p. 461).

In The Usefulness of the "Colloquies"(De Utilitate Colloquiorum), Erasmus stresses the moral perspective of The Old Men's Chat:

how many things are shown, as though in a mirror, that should be avoided in life or that render life serene! Better that young people learned these from pleasant chats than from experience. Socrates brought philosophy down from heaven to earth; I have brought it even into games, informal conversations, and drinking parties. For the very amusements of Christians ought to have a philosophical flavor. ${ }^{8}$

The reference to Socrates directly echoes a remark by Cicero in his Tusculan Disputations: "But Socrates was the first who brought down philosophy from the heavens and, snatched from the stars, forced it to live on earth among men, and to deal with morals and the affairs of men." $(5,4)^{9}$

What exactly should "young people" learn from The Old Men's Chat? Obvious possibilities are how people construct their lives and make sense of aging. Throughout the dialogue, there is the expectation that individuals should take responsibility for achieving and maintaining health, emotional well-being, wealth, and a respectable social position. For each protagonist, old age is the final reckoning of how well such responsibilities have been met. The respective accounts of Pampirus and Polygamus constitute an unequivocal warning. Polygamus is the caricature of the Epicurean who destroys himself in hedonistic pleasures. His story is a reminder that youth is not eternal, and that lust is a dangerous and self-destructive sin. Pampirus, on the other hand, wasted his life because he failed to make it meaningful. As indicated by his name, he tried everything, and had no clear goal in mind; he misused his time and energy in pointless travels and sporadic activities without attempting to introduce unity into it. He lacked the power to examine and discriminate the various contents of representations. He was interested in religion but had the wrong conception of faith. In contrast to the Christian soldier in Erasmus's Enchiridion militis Christiani, Pampirus did not dedicate his life to Christ, but was fascinated by the monks' colorful clothes and by the beauty of rituals, without understanding their true meaning. Likewise, he went to the Holy Land not to be closer to God but because he found the notion of pilgrimage

8 "The Usefulness of the Colloquies", in Erasmus, Collected Works. Colloquies, vol. 40, ed. and trans. Craig Thompson (Toronto: University of Toronto Press, 1997), pp. 1102-3.

9 Thompson fails to note this reference in his critical edition of Erasmus's Colloquies. 
attractive. He is the incarnation of the literal-minded faith in mere formalities and decorum. Following Saint Paul's epistles, Erasmus sees these external constraints as antithetical to genuine piety and Christian liberty. Throughout his life, Pampirus focused on superficial matters rather than on the spiritual function of religious ceremonies. In addition, he served Julius II, whom Erasmus criticizes elsewhere for his secular ambitions and lack of piety.

If the lives of Pampirus and Polygamus are cautionary tales, might one of their companions be a role model for the young reader Erasmus had in mind when writing this colloquium? Certainly not Eusebius, whose name ("pious") ironically points to his lack of piety. Eusebius epitomizes the lust for material comfort and benefits, and the lack of devotion evident in many members of the clergy. For Craig Thompson, it is Glycion who embodies Erasmus's conception of a good life, since this character's opinions “are consistently like Erasmus' own." In Thompson's view, Glycion “is a decent, proper Christian who in practical affairs observes the Horatian mean and exemplifies common sense." 10 He has a happy family life and a respectable career; he lives in harmony with himself and with the world; he is keen to express his appreciation for life. As shown by his excellent physical and intellectual condition, Glycion's old age is in fact an extension of his middle age. It is true that Glycion had an "honest" and successful life (although a rather dull one, according to Pampirus, p. 453), yet I question that he represents Erasmus's ideal, as Thompson argues.

In my view, the colloquium does not propose a model for an exemplary and successful life. Rather than presenting guidelines that the reader should mechanically imitate, the text acts as "a mirror," to borrow Erasmus's own words (De Utilitate Colloquiorum, p. 1102). As stated in the Usefulness of the Colloquies, The Old Men's Chat has a pedagogic goal: it invites the reader to examine his own life in the light of a conversation that he has the illusion of overhearing. Erasmus expected his dialogue to generate a discussion on issues such as how to age gracefully and how to define a successful and happy life; in short, he anticipated his reader's personal reactions to the four old men's stories. By capitalizing on the audience's involvement and judgment, the colloquium invites the reader to weigh his priorities, his values, and the consequences of his actions; it urges him to get rid of bad habits if, like Pampirus and Polygamus, he has taken the wrong path. The dialogue's abrupt end confirms this interpretation since,

10 Introduction to The Old Men's Chat's English translation, p. 448. 
as the coachman's final comment puts it, the four old men's stories are "good to $[u s]$ " - as readers-because rather than offering an unequivocal answer to the question of "how to live," they force us to think about our own way of growing old. As always in Erasmus's pedagogical texts, one should live according to one's principles: in his own words, "men are not born, they become" ("homines non nascuntur, sed finguntur") through persistent efforts to improve. ${ }^{11}$

Only the living word-a conversation-can accomplish this goal. Not surprisingly, in the Usefulness of the "Colloquies," Erasmus situates The Old Men's Chat in the tradition of Socratic dialogues. Like Socrates's conversations, this colloquium is an exercise that invites the readers (or listeners) to find the solutions they need by themselves. For Socrates, knowing oneself is the prerequisite to finding a valuable answer to any question concerning the self. Similarly, Erasmus's colloquium stresses the path the reader traverses with the four old men, without giving a definitive "recipe" for aging gracefully. Keeping in mind the metaphor of the journey of life that underlies the colloquium as a whole, Erasmus hopes that his readers will be better travelers than the four protagonists. Not surprisingly, Erasmus intended his dialogue to be read by a young reader, because people in the prime of life need to anticipate the inevitable effects of time on themselves. The four old men's stories teach their young, inexperienced readers that life choices are invariably aging-issues, since they have longterm implications. The expectation that the reading of this text will trigger a process of self-realization and improvement implies a belief in the freedom of the will. This belief takes its full meaning in Erasmus's pedagogical perspective.

Any reader familiar with Erasmus's Christian philosophy, with its blending of Christian and classical—especially Stoic—references, cannot fail to notice that spiritual concerns are conspicuously absent from the four old men's stories. As a text such as the poem Carmen Alpestre makes clear, for Erasmus, following Christ is the true measure of the "success" and satisfaction of a human life. ${ }^{12}$ Yet the four old men behave like those busy people whom Seneca (one of Erasmus's favorite authors) ridicules in De Brevitate vitae (III, 4-5); despite their age, they forget that they are mortal, and seem indifferent to the afterlife. In fact, they do not think at all about salvation. Eusebius and Pampirus have (or had) connections

11 Colloquium religiosum, Collected Works, vol. 40, p. 421.

12 See chapter 1, the section on Erasmus. 
with the Church, but show no sign of true devotion. For the reader, might God's absence in the protagonists' lives suggest that the true business of growing old is a movement toward the spiritual rather than the pursuit of good health, financial security, and a happy family life, as exemplified by Glycion? For Erasmus, only death reveals the true value of an individual's life. In his view, our effort to live according to religious and ethical principles is the prerequisite for our hope of salvation.

From the Renaissance to the present day, similar aspirations are expressed in different ways within specific cultures and discursive formations. While twenty-first-century Westerners may not occupy the same situations as the colloquium's protagonists, we can still recognize and understand them. Detached from its historical context and considered in its most profound meanings, The OldMen's Chat forces us to reexamine our values and behavior. Social gerontologists note a tendency in our Western culture to deprive old age of ethical and spiritual meaning. In his study on aging in the United States in the nineteenth and twentieth centuries, Thomas R. Cole describes "a historical evolution from communal ideals of transcendence through societal ideals of morality to individual ideals of health."13 Our consumer society has promoted and capitalized upon an obsession with youth and physical appearances, manifested in the sale of products and techniques ranging from vitamins and anti-aging creams to cosmetic surgery. Health in later years has become a business that requires a complex and heterogeneous set of apparatuses ("dispositifs," in Foucault's term) regulating space, medical, and administrative questions, etc. Today's elder Westerner from the upper or middle classes cannot be accused of neglecting himself, yet Foucault's criticism of the "modern" man is fully relevant here: in many ways, the forms of the elder's attention to himself, combined to the priority of scientific knowledge about aging, preclude a practice of care of the self as a practice of freedom. In reaction to this trend, today's proponents of "conscious aging" direct our attention to practices of self-transcendence drawn from religion and art. ${ }^{14}$

Although written in another social and cultural context, The Old Men's Chat invites us to move from the view that growing old is something that "happens" to us toward recognizing it as an experience with which we must engage. The colloquium urges the reader to concern himself less

13 Cole, The Journey of Life, p. xxx.

14 Harry Moody, "Productive Aging and the Ideology of Old Age", in Productive Aging. Concepts and Challenges, ed. Nancy Morrow-Howell, James Hinterlong, and Michael Sherraden (Baltimore: Johns Hopkins University Press, 2001), pp. 175-95. 
with what he has than with what he is, to think about how he spends his allotted time, and about the direction his life takes. Echoing classical and Christian values, it reminds us that fame, possessions and power are not sources of lasting fulfillment, and that our attention should focus inward. To continue to activate this experience, we have to remain constantly aware of our current situation, and to keep searching for practices that respond to the dangers and the needs of the present. Practices and discourses related to the care of the aging self arise as concrete responses to concrete problems, hence none of them can be seen as definitive and universal. Therefore, the art of aging gracefully has to be seen in a dynamic perspective.

Foucault observed that Western "technologies of the self" are more diverse and fluid today than in the distant past, and I would add that an increasing number of people are now in a position to act out those choices. Renaissance stories of later life can help us problematize these choices. Despite differences in context and culture, texts such as The Old Men's Chat already represented aging as a heterogeneous experience and questioned the concept of old age as a distinct stage of life, with a fixed set of characteristics. It is this fragmentation of a highly socialized biological process that makes growing old such a key feature of Erasmus's, Petrarch's and Montaigne's time as well as of our present-day Western world. The acceleration of this fragmentation is a major feature of our twenty-firstcentury society, as reflected in the observation by Christopher Gilleard and Paul Higgins that "what has emerged is a variety of potentially competing cultures of aging."15

In addition, Erasmus's colloquium raises issues directly relevant to us that its author and readers could not have anticipated. Despite their age, all four protagonists are professionally active-not surprising since the notion of mandatory retirement was unknown in the sixteenth century. In contrast, today we read endless reports about the economic and social implications of an increasingly older population. This is part of a broader generational equality debate that was unconceivable in Erasmus's time, and stems from a current desire to raise the status of older persons as contributors to the collective welfare. On the one hand, age-related health issues are highlighted in the press because they impose growing demands upon the state. On the other hand, social gerontologists note a broaden-

15 Christopher Gilleard and Paul Higgs, Cultures of Ageing. Self, Citizen and the Body (Edinburgh: Pearson Education, 200o), p. 8. 
ing of work opportunities for later life. ${ }^{16}$ Proponents of "productive aging" try to counter concerns about the burden posed by an aging population, arguing that older people who work for a salary participate in economic growth. Likewise, seniors who are involved in volunteer activities are praised because their work benefits their communities. In many ways, the "productive aging" arguments embody the American values of individual success and social engagement: by giving back to society, older people contribute to their own growth.

Debates on old age are taking center stage in today's social sciences, yet the focus on aging is often constructed out of "other" processes (unemployment, health care, retirement, pensions) and not considered as a lived experience of individuals seeking a satisfying later life. Medicine is not the only area where aging bodies are discussed; a concern for them also permeates political and economic thinking. ${ }^{17}$ In Erasmus's Old Men's Chat, the notion of aging gracefully does not have such wide range of implications, but is a common arena for evaluating personal and social behaviors, religious and moral values. Furthermore, Erasmus's Old Men's Chat offers a perspective that transcends modern social policies and medical interventions: belief in the therapeutic value of reviewing one's life. Given its pedagogical orientation, the dialogue seeks to convince its readers that self-examination generates new beginnings at any age. Erasmus's views had Stoic and Christian sources, yet the implications of narrative gerontology continue to be explored today. In their Practitioner's Guide, Jeff and Christine Garland assert that a review "gives direction to people's lives as they move towards a valued endpoint, along a well-trodden track marked by success stories - and failures."18 Beyond a thorough life review, there are other, more fragmentary and less analytical ways of evoking the past, allowing for a more flexible and mutable perspective on the self. ${ }^{19}$ Regardless of format, however, the Garlands assert that the "storying" of one's life has a "multifaceted role":

to aid the narrator in achieving new insight and peace of mind; to bring closure to troubling events from viewing them from a different perspective, to restore as far as possible neglected skills or abilities (p. 4)

16 Ibid., pp. 1-7.

17 Ibid., p. 7 .

18 Jeff Garland and Christina Garland, Life Review in Health and Social Care: A Practitioner's Guide (Philadelphia: Brunner-Routledge, 2001), p. 35.

19 See Kathleen Woodward, "Telling Stories: Aging, Reminiscence, and the Life Review," Journal of Aging and Identity 2, 3 (1997), pp. 149-63. 
By inviting the reader to engage in such a process, Erasmus's colloquium urges us not to resign ourselves, whatever happened in the past, and even if our action seems limited to us. The four old men's stories of failure and success encourage us, in Marcus Aurelius's words, to "be happy if one little thing leads to progress, and reflect on the fact that what results from such a little thing is not, in fact, so very little." ${ }^{20}$

\section{A Way of Life and a Mode of Discourse: The Case of Montaigne}

Erasmus's colloquium urges its Christian readers to cultivate a hermeneutics of desire privileging dutiful conduct. Its focus on a moderate use of pleasure for the sake of personal virtue also builds on classical ideals that correspond to Foucault's description of the Greek and Roman ethos in The Use of Pleasure. ${ }^{21}$ The Horatian notion of aurea mediocritas is also part of Montaigne's ideal at the end of the Essais. In the final pages of the chapter "Of Experience," he observes:

Moy, qui ay tant adoré, et si universellement, cet ariston metron du temps passé et ay pris pour la plus parfaicte la moyenne mesure, pretendray-je une desmesurée et montrueuse vieillesse?... Les plus belles vies sont, à mon gré, celles qui se rangent au modelle commun et humain, avec ordre, mais sans miracle et sans extravagance. (Essais, III, 13, pp. 1102, 1116) $)^{22}$

Shall I, who in all matters have so worshiped that golden mean of the past, and have taken the moderate measure as the most perfect, aspire to an immoderate and prodigious old age?... The most beautiful lives, to my mind, are those that conform to the common human pattern, with order, but without miracle and without eccentricity. (pp. 1030, 1044)

The classical heritage of Erasmus, Montaigne, and their contemporaries is no longer part of our twenty-first-century culture, yet it has not lost

20 Marcus Aurelius, The Meditations of the Emperor Marcus Antoninus, ed. and trans. A. S. L. Farquharson (Oxford: Clarendon Press, 1944), IX, 29, 5. This work first appeared in print after Erasmus's death. Whether Erasmus read this text or not is a moot point; what matters is its Stoic overtone, which for a Christian reader also strikes a Christian note.

21 Foucault's emphasis on self-mastery in the use of pleasure for the sake of civic virtue in the Platonic dialogues is, however, not really part of Erasmus's discussion in The Old Men's Chat.

22 See also a similar comment in the same chapter: "Le peuple se trompe: on va bien plus facilement par les bouts, où l'extremité sert de borne d'arrest et de guide, que par la voye du millieu..." (III, 13, p. 1110/ "Popular opinion is wrong: it is much easier to go along the sides, where the outer edge serves as a limit and a guide, than by the middle way...", p. 1039). 
its relevance, especially when we think about aging in terms of attitudes toward time. Indeed, practices exhibit their own continuity through time, and focus our attention to the construction of different forms of subjectivity through different types of relationship with ourselves.

Beginning with Plato, ancient philosophy represented itself as a training for death, understood as the separation of the soul from the body. In Phaedo, Socrates speaks of freeing the soul from the passions linked to the senses, to attain to an autonomy of thought. Pierre Hadot observes that from Socrates onward, "Training for death is training to die to one's individuality and passions in order to look at things from the perspective of universality and objectivity." ${ }^{23}$ Following this classical tradition, Montaigne in the chapter "Que philosopher c'est apprendre à mourir" (Essais I, 20) recalls well-known arguments to maintain his peace of mind. This technique can easily be adapted to other signs of human finitude, including the decline of our physical and cognitive capacities over time. Moreover, if philosophy is learning to die, it is therefore learning to live, and to live means aging, as Montaigne observes in "Of Experience" (III, 13, p. 1089/p. 1017).

For the Stoics and the Epicureans in particular, the fear of death can be overcome by training one's body, reason, imagination, and sensitivity to the prospect of one's end. Hence one has to use all the tools-rhetorical, physical, intellectual, and so on-at one's disposal. Stoic exercises of meditation on future evils (in texts by Epictetus, Cicero, and Seneca, among others), and Plutarch's similar practices to correct some weaknesses (including curiosity or gluttony), nourished Petrarch's self-portraits in the Secretum, the Rerum Vulgarium Fragmenta, and his correspondence. His attempts to find peace of mind through recurrent exercises to discipline his desires, his will, and his inclinations point out the importance of attention to oneself and vigilance. The Christian tradition fully assimilated these notions: one observes oneself, frees oneself from personal attachment to futile objects, and seeks to find happiness and peace of mind in inner independence. Pierre Hadot notes that linked to the meditation upon death, the value of the present instant plays a fundamental role in every classical philosophical school. ${ }^{24}$ I would add that this role takes its full meaning by the end of the journey of life, when the imminence of death reinforces the feeling of the scarcity of one's allotted time. Old age,

23 Hadot, Philosophy as a Way of Life, p. 95.

24 Ibid., p. 69. 
far more than youth, is the time of carpe diem. Montaigne, Petrarch, and Erasmus learned from the Stoics (especially Cicero and Seneca) and the Epicureans (including Horace) to grasp the fullness of the present and not be affected by things that are beyond human control, such as old age's physical frailty. "Quand je dance, je dance; quand je dors, je dors," Montaigne claims (III, 13, p. 1107/ "When I dance, I dance; when I sleep, I sleep," p. 1036). In Horace's words, "Let the soul which is happy with the present learn to hate to worry about what lies ahead." "He will be master of himself and live joyfully who can say, every day: 'I have lived', "Horace proclaims in his odes $(2,16 ; 3,29)$. Seneca also comments on this Epicurean motif in his Letters to Lucilius:

If God should grant us tomorrow as well, let us accept it joyfully. That person is most happy and in tranquil possession of himself who awaits tomorrow without worries. Whoever says "I have lived," gets up every day to receive unexpected riches. $(12,9)$

Only the present depends on us, Seneca adds in another letter: "He has peace of mind who has lived his entire life everyday" $(101,10)$.

In our modern world that encourages the constant dispersion of our thoughts, both Petrarch's and Montaigne's attitudes toward time act as a healthy reminder not to forget the present moment. Petrarch conceives this ideal in terms of tension and duty; Montaigne, at the end of his Essais in the chapter "Of Experience," sees it as an invitation to relaxation. Striving to free his attention from the woes of old age, he observes that the majority of us are tormented by fears, and hollow, senseless desires related to power, glory, wealth, or unbridled passions. The common characteristic of all anxieties and expectations is that they project us forward into an unknowable future. Montaigne confirms the quintessential Epicurean pleasure: the pleasure of living, and being in good health, and thereby experiencing the enjoyment of the present moment: "Pour moy donc, j'ayme la vie et la cultive telle qu'il a pleu à Dieu nous l'octroier" (III, 13, p. 1113/ "As for me, then, I love life and cultivate it just as God has been pleased to grant it to us" p. 1041). Later he adds: "C'est une absolue perfection, et comme divine de scavoyr jouyr loiallement de son estre" (III, 13 , p. 1115 / "It is an absolute perfection and virtually divine to know how to enjoy our being rightfully" p. 1044). Petrarch's focus on vigilance, personal effort, and moral conscience bears the imprint of Stoic philosophers, including Cicero's De Senectute, and relies also on Christian sources; its appeal is quite different from the expression of Montaigne's joy of existence at the end of the Essais. 
Montaigne's and Petrarch's respective self-portraits confirm that if aging gracefully is a way of life, it is also a mode of discourse. For Petrarch, this discourse has religious and ethical overtones, even if death and the afterlife are not its exclusive concern. The formative purpose of the Rime Sparse and the Secretum goes along with a rhetoric of "spiritual exercises" training the poet's persona with a nagging persistence, and trying to set him "right," in Petrarch's words (Sen. XVIII, 1, p. 672). ${ }^{25}$ His self-portraits present the kind of relationship the reader ought to have with himself. This relationship, which combines Christian and pagan ethical rules of conduct, requires continual elaboration since it experiences temporal variations along the life course. In a seemingly more casual way, the Letters of Old Age also give the reader exemplary models of conduct in the public and private spheres. Montaigne's Essais, as we shall see shortly, opened up different perceptions of the self. But regardless of their respective orientations, both Montaigne and Petrarch (and other writers considered in the previous chapters) "used" old age as a pretext to distinguish themselves from others by speaking their minds, by eating, drinking, and sleeping, by attitudes toward social and moral values as well as toward love.

Foucault's perspective on the care of the self provides a framework for seeing the discourse on aging gracefully as a way to constitute oneself through a set of practices (The Use of Pleasure, pp. 5-6). In Petrarch's and Montaigne's texts, aging is not presented as a homogeneous process that reduces each individual to the same characteristics, but as a discriminatory process, during the course of which essential personal features are revealed. ${ }^{26}$ Whereas Renaissance culture scripted old age into a small number of rigid categories, and offered simplistic, restrictive identities overly determined by the body, Petrarch's and Montaigne's self-portraits in later life point out the contradictions that constitute selfhood. Aging, understood as the human experience of time, allows them to recognize self as other, testifying to the dynamism of identity. In Petrarch's Secretum, Rime Sparse, and the Letters of Old Age, the aging self is "less an entity and more a kind of awareness in process." ${ }^{27}$ As an older subject, Montaigne is even more susceptible to narrative instability than Petrarch, and his

25 See chapter 2, the section on Petrarch. See also Zak, Petrarch's Humanism and the Care of the Self, especially the introduction.

26 This process is not simply a matter of free constitution of the self by the self but also points out that social practices "give birth" to new forms of subjects. See Foucault, Dits et écrits: 1954-1988, vol. 2, p. 539.

27 Eakin, Our Lives Become Stories, p. x. 
portraits are a site of conflicting versions of the self. His comments show his growing capacity to appreciate the multiple levels of his stories, and the multiple selves that tell them, as well as to revel in the play made possible by his detached view of himself. "On devient multitude," the nineteenth-century writer Amiel wrote in his later years. An avid reader of the Essais, he added a question that already obsessed Montaigne: "où réside en définitive notre Moi?"28 In the Essais, this multiplying effect epitomizes Montaigne's fascination with the mutability of existence, and his continuous investigation of the self. ${ }^{29}$

Petrarch's self-portraits strike a note of continuity, coherence, and integration. Montaigne, for his part, represents himself from various perspectives; this polymorphous representation is reinforced by his eclectic use of a vast repertoire of sources. Throughout his work, he combines, reworks, distorts, and questions different views on aging, and appropriates various classical practices of the self (the Stoic exercise of vigilance, the Epicurean focus on natural pleasures) to adapt them to his own purposes. His habit of juxtaposing contradictory quotations and combining different sources (Plutarch's moral comments, cynic criticism of the conventional wisdom on old age, Pyrrhonic suspension of judgment, etc.) conveys his skeptical view of bookish knowledge. The multiplication of this citational and referential device is a way to reposition himself in others' eyes; moreover, as Jean-Yves Pouilloux has shown, his Essais are a vast orchestration of different voices that are part of the creation of a plural yet cohesive identity. ${ }^{30}$

Elaborating on Foucault's views of the self, one might describe Montaigne's self-representations as fictions that are neither fixed nor stable. Montaigne's self is "not a thing" (an essence or a substantive entity), but rather a process of signification within an open system of discursive possibilities. ${ }^{31}$ The essayist recognizes himself in different types of relations with himself: politics (relations of power), erotics (relations of pleasure), and health care (relation of oneself to one's body) are all practical fields within which his aging self appears and which all have their possibilities of dangers and errors, their techniques and tactics for success,

28 Henri-Frédéric Amiel, Fragments d'un journal intime (Paris: Stock, 1931), vol. 2, p. 296. "One becomes a multitude... Where, ultimately, does our self dwell?"

29 See Jean-Yves Pouilloux's insightful study, Montaigne, une vérité singulière (Paris: Gallimard, 2012), and André Tournon, Routes par ailleurs. Le nouveau langage des "Essais" (Paris: Champion, 2006).

30 Pouilloux, Montaigne, une vérité singulière, pp. 12-55.

31 Pouilloux, Montaigne, une vérité singulière, provides similar comments, but from a different theoretical perspective. 
and their rewards. His knowledge of himself is worked out as a pragmatic matter, in terms of forms of attention to oneself and techniques of care of the self. Self-knowledge, and the self as an object of knowledge, therefore vary according to the essayist's perspective. However, this dynamic process of self-constitution also depends on historical conditions of possibility for such experience of the self. As Foucault notes:

Within the very history of care of the self, gnothi seauton does not have the same form and it does not have the same function. Consequently, the knowledge opened up and delivered by gnothi seauton is not going to be the same in each case. This means that the forms themselves of the knowledge which are put to work are not the same. This also means that the subject itself, such as it is constituted by the form of reflexivity proper to such and such a type of care, is going to change. ${ }^{32}$

It is this representation of a wide range of experiences (in the Latin sense of experimentation and observation) ${ }^{33}$ that is Montaigne's enduring legacy to the Western "culture" of graceful aging. "Vires acquirit eundo": like his book, Montaigne "gathered strength as he went." Experience taught him that growing old in a graceful way is a matter of using simultaneously or successively different "methods" - tension and relaxation, humor and detachment, play, indifference, and so on. As far as practice was concerned, he viewed the various arts of living from the Greco-Roman philosophical tradition as experimental laboratories, and did not hesitate to adopt a Stoic perspective just because he also benefited from an Epicurean point of view. He compared the consequences of various experiences which illuminate one another, and appropriated the parts that suited him best. Using a Stoic model when needed, adapting an Epicurean one according to the specific circumstances of the moment, appropriating yet another ancient model (successively or simultaneously), and more importantly, reactualizing all of them following his own views, was Montaigne's way of achieving a certain balance in later life.

By generating a plurality of observations on himself, Montaigne stressed the value of resilience in surviving the physical, psychological, and social challenges of old age. Today's social gerontologists note that rigid thinkers tend to become overwhelmed by their experience of old age; they cannot manage the medical and social challenges, and become depressed.

32 Foucault, L'Herméneutique du sujet, pp. 442-43. My translation.

33 On Foucault's definition of "experience," see Béatrice Han, Foucault's Critical Project: Between the Transcendental and the Historical, transl. E. Pile (Stanford: Stanford University Press, 2007), p. 156. 
In contrast, in Montaigne's Essais, growing old is an "art" - in the Greek sense of technè-perpetually in the making, and determined by the particularity of the circumstance and the moment since we are changing from one instant to another. The continuous distance of oneself from oneself is what becomes evident through this way of looking.

Montaigne's self-portraits in later life offer the reader a particularly astute and fruitful "mode d'emploi" — a user's guide — for old age: a narrative approach to the effects of time on the essayist's physical and cognitive capacities (whether these effects are real or not is another matter). His ways of coping with the woes of age in the chapter "On some verses of Virgil" and the prosopopoeia in "Of Experience" have striking similarities with the mètis, a "skill" that Jean-Pierre Vernant and Marcel Détienne see as a fundamental aspect of Greek thought. ${ }^{34}$ The mètis is a cunning form of intelligence, especially helpful when it comes to facing an overwhelming situation. Faced with a more powerful enemy or an obstacle impossible to overcome, it is useless to attempt a direct attack, or a face-to-face confrontation. The mètis operates indirectly, by seizing the right opportunity at the right moment. Since it reaches its goal by adjusting to specific circumstances, it requires a perceptive, flexible, and imaginative mind. Here experience, adaptation, and savoir-faire are more useful than reason and logic. Not surprisingly, there is no treatise on mètis because it is a "science of the singular": each case represents a unique set of constraints and opportunities. Obviously, the mètis is far from being a passive reaction to a difficult situation; it is a mode of production and invention.

Montaigne never mentions the mètis, but describes a similar practice in the brief chapter entitled "Of Diversion" ("De la diversion," III, 4). At the opening of this chapter, he explains how he capitalized on diversion's dual meaning — "divertir" and "détourner" (to distract, and to divert) — and on human inconstancy to help a lady to overcome her grief at her son's death. The theme of diversion is carried over into the following chapter, "On some verses of Virgil" (III, 5), where Montaigne experiments with the effects of diversion to chase away the gloom of old age. ${ }^{35}$ As he notes in "Of Diversion," this practice has a therapeutic goal:

34 Jean-Pierre Vernant and Marcel Détienne, Les ruses de l'intelligence. La mètis des Grecs (Paris: Flammarion, 1974).

35 On the connections between the two chapters, and on the use of diversion in "In some verses of Virgil"; see Cynthia Skenazi, "La diversion de la vieillesse. Les ruses de Montaigne”, in Vieillir à la Renaissance, ed. C. Winn and C. Yandell (Paris: Champion, 2009), pp. 339-57. 
Quand les medecins ne peuvent purger le catarre, ils le divertissent et le desvoyent à une autre partie moins dangereuse. Je m'apperçoy que c'est aussi la plus ordinaire recepte aux maladies de l'ame. (III, 4, p. 832)

When the doctors cannot purge a catarrh, they divert it and lead it off into some other less dangerous part. I observe that this is also the most ordinary remedy for ailments of the soul. (p. 766)

Whether in medicine or in daily life, diversion is the product of an active imagination that strives to adjust to the inevitable changes of aging rather than to endure them with passive resignation. The aging essayist's meditations on erotic Latin poetry in the chapter "On some verses of Virgil" (III, 5), and the prosopopoeia of the "mind" in "Of Experience" (III, 13) are examples of the mind's inventions to chase away the clouds of old age. ${ }^{36}$ The relief from such playful devices does not last; there will always be a need for renewed efforts. But it is in this space of play that resistance to the negative effects of time can "occur": there is always a way to effect a change within the age-related constraints imposed upon the essayist. In this perspective, old age is not simply repressive and limiting - it is also enabling. To continue to activate this experience, Montaigne keeps searching for techniques that respond to the difficulties of his present situation; he maintains an experimental attitude, a willingness to test new practices, and to reimagine the meaning and forms of his relation to himself and to others.

In Surveiller et punir: Naissance de la prison, and even more in La Volonté de savoir (the first volume of his Histoire de la Sexualité), Foucault suggests that in any relation of power, there is necessarily the possibility of diffuse and local resistances. ${ }^{37}$ Similarly, Montaigne's discourse on aging is a mediating and complicitous practice. It seeks to solve immediate problems - chasing away senile melancholy for a few hours, forgetting momentarily the woes of old age-through practices that belong to what Michel de Certeau calls the "invention of everyday life." ${ }^{38}$ These kinds of oppositional practices, de Certeau notes, are a matter of tactics, as opposed to strategies. Whereas strategy is the privilege of those who

36 See chapters 1 and 3 , the sections on Montaigne.

37 See especially pp. 126-27 of Histoire de la sexualité, vol. 1, La Volonté de savoir;

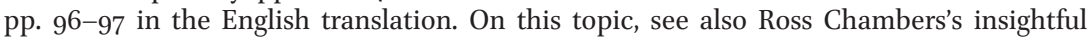
comments in Room for Maneuver. Reading (the) Oppositional (in) Narrative (Chicago: University of Chicago Press, 1991), pp. xi-xx.

38 Michel de Certeau, L'Invention du quotidien, vol. 1, Arts de faire (Paris: Gallimard, 1990). 
are masters of the terrain, tactics are the resource of those who must take advantage of momentary circumstances and chance opportunities to meet their goals. What all these oppositional behaviors have in common is using old age's stereotyped shortcomings (loquacity, lack of focus, idleness, etc.) for one's own purpose; they put old age's weaknesses in the service of the narrator's interest. Montaigne cannot change the effects of time on his body and mind; he can, in contrast, exploit their narrative potential, making losses at one level into gains at another. This move attests to the centrality of rhetorical training in Renaissance authors, but the effects go beyond technical mastery. In fact, authors and readers can be changed by stories of graceful aging.

The chapter "Of Vanity" (III, 9) reflects Montaigne's experimentation with an "old age style." Critics have noted the disorganization of this chapter, which places everything-even itself - under the sign of vanity. Referring to the common metaphor of writing as a journey, Montaigne defines himself as a loiterer, pointing out the chapter's random progression "by leaps and gambols" ("à sauts et à gambades" III, 9, p. 994/p. 925). ${ }^{39}$ Yet scholars have neglected another analogy that also describes this chapter's (real or apparent) lack of direction: "Here you have... some excrements of an aged mind, now hard, now loose, and always undigested," the essayist notes at the beginning of "Of Vanity" ("Ce sont icy... des excremens d'un vieil esprit, dur tantost, tantost lache et tousjours indigeste," p. 946/p. 876). He had a tendency to deprecate his literary production, yet as we shall see, he literally conceived this chapter as the production of an old mind. "Of Vanity" capitalizes on stereotyped, negative symptoms of aging that are beyond human control. This is, of course, a rhetorical tour de force, and a demonstration of Montaigne's intellectual alertness and vitality in his later years.

First, the length of the chapter bears out the stereotype of old age's loquacity. Old men are naturally talkative, Cato the Elder noted in De Senectute ("senectus est natura loquacior," 16, 55). His remark was already a commonplace in Cicero's time. Old Cephalus in Plato's Republic, for instance, recorded his increasing pleasure in conversing (I, 1328a), and Aristotle gave this observation a different twist by pointing out the selfishness of old people who speak solely of themselves (Rhetoric II, 13, 1390a). Erasmus's Praise of Folly also nourished Montaigne's thoughts on vanity

39 On travel as a metaphor for writing in the chapter "Of Vanity", see Mary McKinley, Les Terrains vagues des 'Essais' (Paris: Champion, 1996), pp. 145-6o; Terence Cave, Préhistoires, vol. 1 (Geneva: Droz, 1999), pp. 164-76; Paul J. Smith, “Montaigne, Juste Lipse et l'art du voyage," Romanic Review 94, 1-2 (2003), pp. 73-92. 
and garrulousness. ${ }^{40}$ Folly ironically claimed that the elder delights in life's ultimate pleasure: he talks too much, ${ }^{41}$ and loquacity is the best way to cope with the woes of the winter of life. Likewise, the essayist claims to write down every thought that comes to his mind without making any effort to build a coherent argument. The chapter "Of Vanity" progresses by way of loose connections rather than logical relations between causes and effects: one thing leads to another that in turn opens itself up to another remark, and so on-from approximate analogies to transformations, from vague continuities to ruptures.

Second, the chapter's disorganization is the alleged consequence of another stereotype of age: bad memory. Eramus's Folly saw this weakness as a blessing since forgetfulness prevents the elder from worrying about the past, the present, or the future. Building on this, "Of Vanity" claims to be the product of an aged mind failing to remember what it is speaking about, finding its arguments by coincidence, and unable to elaborate on them. ${ }^{42}$ In De Senectute, Cato the Ancient regularly exercised his memory (VII, 21); Montaigne on the other hand, rejects the social values underlying the art of memory, valuing instead disorder, lack of rigor, and absence of focus. ${ }^{43}$ The chapter capitalizes on these shortcomings of old age and progresses because of the weakening of Montaigne's intellectual capacities rather than in spite of such decline. Montaigne closely monitored the effects of this "old age style"; his alleged fear of boring the reader by repeating himself is futile. Moreover, he ironically observes that the chapter's length and detours are a way of keeping the reader's attention (III, 9, p. 995/p. 925), thereby confirming yet another stereotype of age: the elder's freedom of expression, and lack of concern for public opinion. In fact, the essayist's emphasis on his bad memory has a positive value in this respect: because Montaigne allegedly keeps forgetting other people's arguments, he cannot refer to them; therefore, he has to rely on his own judgment and observations.

Montaigne's reflections on the Roman ruins offer further insight on the creation of an "old age style" in "Of Vanity." The essayist had discovered

40 On Montaigne reader of Erasmus in "Of Vanity," see McKinley, Les Terrains vagues des 'Essais', pp. 105-26.

41 See chapter 1, the section on Erasmus's Praise of Folly.

42 On this aspect, see Montaigne's remark in III, 9, p. 994/p. 925.

43 See the following remark: "Quand je me suis commis et assigné entierement à ma memoire, je pends si fort sur elle que je l'accable: elle s'effraye de sa charge. Autant que je m'en rapporte à elle, je me mets hors de moy jusques à essaier ma contenance..." (III, 9, p. $963 /$ p. 893 ). 
the ruins of Rome at age forty-seven; his Journal de voyage en Italie gives a full account of this encounter, and is the basis of his observations in the Essais. ${ }^{44}$ In "Of Vanity" the ruins of Rome give the essayist a visual and spatial representation of the effects of aging, while offering an opportunity for personal comments. The ruins reminded Montaigne of his childhood (he knew Latin before French, and Ancient Rome before sixteenth-century Paris, he said), of his approaching death, of his vain lust for immortality epitomized by the much coveted title "Citizen of Ancient Rome" bestowed upon him. The ruins also made him aware of the instability of the self, lending themselves to a meditation on the survival of the past. For Montaigne, Imperial Rome's sites of memory embodied an image of history in its "excrements," to borrow his term for describing his own chapter (III, 9 p. $946 /$ p. 876 ).

Many contemporary writers had made similar observations, including Joachim Du Bellay in his Antiquitez de Rome. ${ }^{45}$ Moreover, in Montaigne's time, ruins and old age had become part of moral meditations on vanity in painting. Martin Van Heemskerck painted his self-portrait in front of the Coliseum (1553); twenty years later, he chose the same setting for another self-portrait. Echoing the crumbling monument, his aging face reminded the beholder of time's flight. More strikingly, a landscape (dated 1536) by Herman Posthumus showed an old man in the middle of ruins; a line by Ovid offered the following comment: "O tempus edax et vetustas omnia destruitis." Likewise, Michel Coxcie painted the old god Time among Ancient Rome's broken columns, with an hour-glass and a crutch. ${ }^{46}$

Montaigne had probably not seen these paintings, but he knew Du Bellay's Antiquitez de Rome. The presence of these paintings and of works such as Du Bellay's collection of sonnets confirmed the relationship between ruins, old age, and vanity in sixteenth-century arts and letters. Montaigne's originality is in the elaboration of this triple motif in the chapter "Of Vanity." The Roman ruins gave him a spatial image of time, an image made of juxtapositions and superimpositions. As noted in the Journal de voyage, the ruins gave a partial and anachronistic view of Rome's history since ancient fragments could be found on top of more

44 On Montaigne and the Roman ruins, see M. McGowan, The Vision of Rome in Late Renaissance France (New Haven: Yale University Press, 2000), pp. 228-50.

45 On the topic of the ruins of Rome, see Cynthia Skenazi, Le Poète architecte en France. Constructions d'un imaginaire monarchique (Paris: Champion, 2003).

46 See Sabine Foreo-Mendoza, Le Temps des ruines. L'éveil de la conscience historique à la Renaissance (Paris: Champvallon, 2002), chapter 4. 
recent ones, and grafted onto them. "Of Vanity" capitalized on similar effects of montage and discontinuity. The chapter is an "ill-fitted patchwork," Montaigne noted ("une marqueterie mal jointe" p. 964/p. 894). "My ideas follow one another, but sometimes it is from a distance, and look at each other, but with a sidelong glance ("mes fantasies se suyvent, mais par fois, c'est de loing, et se regardent, mais d'une veuë oblique" p. 994/p. 925), he observed later. He then added yet another remark on his tendency to omit the transition between different ideas: "I want the matter to make its own divisions. It shows well enough where it changes, where it concludes, where it begins, where it resumes, without my interlacing it with words, with links and seams..." ("J'entends que la matiere se distingue soy-mesmes. Elle montre assez où elle se change, où elle conclud, où elle commence, où elle se reprend, sans l'entrelasser de paroles, de liaison et de cousture..." p. 995/p. 926). Interestingly, this last remark precedes the description of the ruins of Rome.

Like the ruins of Rome, the successive editions of his Essais contain layers of texts from different periods (modern editors identify them with the letters A, B, and C); the text "grows old" in some parts, and not in others, unevenly. The paradox of his self-portraits as a writer growing old is that these representations stem as much from his alleged weakness as from the wisdom he acquired over time.

As Montaigne observes in the chapter "Du Repentir," over the years, "L'homme marche entier vers son croist et vers son decroist" (III, 2, p. 817/ "Man grows and dwindles in his entirety," "Of Repentance," p. 752). His remark stresses the human limits of self-control. Subjective experiences have their own historicity, and depend to a large degree on elements in the surrounding culture and society; yet some recent self-help books seem to ignore these limits, or even to deny them. Detailed lists of healthy menus and daily activities promise the elder a safe and easy way to Look Younger, Feel Younger, Be Younger, as a 2011 title puts it. ${ }^{47}$ By transforming health from a means of living well into an end in itself, these extreme views reveal the bankruptcy of an ideal unable to accommodate the realities of decline, and highlight our twenty-first century obsession with youth. ${ }^{48}$ The "feel younger" attitude counters the claim that aging is all about loss;

\footnotetext{
47 Bob Greene, Look Younger, Feel Younger, Be Younger (New York: Little Brown and Company, 2011).

48 There is a wide range of comments on this issue. See especially Margaret Morgenroth Gullette, Declining to Decline. Cultural Combat and the Politics of the Middle (Charlottesville: University Press of Virginia, 1997).
} 
yet by rejecting this view, it assumes that age has no meaning: people are supposed to live the same way, at the same pace, until death. This attitude has become more pervasive since the baby boomer generation began to hit its fifth decade. This is understandable - the natural impulse is to pretend to ignore the passage of time and to cling to the selves we have been for as long as possible. Despite good intentions, such extreme views may reinforce age discrimination, since they focus on the body, whose decline is at the heart of the negative perspective of old age. The unrealistic optimism of the "forever young" attitude and the exaggerated pessimism of the view of aging as decay are opposite reactions to the same anxiety, generated by our inability to master the process of aging. Both assumptions remind us that notions of old age are imposed by culture upon the elderly, giving them a role that they must accept more or less passively, which influences their personal experience of the passing of time.

Montaigne's self-portraits in later life in chapters such as "Of Vanity," "Of Experience," and "On some verses of Virgil" show us that freedom and vitality lie in choosing to live within our limits, even as we struggle against them. Acceptance involves a giving in, but not a giving up; it means going around obstacles, yielding, and adapting. As these texts show us, new forms of discourse and of life constantly arise as concrete responses to aging's frailty and shortcomings. Aging gracefully is an ongoing and experimental art focusing on the transformative effects of time and capitalizing on new possibilities.

In his dedication "To the Reader" ("Au Lecteur"), Montaigne announces that he has written the Essais in order to know himself. This introspective goal deserves closer scrutiny. Before Socrates, the notion of self-knowledge was a matter of practical advice in a specific setting. The Delphic oracle reminded the Greeks of the danger of hybris - pride. Before entering Apollo's sanctuary, the passer-by had to think about himself as humanmortal-and contemplate the distance separating man from the gods: "do not suppose yourself to be a god"; and "be aware of what you really ask when you come to consult the oracle." ${ }^{\prime 9}$ Likewise, by the end of the Essais, and of the chapter "Of Experience," the aging Montaigne refers to the temporal nature of human existence by quoting Plutarch in Amyot's recent translation:

D'autant es tu Dieu comme

Tu te recognois homme. (III, 13, p. 1115)

49 See Jean-Pierre Vernant, Entre mythe et politique (Paris: Seuil, 1996), p. 219. 
You are as much a god as you will own

That you are nothing but a man alone. (p. 1044)

Accepting the very signs of one's finitude is a fundamental rule of the art of aging gracefully. Yet it is impossible not to notice how different Montaigne's views on growing old are from the prevailing perspectives of his time. In his Epithetes (first published in 1571, seventeen years before Montaigne's 1588 edition of the Essais), Maurice de La Porte gathered the adjectives that contemporary poets used in conjunction with the term "vieillesse." Except for a few terms ("honoree, paisible, saincte"; "honored, peaceful, sainted"), the list refers exclusively to old age's stereotyped shortcomings. ${ }^{50}$ About a hundred years later, Pierre Richelet's Dictionnaire françois (1679) strikes the same note, stressing old age's decrepitude, and melancholy. ${ }^{51}$ At the same time, Antoine Furetière's Dictionnaire universel (169o) presents a slightly more positive image by stressing the stereotypes of old age's experience and the respect due to the elder:

Vieillesse. Le dernier âge de la vie. Les Sibylles ont vescu jusqu'à une vieillesse decrepite. Il faut que chacun fasse honneur à la vieillesse. La jeunesse est folle, et parfois la vieillesse, dit Moliere. On dit proverbialement, Si jeunesse sçavoit, et vieillesse pouvoit, pour dire, Si on pouvoit joindre la force et l'experience. ${ }^{52}$

Old Age. The last age of life. The Sibyls lived up to decrepitude. Everyone must honor old age. Youth is foolish, and so is old age sometimes, Molière says. One says proverbially, If youth knew, and if old age could, so as to say, If one could join strength and experience.

If the dictionaries kept repeating the traditional clichés about old age, the Essais, however, influenced the reading of De Senectute in the seventeenth century, and put Cicero's unconditional apology of old age in a more

50 Maurice de La Porte, Les Epithetes (Paris: Gabriel Buon, 1571; Geneva, Slatkine Reprints, 1973), ff $277 \mathrm{~V}^{\circ}-278 \mathrm{r}^{\circ}$. "Vieillesse. Fleurie. I[d est] blanche, inutile, chancelante, laide, chetive, rechignarde, triste, morne, courbe ou courbee, infirme, pauvre, antique, otieuse, paisible, inopinee, sobre, fragile, plaintive, importune, sommeilleuse, moleste, honoree, precipitieuse."

51 “Vieillesse. C'est le tems de la vie de l'homme, qui est entre l'âge viril, et l'âge décrépite [sic]. C'est un temperament du corps, sec et froid, produit par une longue suite d'années. [Arriver à une vieillesse honorable]. L'inutile vieillesse au tombeau nous apelle. La vieillesse est ordinairement chagrine, et surtout la dernière vieillesse qui commence à soixante et dix ans, et va jusques à la fin de la vie". Pierre Richelet, Dictionnaire françois, vol. 2 (Geneva: Slatkine, 1970), p. $5^{28}$.

52 Antoine Furetière, Dictionnaire universel, vol. 3 (Rotterdam: Arnout and Reinier Leers), 169o, no page number. 
skeptical perspective. ${ }^{53}$ Morever, Montaigne's vast erudition was not lost to seventeenth-century writers, and provided them with an anthology of classical comments on old age. In the same spirit, the 1602 edition of the Essais, published by the Parisian librarian Abel L'Angelier, appended to Montaigne's work a selection of the author's "rarest remarks" ("les plus rares remarques") organized in alphabetic order, like a dictionary. Interestingly, when it came to Montaigne's comments on "vieillesse" and "vieillard" (old age, old man), the compiler chose a dozen of sentences that all strike a negative note, since they are out of context. ${ }^{54}$ Gone were Montaigne' s refusal of dogmatism, his complex variations of mood between the "jovial and the melancholy," as a 1588 addition to the chapter "Of Presumption" puts it (II, 17, p. 641/p. 591), and his superimposition of both states of mind.

At about the same time, a similar effort to streamline the Essais's nuanced observations on the effects of time on the human body and mind appears in the treatise of one of Montaigne's "disciples," Pierre Charron. In De la Sagesse (1601), Charron puts together comments on old age taken from different chapters of the Essais, without paying attention to the context of their occurrence, or their ironic tone. ${ }^{55}$ Once again, Charron did not take into account the fact that play offered Montaigne a setting in which to control external forces such as the process of aging. Moreover, play produces joy, which adds life to years.

Montaigne's stories of later life in the Essais not only set him apart from his contemporaries, and attest to the "singularity" of his self; they also transcend the particularities of Montaigne's personality and time. In fact, they have not ceased to speak to their readers over the centuries; André Gide's and Amiel's self-portraits in later years, for instance, remain indebted to Montaigne's, and they are not the only ones. As Simone de Beauvoir, a pioneer of aging studies perceptively noted, Montaigne's most negative comments on the process of growing old need a closer look:

there is a curious paradox that may have escaped him [Montaigne] but that is strikingly obvious to the reader: the Essais become richer and richer, more and more intimate, original and profound as the author of the book

53 Emmanuel Bury, "Fortunes du De Senectute de Cicéron au XVII ${ }^{\mathrm{e}}$ siècle," in Ecrire le vieillir, ed. Alain Montandon (Clermont-Ferrand: Presses Universitaires Blaise Pascal, 2005), pp. 33-57.

54 Les Pages du Sieur de Montaigne in Essais (Paris: L'Angelier, 1602), repr. in the Essais, J. Céard et al. eds. (Paris: Livre de Poche, 2001), p. 1805.

55 Pierre Charron, De la Sagesse (Paris: Fayard, 1986), I, 35, pp. 225-26. 
advances in age.... It was when he felt that his powers had declined that he was at his greatest. But no doubt he would never have attained this greatness but for the severity with which he treated himself. ${ }^{56}$

\section{In Vino Veritas}

"One man in his time plays many parts," Jaques says in Shakespeare's As You Like It. He then describes seven stages of life on the world's stage, from the mewling and puking infant to the decrepit old man. Jaques is prompted to this reflection by spectacles of suffering and injustice:

And so from hour to hour we ripe, and ripe,

And then from hour to hour we rot, and rot;

And thereby hangs a tale. (II, 7 , ll. 26-28) ${ }^{57}$

Despite countless scientific and technological improvements over the centuries, life has always been-and will always be-a story of eventual "rotting," in Shakespeare's words. One may be tempted to stop here and conclude that the care of the self has a limited and rather modest effect, since it can only delay the universal law of biological decline. Yet Montaigne's self-portraits in later years allow us to consider Jaques's last line more carefully, because telling this "tale" can become a way to compensate for losses and even to turn them into narrative opportunities. What matters is not what growing old is - a process of "rotting" - but what this process can do at the discursive level. Montaigne's self-portraits capitalize on the seductive power of fables to divert the negative aspects of the effects of time on human beings. His stories of later life do not challenge human finitude but work with and within the process of "rotting." And the pleasure the narrative delivers is still available at a later date and in changed historical circumstances.

Let's therefore imagine Jaques's melancholic meditation on the stages of life from the perspective of a bottle of wine. After all, Galen recommends wine that warms and hydrates the elder, and Renaissance health regimens for the elderly follow his advice. Likewise, at the end of his book On Longevity (De Vita longa), Ficino praises Bacchus who preserves youth by offering humankind "the sweetest wine"; and in wine "perpetual

56 Simone de Beauvoir, The Coming of Age, pp. 159-6o.

57 William Shakespeare. As You Like It, ed. J. H. Walter (London: Heinemann Educational Books, 1965). 
freedom from care" (De Vita libri tres, II, 20, p. 235). ${ }^{58}$ For his part, Laurent Joubert also values wine that cheers the elder up, ${ }^{59}$ and Erasmus collected proverbs on wine in his Adages. Wine is beneficial for the elder's cold and dry body; moreover, it sparkles the convivial exchanges that enhance the social quality of later life. Even Petrarch, who claimed to be addicted to water, did not despise wine when taken in moderation.

Since Montaigne had a vineyard, I will choose a wine produced in his region and whose name recalls Montaigne's given name, Michel Eyquem. The Château d'Yquem is a "premier cru classé supérieur" (the highest rating in the official French system of wine classification). Special wine growing practices already existed by 1593 when Jacques Sauvage, a descendent of a local noble family, was given tenure over Yquem. The Sauvage family gradually consolidated the vineyard as we know it today. The Château d'Yquem wine gains in stature as it ages - even up to a century, if the bottles have been cared for. ${ }^{60}$ The Sauternes grapes are susceptible to attack by a mold, Botrytis cinerea. Botrytis grows on many fruits and vegetables, usually producing an unappetizing gray rot, but in the environment of Sauternes, it can do something quite magical to grapes. Called pourriture noble, or noble rot, it causes them to darken and shrivel and lose water, greatly concentrating sugar within. Only fully botrytized grapes are harvested to make the wine of d'Yquem. They have to be handled carefully because the mold has weakened their skins. The wine undergoes a threeyear period of barrel aging, during which slow oxidation occurs, as well as secondary fermentation by yeasts and bacteria and an exchange of chemical compounds with the wood. During the fourth spring after vintage, the wine is bottled, but the process of aging continues.

By different means, the Château d'Yquem wine and Montaigne's selfportraits in later life in the Essais found ways to transcend the stereotyped young-versus-old oppositions. Aging made them more valuable, thereby demonstrating the positive potential of decay, since the "mold" is part of the process. As a sixteenth-century French proverb put it: "Vin vieil chanson nouvelle donne." 61

58 See chapter 1, the section on Ficino.

59 Laurent Joubert's Second Part of the Popular Errors, p. 29.

60 See the Château d'Eyquem's website www.yquem.fr and A. Weil, Health by Aging. A Lifelong Guide to your Physical and Spiritual Well-Being (New York: Knopf, 2005), pp. 104-6.

61 "An old wine gives a new song." Jean-Antoine de Baïf, Mimes, enseignemens et proverbes, ed. J. Vignes (Geneva: Droz, 1992), II, p. 805. 


\title{
BIBLIOGRAPHY
}

\author{
Primary Sources
}

Aristotle. The Complete Works of Aristotle. Edited by J. Barnes. Princeton: Princeton University Press, 1984.

—. Generation of Animals. Edited and translated by G. P. Goold. The Loeb Classical Library, Cambridge, Mass.: Harvard University Press, 1979.

- Nicomachean Ethics. Edited and translated by E. D. Ross. Oxford: Oxford University Press, 1980.

- On Rhetoric: A Theory of Civic Discourse. Edited and translated by G. Kennedy. Oxford: Oxford University Press, 2007.

Augustine, Saint. Retractationum libri II. Edited by A. Mutzenbecher. Turnhout: Brepols, 1984 .

- Sermo 216 Ad Competentes, in Patrologia Latina, vol. 178. Edited by J. P. Migne Turnhout: Brepols, 1975, pp. 127-47.

Bacon, Francis. The Instauratio magna. Vol. 3. Historia naturalis et experimentalis. Historia ventorum. Historia vitae et mortis. Edited by G. Rees. Oxford: Clarendon Press, 2007.

Baïf, Jean-Antoine de. Mimes, enseignemens et proverbes. Edited by J. Vignes. Geneva: Droz, 1992.

Binet, Claude. La Vie de Pierre de Ronsard. Edited by P. Laumonier. Geneva: Slatkine Reprints, 1969.

Bodin, Jean. La République. Edited by C. Frémont, M.-D. Couzinet, and H. Rochais. 6 vols, Paris: Fayard, 1986.

—. The Six Books of the Commonwealth. Facsimile of the 1606 English translation. Edited by K. D. McRae. Cambridge, Mass.: Harvard University Press, 1962.

Bracciolini, Gian Francesco. Un Vieillard doit-il se marier? Edited and translated by Alcide Bonneau. Paris: Liseux, 1877.

Cardano, Girolamo. The Book of My Life. Translated by J. Stoner. London: Dent, 1931.

Castiglione, Baldesar. The Book of the Courtier. Translated by C. Singleton. Edited by D. Javitch. New York and London: Norton and Company, 2002.

- Il Libro del Cortegiano, Edited by B. Maier. Turin: Unione Tipografico-Editrice Torinese, 1964.

Charron, Pierre. De la Sagesse. Paris: Fayard, 1986.

Cicero. De Senectute, De Amicitia, De Divinatione. Edited and translated by W. A. Falconer. London: Heinemann, 1923.

- Tusculan Disputations. Edited by A. E. Douglas. Warminster: Aris and Phillips, 1985 .

Clermont, Catherine de. Album de poésies (Manuscrit français 25455 de la BNF). Edited by Colette H. Winn and François Rouget. Paris: Champion, 2004.

Cornaro, Luigi. Discorsi della vita sobria. Venice: Brogiollo, 1620.

— - Discourses on the Sober Life (Discorsi Della Vita Sobria). Being the Personal Narrative of Luigi Cornaro (1467-1566, A.D.). No translator's name. New York: Crowell, no date.

—. De la sobriété. Edited by G. Vigarello. Grenoble: Millon, 1991.

- Trattato della vita sobria. Venice: no editor's name, 1558.

Diogenes Laertius. Lives of Eminent Philosophers. Edited and translated by R. D. Hicks. Cambridge, Mass.: Harvard University Press, 1958-59.

Du Bellay, Joachim. Les Antiquitez de Rome. Edited by F. Joukovsky and D. Aris. Paris: Garnier, 1996.

—. La Deffence et Illustration de la langue françoyse. Edited by Jean-Charles Monferran. Geneva: Droz, 2001. 
Du Laurens, André. Discours de la conservation de la veue: des maladies melancholiques, des catarrhes et de la vieillesse. Paris: Mettayer, 1597.

Du Perron, Jacques Davy. Oraison funèbre sur la mort de Ronsard. Edited by M. Simonin. Geneva: Droz, 1985 .

- Perroniana. Cologne, 1694.

Erasmus. Collected Works of Erasmus. 82 vols. Toronto: University of Toronto Press, 1974-.

- Moriae Encomium. Basel: Froben, 1540. http://openlibrary.org/books/OL24970664M/ Moriae_encomium_id_est_Stulticiae_laudatio_ludicra_declamatione_tractata.

- The Praise of Folly. Edited and translated by C. H. Miller. New Haven: Yale University Press, 1979 .

—. Opus Epistolarum Desiderii Erasmi. Edited by P. S. Allen, Oxford: Clarendon Press, 1906-58.

Ficino, Marsilio. Three Books on Life. Edited and translated by C. Kaske, and J. Clark. Binghamton: Medieval and Renaissance Texts and Studies, 1989.

Furetière, Antoine. Dictionnaire universel. Rotterdam: Arnout and Reinier Leers, 1690.

Galen. On Hygiene. De Sanitate tuenda. Edited and translated by R. M. Green. Springfield, Il.: Thomas, 1951.

—. Opera omnia. Edited by C. G. Kühn. 6 vols. Leipzig: s.n. 1821-33. Reprint. Hildesheim: s.n., $1964-65$.

Goulart, Simon. Le Sage vieillard décrit de divers autheurs. Lyon: A. de Harsy, 1606.

- The Wise Old Man. No translator's name. London: N. Bourne, 1621.

Guicciardini, Niccolò. L'Ore di ricreazione. Edited by A.-M. Van Passen. Rome: Bulzoni, 1990.

Guido da Vigevano. Liber conservationis sanitatis senis. Paris: Bibliothèque Nationale, fonds latin 11015 .

Hippocrates. Aphorisms. Greek edition, E. Littré. Amsterdam: Hakkert, 1962.

Horace. Odes and Epodes. Edited and translated by N. Rudd. Cambridge, Mass.: Harvard University Press, 2004.

Isidore of Seville. The Etymologies of Isidore of Seville. Edited and translated by S. Barney. Cambridge: Cambridge University Press, 2006.

Joubert, Laurent. The First Part of the Popular Errors. Edited and translated by G. de Rocher. Tuscaloosa: University of Alabama Press, 1989.

- The Second Part of the Popular Errors. Edited and translated by G. de Rocher. Tuscaloosa: University of Alabama Press, 1995.

—. Treatise on Laughter. Edited and translated by G. de Rocher. Tuscaloosa: University of Alabama Press, 1980.

La Porte, Maurice de. Les Epithetes. Paris: Gabriel Buon, 1571; Geneva: Slatkine Reprints, 1973.

Liber de Pomo et Morte. Edited by D. S. Margoliouth in Journal of the Royal Asiatic Society, 1892, pp. $187^{-252}$.

Machiavelli, Niccolò The Art of War. Translated by C. Lynch. Chicago: Chicago University Press, 2003.

—. Discorsi sopra la prima Deca di Tito Livio. Dell'Arte della guerra. Dalle Legazioni. Edited by R. Rinaldi. Turin: UTET, 2006.

Marcus Aurelius. The Meditations. Edited and translated by A. Farqhuarson and R. Rutherford. Oxford: Oxford University Press, 1989.

- The Meditations of the Emperor Marcus Antoninus. Edited and translated by A. S. L. Farquharson. Oxford: Clarendon Press, 1944.

Monluc, Blaise de. Commentaires. Edited by P. Courteault. Paris: Gallimard, 1964.

Montaigne, Michel de. Les Essais. Edited by P. Villey and V.-L. Saulnier. Paris: PUF, 2004.

—. Les Essais. Edited by J. Céard, D. Bjaï, B. Boudou, and I. Pantin. Paris: Le Livre de Poche, 2001.

- Les Essais. Edited by J. Balsamo, M. Magnien, and C. Magnien-Simonin. Paris: Bibliothèque de la Pléiade, Gallimard, 2007. 
—. CEuvres complètes. Edited by A. Thibaudet and M. Rat. Paris: Gallimard, 1962.

. The Complete Works of Montaigne. Translated by Donald M. Frame. New York: Knopf, 2003 .

Nucerin, Jean. Proverbes communs et belles sentences pour familièrement parler françois à tout propos, tres utiles et necessaires à toutes gens composez par I. Nucerin. Paris: Picard, 1960.

Pasquier, Etienne. Les Jeus Poétiques. Edited by Jean-Pierre Dupouy. Paris: Champion, 2001.

- Oeuvres complètes. 2 vols. Geneva: Slatkine Reprints, 1971.

Petrarch, Francesco. De Remediis utriusque fortunae. 2 vols. Edited and translated by C. H. Rawski. Bloomington: Indiana University Press, 1991.

—. Le Familiari. Edited by V. Rossi. Florence: Sansoni, 1934.

- Letters on Familiar Matters (Rerum Familiarium Libri). 3 vols. Edited and translated by Aldo Bernardo. Albany, New York: State University of New York Press, 1975; Baltimore: Johns Hopkins University Press, 1985.

—. Les Lettres de la vieillesse. 4 vols. Edited by E. Nota, U. Dotti, Claude Laurens, and Frank La Brasca. Paris: Les Belles Lettres, 2002-6.

—. Le "Senili" secondo l'edizione Basilea 1581. Edited by M. Guglielminetti, M. Martelli, and P. Pellizzari. Turin: L'Artistica Editrice, 2004.

- Letters of Old Age (Rerum Senilium Libri). 2 vols. Edited and translated by A. S. Bernardo, S. Levin, and R. Bernardo. Baltimore: Johns Hopkins University Press, 1992.

—. Lyric Poems. The Rime Sparse and Other Lyrics. Edited and translated by Robert M. Durling. Cambridge, Mass.: Harvard University Press, 1976.

—. Opere latine di Francesco Petrarca. Edited by A. Bufano. Turin: Unione tipograficaeditrice Torinese, 1975 .

- Secretum. Edited by Enrico Carrara. In Petrarch, Prose, edited by Guido Martellotti and P. G. Ricci. Milan and Naples: Ricciardi, 1955.

—. Il mio Segreto. Edited by Ugo Dotti. Milan: Rizzoli, 2000.

—. My Secret Book. Translated by J. G. Nichols. London: Hesperus, 2002.

- The Secret. Translated by Carol E. Quillen. New York: St Martin's Press, 2003.

Plato. Laws. Edited and translated by T. Pangle. New York: Basic Books, 1980.

—. The Republic. Edited and translated by R. Allen. New Haven: Yale University Press, 2006.

—. Timaeus. Edited and translated by R. D. Archer-Hind. New York: Arno Press, 1973.

Plutarch. Moralia. Translated by H. N. Fowler. Loeb Classical Library: London, Harvard University Press, 1998.

_. Préceptes de santé. In Traités 10-14, edited by J. Defradas, J. Hani, and R. Klaert. Paris: Les Belles Lettres, 1985 .

Quintilian. Institutio oratoria. The Orator's Education. 5 vols. Edited and translated by D. A. Russell. Loeb Classical Library, Cambridge, Mass.: Harvard University Press, 2001.

Ronsard, Pierre de. Oeuvres. Edited by Jean Céard, Daniel Menager, and Michel Simonin. 2 vols. Paris: Gallimard, 1993 .

—. CEuvres complètes. 20 vols. Edited by P. Laumonier, R. Lebègue, and I. Silver. Paris: STFM, 1914-74.

—. Sonnets pour Hélène. Edited by Malcolm Smith. Geneva: Droz, 1998.

Sainte-Marthe, Scévole de. Opera, tum poetica, tum ea quae soluta oratione scripsit. Scaevolae Sammarthani Lucubrationum, pars altera, qua continentur Gallorum doctrinae illustrium, qui nostra patrumque memoria floruerunt, elogia. Paris: Durand, 1616.

Seneca. Ad Lucilium. Epitulae Morales. Edited and translated by R. Gunmere. Cambridge, Mass.: Harvard University Press, 1953.

Shakespeare, William. As You Like It. Edited by J. H. Walter. London: Heinemann Educational Books, 1965 .

Virgil. Eclogues. Edited and translated by R. Coleman. Cambridge: Cambridge University Press, 1977 . 
Zerbi, Gabriele. Gerontocomia. Rome: Eucharius Silber, 1489. http://gallica.bnf.fr/ark:/12148/ bpt6k584977.

- Gerontocomia: On the Care of the Aged. Edited and translated by R. Lind. Philadelphia: American Philosophical Society, 1988.

\section{Secondary Sources}

Albala, Ken. Eating Right in the Renaissance. Berkeley: University of California Press, 2002.

Allen, Michael J. B., Valerie Rees, and Martin Davies, eds. Marsilio Ficino: his Theology, his Philosophy, his Legacy. Leiden: Brill, 2002.

Amiel, Henri-Frédéric. Fragments d'un journal intime. 2 vols. Paris: Stock, 1931.

Ascoli, Albert. A Local Habitation and a Name: Imagining histories in the Italian Renaissance. New York: Fordham University Press, 2011.

Baars, Jan. "Philosophy of Aging, Time, and Finitude." In T. R. Cole, R. E. Ray, and R. Kastenbaum, A Guide to Humanistic Studies in Aging. What Does It Mean To Grow Old?, pp. $107-28$.

Barolini, Teodolinda and Wayne Storey, eds. Petrarch and the Textual Origins of Interpretation. Leiden: Brill, 2007.

Beauvoir, Simone de. The Coming of Age. Translated by P. O'Brian. New York: Putnam's Sons, 1972.

Bellenger, Yvonne. "Le Thème de la vieillesse dans le livre III des Essais." In Des Signes au sens: lectures du livre III des 'Essais.' Journées d'Etudes du Centre Montaigne de Bordeaux 14-15 novembre 2002, edited by Françoise Argod-Dutard, pp. 201-16. Paris: Champion, 2003.

Bergdolt, Klaus. Wellbeing. A Cultural History of Healthy Living. Translated by J. Dewhurst. London: Polity, 2008.

Bernauer, James, and David Rasmussen, eds. The Final Foucault. Cambridge, Mass.: MIT Press, 1988.

Bierlaire, Franz. Erasme et ses Colloques: le livre d'une vie. Geneva: Droz, 1977.

Biggs, Simon. "Choosing not to be Old. Masks, Bodies and Identity Management in Later Life." Ageing and Society 18 (2007), pp. 209-21.

Bois, Jean-Pierre. Les Vieux de Montaigne aux premières retraites. Paris: Fayard, 1989.

Boucher, Jacqueline. Société et Mentalités autour de Henri III. Paris: Champion, 2007.

Bourdelais, Patrice. Le Nouvel âge de la vieillesse. Histoire du vieillissement de la population. Paris: Odile Jacob, 1993.

Bouteiller, Paul. Recherches sur la vie et la carrière d'Etienne Pasquier, historien et humaniste du XVI ${ }^{e}$ siècle. Paris: Editions I.S.I., 1989.

Bowen, Barbara. "Montaigne's Anti-Phaedrus: 'Sur des vers de Virgile' (Essais III, 5)." Journal of Medieval and Renaissance Studies 5, 1(1975), pp. 107-22.

Brush, Craig B. "What Montaigne has to say about old age." In $O$ un amy! Essays on Montaigne in Honor of Donald M. Frame, edited by Raymond C. La Charité. Lexington, Ky: French Forum, 1977, pp. 89-118.

Burckhardt, Jacob. The Civilization of the Renaissance in Italy. Translated by S. C. C. Middlemore, with an introduction by B. Nelson and C. Trinkaus. New York: Harper, 1958.

Burke, Peter. The Fortunes of the Courtier. University Park: Pennsylvania State University, 1995 .

Bury, Emmanuel. "Fortunes du De Senectute de Cicéron au XVII ${ }^{e}$ siècle." In Ecrire le vieillir, edited by Alain Montandon, pp. 33-57. Clermont-Ferrand: Presses Universitaires Blaise Pascal, 2005.

Byl, Simon. "La Gérontologie de Galien." History and Philosophy of the Life Sciences, 10, 1 (1988), pp. 73-92.

Campbell, Erin. "The Art of Aging Gracefully: The Elderly Artist as Courtier in Early Modern Art Theory and Criticism." Sixteenth Century Journal 33, 2 (2002), pp. 321-31. 
-, ed. Growing Old in Early Modern Europe. Cultural Representations. Burlington, VT: Ashgate, 2006.

Campbell, Julie. Literary Circles and Gender in Early Modern Europe. A Cross-Cultural Approach. Burlington, VT: Ashgate, 2006.

Cave, Terence. Pré-histoires. Vol. 1. Geneva: Droz, 1999.

- - ed. Ronsard the Poet. London: Methuen, 1973.

Certeau, Michel de. L'Invention du quotidien. Vol. 1, Arts de faire. Paris: Gallimard, 1990.

—. The Practice of Everyday Life. Translated by S. Rendall. Berkeley: University of California Press, 1984.

Chambers, Ross. "Gossip and the Novel: Knowing Narrative and Narrative Knowing in La Fayette and Proust." Australian Journal of French Studies 23, 2 (1986), pp. 212-32.

—. Room for Maneuver. Reading (the) Oppositional (in) Narrative. Chicago: Chicago University Press, 1991.

Chew, Samuel. The Pilgrimage of Life. New Haven: Yale University Press, 1962.

Clark, Kenneth. "The Artist Grows Old." Daedalus 135, 1 (2006), pp. 77-90.

Classen, Albrecht, ed. Old Age in the Middle Ages and the Renaissance: Interdisciplinary Approaches to a Neglected Topic. New York: De Gruyter, 2007.

Cole, Thomas, R. The Journey of Life. A Cultural History of Aging in America. Cambridge: Cambridge University Press, 1991.

Cole, Thomas R., R. E. Ray, and R. Kastenbaum, eds. A Guide to Humanistic Studies in Aging. What Does It Mean To Grow Old? Baltimore: Johns Hopkins University Press, 2010.

Conche, Marcel. Montaigne ou la conscience heureuse. Paris: PUF, 2002.

Copenhaver, Brian. "Scholastic Philosophy and Renaissance Magic in the De Vita of Marsilio Ficino." Renaissance Quarterly 87, 4 (1984), pp. 523-54.

Creore, Alvin. A Word-Index to the Poetic Works of Ronsard. London: Laney and Son Ltd, 1972.

Debailly, Pascal, ed. Le Livre III des 'Essais' de Montaigne. Actes de la journée d'étude 'Montaigne.' Cahiers Textuel 26, Paris: Université Paris-7 Denis Diderot, 2003.

Demonet, Marie-Luce, and Alain Legros, eds. L'Ecriture du scepticisme chez Montaigne. Geneva: Droz, 2004.

Denizot, Véronique. Ronsard. "Les Amours.” Paris: Gallimard, 2002.

Desan, Philippe, ed. Dictionnaire de Montaigne. Paris: Champion, 2007.

Detel, Wolfgang. Foucault and Classical Antiquity. Power, Ethics and Knowledge. Translated by D. Wigg-Wolf. Cambridge: Cambridge University Press, 2005.

Dove, Margaret. The Perfect Age of Man's Life. Cambridge: Cambridge University Press, 1986.

Dreyfus, Hubert and Paul Rabinow, Michel Foucault, Beyond Structuralism and Hermeneutics. Chicago: University of Chicago Press, 1983.

Durling, Richard J. "A Chronological Census of Renaissance Editions and Translations of Galen." Journal of the Warburg and Courtauld Institutes 24, 3-4, (1961), pp. 239-305.

Eakin, John Paul. Our Lives Become Stories. Making Selves. Ithaca: Cornell University Press, 1999 .

Elias, Norbert. The History of Manners. The Civilizing Process. Translated by E. Jephcott. New York: Urizen, 1978.

Featherstone, Michael and A. Wernick. Images of Aging: Cultural Representations of Later Life. London: Routledge, 1995.

Finlay, Robert. "The Venetian Republic as a Gerontocracy: Age and Politics in the Renaissance." Journal of Medieval and Renaissance Studies 8, 2 (1978), pp. 157-78.

Folts, James D. "Senescence and Renascence: Petrarch's Thoughts on Growing Old." Journal of Medieval and Renaissance Studies 10, 2 (1980), pp. 207-37.

Ford, Philip. "Ronsard, amant vieillissant dans les Sonets pour Hélène." In C. Winn and C. Yandell, Vieillir à la Renaissance, pp. 107-17.

Foreo-Mendoza, Sabine. Le Temps des ruines. L'éveil de la conscience historique à la Renaissance. Paris: Champvallon, 2002. 
Foucault, Michel. L'Archéologie du savoir. Paris: Gallimard, 1969.

The Archeology of Knowledge. Translated by S. Smith. London: Tavistock, 1977.

—. Dits et écrits: 1954-1988. 4 vols. Paris: Gallimard, 1994.

_ . "The Ethic of Care for the Self as a Practice of Freedom. An interview." In The Final

Foucault, edited by James Bernauer and David Rasmussen, pp. 4-15.

—. Foucault Live: Collected Interviews 1961-1984. Edited by Sylvère Lotringer. New York: Semiotext(e), 1996.

—. The Foucault Reader. Edited by Paul Rabinow. New York: Pantheon, 1984.

—. L'Herméneutique du sujet. Cours au Collège de France 1981-1982. Edited by F. Ewald,

A. Fontana and F. Gros. Paris: Gallimard, 2001.

- The Hermeneutics of the Subject. Lectures at the Collège de France 1981-1982. Trans-

lated by G. Burdell. New York: Palgrave, 2005 .

- Histoire de la folie à l'âge classique. Paris: Gallimard, 1961.

—. Madness and Civilization. Translated by R. Howard. New York: Vintage Books, 1973.

—. Histoire de la sexualité. Vol. 1. La Volonté de savoir. Paris: Gallimard, 1976.

—. Histoire de la sexualité. Vol. 2. L'Usage des Plaisirs. Paris: Gallimard, 1984.

—. Histoire de la sexualité. Vol. 3. Le Souci de soi. Paris: Gallimard, 1976.

- The History of Sexuality. Vol. 1. An Introduction. Translated by R. Hurley. New York:

Vintage Books, 1980.

. The History of Sexuality. Vol. 2. The Use of Pleasure. Translated by R. Hurley. New York: Pantheon Books, 1986.

- The History of Sexuality. Vol. 3. The Care of the Self. Translated by R. Hurley. New York: Vintage Book, 1986.

—. Naissance de la clinique. Une archéologie du regard médical. Paris: PUF, 1963.

- The Birth of the Clinic. An Archaeology of Medical Perception. Translated by A. M. S. Smith. New York: Vintage Books, 1975.

—. Surveiller et punir. Naissance de la prison. Paris: Gallimard, 1975.

- Discipline and Punish. The Birth of the Prison. Translated by A. Sheridan. New York: Vintage Books, 1979 .

- Michel Foucault: Power/Knowledge. Selected Interviews and Other Writings, 1972-1977. Edited by C. Gordon. Brighton: Harvester Press, 1980.

_. "The Subject and Power." In Michel Foucault Beyond Structuralism and Hermeneutics, edited by H. L. Dreyfus and P. Rabinow, pp. 11-34. Chicago: Chicago University Press, 1983.

Friedrich, Hugo. Montaigne. Translated by D. Eng. Introduction by P. Desan. Berkeley: University of California Press, 1991.

Garavini, Fausta. Monstres et chimères. Montaigne, le texte et le fantasme. Paris: Champion, 1993.

Garland, Jeff, and Christina Garland. Life Review in Health and Social Care: A Practitioner's Guide. Philadelphia: Brunner-Routledge, 2001.

Giddens, Anthony. Modernity and Self-Identity. Self and Society in the Late Modern Age. Stanford: Stanford University Press, 1991.

Gide, André. Journal 1939-1949. Souvenirs. Paris: NRF, 1960.

Gilleard, Christopher, and Paul Higgs. Cultures of Ageing. Self, Citizen and the Body. Edinburgh: Pearson Education, 2000.

Goodich, Michael. From Birth to Old Age. The Human Life Cycle in Medieval Thought, 12501350. New York: University Press of America, 1989.

Goyard-Fabre, Simone. Jean Bodin (1529-1596) et sa politique philosophique. Paris: Ellipses, 1999.

Gray, Floyd. Montaigne bilingue. Le latin des “Essais." Paris: Champion, 1991.

Greenblatt, Stephen. Renaissance Self-Fashioning. From More to Shakespeare. Chicago: Chicago University Press, 1980.

Greene, Bob. Look Younger, Feel Younger, Be Younger. New York: Little Brown and Company, 2011. 
Guerrier, Olivier. Quand "les poètes feignent": "fantasie" et "fiction" dans les "Essais" de Montaigne. Paris: Champion, 2002.

Guitton, Jean-Pierre. Naissance du vieillard. Essai sur l'histoire des rapports entre les vieillards et la société en France. Paris: Aubier, 1988.

Guttmann, David. "The Life Review: An Interpretation of Reminiscence in the Aged." Psychiatry 26 (1963), pp. 65-76.

Hadot, Pierre. Exercices spirituels et philosophie antique. Paris: Etudes augustiniennes, 1981.

—. Philosophy as a Way of Life. Edited by A. I. Davidson. Translated by M. Chase. Chicago: Chicago University Press, 1995.

Han, Béatrice. Foucault's Critical Project: Between the Transcendental and the Historical. Translated by E. Pile. Stanford: Stanford University Press, 2007.

Higounet-Nadal, Arlette. Périgueux aux XIVe et XVe siècles. Etude de démographie historique. Bordeaux: Fédération historique du Sud-Ouest, 1977.

Hutcheon, Linda. The Theory and Politics of Irony. London: Routledge, 1994.

Johnson, Paul, and Pat Thane, eds. Old Age from Antiquity to Post-Modernity. London: Routledge, 1998.

Kadlec, Alison and Ana Maria Arumi. The Science of Aging Gracefully. Scientists and the Public Talk About Aging Research. American Federation for Aging Research and The Alliance for Aging Research. no publication place: Public Agenda, 2005.

Katz, Stephen. Disciplining Old Age. The Formation of Gerontological Knowledge. Charlotte: University of Virginia Press, 1996.

Kaufman, Sharon. The Ageless Self. Sources and Meaning in Later Life. Madison: University of Wisconsin Press, 1995.

Keating, Louis Clark. Etienne Pasquier. New York: Twayne Publishers, 1972.

Kenyon, Gary, E. Bohlmeijer, and W. L. Randall. Storying Later life. Issues, Investigations, and Interventions in Narrative Gerontology. Oxford: Oxford University Press, 2011.

Kirkham, Victoria, and Armando Maggi, eds. Petrarch: A Critical Guide to the Complete Works. Chicago: University of Chicago Press, 2009.

Klapisch, Christiane, and D. Herlihy. Les Toscans et leur famille: une étude du catasto florentin de 1427. Paris: Ecole des Hautes Etudes et Fondation nationale des Sciences Politiques, 1978.

Kristeller, Paul-Oskar. Studies in Renaissance Thought and Letters. Rome: Edizione di storia e letteratura, 1956 .

Lestringant, Frank. Rhétorique de Montaigne. Actes du colloque de la Société des Amis de Montaigne 14-15 décembre 1984. Paris: Champion, 1984.

Mannheim, Karl. Essays on the Sociology of Knowledge. Edited by P. Kecskemeti. London: Routledge and Kegan Paul Ltd, 1959.

Margolin, Jean-Claude. "Le 'Chant alpestre' d'Erasme: Poème sur la vieillesse." Bibliothèque d'Humanisme et Renaissance 27, 1 (1965), pp. 37-79.

Martin, L.-H., H. Gutman, and P. H. Hutton, eds. Technologies of the Self: A Seminar with Michel Foucault. Amherst, MA: University of Massachussetts Press, 1988.

Mathieu-Castellani, Gisèle. Les Thèmes amoureux dans la poésie française (1570-160o). Paris: Klincksieck, 1975 .

—. Montaigne. L'écriture de l'essai. Paris: PUF, 1988.

Mazzotta, Giuseppe. The Worlds of Petrarch. Durham: Duke University Press, 1993.

McGowan, Margaret. The Vision of Rome in Late Renaissance France. New Haven: Yale University Press, 2000.

McGushin, Edward F. Foucault's Askèsis. An Introduction to the Philosophical Life. Evanston: Northwestern University Press, 2007.

McKinley, Mary. Les Terrains vagues des 'Essais.' Paris: Champion, 1996.

- Words in a Corner. Studies in Montaigne's Latin Quotations. Lexington, Ky: French Forum, 1981.

Minois, Georges. Histoire de la vieillesse en Occident de l'Antiquité à la Renaissance. Paris: Fayard, 1987 . 
—. History of Old Age from Antiquity to the Renaissance. Translated by S. H. Tenison. Chicago: University Press of Chicago, 1989.

Montandon, Alain, ed. Ecrire le vieillir. Clermont-Ferrand: Presses de l'université Blaise Pascal, 2005.

Moody, Harry R. "Productive Aging and the Ideology of Old Age." In Productive Aging. Concepts and Challenges, edited by N. Morrow-Howell, J. Hinterlong, M. Sherraden, pp. 175-95. Baltimore: Johns Hopkins, 2001.

Morgenroth Gullette, Margaret. Declining to Decline. Cultural Combat and the Politics of the Middle. Charlottesville: University Press of Virginia, 1997.

Najemy, John M. A History of Florence, 1200-1575. Malden, MA: Blackwell, 2006.

Nakam, Géralde. Les 'Essais' de Montaigne, miroir et procès de leur temps. Témoignage historique et création littéraire. Paris: Champion, 2001.

—. Montaigne. La Manière et la matière. Paris: Champion, 2001.

Naya, Emmanuel. 'Essais' de Michel seigneur de Montaigne. Paris: Ellipses, 2006.

Nicoud, Marilyn. Les Régimes de santé au Moyen Age. Naissance et diffusion d'une écriture médicale. 2 vols. Rome: Ecole française de Rome, 2007.

Perrona, Blandine. "Que philosopher c'est apprendre à mourir, un exercice de réception." Nouveau Bulletin de la Société internationale des amis de Montaigne V, 1 (2009), pp. $7-32$.

Pouilloux, Jean-Yves. Montaigne et l'éveil de la pensée. Paris: Champion, 1995.

-. Montaigne, une vérité singulière. Paris: Gallimard, 2012.

Powell, Jason, and Azrini Wahidin, eds. Foucault and Aging. New York: Nova Science Publishers, 2006.

Quainton, Malcolm. Ronsard's Ordered Chaos: Visions of Flux and Stability in the Poetry of Pierre de Ronsard. Manchester: Manchester University Press, 1981.

__ . "Ronsard's Sonnets pour Hélène and the alternative Helen's myth," Michigan Romance Studies 15 (1995), pp. 77-97.

Quillen, Carol E. Rereading the Renaissance. Petrarch, Augustine, and the Language of Humanism. Ann Arbor: University of Michigan Press, 1998.

Quondam, Amedeo. "Questo Povere Cortegiano". Castiglione, il libro, la storia. Rome: Bulzoni, 2000.

Randall, William L., and E. McKim. Reading our Lives. The Poetics of Growing Old. Oxford: Oxford University Press, 2008.

Regosin, Richard. The Matter of my Book. Montaigne's 'Essais' as the Book of the Self. Berkeley: University of California Press, 1977.

Ricci, Teresa. "Old Age in Castiglione's Book of the Courtier." In Growing Old in Early Modern Europe. Cultural Representations, edited by Erin E. Campbell, pp. 57-73. Aldershot: Ashgate, 2006.

Richelet, Pierre. Dictionnaire françois. 2 vols. Geneva: Slatkine Reprints, 1970.

Rigolot, François. Les Métamorphoses de Montaigne. Paris: PUF, 1988.

Rouget, François. "Ronsard et la vieillesse: expérience et représentation." In C. Winn and C. Yandell, Vieillir à la Renaissance, pp. 93-105.

Rowe, John W., and Robert L. Kahn. Successful Aging. New York: Pantheon, 1998.

Saccone, Eduardo. "The Portrait of the Courtier." In Baldesar Castiglione, The Book of the Courtier, pp. 328-41.

Sapp, Stephen. "Aging in World Religions. An Overview." In T. R. Cole, R. E. Ray, and R. Kastenbaum, A Guide to Humanistic Studies in Aging. What Does It Mean To Grow Old?, pp. 129-33.

Sears, Elizabeth. The Ages of Man. Medieval Interpretations of the Life Cycle. Princeton: Princeton University Press, 1986.

Sève, Bernard. Montaigne: Des règles pour l'esprit. Paris: PUF, 2007.

Shahar, Sulamit. Growing Old in the Middle Ages. "Winter Clothes Us in Shadow and Pain." Translated by Yael Lotan. London: Routledge, 1997. 
Simmel, Georg. "The Sociology of Sociability." American Journal of Sociology 55 (1949), pp. 259-60.

Siraisi, Nancy. Arts and Sciences at Padua. The Studium of Padua before 1350. Toronto: Pontifical Institute of Medieval Studies, 1973.

—. The Clock and the Mirror. Girolamo Cardano and Renaissance medicine. Princeton: University Press, 1997.

Skenazi, Cynthia. "The Art of Aging Gracefully: Castiglione's Book of the Courtier and Montaigne's 'On Some Verses of Virgil' (Essays, III, 5)." Bibliothèque d'Humanisme et Renaissance LXX, 3 (2008), pp. 579-93.

_. "La Diversion de la vieillesse. Les ruses de Montaigne." In C. Winn and C. Yandell, Vieillir à la Renaissance, pp. 339-57.

_ _ . "Une Ecriture de la vieillesse: les 'excremens d'un vieil esprit' et la vanité montaignienne." Bibliothèque d'Humanisme et Renaissance LXVIII, 2 (2006), pp. 289-305.

—. "The Irony of the Ages of Life: Etienne Pasquier's Les Jeus Poetiques (1610)." Aging Studies. Vol. 3. "The Ages of Life": Living and Aging in Conflict?, ed. U. Kriebernegg and R. Maierhofer. Bielefeld: Transcript Verlag, 2013, pp. 147-57.

- Le Poète architecte en France. Constructions d'un imaginaire monarchique. Paris: Champion, 2003.

Small, Helen. The Long Life. Oxford: Oxford University Press, 2007.

Smith, Paul J. "Montaigne, Juste Lipse et l'art du voyage." Romanic Review 94, 1-2 (2003), pp. $73-92$.

Sohm, Philip. The Artist Grows Old. The Aging of Art and Artists in Italy, 1500-180o. New Haven: Yale University Press, 2007.

Stacey, Peter. Roman Monarchy and the Renaissance Prince. Cambridge: Cambridge University Press, 2007.

Starobinski, Jean. Montaigne en mouvement. Paris: Gallimard, 1983.

Sturm-Maddox, Sara. Ronsard, Petrarch, and the "Amours." Gainesville: University Press of Florida, 1999 .

Sweany, Suzanne Trocmé. Estienne Pasquier (1529-1615) et le nationalisme littéraire. ParisGeneva: Champion-Slatkine, 1985.

Taunton, Nina. Fictions of Old Age in Early Modern Literature and Culture. New York: Routledge, 2007.

Tetel, Marcel. "The Humanistic Situation. Montaigne and Castiglione." The Sixteenth Century Journal 10, 3 (1979), pp. 64-84.

Thane, Pat. History of Old Age in English History. Oxford: Oxford University Press, 2000.

- The Long History of Old Age. London: Thames and Hudson, 2005.

Tournon, André. "Essai et provocation dans le troisième livre." Réforme Humanisme Renaissance 21,6 (1985), pp. 12-21.

-. Routes par ailleurs. Le nouveau langage des "Essais." Paris: Champion, 2006.

Trexler, Richard. Public Life in Renaissance Florence. New York: Academic Press, 1980.

Troyansky, David. Old Age in the Old Regime. Image and Experience in 18th-Century France. Cornell: Cornell University Press, 1989.

Vernant, Jean-Pierre. Entre mythe et politique. Paris: Seuil, 1996.

Vernant, Jean-Pierre, and Marcel Détienne. Les ruses de l'intelligence. La mètis des Grecs. Paris: Flammarion, 1974.

Weber, Max. The Theory of Social and Economic Organization. Translated by A.-M. Henderson and T. Parsons. New York: Free Press, 1947.

Weil, Andrew. Health by Aging. A Lifelong Guide to your Physical and Spiritual Well-Being. New York: Knopf, 2005.

Winn, Colette H., and C. Yandell, eds. Vieillir à la Renaissance. Paris: Champion, 2009.

Wittengstein, Ludwig. Philosophical Investigations. Oxford: Oxford University Press, 1968.

Woodward, Kathleen. At Last, the Real Distinguished Thing: The Late Poems of Eliot, Pound, Stevens, and Williams. Columbus, Ohio: Ohio State University Press, 1980. 
"Telling Stories: Aging, Reminiscence, and the Life Review." Journal of Aging and Identity 2, 3 (1997), pp. 149-63.

Zak, Gurk. Petrarch's Humanism and the Care of the Self. Cambridge: University Press, 2010.

\section{Internet Resources}

http://beliefnet.com/Holistic-Living/index.aspx. Accessed March 14, 2013.

Château d'Yquem: www.yquem.fr. Accessed March 14, 2013.

Gallup poll: http://www.gallup.com/poll/127514/Americans-Projected-Retirement-Age-Con tinues-Creep-Up.aspx?utm_source $=$ tagrss\&utm_medium $=$ rss\&utm_campaign $=$ syndication\&utm_term=All\%20Gallup\%2oHeadlines. Accessed March 14, 2013.

ABC News Radio: http://abcnewsradioonline.com/business-news/young-people-struggleto-find-jobs-while-elders-hold-on-long.html\#ixzz26CewVYC3. Accessed March 14, 2013.

World Health Organization: http://www.who.int/about/definition/en/print.html. Accessed March 14, 2013. 


\section{INDEX}

Aphorisms (Hippocrates) 20, 39, 47

Aristotle 10, 16, 21, 25-26, 31, 40-41, 46, 81, $82 \mathrm{n} 27,84,88 \mathrm{n} 39,126,158$

Augustine, saint $\quad 74-75,103-104,119$

Bacon, Francis 12

Baïf, Jean-Antoine de 120, 129, 166n61

Binet, Claude 106-108, 110

Bodin, Jean $\quad 87-89,95$

Book of the Courtier (Castiglione) 13, 64, $79-85,87,95,112,114,116,118,124$

Bracciolini, Gian Francesco 124

Cardano, Girolamo 11, 37, 51-53

Carmen Alpestre (Erasmus) 46-47, 55, 146

Castiglione, Baldassare $\quad 7,13,64,79-86$, 95, 105, 106n17, 111-112, 114, 116, 118, 124, 126

Charron, Pierre 164

Cicero $7,10,22,25-27,43^{-45}, 56,63^{-64}$, $67,70-71,73-75,78-79,81,83-84,87,89$, $92,94-95,103,116,126,128,144,15^{1-152}$, $158,163-164 n_{53}$

Clermont, Catherine de $\quad 120,122-123,127$, 129

Cornaro, Luigi $\quad 7,13,16,36-45,47-48$, $5^{1-54,59-6 o, ~ 82 n 28, ~ 87 n 37 ~}$

Della vita sobria (Cornaro) 36-37, 40, $42-43,45,5^{1}$

De Remediis utriusque fortunae (Petrarch) 65, 77-79

De Sanitate tuenda (Galen) 16n4, 17-18, 20-21, 23, 37-38, 47, 51-52, 141

De Senectute (Cicero) 7, 10, 27, 43-46, 56, $63-64,67,70-74,79,81,83-84,87,89$, 92-95, 116, 152, 158-159, 163, 164n 53

De Vita libri tres (Ficino) 28, 30, 35, 166

Du Bellay, Joachim 131-132, 160

Du Laurens, André 53

Du Perron, Jacques Davy 106, 109

Erasmus $7,13,16,42-48,55,58-59,63$, 139, 142, 144-150, 152, 158, 159n40-41, 166

Essais (Montaigne) $3-4,13,48-49,56,59$, $64,87,89,91,93-94,111 n 36,112$, 113n4o, $115,118,139,15^{0-156,158 n 39, ~ 159 n 4 o, ~}$ 16o-164, 166
Ficino, Marsilio $\quad 7,13,16,28-33,35^{-}-37,40$, $44,55,59,111,165,166 n_{5} 8$

Foucault, Michel $\quad 5^{-8,15}, 20,21 n 12,23^{-24}$, 26, 27n28, 29, 36, 41, 50, 58-59, 62, 68, 99, $130,138,147-148,150,153^{-155}, 157$

Furetière, Antoine $\quad 120,163$

Galen $\quad 16-24,26,28,31,33-35,37-39,41$, $43,47,50,52-54,59,66,73,140-141,143$, 165

Gerontocomia (Zerbi) 28-29, 33-34, 36, $5^{1}$

Goulart, Simon 11, 89, 137

Guicciardini, Niccolo 92, 137

Guido da Vigevano 22

Hippocrates $17,20,22,23 n 21,25,28-29$, $39,47,53,59,63$

Horace $50,75,15^{2}$

Isidore of Seville $\quad 23,31$

Jeus Poétiques (Pasquier) 119, 129-136

Joubert, Laurent $\quad 51-53,55,87-88,89 n 40$, 95,166

Journal de voyage en Italie (Montaigne) 160

La Porte, Maurice de $\quad 163$

Letters of Old Age (Petrarch) 3, 10-11, 22-27, 30, 36, 64-75, 77, 79, 95-96, 102, 153

Letters on Familiar Matters (Petrarch) 3, 11, 27n3o, 64, 75

Libro del Cortegiano (Castiglione) see Book of the Courtier

Machiavelli, Niccolo 92

Marcus Aurelius $\quad 40,150$

Monluc, Blaise de $\quad 11,87,89,95$

Montaigne, Michel de $1-4,7-11,13,15^{-17}$, 40, 42, 45, 47-6o, 64, 86-87, 89-97, 100, 111-120, 135-139, 141, 148, 150-166

Old Men's Chat (Erasmus) 139, 142, 144-149, 15on21

Pasquier, Etienne $\quad 7,11,13,100,119-137$ 
Pastorale du vieillard amoureux

(Pasquier) 119-123, 126-129, 133

Petrarch, Francesco $1-4,7-11,13,15^{-17}$, $22-28,30,36,40,44,47-48,58-60$,

64-77, 79, 95-97, 100, 101n8, 102-103, 104, n13-14, 105, 107-108, 109n31, 111, 131-134, 136-139, 141, 148, 151-154, 166

Plato $10,25^{-27}, 29,3^{2 n} 39,44,57,63,81$, $83,87-88,113-114,151,15^{8}$

Plutarch 25n25, 83-84, 87, 93, 151, 154, 162

Popular Errors (Joubert) 51-52, 89n4o, 166n 59

Praise of Folly (Erasmus) 13, 16, 43-44, 46, 58-59, 158, 159n41
Rerum Familiarium Libri (Petrarch) see Letters on Familiar Matters

Rerum Senilium Libri (Petrarch) see Letters of Old Age

Rerum Vulgarium Fragmenta, Rime Sparse (Petrarch) 3, 13, 100-105, 107, 151, 153

Ronsard, Pierre de 7,13,100, 105-111, 119, $124 \mathrm{n} 57,127,130-137$

Secretum (Petrarch) 3, 100, 103, 151, 153 Seneca $27,36,60,70-71,73-75,79,103$, $115,146,15^{1-152}$

Sonnets pour Hélène (Ronsard) 105-109, $124,133-134$

Zerbi, Gabriele $\quad 7,13,16,28-29,33-37,40$, $44,51,55,59$ 